\author{
Universidade de São Paulo \\ Faculdade de Filosofia, Letras e Ciências Humanas
}

Fábio Cereda Cordeiro

\title{
O FMI, a política interna dos EUA e a crise da dívida dos anos 80
}

São Paulo

2010 


\section{Fábio Cereda Cordeiro}

\section{O FMI, a política interna dos EUA e a crise da dívida dos anos 80}

Tese apresentada à Faculdade de Filosofia, Letras e Ciências Humanas da Universidade de São Paulo para obtenção do título de Doutor em Ciência Política.

Área de concentração: Relações Internacionais Orientador: Prof. Dr. Rafael Antonio Duarte Villa

São Paulo

2010 


\section{Folha de aprovação}

Fábio Cereda Cordeiro

O FMI, a política interna dos EUA e a crise da dívida dos anos 80

Tese apresentada ao Departamento de Ciência Política da Faculdade de Filosofia, Letras e Ciências Humanas da Universidade de São Paulo para obtenção do título de Doutor.

Área de Concentração: Relações Internacionais

Aprovado em:

\section{Banca Examinadora}

Prof. Dr. Rafael Antonio Duarte Villa (Orientador)

Instituição: DCP/USP

Assinatura:

Prof. Dr.:

Instituição:

Assinatura:

Prof. Dr.:

Instituição:

Assinatura:

Prof. Dr.:

Instituição:

Assinatura:

Prof. Dr.:

Instituição: Assinatura: 
Para Patrícia 


\section{Agradecimentos}

Ao Professor Rafael Villa, pela orientação dedicada e paciente, pelo apoio permanente, pela amizade e por sempre exigir de mim um pouco mais do que eu mesmo julgava capaz de fazer.

À Professora Maria Hermínia Tavares de Almeida, por me inspirar, desde as primeiras semanas da Graduação em Relações Internacionais, a seguir este caminho.

Aos professores Amâncio Jorge de Oliveira, Carlos Eduardo Ferreira de Carvalho, João Paulo Candia Veiga e Maria Hermínia Tavares de Almeida pela participação nos dois exames de qualificação. Seus comentários, críticas e sugestões foram fundamentais para o direcionamento desta pesquisa.

Aos funcionários do Departamento de Ciência Política da USP, Maria Raimunda dos Santos, Márcia Regina Gomes Stacks, Ana Maria Capel, Vivian Pamela Viviane e Leonardo Novaes, sempre dedicados e bem-humorados.

Aos colegas do Núcleo de Pesquisa em Relações Internacionais da USP, em particular a Flavio Azevedo e Juliana Viggiano, co-editores da Carta Internacional, pelo apoio e compreensão.

Aos amigos da USP, em particular a Nadim Gannoun, André Ponce, Ricardo Rizzo e Manoel Galdino, pela amizade e pelas conversas sempre ricas.

Aos meus chefes na Coordenação-Geral de Assuntos de Estados Unidos e Canadá do Ministério das Relações Exteriores, João Tabajara de Oliveira Jr. e Carlos Henrique Moojen de Abreu e Silva, pelo incentivo e pelo interesse em minha pesquisa, e aos colegas da embaixada do Brasil em Washington Fátima Ishitani e Marcos Henrique Sperandio, pelo apoio na obtenção de documentos.

Aos meus pais, Florisvaldo e Clara, cuja dedicação e apoio incondicionais me permitiram realizar esse sonho.

A Patrícia Leal, com muito amor, por compartilhar tudo comigo e por respeitar minhas escolhas.

Ao CNPq, pelo auxílio financeiro que possibilitou dar início a esta pesquisa.

In memoriam ao Professor Gildo Marçal Brandão, com profunda admiração, pelo exemplo de dedicação à atividade intelectual. 


\section{Resumo}

Esta pesquisa investiga os fatores de política doméstica que motivam os Estados a delegar determinados temas a organizações internacionais. Com base na abordagem de principal-agente aplicada à delegação internacional, o estudo de caso sustenta que a dinâmica da política doméstica norte-americana foi um determinante importante da delegação da crise da dívida dos anos 80 para o Fundo Monetário Internacional. A hipótese se baseia no argumento teórico segundo o qual a delegação de um tema para uma organização internacional oferece ao ator que delega (em geral o Poder Executivo) uma oportunidade de aumentar sua influência sobre aquele tema em detrimento dos outros atores políticos domésticos. Nesta visão, a delegação pode aumentar a influência do Poder Executivo ao deslocar o poder de agenda sobre o tema para a organização internacional, reduzir o número de pontos de decisão doméstica, criar assimetrias de informação e prover fontes adicionais de legitimidade para as posições do Executivo. Quanto mais agudo for o conflito doméstico sobre um tema, maior será o incentivo para o Poder Executivo delegá-lo a uma organização internacional.

Este estudo sustenta que a crise da dívida dos anos 80 foi essencialmente uma crise bancária, e como tal poderia ter sido tratada exclusivamente no nível doméstico norteamericano. A pesquisa apresenta evidências de que, ao enquadrar a crise como um problema de política internacional e delegá-la ao FMI, o Departamento do Tesouro dos EUA aumentou seu controle sobre o tema e reduziu a influência do Congresso, cujas visões e prioridades eram diferentes das do governo. O Executivo norte-americano, a despeito da desconfiança que inicialmente nutria com relação às instituições financeiras multilaterais, decidiu delegar o gerenciamento da crise para o FMI porque suas preferências estavam mais alinhadas com as preferências do Fundo do que com as preferências do Congresso e, portanto, as perdas de agências eram pequenas em comparação com o ganho obtido por impedir o Congresso de adquirir um papel ativo sobre a questão.

Palavras-chave: crises financeiras; organizações internacionais; Estados Unidos; FMI; política externa dos EUA. 


\section{Abstract}

This research examines the domestic factors that contribute to certain political issues being delegated by states to international organizations. Based upon principal-agent theory, the case study argues that American domestic politics played a major role in the delegation of the 1980's debt crisis of developing countries to the International Monetary Fund. The hypothesis is based on the theoretical argument that delegation of an issue to an international organization offers the delegating actor (usually the executive branch) an opportunity to increase its influence on that issue vis-à-vis other domestic political actors. As such, delegating an issue to an international organization can increase the influence of the executive branch by shifting control of the agenda on the issue in favor of the delegating actor, decreasing the number of domestic decision points, creating information asymmetries and providing additional sources of legitimacy for the positions of the executive. The more intense the domestic conflict on an issue, the bigger the incentive for the executive branch to delegate the issue to an international organization.

This study contends that the LDC debt crisis of the 1980's was essentially a banking crisis, and that as such could have been handled domestically by the US government. The research provides evidence that, by framing the crisis as an international problem and delegating it to the IMF, the US Department of the Treasury increased its control of the issue and reduced the influence of Congress, whose views and priorities were different from those of the Administration. The US Treasury, despite its initial mistrust of international financial institutions, chose to delegate the management of the crisis to the IMF because US Treasury preferences were more aligned with the preferences of the Fund than with the preferences of Congress, and thus agency losses were small in comparison with what was gained by preventing Congress from having an active role on the issue.

Keywords: financial crises; international organizations; United States; IMF; American foreign policy. 


\section{Sumário}

1. INTRODUÇãO 1

1.1 A crise da dívida como uma crise financeira internacional................................... 3

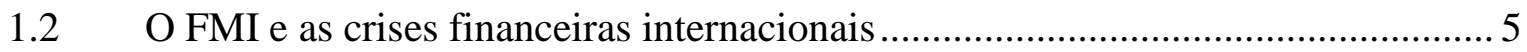

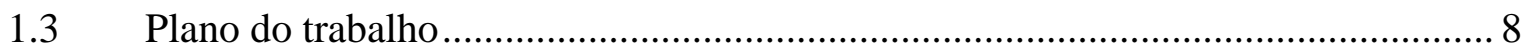

2. ABORDAGEM TEÓRICA 10

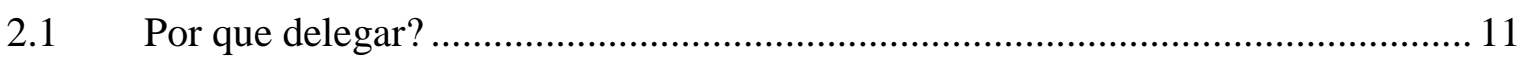

2.1.1 O problema do controle do agente ....................................................... 12

2.1.2 Particularidades da delegação para organizações internacionais ............ 15

2.1.3 Organizações internacionais como agentes ......................................... 17

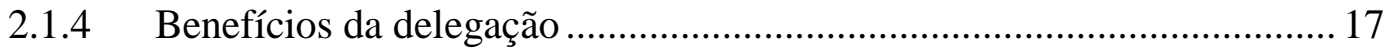

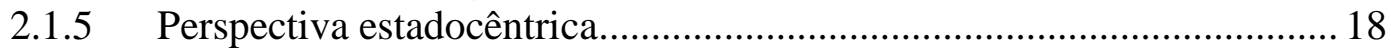

2.1.6 Perspectiva de política doméstica ............................................................ 24

2.2 A delegação da crise da dívida dos anos 80 para o FMI .................................... 33

2.2.1 Explicações oferecidas pela literatura ................................................... 35

2.2.2 Uma nova explicação: política doméstica dos EUA como determinante

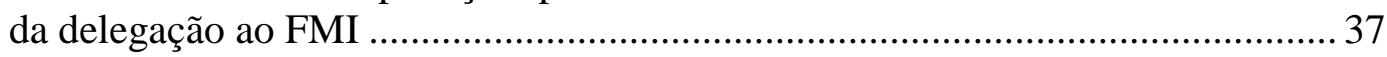

3. AtORES INSTITUCIONAIS 42

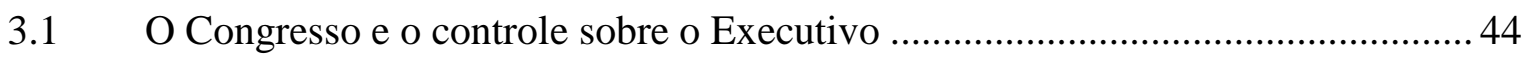

3.1.1 O papel do Congresso em política externa........................................... 47

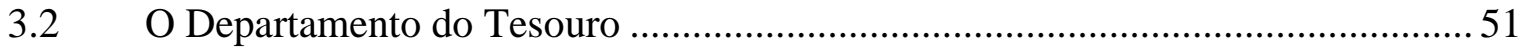

3.2.1 Exchange Stabilization Fund .......................................................... 51

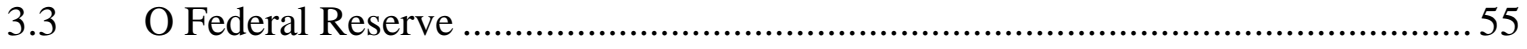

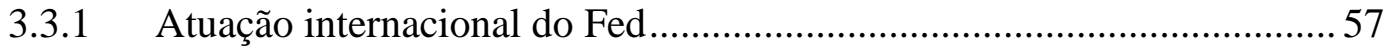

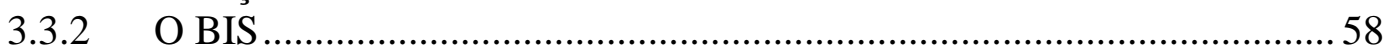

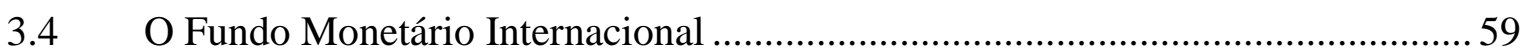

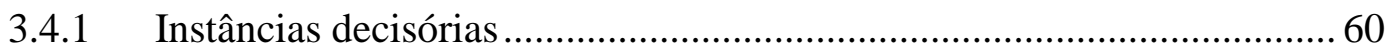

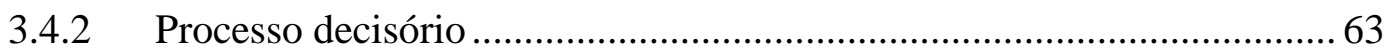

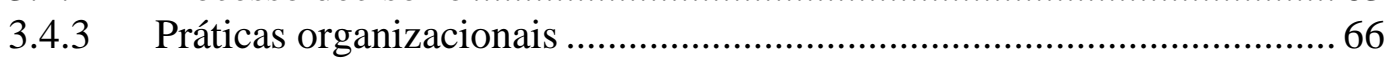

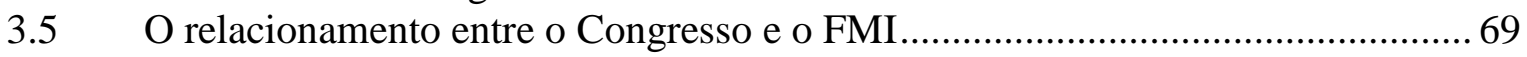

\begin{tabular}{lll}
4. & A CRISE DA DÍVIDA & 73 \\
\hline
\end{tabular}

4.1 Antecedentes e contexto político da crise da dívida............................................. 74

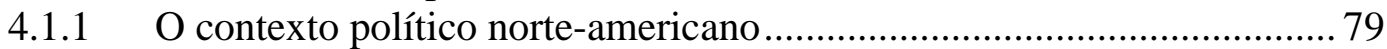

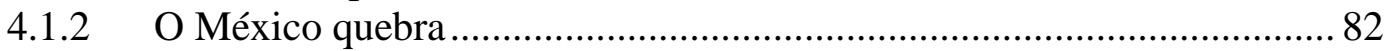

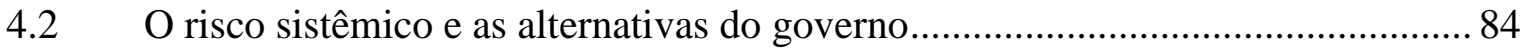

4.2.1 O governo dos EUA monta o pacote.......................................................... 86

4.2.2 Algumas conclusões preliminares ...................................................... 91

4.3 Outras respostas bilaterais à crise: Argentina e Brasil .......................................... 95

4.4 A resposta multilateral: o FMI e a conferência de Toronto ................................. 102

4.4.1 A desconfiança do governo Reagan com relação ao FMI..................... 102

4.4.2 A Conferência de Toronto ................................................................. 104 
4.4.3 A crise chega ao Congresso ……………………………………........ 110

4.4.4 O FMI assume o comando ……………………………………….... 117

4.4.5 A Estratégia dos Cinco Pontos …………………………………….... 121

5. A AMPLIAÇão DO CAPITAL DO FMI NO CONGRESSO

5.1 O contexto político e a estratégia do governo ………………………………........ 127

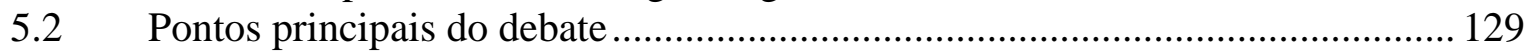

5.3 A tramitação do projeto de lei ............................................................................... 141

5.4 Conclusão ……………………………………………………………… 147

6. O Plano Baker 149

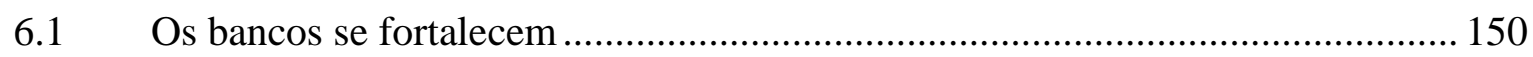

6.2 Os devedores pagam a conta …………………………………………… 156

6.3 A mobilização do Congresso ............................................................................. 163

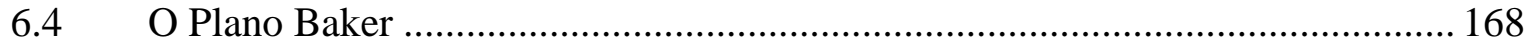

6.4.1 Banco Mundial: protagonista ou coadjuvante? ……………………..... 172

6.5 Resultados: o Congresso e o Plano Baker .......................................................... 178

6.5.1 Nível externo: resultados decepcionantes e nova crise do México....... 179

6.5.2 Nível doméstico: sucesso em capturar a iniciativa política..................... 182

6.5.3 A associação entre crise da dívida e déficit comercial no Congresso ... 185

\begin{tabular}{ll} 
7. O Plano BRADY & 191 \\
\hline
\end{tabular}

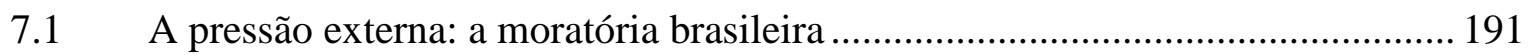

7.2 A pressão doméstica: o ativismo do Congresso ……………………………....... 199

7.3 O FMI e as negociações com Argentina, Brasil e México .....................................2 219

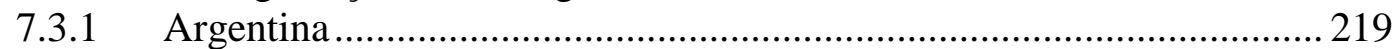

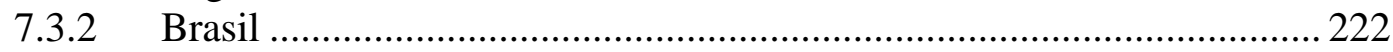

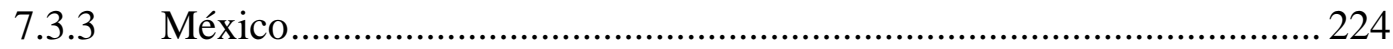

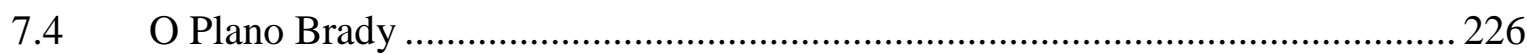

7.4.1 A reação ao Plano Brady no Congresso ................................................... 234

7.4.2 A aprovação do Plano pelo FMI ......................................................... 238

7.4.3 O pacote do Plano Brady para o México............................................... 239

7.5 O aumento do capital do FMI.......................................................................... 242

8. CONCLUSÃo $\quad 245$

8.1 A crise da dívida: uma crise bancária norte-americana....................................... 246

8.1.1 Emprestadores de última instância: Tesouro e Fed ................................. 247

8.2 A solução de longo prazo: o FMI ................................................................. 248

8.2.1 Vantagens da delegação ao FMI ......................................................... 248

8.2.2 Custos da delegação ...................................................................... 252

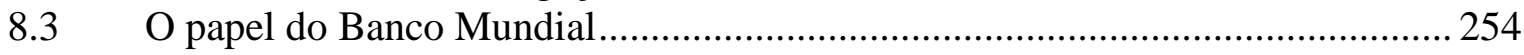

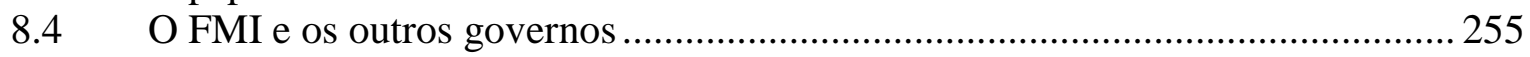

$\begin{array}{lr}\text { REFERÊNCIAS } & 257\end{array}$

ANEXO: ORIGINAIS EM INGLÊS DAS PRINCIPAIS CITAÇÕES 


\section{Introdução}

Uma das características mais marcantes do sistema internacional montado a partir do final da Segunda Guerra Mundial é a quantidade e importância das organizações internacionais. Entidades como ONU, OTAN, OEA, União Européia, OMC, OCDE, FMI e Banco Mundial têm um papel de destaque na estrutura da governança global, atuando em uma enorme gama de assuntos. Organizações menos conhecidas, como a OACI, a UIT e a OMI ${ }^{1}$ são instrumentos essenciais de regulação e coordenação internacional em suas respectivas áreas de atuação.

A despeito do papel central que ocupam no cenário contemporâneo, as organizações internacionais não são entes cuja existência independe dos Estados nacionais. Ao contrário, são os Estados que criam essas organizações e a elas delegam determinados temas da agenda internacional.

Uma organização internacional (OI) é uma associação entre sujeitos de Direito Internacional e que também goza de personalidade jurídica internacional. A definição exclui, portanto, organismos que são meros órgãos de uma OI, como a Corte Internacional de Justiça, tratados multilaterais sem personalidade jurídica, como o GATT, ou empresas instituídas por compromisso entre Estados, como a Itaipu Binacional. Dois órgãos são apontados como essenciais para a estrutura de toda organização internacional: uma assembléia geral, onde todos os Estados-membros têm voz e voto, e uma secretaria, o órgão de administração permanente (Rezek, 2002, p. 240-242)

A delegação de uma tarefa a uma organização internacional implica em custos para os Estados-membros. No mínimo, há o custo financeiro de manter a secretaria. Para além disso, há o custo derivado do fato que a delegação de um tema a uma OI reduz a autonomia dos Estados para tratar desse tema. Diretivas da OACI, por exemplo, devem ser aplicadas em todos os aeroportos dos países-membros, não importando se implicam em custos adicionais para os operadores ou usuários. Resoluções do Conselho de Segurança das Nações Unidas devem ser obedecidas por todos os países-membros da ONU. O aumento da jurisdição da União Européia criou o problema do "déficit democrático", causado pela perda de autonomia

\footnotetext{
${ }^{1}$ As siglas referem-se a, respectivamente, Organização da Aviação Civil Internacional, União Telegráfica Internacional e Organização Marítima Internacional.
} 
dos Estados europeus para legislar sobre grande variedade de assuntos, transferidos à jurisdição comunitária.

Por que, então, os Estados delegam tarefas a organizações internacionais? A literatura geralmente atribui a proliferação de organizações internacionais ao fato de que elas aumentam o sucesso e a efetividade da cooperação entre Estados e resolvem problemas de coordenação internacional. O Conselho de Segurança da ONU é um fórum permanente que permite que os Estados que o integram busquem soluções pacíficas para situações que ameacem a paz e a segurança internacionais; a OMC estabelece regras de liberalização comercial e cria sanções para os Estados que as infringirem; o FMI agrega recursos de seus Estados-membros e os utiliza para ajudar países com problemas de balança de pagamentos a reequilibrar suas contas externas; a UIT estabelece padrões que permite a integração dos diversos sistemas nacionais de telecomunicações.

A base destes argumentos é que as organizações internacionais oferecem, aos Estados que as criam e mantêm, vantagens que compensam seus custos. Estas explicações, portanto, partem do pressuposto analítico de que os Estados são atores unitários e racionais.

Este trabalho propõe um estudo sobre a delegação a organizações internacionais, abandonando o pressuposto do Estado como ator unitário e racional. Como resultado, defende que a delegação de temas e tarefas a OIs tem um importante componente doméstico, pois ela é uma forma de retirar determinados problemas da esfera da política interna dos Estados e permitir que burocracias do Poder Executivo tratem delas com um mínimo de interferência de outros atores, especialmente do Poder Legislativo.

Como forma de verificar a validade desta proposição, o trabalho apresenta uma análise da delegação da gestão da crise da dívida dos anos 80 para o Fundo Monetário Internacional. Esta tarefa poderia ter sido realizada unilateralmente pelos Estados Unidos, ou coordenada por um acordo ad hoc entre os países industrializados. No entanto, o governo dos EUA preferiu delegá-la ao FMI. Este trabalho buscará mostrar que um importante componente que levou à delegação da gestão da crise para o FMI foi o interesse do Poder Executivo norteamericano de minimizar a influência do Congresso sobre a questão, aumentando sua autonomia para conduzir a política sobre o tema. 


\subsection{A CRISE DA DÍVIDA COMO UMA CRISE FINANCEIRA INTERNACIONAL}

Quando o ministro da Fazenda do México, Jesús Silva Herzog, viajou para Washington em agosto de 1982 e informou ao governo norte-americano que seu país não tinha mais condições de manter o serviço de sua dívida externa, encerrou-se o ciclo de quase uma década de dinheiro farto e barato para os países do Terceiro Mundo e iniciou-se uma crise que durou quase dez anos e que colocou em risco a estabilidade do sistema financeiro internacional.

Este trabalho enxerga a crise da dívida dos anos 80 como um episódio típico de crise financeira, segundo descrito por Charles Kindleberger (2000):

O que acontece, basicamente, é que alguns acontecimentos mudam o panorama econômico. Novas oportunidades de lucros são aproveitadas até o exagero, de uma forma tão próxima à irracionalidade que se transforma em mania. Quando a alta se torna excessiva, o sistema financeiro passa por um tipo de "aflição", no curso da qual a corrida para reverter o processo de expansão pode tornar-se tão precipitada que se assemelha a pânico. Na fase maníaca, pessoas ricas ou com crédito transformam seus bens em dinheiro ou tomam empréstimos para comprar ativos financeiros reais ou ilíquidos. No pânico, ocorre o movimento inverso, de ativos financeiros ou reais para dinheiro, ou reembolso de débito (2000, pp. 3-4).

A crise financeira que atingiu os países em desenvolvimento a partir de 1982 foi o resultado de um movimento especulativo de concessão de crédito a tomadores soberanos que começou no início dos anos 70 , com o primeiro choque do petróleo. O súbito aumento do preço do petróleo permitiu aos países exportadores obter expressivos superávits comerciais e acumular grandes volumes de reservas em dólares, enquanto os países consumidores amargaram déficits sucessivos que precisavam ser financiados. A partir de então, as operações internacionais de crédito para tomadores soberanos explodiram, caracterizando uma verdadeira bolha financeira. Os lucros dos grandes bancos nas operações internacionais causaram um verdadeiro "efeito manada", no qual o interesse individual de cada banco era emprestar grandes volumes de recursos, independentemente do risco objetivo dos tomadores, para manter um nível de lucratividade similar à dos outros bancos que estavam no mesmo mercado.

Como em toda mania, fatores externos interromperam a alta e deram origem ao processo que culminou em pânico. Em 1979, o mercado internacional recebeu dois golpes muito duros: o segundo choque do petróleo e o súbito aumento das taxas de juros dos Estados Unidos, empreendido pelo banco central norte-americano para conter a inflação. A partir de então, o endividamento dos países em desenvolvimento subiu de forma explosiva, até que os 
bancos privados começaram a considerar o risco desses tomadores como excessivamente elevado. Quando, em meados de 1982, o México encontrou dificuldades para levantar dinheiro no mercado internacional, sobreveio o pânico: subitamente, os bancos credores perceberam que seus clientes do Terceiro Mundo não eram mais capazes de manter os pagamentos de juros e amortizações.

A insolvência dos países devedores representou risco iminente a todo o sistema financeiro norte-americano. O volume dos empréstimos dos grandes bancos aos países em desenvolvimento era maior do que o capital destas instituições — portanto, um default de alguns países devedores levaria diversos bancos à insolvência. O simples risco de insolvência poderia causar uma corrida aos bancos e levar o sistema financeiro norte-americano ao colapso, o que, por sua vez, causaria fortíssima contração econômica.

Confrontado com uma crise, o Estado tem duas alternativas: manter-se afastado, esperando que o mercado ajuste-se naturalmente, ou intervir, injetando liquidez no sistema. Economistas da corrente monetarista defendem que, confrontado com uma crise, é melhor que o Estado não intervenha, pois sua intervenção apenas torna a crise mais grave (Kindleberger, 2000, cap. 9). Como afirma Kindleberger, a prática da política financeira dos últimos três séculos tem mostrado que, num episódio de crise financeira, faz-se necessária a intervenção de um ator que forneça liquidez adicional e evite o colapso - um emprestador de última instância. Este ator é o Estado, que provê o bem público da estabilidade (idem, 1973).

Em agosto de 1982, as autoridades monetárias norte-americanas tinham algumas opções à sua disposição. A primeira era não intervir e deixar que os bancos comerciais sofressem as consequiências de uma década de euforia financeira e de empréstimos pouco prudentes. Sobreviria a quebra de diversos bancos — inclusive alguns dos maiores - e provavelmente uma recessão. Findo o episódio, segundo a visão dos conservadores norteamericanos, o sistema estaria mais saudável, pois teria punido a incompetência e purgado os banqueiros menos cautelosos. Por isso, esta era a opção preferencial dos conservadores, que formavam a base política do presidente Ronald Reagan.

A segunda opção era injetar liquidez no sistema. Isto poderia ser feito de várias formas. O governo poderia inicialmente acionar a janela de desconto, oferecendo recursos no mercado aberto para os bancos. Poderia comprar os ativos "podres" dos bancos (os empréstimos realizados para os países em desenvolvimento) a um valor próximo ao valor de face. Aqueles bancos que se mostrassem insolventes poderiam ser nacionalizados ou 
comprados por outros bancos com fundos emprestados pelo Federal Reserve. Por fim, os bancos que viessem a falir teriam seus depósitos garantidos pela Federal Deposit Insurance Corporation, o que minimizaria os prejuízos para os pequenos depositantes. Como se sabe, todas essas opções foram utilizadas pelo governo norte-americano como respostas à crise financeira de 2008. Sabe-se também que essa opção custou muito caro ao governo, tanto do ponto de vista fiscal - em termos de aumento explosivo do déficit e da dívida pública quanto do ponto de vista político - em função do desgaste causado pela percepção de que as autoridades estavam apenas "salvando" os banqueiros e deixando ao desamparo o cidadão comum, que não tinha responsabilidade alguma no episódio.

Entre 1982 e 1990, o governo dos presidentes Reagan e Bush também injetou liquidez no sistema - mas de uma forma mais sutil. Em vez de oferecer recursos diretamente para os grandes bancos, o governo norte-americano ajudou a financiar os países devedores e fez com que eles continuassem pagando os juros e as amortizações de suas dívidas aos credores. Gradativamente, os bancos privados lograram reduzir a parcela de seu capital comprometida com empréstimos aos seus clientes do Terceiro Mundo, até que o risco de quebra e crise sistêmica foi dissipado.

Isso foi feito a despeito da forte oposição, no Congresso norte-americano, a operações de salvamento dos bancos, tanto por parte da base conservadora (cada vez maior e mais vocal) quanto por parte dos liberais. Ademais, a injeção de liquidez do sistema foi feita de forma a minimizar as perdas para o setor financeiro, transferindo a maior parte dos custos do ajuste para os países devedores e para os setores agrícola e industrial norte-americanos.

Como tal manobra foi possível? Este trabalho propõe que o elemento que viabilizou politicamente a operação de salvamento organizada pelo governo norte-americano foi o Fundo Monetário Internacional, ao qual a gestão da crise foi delegada.

\subsection{O FMI E AS CRISES FINANCEIRAS INTERNACIONAIS}

Criado em 1944, na Conferência de Bretton Woods, o FMI nasceu com a função de financiar déficits temporários em conta corrente e fiscalizar o cumprimento das regras que compunham o regime estabelecido na Conferência (Boughton, 1997, p. 9). A organização, portanto, não possuía recursos suficientes para estabilizar o sistema financeiro durante uma crise em larga escala. Prova disso é que a grande crise do imediato pós-guerra e a ameaça de 
expansão soviética levaram os Estados Unidos a montar e administrar, unilateralmente, um grande projeto de reconstrução da Europa — o Plano Marshall.

A partir do Plano Marshall, o FMI assumiria uma posição discreta, sendo raramente acionado por seus Estados-membros. Sua atuação em seus primeiros anos era tão pouco relevante que uma das críticas mais comuns dirigidas à instituição à época era o fato de que a ausência de algo importante a realizar a levara a voltar-se para tarefas "acadêmicas" como coletar dados macroeconômicos e publicar papers como forma de justificar os altos salários de seus funcionários (Kindleberger, 1951, pp. 40-42). Somente em 1956, em virtude da crise de Suez, o FMI envolveu-se numa operação de maior monta, emprestando recursos para Egito, França, Grã-Bretanha e Israel. Ainda assim, a crise de Suez não ofereceu um grau de risco sistêmico suficiente para que se pudesse ver o FMI como o estabilizador do sistema financeiro internacional. De fato, em situações de crise subseqüentes, nas quais o risco sistêmico foi bem mais elevado (o colapso do ouro em 1968 e o colapso de Bretton Woods entre 1971 e 1973), o FMI teve papel secundário, pois os Estados mais ricos assumiram diretamente a tarefa de estabilização (Boughton, 1997, pp. 10-16). Nos anos 70, a instituição mais uma vez se tornaria quase irrelevante, já que, nos países desenvolvidos, o sistema de taxas de câmbio fixo de Bretton Woods foi substituído por um sistema de taxas flutuantes, enquanto que os países em desenvolvimento passaram a se financiar diretamente junto aos bancos privados. Ao FMI, restou o papel de emprestador de recursos para os países mais pobres (Cohen, 1982).

A partir da crise da dívida de 1982, o papel do FMI mudou. Os Estados Unidos delegaram ao Fundo a função de gerenciar sua estratégia de estabilização do sistema financeiro internacional. Nos anos seguintes, a despeito da crescente oposição doméstica a essa estratégia, os Estados Unidos mantiveram seu apoio à instituição.

O papel de gerente de crises financeiras foi reforçado nos anos 90. Quando irrompeu a crise mexicana, no final de 1994, os Estados Unidos mais uma vez delegaram a tarefa de estabilizar o sistema financeiro internacional ao FMI (Boughton, 1997, p. 21). A entidade assumiria o mesmo papel em ocasiões posteriores, como as crises russa, asiática e brasileira. Em todas elas, contou com apoio dos Estados Unidos.

Uma crise financeira - como a crise da dívida dos anos 80 ou as crises mexicana e asiática dos anos 90 - é uma ameaça ao regime monetário internacional. Manter um regime em funcionamento pode ser entendido como o fornecimento de um bem público, ou seja, um 
bem que, uma vez provido, pode ser usufruído por todos os atores do sistema. No caso do regime financeiro internacional, o bem público é a estabilização do sistema financeiro internacional, necessária para manter o regime em funcionamento. Neste caso, existe claramente um hegemon - os Estados Unidos - que, por sua posição privilegiada de emissor da moeda de reserva internacional, assume os custos do provimento do bem público representado pela estabilidade do sistema.

Tanto nas crises dos anos 80 quanto nas crises dos anos 90, os recursos usados para a estabilização do sistema financeiro internacional foram fornecidos principalmente pelos Estados Unidos. Os EUA, em tese, poderiam ter gerenciado as crises financeiras dos anos 80 e 90 de forma unilateral, podendo assim impor totalmente seus termos. Ao delegar esta tarefa a uma organização internacional, o governo americano abriu a possibilidade de ela não fosse executada exatamente como gostaria. Por que, então, preferiu delegar a gestão desta crise a administrá-las diretamente, ou no máximo por intermédio de instituições ad hoc como o Clube de Paris ou o G-7, onde sua influência deveria ser maior?

Em virtude do caráter incipiente dos trabalhos sobre delegação, a pergunta proposta neste trabalho tem sido objeto de poucos estudos sistemáticos. Duas hipóteses mais comuns podem ser encontradas para explicá-la. A primeira é que o Fundo, por seu caráter "técnico" e "neutro", teria mais legitimidade para impor condições aos países em desequilíbrio de balança de pagamentos (Swedberg, 1986), pois sua atuação não seria vista como interferência dos países ricos nos assuntos internos dos países devedores. O argumento se baseia no fato de que os empréstimos do FMI são invariavelmente condicionados à adoção, por parte do país em dificuldades, de ajustes econômicos que vão desde desvalorizações cambiais e cortes de gastos públicos até reformas econômicas profundas como privatizações e desregulamentação de mercados. Por isso, é mais fácil para estes países aceitarem programas de ajustes impostos por uma burocracia internacional (pretensamente neutra do ponto de vista político) do que por um outro Estado. Os EUA, reconhecendo este fato, delegariam esta função ao FMI para maximizar a cooperação por parte dos países devedores.

A segunda hipótese é que o FMI, ao agrupar os recursos dos países industrializados e contar com um corpo técnico qualificado, seria mais eficiente na alocação de recursos para gerenciar crises do que uma instituição ad hoc. Em outros termos, a existência de uma organização como o FMI evitaria que países desenvolvidos mas não hegemônicos, como Japão, Alemanha e Reino Unido, lograssem "pegar carona” nos esforços do hegemon e não 
contribuíssem para a estabilidade do regime financeiro internacional quando este se encontrasse sob risco.

Este trabalho propõe uma explicação alternativa: o governo dos Estados Unidos delega o gerenciamento de crises financeiras ao FMI porque isto reduz ao máximo a influência do Congresso no processo, e assim aumenta a autonomia do Departamento do Tesouro. O sistema político norte-americano confere ao Congresso grande poder para interferir nas decisões do governo federal. Um dos poderes mais importantes do Congresso é o poder de alocar recursos no orçamento. Se a gestão das crises financeiras internacionais não fosse delegada a uma organização internacional, o Congresso teria grande capacidade de influenciar as decisões a respeito de quem receberia ajuda, em que montante, e sob que condições. Ao delegar a gestão de tais episódios a uma organização internacional, o governo norteamericano os retira da esfera da deliberação política e reduz a influência do Congresso. Neste sentido, o FMI serve como um mecanismo de evasão ${ }^{2}$, por meio do qual atores domésticos são impedidos de influenciar determinadas decisões.

\subsection{PLANO DO TRABALHO}

Este trabalho analisa a estratégia de gestão da crise da dívida executada pelo governo norte-americano e pelo FMI entre 1982 e 1992, levando em conta a influência da política doméstica dos EUA.

O capítulo 2 apresenta a abordagem teórica que será utilizada. Tendo por base a abordagem de principal-agente, o capítulo desenvolve um modelo que propõe que organizações internacionais são úteis para aumentar a influência do Poder Executivo vis-à-vis o Legislativo em questões que possam ser enquadradas como temas de política externa.

O capítulo 3 introduz os atores institucionais do caso em estudo: o Executivo e o Legislativo norte-americanos, o Federal Reserve Board e o Fundo Monetário Internacional. O objetivo deste capítulo é apresentar o ambiente institucional e os limites à ação de cada ator.

No capítulo 4, começa o estudo de caso. Este capítulo analisa o período que vai de agosto de 1982 a fevereiro de 1983. Nestes seis meses, o governo norte-americano tomou as principais decisões sobre como lidar com o problema da dívida — incluindo a decisão de delegar a gestão da crise para o FMI.

\footnotetext{
${ }^{2} \mathrm{O}$ termo foi cunhado por Martin (2000) para denominar o uso de acordos executivos como forma de evitar acordos que exijam apreciação por parte do Congresso.
} 
O capítulo 5 analisa o processo de aprovação, por parte do Congresso norteamericano, do pedido de aumento de capital do FMI. A análise deste episódio mostra que havia grandes resistências no Congresso à estratégia do governo para a crise, e que a delegação para o FMI foi uma forma de minimizar as possibilidades de interferência do Legislativo sobre a questão.

O capítulo 6 apresenta o Plano Baker, anunciado em outubro de 1985 como um programa ambicioso de superar a crise fomentando o "crescimento sustentável" dos países devedores. Neste capítulo, argumento que o Plano Baker foi, principalmente, uma forma de o governo manter a iniciativa política sobre a crise da dívida, reforçar a delegação para o FMI e obter acesso aos grandes recursos financeiros do Banco Mundial.

O capítulo 7 analisa o Plano Brady. Anunciado em março de 1989 pelo novo secretário do Tesouro, Nicholas Brady, o Plano incluía na estratégia norte-americana a intenção expressa de reduzir a carga da dívida dos países devedores. Procurarei mostrar, nesse capítulo, que o Plano Brady foi uma resposta do Executivo ao crescente ativismo do Congresso, que passou a exigir mudanças na estratégia para a dívida como forma de restaurar mercados externos para os produtos agrícolas e industriais norte-americanos.

Finalmente, o capítulo 8 sintetiza as conclusões do estudo de caso. 


\section{Abordagem teórica}

Para tentar explicar por que os EUA delegaram ao FMI a gestão da crise da dívida dos anos 80, é necessário entender as razões que levam os Estados nacionais a delegar certas tarefas para organizações internacionais.

A disciplina de Relações Internacionais ainda tem pouco a dizer sobre o fenômeno da delegação internacional. Isto se deve, em grande medida, à hegemonia do realismo até meados dos anos 70 e ao fato de que seu principal desafiante a partir de então foi a abordagem institucionalista neoliberal.

O realismo tradicionalmente vê a política internacional como um conflito permanente por poder entre Estados nacionais em luta pela sobrevivência. Neste mundo, não há muito espaço para organizações internacionais. Para os realistas, regras e organizações internacionais são instrumentos da política dos Estados mais fortes e não possuem independência nem impacto autônomo. Resulta desta visão que, para entender os fenômenos e as transformações do sistema internacional, é mais relevante estudar a distribuição de poder entre os atores estatais do que as organizações criadas por eles. O institucionalismo neoliberal, por seu turno, embora se proponha a trazer novamente as instituições internacionais para o foco dos estudos, trata-as "num nível tão geral que ele tem pouco a dizer sobre os arranjos institucionais particulares que organizam a política internacional" (Abbott e Snidal, 1998, p. 6). Exemplo desta forma de estudar as instituições internacionais aparece na sugestão de Keohane de que os trabalhos em relações internacionais abandonassem "conceitos tradicionais de organizações internacionais como entidades altamente institucionalizadas com estruturas formais explicitamente desenvolvidas" (1975, p. 361). O conceito de "regimes" representou provavelmente o maior golpe ao estudo de organizações internacionais, pois oferecia uma explicação à manutenção da ordem internacional com base em um conceito amplo de instituições internacionais, das quais as organizações formais seriam apenas um caso particular ${ }^{3}$.

Por isso, para entendermos o fenômeno da delegação internacional é necessário voltarmo-nos para os trabalhos que estudam o Congresso norte-americano. É nessa área da 
Ciência Política que encontraremos um grande corpo teórico sobre o relacionamento entre as burocracias e os políticos eleitos, entendidos como atores em uma relação diádica e conflituosa.

Nessa perspectiva, a questão central é se o poder político é capaz de controlar uma burocracia - o que leva inevitavelmente ao problema referente aos meios que os políticos dispõem para controlar os burocratas ${ }^{4}$. Para responder a esta questão, a Ciência Política encontrou, na Economia, uma abordagem que lhe permitia criar modelos formais da burocracia: a abordagem do principal-agente. Criada inicialmente para procurar formas de reduzir o risco moral em contratos de seguro, esta abordagem foi depois adaptada para qualquer relacionamento no qual um ator delega uma tarefa para outro ${ }^{5}$ e tornou-se a base para muitas pesquisas sobre burocracias domésticas, que iriam influenciar a disciplina de Relações Internacionais.

Este trabalho se baseia nesta abordagem. A pergunta que ele propõe é em que medida a delegação da gestão da crise da dívida dos anos 80 para o FMI foi causada por fatores da política doméstica norte-americana. Para respondê-la, vamos inicialmente revisar a bibliografia existente sobre delegação para organizações internacionais. Depois, vamos enumerar, da literatura sobre a crise da dívida, as principais explicações para a delegação para o FMI. Por fim, será apresentada uma explicação alternativa às existentes e que será testada na pesquisa empírica.

\subsection{POR QUE DELEGAR?}

No plano internacional, a delegação não é estritamente necessária para a cooperação. A experiência em diversas áreas tem mostrado que os Estados podem cooperar por meio de mecanismos ad hoc, sem necessitar de organizações permanentes. Exemplos disso são o

\footnotetext{
${ }^{3}$ Para duas análises críticas do conceito de regimes, cf. Strange (1982) e Kratochwil e Ruggie (1986). Para uma visão geral do estudo de relações internacionais até os anos 80, cf. Rochester (1986).

${ }^{4}$ A obra clássica de Niskanen, Bureaucracy and representative government (1971), inaugura esta abordagem. Niskanen propunha que as burocracias, em função de deterem o monopólio sobre o suprimento de um serviço público e possuírem mais informações do que o Legislativo, eram capazes de maximizar seus orçamentos. Por isto, as burocracias seriam exageradamente grandes, gastariam demais e atuariam mais do que a sociedade gostaria, contribuindo para o inchaço do Estado (Shepsle e Bonchek, 1997, pp. 352-353). Num refinamento desta idéia, Romer e Rosenthal (1978) propunham que as burocracias, por deterem poder de agenda, conseguiam apresentar uma escolha do tipo "pegar ou largar" ao Legislativo, e assim maximizavam seu orçamento. Esta visão começaria a ser questionada pelo trabalho famoso de Miller e Moe (1983), que colocava em dúvida a assimetria de poder e informação entre os dois atores e que estabeleceu o debate central da subdisciplina. ${ }^{5}$ Spence \& Zeckhouser (1971) é o trabalho que inaugura esta abordagem na área de seguros. Ross (1973) apresenta um modelo de uso geral.
} 
Clube de Paris (que congrega os principais países credores), o G-8 (fórum dos chefes de Estado dos principais países industrializados e da Rússia) e o G-20 Financeiro (fórum de articulação para reforma do sistema financeiro composto pelos 20 países com maior peso econômico). Ademais, a delegação sempre embute o risco de que as organizações saiam do controle dos Estados. A despeito disto, um número crescente de questões de política internacional tem sido delegadas a organizações internacionais. Por que os Estados delegam autoridade a tais organizações?

A literatura sobre esta questão ainda é incipiente. O modelo básico de raciocínio, derivada da teoria de principal-agente ${ }^{6}$, é a de um "principal" (o Legislativo, o Executivo ou um Estado nacional) que delega autoridade sobre uma questão para um "agente" especializado (uma burocracia). Como o "principal” é um ator racional, ele somente delegará autoridade quando os benefícios de fazê-lo forem maiores do que os custos. Os benefícios relacionam-se ao aumento da eficácia e da eficiência na realização de uma tarefa oferecida pela divisão de trabalho entre principal e agente. Os custos, por seu turno, correspondem à diferença entre as preferências do principal e a forma como o agente efetivamente atua ("perdas de agência" ou shirking), adicionados aos custos incorridos pelos principais incorrem para supervisionar o agente (“custos de agência"). As perdas de agência advêm da autonomia que o agente possui, por ser uma entidade separada do principal: ele tem seus próprios interesses, possui informações às quais o principal não tem acesso, e seu comportamento só pode ser observado pelo principal de forma imperfeita. Esta autonomia, ao mesmo tempo em que permite que uma questão seja tratada de forma mais eficiente ou eficaz, abre a possibilidade de que ela seja tratada diferentemente da forma como o principal preferiria.

\subsubsection{O PROBLEMA DO CONTROLE DO AGENTE}

O principal pode tomar medidas para reduzir as perdas de agência. Todos os instrumentos, porém, são custosos, e por isso quem delega enfrenta o trade-off entre grau de controle do agente e custo do seu controle. É impossível eliminar as perdas de agência totalmente, e a partir de certo ponto é contraproducente aumentar a supervisão, pois o aumento dos custos de agência torna-se maior do que a redução das perdas de agência.

Boa parte da literatura sobre delegação dedica-se a propor e analisar instrumentos de controle do agente, e que portanto reduzam as perdas de agência. Os instrumentos podem

\footnotetext{
${ }^{6}$ Cf. Kiewiet e McCubbins (1991), Bendor, Glazer e Hammond (2001) e Miller (2005).
} 
divididos em quatro categorias, duas das quais são ex post (desenho de contrato e monitoramento) e duas são ex ante (mecanismos de seleção do agente e procedimentos operacionais).

Desenho de contrato: trata-se de estabelecer, no contrato de delegação, um conjunto de incentivos e sanções que remunerem o agente por comportar-se de acordo com as preferências do principal e o punam por agir contrariamente a elas. Como a literatura sobre remuneração em organizações tem mostrado, montar estruturas de incentivo adequadas é uma tarefa muito difícil, pois elas tendem a produzir resultados diferentes daqueles pretendidos pelo principal (Kiewet e McCubbins, 1991, pp. 27-29).

Monitoramento: como um dos problemas da delegação é o monopólio que o agente exerce sobre determinadas informações, o principal pode minizar este monopólio montando mecanismos para obter estas informações. No nível mais básico, ele pode requisitá-las diretamente do agente. O problema desta medida é que o agente tem incentivos para falsificar e omitir informações, de maneira a convencer o principal de que está fazendo um trabalho perfeito. Por isso, formas de monitoramento externo são mais eficazes (Kiewet e McCubbins, 1991, pp. 31-33).

O monitoramento externo pode ser dividido em duas categorias: "patrulhas policiais" e "alarmes de incêndio". No primeiro caso, o principal cria mecanismos diretos de monitoramento externo, como auditorias e investigações. No segundo caso, o principal cria mecanismos que permitam que terceiros diretamente afetados pela atuação do agente reportem ao principal casos de violação do contrato de delegação, contando assim com os "alarmes de incêndio" desses atores para saber quando um agente está deixando de trabalhar adequadamente. O mecanismo de "patrulhas policiais" é centralizado e tende a ser mais custoso do que o de "alarmes de incêndio", que é descentralizado (McCubbins e Schwartz, 1984).

Procedimentos operacionais: são mecanismos que de alguma forma direcionam o processo de tomada de decisão das burocracias, favorecendo determinados resultados (McCubbins, Noll e Weingast, 1987, Balla, 1998, p. 663). O principal pode, por exemplo, conferir poder de veto sobre as decisões do agente a um terceiro, de maneira a evitar que o agente cause dano ao principal. Pode, também, obrigar o agente a consultar determinados atores externos em seu processo decisório; desta forma, ele 
confere influência sobre a burocracia a certas partes interessadas. Pode, por fim, criar uma estrutura de remuneração e promoção dos funcionários da burocracia que favoreça aqueles que cumpram determinadas metas, estabelecidas pelo principal ${ }^{7}$.

Este tipo de mecanismo reduz a flexibilidade e a agilidade do agente, além de provocar um incentivo à manutenção do status quo. Portanto, estas formas de controle serão tanto mais úteis quanto maior for a utilidade do status quo para o principal, e quanto maior o dano que o agente pode causar ao principal se agir contrariamente às suas preferências (Kiewet e McCubbins, 1991, p. 34).

Mecanismos de seleção do agente: trata-se de formas de recrutamento e seleção de pessoal que favoreçam a escolha de indivíduos com preferências similares às do principal (Calvert, McCubbins e Weingast, 1989, Kiewet e McCubbins, 1991, pp. 2931). O principal pode, por exemplo, exigir qualificações para preencher os cargos decisórios de uma burocracia (educação formal, tempo de experência na iniciativa privada, etc.) que façam com que a burocracia seja sempre comandada por indivíduos que, em sua maioria, tenham preferências similares às suas.

Quando associados a procedimentos administrativos que criem certo grau de insulamento, estes mecanismos de seleção podem servir para garantir que a burocracia atue de acordo com as preferências do principal mesmo depois que este deixe o poder, garantindo a continuidade das políticas públicas desejadas por ele. De fato, dada a incerteza política inerente a qualquer democracia, uma coalizão que chegue ao poder teria fortes incentivos para criar burocracias com preferências fixas e assim "travar" a execução de uma determinada política pública. Neste caso, o principal abriria mão de parte do seu controle sobre o agente em troca de maior continuidade de uma política.

Uma burocracia também pode ser estruturada de maneira a que os seus cargoschave sejam trocados quando muda o principal. É que propõe Moe (1987), ao argumentar que o grau de controle da burocracia pelo presidente é subestimado pela literatura norte-americana, pois ele teria o poder de indicar os ocupantes dos cargos de liderança e policy-making nas agências federais. Neste caso, o principal daria mais prioridade à flexibilidade do agente (ou seja, à possibilidade de poder alterar suas

\footnotetext{
${ }^{7}$ Um exemplo deste mecanismo é a legislação que rege o Serviço Exterior Brasileiro, especialmente a Medida Provisória 319, que estabeleceu diversos incentivos para que os diplomatas aceitem transferências para postos considerados mais difíceis. Outro exemplo são as regras do Departamento de Estado que obrigam seus funcionários a serem transferidos para "postos de sacrifício" (hardship posts), como Bagdá ou Cabul.
} 
preferências por meio da troca dos seus principais executivos) do que à continuidade administrativa ${ }^{8}$.

A maior parte literatura sobre delegação concorda que os mecanismos de controle $e x$ ante são mais efetivos do que os ex post. Ademais, ela salienta que, no que tange ao estabelecimento de mecanismos ex ante, o principal enfrenta o trade-off entre maior controle de curto prazo sobre o agente e maior continuidade das políticas públicas delegadas a ele. Ou, como afirmam Shepsle e Bonchek (1997), “a proteção com relação ao coalition drift é obtido ao preço de um maior potencial de bureaucratic drift", (p. 375).

A existência de tal trade-off é um sinal de que é impossível determinar que mecanismos de controle serão escolhidos pelo principal se não se conhece as particularidades da política em questão, do ator que delega e da burocracia a quem a política é delegada. Afinal, a abordagem de principal-agente é um modelo, e como tal precisa de informações adicionais, obtidas empiricamente, para oferecer resultados palpáveis a uma situação particular que se pretenda analisar.

\subsubsection{PARTICULARIDADES DA DELEGAÇÃO PARA ORGANIZAÇÕES INTERNACIONAIS}

No caso específico da delegação internacional, algumas características particulares devem ser adicionadas ao modelo básico. A mais importante é a existência de um principal coletivo, pois quem delega é um conjunto de Estados (Nielson e Tierney, 2003, Lyne, Nielson, Tierney, 2006). É importante não confundir um modelo de principal coletivo com um modelo de múltiplos principais. Quando um agente tem mais de um contrato de trabalho, ele tem múltiplos principais. Quando, por outro lado, um agente tem um único contrato de trabalho com um principal que é composto por mais de um ator, ele tem uma relação de delegação com um principal coletivo (Nielson e Tierney, 2003, p. 247) ${ }^{10}$. Nesta situação, um grupo de atores chega a um acordo e negocia um contrato com um agente para realizar uma tarefa. Daí derivam dois problemas. O primeiro é que, quando o principal é um ente coletivo,

\footnotetext{
${ }^{8}$ Deve-se fazer a ressalva de que a maioria dos autores tem salientado o oposto disto, ou seja, como os procedimentos de seleção são usados pelos principais para garantir a criação de political stickiness, ou seja, a continuidade de suas políticas preferidas mesmo depois que eles saírem do poder.

${ }^{9} \mathrm{O}$ coalition drift é a diferença entre as preferências da coligação que ocupa o poder no presente e as preferências das coligações que poderão vir a ocupar o poder no futuro. O bureaucratic drift é a diferença entre as preferências da coligação que ocupa o poder no presente e o comportamento do agente.

${ }^{10}$ A distinção tem conseqüências analíticas importantes, e deve-se estar atento a ela porque a literatura sobre delegação internacional tem dado muito mais atenção ao modelo de múltiplos principais do que ao modelo de principal coletivo, embora, curiosamente, este se mostre empiricamente mais freqüente do que aquele.
} 
a eficiência dos mecanismos de controle do agente é reduzida, pois os atores que compõem o principal enfrentam um problema de ação coletiva: a supervisão do agente é, entre os principais, um bem público, que tenderá a ser fornecido num nível sub-ótimo (Olson, 1999). Por isso, quanto maior o número de principais, maiores tenderão a ser as perdas por agência. O segundo é que, se algum ator ou conjunto de atores que compõem o principal tiver direito a veto, então qualquer decisão que vise a substituir o agente ou renegociar seu contrato terá de ser aprovada por estes atores, e portanto terá de ser preferível, para estes atores, ao status quo. Isto tende a enrijecer a relação entre o principal e o agente, e aumentar a autonomia deste último. Analogamente, quanto maior a heterogeneidade das preferências dos atores que compõem o principal, maior será a autonomia do agente, pois mais difícil será para eles chegar a um acordo que altere o status quo. Como afirmam Nielson e Tierney, "um agente no status quo pode ser insulado da ingerência dos principais, especialmente se a coordenação dentro do principal coletivo for custosa ou se algum membro ou grupo de membros com poder de vetar uma mudança estiver inclinado a fazê-lo" (2003, p. 248).

Entretanto, como apontam Lyne, Nielson e Tierney (2006), mesmo na delegação para OIs há situações nas quais a relação pode ser modelada como a de um principal único ou de múltiplos principais. A primeira situação ocorre quando um Estado contrata uma organização internacional para uma tarefa específica, ou quando um único Estado possui tal quantidade de recursos que ele pode mobilizar, isoladamente, os recursos necessários para tratar de uma questão que é delegada ao agente (ou seja, ele é o hegemon no que tange a esta questão). Neste caso extremo, embora o principal seja coletivo, o Estado com mais recursos tem muito mais poder, junto ao agente, do que os outros, e portanto a relação de delegação reaproximase do modelo de um único principal. Por exemplo, Klepak (2003) propõe que os EUA dominam quase completamente a OEA, por serem o hegemon da região. A segunda situação ocorre quando há delegação de um Estado para um agente, mas este Estado tem mais de um ator doméstico a quem o agente se reporta. Por exemplo, Lyne, Nielson e Tierney (2006) estudam a relação entre os EUA e o Banco Interamericano de Desenvolvimento como uma delegação de múltiplos principais, pois tanto o presidente quanto o Congresso teriam influência direta sobre o agente. 


\subsubsection{ORGANIZAÇÕES INTERNACIONAIS COMO AGENTES}

Os estudos existentes sobre as causas da delegação apresentam três características das organizações internacionais que aumentam sua eficiência e eficácia no tratamento de questões: centralização, especialização e independência.

Centralização refere-se à existência de uma estrutura organizacional. Internamente à organização, esta estrutura estabelece cadeias de comando e obediência e fluxos de informação. Externamente, estabelece regras de participação dos Estados-membros na governança da entidade (Abbott e Snidal, 1998, pp. 9-10). Por exemplo, a estrutura organizacional da ONU confere ao Secretário-Geral o poder de supervisionar todas as atividades da Organização; ao mesmo tempo, estabelece as regras pelas quais os Estadosmembros o elegem.

A especialização é o acúmulo de conhecimento e recursos para tratar de uma determinada questão. No plano internacional, os Estados muitas vezes não possuem recursos, conhecimento técnico, pessoal, credibilidade ou legitimidade suficientes para implementar certas políticas, mas uma entidade externa a eles pode agrupar os recursos necessários e tornar tais políticas possíveis (Hawkins et al, 2006, pp. 13-15).

Independência é a autoridade de atuar com algum grau de autonomia e neutralidade em determinadas esferas (Abbott e Snidal, 1998, p. 9). Esta independência vai além da simples autonomia administrativa que qualquer organização possui como resultado da centralização, e é derivada do fato de que uma organização internacional, embora seja criação dos Estados, não se confunde com nenhum deles. Algum grau de independência é necessário para que uma organização consiga aprimorar a cooperação entre Estados: se uma organização for vista como totalmente subserviente a um dos Estados-membros, os outros se recusarão a admitir sua autoridade.

\subsubsection{BENEFÍCIOS DA DELEGAÇÃo}

A partir destas características, é possível determinar os benefícios que a delegação a organizações internacionais oferece aos Estados. A literatura tem adotado duas perspectivas distintas para deduzir estes benefícios. A primeira perspectiva, que pode ser denominada “estadocêntrica", pressupõe o Estado como unidade de análise; os benefícios da delegação são calculados com base em um Estado tido como unitário e racional. Esta perspectiva é compatível com as tradições teóricas do realismo e do institucionalismo neoliberal, e pode 
mesmo ser considerada uma extensão de seus programas de pesquisa (Keohane e Martin, 1999). A segunda perspectiva, que podemos denominar de "perspectiva de política doméstica”, parte do princípio que as unidades de análise são os atores políticos domésticos (Poder Executivo, Poder Legislativo, burocracias nacionais, grupos de interesse). Esta perspectiva procura identificar quais benefícios a delegação para organizações internacionais oferece para determinados atores domésticos, e não mais para Estados como um todo.

\subsubsection{PerspeCtiva ESTAdOCÊNTRICA}

Esta perspectiva adota o Estado como unidade de análise, considerada como um ator unitário e racional. Nesta perspectiva, estamos interessados em entender por que, dado que estes atores resolvem cooperar em alguma matéria, eles decidem delegar autoridade para uma organização internacional conduzir esta cooperação. Ou seja, procuramos identificar de que maneiras a delegação torna a cooperação internacional mais eficiente ou eficaz.

A literatura apresenta diversos benefícios da delegação, que podem ser esquematicamente divididos em dois grupos: a apoio a interações entre os Estados, e o gerenciamento de operações.

\section{Apoio a interações entre Estados}

No nível mais básico, uma organização internacional oferece um fórum permanente de interação entre Estados sobre determinado tema. Mesmo uma entidade pequena terá um impacto positivo ao manter uma secretaria incumbida de organizar reuniões e manter arquivos. Uma entidade maior terá representantes permanentes de seus Estados-membros e reuniões mais freqüentes, facilitando a interação entre estes Estados nos temas de que trata. Por exemplo, todos os Estados-membros do Conselho de Segurança das Nações Unidas devem manter uma representação permanente junto ao órgão, que se reúne quase diariamente; com isso, qualquer acontecimento que possa ter impacto sobre a segurança internacional será rapidamente discutido pelos representantes dos Estados com assento no CSNU.

A ONU é um caso particularmente interessante de espaço de interação interestatal. Todo ano, a abertura da Assembléia Geral das Nações Unidas apresenta uma oportunidade sem paralelo para contatos entre chefes de Estado e chanceleres. Ademais, os acordos de territorialidade que a ONU possui com os Estados que abrigam suas instalações - em particular com os Estados Unidos, que abrigam sua sede — permitem que determinados 
líderes políticos considerados "hostis" por estes Estados participem de reuniões e interajam com outros líderes ${ }^{11}$. A imunidade de jurisdição se aplica também às missões dos membros das Nações Unidas, mesmo daqueles que não mantêm relações diplomáticas com os países que abrigam suas sedes ${ }^{12}$. A Assembléia Geral também é uma arena permanente de debates sobre política internacional. Freqüentemente, chefes de Estado usam a AGNU como fórum para chamar a atenção dos outros Estados para temas de seu interesse.

Uma organização internacional é útil para resolver problemas de coordenação, ou seja, problemas nos quais, para cada ator, a obtenção de um acordo é mais importante do que o conteúdo do acordo (Ruggie, 1993, p. 16). Estes problemas são geralmente representados pelo jogo da "batalha dos sexos". Alguns padrões técnicos (tais como os de formato de plugs de eletricidade, bitolas de ferrovias, códigos telefônicos para ligações internacionais) são exemplos típicos de tais problemas. Nestes casos, há grandes benefícios em permitir que uma organização internacional tenha poder de agenda e autonomia para definir soluções de coordenação, já que o pior resultado possível é a ausência de um acordo. Entidades como a ISO, a União Postal Internacional e a União Internacional de Telecomunicações são exemplos de organizações que cumprem este papel.

Organizações internacionais são úteis também como locais de produção e acumulação de informação sobre um tema. Elas acompanham as negociações e os acordos entre os Estados-membros em questões particulares, produzindo documentos que permitem que todos eles se mantenham atualizados quanto ao andamento das conversas, mesmo que não possuam representações numerosas ou que os indivíduos que compõem estas representações sejam substituídos.

\footnotetext{
${ }^{11}$ Fidel Castro participou da Assembléia Geral em Nova York em 1979 e 1995, enfrentando a hostilidade de políticos norte-americanos e insistentes pedidos de grupos anticastristas de que seu visto fosse negado (Alvarez, 1995). Somente em uma oportunidade os EUA negaram-se a conceder visto para uma autoridade estrangeira participar de reunião na ONU: em 1988, o Departamento de Estado denegou o visto a Iasser Arafat, que participaria de reunião da AGNU que discutiria a questão da Palestina, por considerá-lo uma "ameaça à nossa segurança" (Reisman, 1989, p. 520). Esta decisão causou uma avalanche de críticas, inclusive dos aliados norteamericanos na OTAN (Lohr, 1988), e levou a AGNU a transferir sua reunião sobre a Palestina para Genebra, onde a ONU também tem sede, para que Arafat pudesse participar (Friedman, 1989, Lewis, 1988d).

12 Desde 1975, a OLP manteve missão de observação junto à ONU, a despeito de ser considerada uma “organização terrorista” pelos EUA. Em 1987, a Lei Anti-Terrorismo aprovada pelo Congresso obrigava o governo a fechar o escritório da OLP. Este dispositivo foi veementemente condenado pela Assembléia Geral, e quando o Departamento de Justiça levou o caso à justiça federal pedindo o fechamento da missão da OLP, o Secretário-Geral da ONU levou à questão à Corte Internacional de Justiça por violação do acordo de sede de 1947 entre os EUA e a ONU (Lewis, 1988a). A CIJ decidiu que a Lei de 1987 estabelecia uma controvérsia com a ONU que deveria, de acordo com os termos do acordo de 1947, ser resolvida por arbitramento (Lewis, 1988b). Pouco depois, a corte federal decidiu que o acordo de 1947 impedia o governo de pedir o fechamento da missão da OLP, a despeito da Lei de 1987 (Lubasch, 1988).
} 
Ademais, as organizações internacionais produzem e compilam pesquisas relevantes sobre os temas de que tratam, e assim colaboram para avançar o conhecimento sobre eles. Em virtude do conhecimento que possuem, funcionários das OIs assumem papéis importantes em comunidades de especialistas que desenvolvem e difundem idéias e conceitos de governança internacional (Haas, 1992). Por exemplo, a CEPAL e seu corpo técnico tiveram papel fundamental nos estudos sobre desenvolvimento econômico; o secretariado do PNUMA compila e publica informações e pesquisas sobre a redução na camada de ozônio; e o da OCDE coleta, produz e publica uma grande quantidade de informações relevantes para a coordenação macroeconômica em nível internacional (Abbott e Snidal, 1998, p. 12).

Finalmente, em virtude de sua autonomia e especialização, organizações internacionais geralmente detêm algum poder de agenda sobre os temas de que tratam. Graças a este fato, elas podem servir para resolver problemas de cooperação em situações de equilíbrios múltiplos, induzindo um equilíbrio quando as preferências dos atores são cíclicas $^{13}$. Ademais, este poder de agenda, mesmo que limitado, lhes permite manter em pauta problemas que, em virtude de um momento político desfavorável, seriam relegados para um segundo plano. Por exemplo, o PNUMA manteve o tema da destruição da camada de ozônio em pauta quando as negociações entre Estados atingiram um impasse, e posteriormente articulou o apoio ao Protocolo de Montreal de 1987 (Abbott e Snidal, 1998, p. 17). Como prevê a literatura sobre a questão, este poder de agenda pode ser utilizado pelo agente para avançar suas políticas preferidas; a capacidade das OIs de induzir a cooperação, portanto, tem um preço, que é o viés a favor de determinadas políticas. Como veremos logo adiante, este viés pode ser útil em determinadas situações, e portanto pode ser, para alguns Estados, uma vantagem da delegação.

\section{Gerenciamento de operações}

No plano do gerenciamento de operações, os benefícios oferecidos pelas organizações internacionais são ainda maiores do que no plano de apoio à interação interestatal.

O primeiro, e mais evidente, benefício neste plano é o da união de recursos de diversos Estados para a consecução de um objetivo comum. A centralização que caracteriza

\footnotetext{
${ }^{13}$ Cf. o trabalho seminal de McKelvey (1976) sobre instabilidade de políticas e poder de agenda, e os trabalhos de Shepsle sobre o Congresso norte-americano, nos quais argumenta que o sistema de comitês pode produzir "equilíbrios induzidos pela estrutura" ao determinar quais alternativas são elegíveis e estruturando os poderes de voto e veto dos vários atores no processo de seleção (Shepsle, 1979, Shepsle e Weingast, 1984, 1987). Para uma revisão da bibliografia sobre a questão, ver Cox e Shepsle (2007).
} 
as OIs lhes permite administrar estes recursos de forma mais eficiente do que se os Estados os administrassem diretamente por meio de mecanismos ad hoc de cooperação. Ademais, a união de recursos permite que as OIs operem em escala maior do que seria possível para qualquer Estado operando isoladamente, o que aumenta sua eficiência. Por exemplo, a OTAN maximiza a capacidade de defesa de seus Estados-membros ao agrupar, sob um comando único, recursos militares oriundos de todos eles. O Banco Mundial, ao agrupar fundos de diversos Estados, é capaz de empreender projetos mais ambiciosos do que cada Estado poderia empreender individualmente, ao mesmo tempo dividindo o risco entre eles e, portanto, minimizando o risco assumido por cada Estado (Abbott e Snidal, 1998, pp. 13-14).

Outro benefício trazido pelas OIs é permitir aos Estados-membros formar equipes multinacionais para tratar de determinados temas. Por exemplo, a Organização Mundial de Saúde possui diversas forças-tarefa que agrupam os esforços e recursos de instituições de inúmeros países ${ }^{14}$. A OTAN permite que os membros das forças armadas de seus Estadosmembros trabalhem conjuntamente no desenvolvimento de planos militares, realização de exercícios, especificação de equipamentos e condução de batalhas (Abbott e Snidal, 1998, p. $15)$.

Organizações internacionais também têm vantagens no que tange à produção de informações relativas ao cumprimento dos acordos de que tratam, pois têm mais legitimidade para fazer verificações junto aos seus Estados-membros. Por exemplo, organizações como a OPAQ (Organização para a Proibição das Armas Químicas) e a AIEA (Agência Internacional de Energia Atômica) podem realizar inspeções em instalações pertencentes aos seus Estadosmembros que não seriam aceitáveis se fossem empreendidas diretamente por outros Estados. A qualidade da informação sobre cumprimento é essencial para viabilizar a cooperação no nível internacional, pois a falta de informações confiáveis gera incentivos muito fortes para que cada Estado tente "pegar carona" nos esforços dos outros (Keohane, 1984).

Organizações internacionais também são úteis para interpretar e complementar normas e acordos já fechados. Como em qualquer contrato, é muito difícil para as partes em um tratado internacional prever todas as contingências passíveis de acontecer. Este problema da imperfeição dos contratos é fonte de risco para os signatários de um acordo. No plano

\footnotetext{
${ }^{14}$ Alguns exemplos de forças-tarefa organizadas pela OMS são a Aliança Global contra Doenças Respiratória Crônicas (GARD), a Rede Global de Alerta e Resposta a Epidemias e a Força-Tarefa Global sobre Controle do Cólera. Mais informações sobre cada força-tarefa podem ser obtidas, respectivamente, em <www.who.int/gard/en/>, <www.who.int/csr/outbreaknetwork/en/> e <www.who.int/cholera/en/>.
} 
nacional, o sistema legal reduz este problema ao fornecer regras e princípios gerais, além de uma instância de apelação que pode interpretar o contrato à luz das contingências. As organizações internacionais podem cumprir, mesmo que parcial e imperfeitamente, este papel, ao receberem delegação de autoridade legal e desta forma servirem como mecanismos de solução de controvérsias e como produtores de novas normas a partir das já existentes.

A neutralidade é essencial para uma instância judicial, tanto no plano nacional quanto no internacional. Por um lado, a instância deve julgar qualquer controvérsia através de um "véu de ignorância" a respeito de quem são os litigantes; por outro, dada a imperfeição inerente às normas e aos contratos, deve ser capaz de interpretá-los por conta própria (Hawkins et al, 2006, pp. 17-18). Nenhuma entidade nacional é neutra o suficiente para conseguir cumprir o papel de árbitro internacional; somente uma organização formalmente independente dos Estados pode alegar sê-lo. Por isso, quando criam uma organização internacional encarregada de resolver controvérsias em uma determinada área, os Estados procurarão torná-la o mais autônoma possível, para aumentar sua legitimidade e sua credibilidade $^{15}$. Embora a execução das decisões de tais entidades dependa da cooperação dos Estados envolvidos, o simples fato de que estas decisões tenham sido resultado de um processo legal conduzido por uma instância neutra aumenta a probabilidade de que sejam obedecidas. Para além da legitimidade, algumas OIs detêm recursos suficientes para serem capazes de punir o não-cumprimento de suas decisões por meio de seu poder de negar benefícios, como as instituições financeiras internacionais (Abbott et al, 2000, p. 418).

Ademais, as contingências freqüentemente exigem que os acordos sejam reinterpretados ou renegociados — ou seja, que sejam produzidas novas normas. A gestão de um acordo por meio de uma organização internacional permite que a produção de novas normas seja assumida diretamente pela organização, com base em procedimentos previamente definidos, em vez de pelos Estados partes, que teriam de empreender longas e custosas negociações diretas (Abbott e Snidal, 1998, pp. 15-16, Abbott et al, 2000, p. 417). Um exemplo excelente deste benefício é o papel que as organizações da União Européia têm no estabelecimento de normas comunitárias.

Delegar uma questão a uma OI também pode servir para aumentar a credibilidade do compromisso dos Estados-membros com relação a uma determinada solução. Isto é particularmente importante quando ocorre inconsistência temporal de preferêncas, ou seja, 
quando um determinado curso de ação é preferível no longo prazo, mas os Estados têm fortes incentivos para agir diferentemente no curto prazo. O exemplo mais típico de tal inconsistência ocorre no plano da política fiscal: no longo prazo, a manutenção de orçamentos públicos equilibrados oferece grandes benefícios, mas a curto prazo os governos têm fortes incentivos para aumentar seus gastos (Hawkins et al, 2006, p. 18-19).

Para aumentar a credibilidade de compromissos em situações de inconsistência temporal de preferências, os Estados podem delegar o gerenciamento do compromisso para uma burocracia com preferências claras e grande grau de independência. Esta independência permitirá que esta burocracia busque os objetivos de longo prazo e ignore os incentivos de curto prazo para afastar-se deles. Esta é a lógica por trás da adoção de bancos centrais independentes ${ }^{16}$, e, no plano internacional, foi a razão que levou os membros da Comunidade Européia a estabelecer o Banco Central Europeu, criado para executar uma política monetária conservadora.

Outro benefício que pode advir da execução de uma política por parte de uma organização internacional é a criação de viés político, ou, como comumente denominado na literatura sobre política norte-americana, de efeitos de lock-in. Os Estados fortes num determinado momento podem delegar um tema a uma OI estruturada de maneira a possuir preferências e valores similares aos seus, ou que sempre lhes garanta peso desproporcional em seu processo decisório. Quando estes Estados se enfraquecerem, o tratamento do tema continuará refletindo suas preferências (Ikenberry, 2003, p. 52), ou eles continuarão a ter peso no processo decisório a despeito de seu declínio relativo; no mínimo, o poder de agenda detido pela organização evitará que políticas alternativas prejudiciais a estes Estados venham a ser adotadas. Em outros termos, a delegação pode congelar a distribuição de poder em relação a um determinado tema. Evidentemente, este efeito requer que a OI possua autonomia suficiente para resistir a pressões por mudanças em suas preferências ou em seu processo decisório quando a distribuição de poder entre Estados se alterar.

Um caso evidente de uma organização que cria efeitos de lock-in é o Conselho de Segurança da ONU, no qual cinco Estados-membros detêm assentos permanentes com poder de veto. Estes cinco Estados obtiveram seus assentos permanentes quando o Conselho foi criado, e portanto a distribuição de poder no órgão reflete a distribuição de poder vigente no

\footnotetext{
${ }^{15}$ Para uma excelente discussão a respeito deste ponto, ver Alter (2006), particularmente seu argumento de que cortes internacionais são um caso particular de agentes internacionais que a autora denomina de "trustee agents". ${ }^{16}$ Para um resumo do argumento, cf. Bernhard, Broz e Clark (2002), pp. 704-707.
} 
sistema internacional no fim da II Guerra Mundial, não a distribuição vigente hoje (Hawkins et al, 2006, pp. 19-20).

Organizações internacionais também são úteis para legitimar determinadas políticas. As organizações internacionais detêm legitimidade para tratar dos temas que lhes são delegados em virtude de sua especialização, domínio do conhecimento técnico e alegada neutralidade. Os Estados podem se valer desta legitimidade para facilitar a adoção de determinadas políticas que, se fossem implementadas diretamente por eles, seriam muito mais questionadas ${ }^{17}$. Ao mesmo tempo, quando determinado tratamento de um tema é apoiado e defendido por uma organização internacional, a inação sobre este tema pode ter sua legitimidade reduzida, o que cria incentivos à ação. Em outros termos, a legitimidade aumenta a eficácia e a eficiência de um processo de cooperação. Por exemplo, as decisões da Corte Européia de Justiça são tidas como equilibradas e bem fundamentadas, o que lhes confere legitimidade e aumenta sua eficácia.

A legitimidade é particularmente importante quando há elevados custos envolvidos numa determinada política. Por exemplo, o governo dos EUA buscou aprovação do Conselho de Segurança da ONU para as duas invasões do Iraque (em 1990, na Guerra do Golfo, e em 2003), porque esta aprovação aumentaria a legitimidade da sua ação militar. Na Guerra do Golfo, a aprovação do CSNU levou outros Estados a apoiarem a invasão, que deixou de ser uma ação unilateral dos EUA para tornar-se uma iniciativa da "comunidade internacional". $\mathrm{Na}$ Guerra do Iraque, a ausência de aprovação do CSNU abriu a possibilidade de que vários Estados discordassem da subseqüente ação unilateral norte-americana, aumentando seu custo político para os EUA.

\subsubsection{PERSPECTIVA DE POLÍTICA DOMÉSTICA}

Esta perspectiva abandona o pressuposto do Estado como ator unitário e racional. Ela abre a "caixa preta" do Estado, procurando identificar seus componentes e as pressões exercidas pelo seu ambiente político doméstico sobre seu comportamento. Assim, as unidades de análise passam a ser os atores políticos internos: os ocupantes dos poderes Executivo, Legislativo e Judiciário e das agências burocráticas. Estes atores estão sujeitos a pressões oriundas da sociedade, da qual precisam, em maior ou menor grau, de apoio para manterem suas posições no jogo político. 
Nesta abordagem, as alternativas não se limitam apenas a delegar ou não. A primeira escolha é entre cooperar no plano internacional para tratar de determinada questão, ou tratá-la unicamente no nível doméstico. Quando a cooperação internacional é escolhida, há a opção entre tratar da questão por meio de mecanismos ad hoc ou por meio da delegação a uma organização internacional.

A proposição fundamental dos autores que trabalham nesta perspectiva é que um determinante-chave da delegação de tarefas a organizações internacionais é o sistema político doméstico dos Estados. Ou seja, grande parte da motivação dos Estados para criar OIs emana da luta política doméstica.

Em virtualmente todos os sistemas políticos contemporâneos, a política externa é formulada e executada pelo Poder Executivo e suas agências. Portanto, a cooperação no nível internacional, com ou sem delegação a uma organização internacional, é levada a cabo pelo Executivo. Como veremos, este fato tem conseqüências teóricas importantes, pois a decisão de cooperar pode implicar em fortalecimento de alguns atores domésticos, em detrimento de outros.

\section{Moravcsik: como a cooperação internacional redistribui poder entre atores domésticos}

Em seus trabalhos sobre a integração européia, Andrew Moravcsik propõe que a política doméstica oferece incentivos para a cooperação internacional porque esta aumenta o poder dos Executivos nacionais. Em primeiro lugar, ele argumenta que negociações e instituições internacionais realocam recursos políticos, pois mudam o contexto doméstico no qual as decisões são tomadas e implementadas. Em segundo lugar, esta realocação de recursos geralmente favorece os atores que participam diretamente das negociações e das instituições internacionais, ou seja, os ocupantes do Poder Executivo (Moravcsik, 1994, p. 1).

Moravcisk parte da abordagem dos “jogos de dois níveis” de Putnam (1988) para chegar a conclusões opostas a ela. Para esta abordagem, Executivos com fortes restrições em seu nível doméstico teriam vantagem em negociações internacionais, pois seu win-set seria mais limitado do que o dos Executivos com restrições domésticas mais fracas. Em virtude disso, a literatura deu grande importância aos incentivos que os governos nacionais têm para "amarrarem as mãos" no plano doméstico como forma de melhorar sua posição negociadora internacional. Ora, esta conclusão assume que as negociações internacionais sejam mais

\footnotetext{
${ }^{17}$ No plano mais amplo, organizações internacionais são parte do processo de institucionalização que visa a
} 
importantes do que as negociações domésticas, ou seja, que os Executivos preferem ter uma posição negociadora forte no plano internacional do que ter uma posição negociadora forte no plano doméstico. Porém, se o contrário for verdadeiro (ou seja, se os governos preferirem, em alguma questão, serem fortes domesticamente a serem fortes internacionalmente), a abordagem de dois níveis pode ser virada de ponta-cabeça e nos levar à conclusão que de uma ótima maneira de impor suas preferências na luta política interna é ter um win-set limitado externamente (Moravcsik, 1994, pp. 1-2). Em outros termos, ao mesmo tempo em que a cooperação internacional pode limitar a autonomia externa do Poder Executivo, ela aumenta sua influência interna e, portanto, ela resolve não apenas problemas internacionais de ação coletiva, mas também problemas domésticos (ibidem, p. 3). Como afirma Moravcsik, "em casos extremos, os Executivos podem saudar restrições multilaterais sobre a soberania nacional [...] desde que elas aumentem sua autonomia em casa - uma predição paradoxal para teorias convencionais de relações internacionais" (ibidem, p. 2).

A realocação de recursos por meio de cooperação internacional pode ser feita de duas formas. A primeira é a transformação de questões tradicionalmente definidas como de política interna em questões de política internacional. A segunda é a delegação de questões de política externa para uma organização internacional. Esta realocação se dá em quatro frentes: (i) altera o poder de agenda em favor do Poder Executivo, (ii) modifica os procedimentos de aprovação de decisões, reduzindo os pontos de veto dos atores domésticos, (iii) cria assimetrias de informação a favor do Executivo e (iv) aumenta a legitimidade das políticas propostas pelo Executivo (ibidem, pp. 8-14).

Embora o argumento apresentado originalmente por Moravcsik proponha que a cooperação internacional (e não apenas a delegação) aumenta o poder dos governos, pode-se verificar que a delegação tende a aprofundar este efeito; em determinadas circunstâncias, é a delegação que o torna possível. Alguns dos mecanismos de realocação de recursos enumerados acima só funcionam se houver uma entidade autônoma e especializada. Outros não dependem da existência de tal entidade, mas atuam de forma mais eficaz quando ela existe. Ademais, a delegação é útil não apenas em temas domésticos, mas também em temas de política externa: uma organização internacional tende a ser menos influenciada por atores domésticos de um Estado, como o legislativo e o judiciário, do que uma agência doméstica responsável por temas de política externa. Por exemplo, o Congresso pode supervisionar de

legitimar o exercício de poder por parte dos atores mais fortes (Ikenberry e Kupchan, 1990). 
perto as atividades do Departamento do Tesouro e o Departamento de Estado, solicitando todo tipo de informação e convocando seus dirigentes para prestar depoimento em audiências, mas não pode fazer o mesmo com a ONU ou com o Banco Mundial.

\section{Poder de agenda}

Quando um tema deixa o nível doméstico e passa a ser um assunto de política internacional, o Poder Executivo ganha o papel protagônico em seu tratamento. A maior parte dos acordos internacionais não é discutida no Legislativo enquanto não for assinado pelos Executivos e submetido à aprovação interna. Isto transfere o poder de agenda sobre o assunto para o Executivo: um acordo internacional só será discutido internamente depois que os Executivos nacionais de dois ou mais Estados tiverem atingido um acordo. Para o Poder Legislativo, a deliberação a respeito do acordo é bastante restrita, pois os acordos não podem ser modificados em sua essência e, portanto, a ele resta apenas uma decisão de "pegar ou largar" $" 18$.

Esta transferência de poder de agenda para o Poder Executivo é particularmente relevante em Estados, tais como os EUA, nos quais o governo não pode apresentar propostas de legislação. Nestes Estados, o poder de agenda com relação à nova legislação pertence ao Legislativo (em particular às comissões, no caso norte-americano); a cooperação internacional, assim, é uma forma de os Executivos assumirem esse poder e aproveitarem as vantagens que ele confere.

Como afirma Moravcsik, o tratamento de uma questão no plano internacional permite que os Executivos nacionais "cartelizem" o controle da agenda sobre ela (1994, p. 8). Este poder de agenda lhes dá um poder de veto implícito: como sempre cabe aos Executivos negociar acordos e apresentá-los para aprovação interna, nenhum acordo que os Executivos não desejem será sequer apresentado internamente. Ademais, como o processo de aprovação é essencialmente "tudo ou nada", o Executivo impõe ao Legislativo uma escolha entre um acordo e o status quo; os governos podem, portanto, usar seu poder de agenda para apresentar, dentro do conjunto de acordos que o Legislativo prefere ao status quo (o win-set), aquele que melhor atende suas preferências. O formato de "tudo ou nada" também permite ao Executivo jogar a carta da reputação internacional: rejeitar um acordo já assinado pode reduzir a

\footnotetext{
${ }^{18}$ A legislação de alguns Estados, como os EUA, permite que o Legislativo "emende" um acordo internacional, adicionando reservas a ele. Mas mesmo este mecanismo é limitado, pois uma reserva considerada inaceitável
} 
reputação do negociador internacional perante os outros Executivos, o que tende, a longo prazo, a prejudicar sua capacidade negociadora. Finalmente, o poder de agenda confere aos Executivos a possibilidade de manipular estrategicamente o timing, o seqüenciamento e a apresentação das políticas; isto pode ser usado, por exemplo, para assinar acordos internacionais em momentos de grande apoio doméstico, garantindo sua aprovação (id., pp. 9$10)$.

Embora os elementos acima se apliquem indiferentemente a processos de cooperação internacional com ou sem delegação a OIs, pode-se argumentar que a utilização destas últimas amplia ainda mais o poder de agenda dos governos. As organizações internacionais mantêm um fórum permanente de debates entre os representantes dos Estados-membros sobre os temas de que tratam; como estes representantes são indicados pelos Executivos nacionais, estes últimos terão prioridade — quando não exclusividade — na discussão destes assuntos. Quando as preferências de uma OI são alinhadas com as preferências de Executivos nacionais de Estados poderosos, o poder de agenda pode também ser transferido para a própria organização internacional (por exemplo, na pessoa de seu secretário-geral), aumentando ainda mais a distância entre quem detém a iniciativa e os legislativos nacionais.

\section{Procedimentos de aprovação}

O tratamento de um assunto por meio da cooperação internacional - e especialmente por meio da delegação a uma organização internacional — é também uma forma de diminuir as oportunidades de grupos internos se oporem às decisões do Poder Executivo.

Um acordo assinado no âmbito de uma organização internacional é auto-aplicável se não implicar em emendas em seu tratado constitutivo. É o caso, por exemplo, das resoluções do Conselho de Segurança da ONU, que são vinculantes aos Estados-membros da Organização por força do Capítulo VII da Carta da ONU, prescindindo, portanto, de aprovação interna.

Mesmo acordos que exijam mudanças no tratado constitutivo de uma organização são mais fáceis de serem aprovados internamente do que acordos interestatais bi- ou multilaterais, pois recusá-los implica em sinalizar um desengajamento da OI em questão, com possível perda de influência sobre ela a longo prazo, o que aumenta o custo da rejeição. Ademais, as organizações internacionais são particularmente úteis para que os governos nacionais 
agrupem diversas medidas em um único "pacote", que deverá ser aprovado ou rejeitado inteiramente pelos legislativos. Por exemplo, o Congresso dos EUA não pode imiscuir-se em projetos individuais de ajuda internacional do Banco Mundial, mas pode fazê-lo nos projetos de ajuda bilateral empreendidos pela USAID, uma agência federal.

\section{Assimetrias de informação}

A delegação para organizações internacionais tende a dificultar o acesso a informações sobre uma atividade para atores externos ao Poder Executivo. Uma OI é pessoa de Direito Internacional, e portanto goza de prerrogativas similares aos Estados nacionais. Disto decorre que um parlamento ou um juiz não pode requisitar informações diretamente de uma organização internacional, da mesma maneira que o princípio da soberania os impede de requisitar informações de um Estado estrangeiro. Quaisquer informações sobre as operações de uma OI devem ser obtidas sempre por intermédio do Poder Executivo nacional, que é a interface entre o Estado e a organização. Este papel de intermediário oferece ao Executivo (e especialmente aos indivíduos ou grupos, dentro do Executivo, que se relacionam diretamente com a OI) a possibilidade de criar e aproveitar-se de assimetrias de informação com relação aos outros atores políticos domésticos. Tais assimetrias podem limitar ou mesmo impedir o monitoramento da execução de uma política por parte do parlamento, e portanto aumentam a autonomia do Executivo.

A assimetria de informação a favor do Executivo também pode lhe permitir manipular as percepções domésticas. Moravcsik (1994, p. 13) distingue três dimensões que podem ser manipuladas para aumentar o apoio interno ou reduzir a oposição potencial. A primeira é a relevância de uma questão: o Executivo pode "despolitizar" uma questão, tratando-a numa esfera pretensamente neutra, como uma organização internacional. A segunda refere-se às conseqüências de uma medida: o Executivo pode liberar informações de forma seletiva, para não despertar a oposição de determinados grupos que serão afetados negativamente por ela. Finalmente, a terceira é a causalidade de uma política: o Executivo pode usar a cooperação internacional para fazer parecer que uma determinada medida é "necessária" em função do contexto internacional vigente. Desta forma, medidas impopulares podem ser justificadas como sendo causadas por restrições externas, como a necessidade de unir-se à zona do euro, ou de participar de um acordo de livre comércio.

prerrogativa, e portanto deve apenas escolher entre aprovar e rejeitar o acordo. 


\section{Aumento da legitimidade de políticas}

O tratamento de um assunto por meio de negociações e instituições internacionais pode prover fontes adicionais de legitimidade às posições do Poder Executivo. O Executivo possui uma posição privilegiada no enquadramento ideológico da política externa; ele tem acesso desproporcional à carta do "interesse nacional" como pretexto para suas posições políticas no plano internacional. Enquanto, no plano interno, a disputa política é naturalmente vista em termos de luta entre grupos domésticos com interesses conflitantes, no plano internacional a disputa é geralmente enquadrada em termos de luta entre Estados. Daí decorre que geralmente se aceita que o "interesse nacional" deva se sobrepor a todos os interesses particulares, pois ele está relacionado à sobrevivência e à autonomia da comunidade política. Quando o Executivo consegue enquadrar uma questão doméstica como um assunto de política internacional, ele permite que suas decisões sejam legitimadas como as que mais coincidem com o interesse nacional, e não como decisões que favorecem alguns grupos domésticos e prejudicam outros.

Finalmente, a cooperação internacional pode legitimar uma determinada "comunidade epistêmica", aumentando o peso político de suas posições e estabelecendo os termos do debate público sobre um tema de uma forma que dificulte ou mesmo impeça o progresso de adversários daquelas posições. Uma comunidade epistêmica pode ser definida como "uma rede de profissionais com expertise e competência reconhecidas em um determinado tema" que compartilham crenças, valores, modelos causais, critérios de validade do conhecimento e um projeto político comum (Haas, 1992, p. 3). Comunidades epistêmicas formam "elites de conhecimento" (ibidem, p. 10) que podem afirmar-se como detentoras exclusivas de técnicas e métodos necessárias para executar determinadas políticas públicas. Como afirma Sebenius, "comunidades epistêmicas podem enquadrar temas para o debate coletivo, propor políticas específicas, e identificar dimensões importantes para negociações e excluir outras” (1992, p. 355). Da mesma forma que uma comunidade epistêmica pode influenciar governos e levá-los a cooperar em uma determinada área, a cooperação internacional em um tema aumenta o prestígio e a influência do grupo de especialistas naquele tema, legitimando suas posições e realimentando a influência destes especialistas sobre as políticas públicas. 


\section{Delegação, incerteza política doméstica e credibilidade dos compromissos}

Outros autores têm salientado a utilidade da delegação para reduzir a incerteza política temporal oriunda da política interna dos Estados. Da mesma forma que a delegação internacional pode criar viés político que favorece alguns Estados em detrimento de outros, também pode criar um viés que favorece determinados atores domésticos. Ou seja, a delegação para organizações internacionais pode ser usada para criar efeitos de lock in domésticos, reduzindo as alternativas políticas disponíveis para governos futuros (Bernhard, 2002, pp. 8, 10-11, Moravcsik, 2000, p. 18).

A chave para se obter este efeito é delegar uma política a uma organização autônoma, mas com viés favorável a determinadas políticas. Os governos futuros serão obrigados a aceitar estas políticas ou pagar o custo de romper com a OI. Quanto maior for este custo, menor será a probabilidade de que ocorra um rompimento no futuro.

Um caso particular deste argumento é a idéia que a delegação a uma OI aumenta a credibilidade dos compromissos assumidos por um governo quando há inconsistência temporal de preferências ou quando há grande oposição interna a eles. A lógica deste argumento tem duas facetas: por um lado, a delegação internacional reduz as oportunidades de veto por parte de atores domésticos, aumentando a estabilidade das políticas delegadas; por outro, ela "amarra as mãos" dos governos nacionais, dificultando mudanças de rumo nestas políticas (Mansfield et al, 2002, Mansfield e Pevehouse, 2006, Pevehouse, 2002, Pollack, 2006, pp. 168-175).

Note-se que este papel de criação de viés político pode ser alcançado também com a delegação a burocracias domésticas. De fato, quando houver agências burocráticas domésticas com autonomia e comprometimento político suficientes, a delegação a uma organização internacional será pouco lucrativa. Nestas situações, os Executivos nacionais tenderão a manter as questões no âmbito doméstico, evitando não apenas a delegação, mas até mesmo a cooperação internacional. A decisão de delegar a uma OI, portanto, envolve um cálculo, da parte dos ocupantes do Poder Executivo, de que a burocracia internacional esteja mais insulada do ambiente político doméstico do que a burocracia doméstica.

Este argumento é a base de diversos estudos que argumentam que a delegação pode ser usada para implementar reformas econômicas ou garantir transições democráticas. Moravcsik (2000) propõe que a adesão de democracias recentes a corpos judiciais 
internacionais de direitos humanos são uma forma de governos nacionais consolidarem instituições democráticas internas:

Normas de direitos humanos são expressões do auto-interesse de governos democráticos de "travar" o regime democrático por meio da garantia de direitos humanos. Ao colocar a interpretação [destas normas] nas mãos de autoridades independentes geridas em parte por governos estrangeiros - em outras palavras, ao ceder soberania em favor de um corpo internacional - os governos buscam estabelecer restrições judiciais confiáveis sobre futuros governos não democráticos ou sobre governos democraticamente eleitos que possam tentar (como na Itália e na Grécia do entreguerras) subverter a democracia por dentro. (2000, p. 228.)

Na mesma linha, Mansfield e Pevehouse (2006) sugerem que

Entrar numa OI pode ajudar os líderes de Estados em transição a comprometer-se de forma crível a levar a cabo reformas democráticas, e pode reduzir a possibilidade de reversões ao autoritarismo, especialmente se a organização for composta principalmente por membros democráticos (p. 138).

O problema da credibilidade dos compromissos é particularmente importante no que tange a reformas econômicas. Há uma grande literatura, baseada na abordagem de expectativas racionais, que recomenda a delegação da política monetária a um banco central independente como forma de reduzir a inflação ${ }^{19}$. O mesmo raciocínio tem sido usado para explicar como a delegação para organizações internacionais pode acelerar — ou até mesmo tornar possível - a adoção de reformas econômicas liberalizantes. Brune, Garrett e Kogut (2004), por exemplo, afirmam que países que têm dívidas com o FMI detêm um "bônus de credibilidade", porque investidores vêem as cláusulas de condicionalidade dos empréstimos do Fundo como um sinal de compromisso do governo do país devedor com reformas. Este "bônus de credibilidade", por seu turno, facilita os processos de privatização, pois aumenta o valor que os investidores estão dispostos a pagar pelos ativos privatizados. Argumento similar é apresentado por Boughton (2005), que afirma que o FMI é importante para ajudar os países a adotar reformas econômicas, sinalizando o comprometimento de seus governos com estas reformas. Roland (2002), por seu turno, defende que a diferença entre a exitosa transição da Europa oriental para o capitalismo e a desastrada transição da ex-União Soviética se deve, em grande medida, ao fato de que os primeiros tinham a expectativa de juntar-se à União Européia, e portanto seu compromisso com as reformas liberalizantes possuía bastante credibilidade - inexistente no caso dos países resultantes da fragmentação da URSS.

\footnotetext{
${ }^{19}$ Cf. Bernhard, Broz e Clark (2002) para uma introdução à literatura pertinente.
} 


\subsection{A DELEGAÇ̃̃O DA CRISE DA DÍVIDA DOS ANOS 80 PARA O FMI}

$\mathrm{Na}$ sessão anterior, revisamos as motivações que levam os Estados a delegar autoridade a organizações internacionais. Nesta sessão, voltamo-nos para a relação particular entre Estados e OIs que é o objeto deste trabalho: a delegação da gestão da crise da dívida dos anos 80 para o Fundo Monetário Internacional.

O FMI foi criado na Conferência de Bretton Woods, de 1944, que desenhou a ordem econômica do pós-guerra. Os principais atores da conferência — os delegados britânicos e norte-americanos - compartilhavam a visão de que a intervenção estatal era necessária para promover a estabilidade e o progresso. A partir desta visão, foi montado um sistema relativamente aberto de comércio e pagamentos, com o objetivo de evitar a repetição dos desastres econômicos do entreguerras e conciliar abertura e expansão comercial com os compromissos dos governos nacionais com o pleno emprego e com a estabilização econômica.

O sistema de Bretton Woods baseava-se em taxas de câmbio semifixas, ajustáveis quando houvesse um "desequilíbrio fundamental". A idéia era explicitamente eliminar as políticas de "beggar-thy-neighbor" dos anos 30 e, ao mesmo tempo, evitar o grande problema do padrão ouro: a imposição de forte ajuste doméstico a um país que apresentasse desequilíbrio estrutural de balança de pagamentos. O sistema de câmbio semifixo de Bretton Woods permitia que desequilíbrios estruturais fossem resolvidos por meio de mudanças na taxa de câmbio, enquanto impedia que pequenos desajustes de curto prazo levassem a desvalorizações que causariam uma cascata de desvalorizações competitivas ou retaliatórias por parte dos outros países. Para auxiliar países que se encontrassem em desequilíbrios de curto prazo na balança de pagamentos, foi criado o Fundo Monetário Internacional. O Fundo também deveria evitar a ocorrência de desvalorizações competitivas (pois caberia a ele decidir quando um desequilíbrio de balança de pagamentos era "estrutural" e autorizar o país em questão a desvalorizar sua moeda), e promover a extinção dos controles cambiais e o estabelecimento de conversibilidade entre moedas (Bordo e James, 2000).

As mudanças no ambiente econômico nos anos 70 eliminaram a antiga razão de ser do FMI. A primeira mudança foi o fim do regime de taxas de câmbio fixas, em 1973, a partir do qual os países passaram a poder escolher livremente seu regime cambial. O FMI perdeu, assim, a função de zelar pelas regras do sistema monetário internacional. Os países industrializados adotaram regimes de câmbio flutuante, e assim praticamente eliminaram a 
necessidade de créditos de curto prazo em situações de desequilíbrio temporário da balança de pagamentos. Outra mudança fundamental foi a liberalização dos mercados financeiros internacionais. A partir dos anos 70, mesmo os países ainda em processo de industrialização (como México, Brasil e Argentina) passaram a contar com abundante financiamento privado oferecido pelos euromercados. Para o FMI, restou o papel marginal de emprestar para países mais pobres, acumular informações macroeconômicas sobre os países e desenvolver pesquisas com recomendações de política econômica.

O FMI tornou-se, assim, uma instituição em busca de uma missão. Mas as mesmas mudanças no ambiente econômico que o tornaram obsoleto nos anos 70 lhe ofereceriam a oportunidade de assumir um lugar central na economia internacional a partir dos anos 80. A liberalização dos mercados de capitais multiplicou o crédito acessível a tomadores soberanos. Isto aumentou a volatilidade do sistema como um todo, e o tornou mais propenso a grandes crises financeiras de alcance internacional.

A primeira destas crises se iniciaria em 1982, como resultado do fim abrupto do ciclo de endividamento dos países em desenvolvimento da América Latina causado pelo segundo choque do petróleo e pelo intenso aumento das taxas de juros dos EUA a partir de 1980. Naquele momento, o governo norte-americano, sob a presidência de Ronald Reagan, possuía uma posição programática de oposição a intervenções estatais e desconfiança com relação a organizações internacionais. Mesmo assim, o governo Reagan decidiu conferir ao FMI uma instituição cuja existência baseava-se numa visão oposta à das autoridades norteamericanas - o papel central nas negociações entre os países devedores e os bancos credores.

A atuação do FMI foi fundamental para enfrentar a crise e estabilizar o sistema financeiro. Em 1982, o total de créditos concedidos aos países em desenvolvimento pelos grandes bancos norte-americanos era maior do que o total de capital dessas instituições. Um default de pelo menos dois dos três grandes devedores (Argentina, Brasil e México) teria causado uma forte crise bancária nos EUA. O FMI impediu que tal crise ocorresse. As linhas de crédito do Fundo permitiram que os países devedores continuassem cumprindo seus compromissos com os bancos comerciais, que pouco a pouco reduziram sua exposição a esses países. Houve uma gradativa transferência de risco, dos bancos comerciais para as instituições multilaterais. Dessa forma, o FMI interviu no mercado financeiro internacional para impedir um colapso do sistema bancário norte-americano. 
Por que o governo dos EUA decidiu delegar a tarefa de gerenciar a crise financeira para o FMI? Por que não interviu diretamente para impedir uma crise bancária, preferindo agir por meio de uma organização internacional? No próximo tópico, serão apresentadas as explicações já oferecidas pela literatura. No tópico seguinte, será apresentada uma nova explicação, que procura complementar as já existentes.

\subsubsection{EXPLICAÇÕES OFERECIDAS PELA LITERATURA}

A partir das categorias analíticas apresentadas na primeira sessão, podemos perceber que as explicações que a literatura sobre crises financeiras oferece para a delegação ao FMI dividem-se entre aquelas que sublinham que o FMI facilita a adoção de reformas econômicas por parte dos países devedores e aquelas que afirmam que o FMI permite ao hegemon do sistema (os EUA) obter a participação dos outros países industrializados. Desta forma, a delegação para o FMI tornaria a gestão das crises menos onerosa para os EUA.

A explicação mais simples e tradicional encontrada na literatura é que o FMI assumiu o papel de gestor de crises financeiras quase por acaso. Em 1982, por ocasião da crise da dívida dos países da América Latina, teria assumido papel central porque era a instituição que podia mobilizar os recursos necessários para a estabilização mais rapidamente do que outras entidades ou arranjos ad hoc entre os Estados (Boughton, 1997, p. 17, Bordo e James, 2000, p. 37). Para Boughton (1997), em 1982 o FMI era "a única instituição com autoridade e recursos para reagir rapidamente" à ameaça de default do México (p. 17). O FMI teria apenas conseguido, em 1982, oferecer uma solução adequada; como não havia outras, ela foi aceita pelos países industrializados.

Outra linha de argumentação sustenta que o FMI seria a forma mais eficiente de levar os países devedores a empreenderem ajustes macroeconômicos que lhes permitiriam recuperar a capacidade de pagar o serviço de suas dívidas. Reconhecendo este fato, os países desenvolvidos - especialmente os Estados Unidos — delegariam ao Fundo a gestão das crises financeiras internacionais. Desta forma, o FMI seria "um condutor conveniente de influência dos EUA", como afirmou um alto funcionário norte-americano (Cohen, 1985, p. 722). Como afirmou o então secretário do Tesouro, Donald Regan, em 1983, “o FMI é central para a estratégia de lidar com os problemas atuais de maneira a apoiar os interesses econômicos e de política externa dos EUA" (Parola, 1991, p. 52). 
A motivação declarada do governo norte-americano para seu apoio ao FMI como gestor das crises financeiras internacionais é sua capacidade de impor condicionalidades aos seus empréstimos aos países em desenvolvimento. Segundo Regan, "a principal razão pela qual o FMI tem um papel tão central em nossa estratégia é a condicionalidade associada aos seus empréstimos" (Parola, 1991, p. 55).

Para liberar os créditos aos países em desenvolvimento, o FMI exige que estes se comprometam a ajustar suas economias de maneira a atingir determinadas metas macroeconômicas. Técnicos do FMI auditam as contas nacionais e determinam se as metas foram atingidas ou não; em caso negativo, o FMI pode interromper a concessão de novos créditos.

Segundo este argumento, a principal vantagem do FMI seria a capacidade que ele possuiria de impor condições aos países devedores e verificar seu cumprimento. Por ser uma organização internacional alegadamente técnica, ao FMI seria permitido um grau de ingerência na economia dos países devedores que não seria possível a qualquer país industrializado, nem mesmo aos EUA (Swedberg, 1986).

$\mathrm{Na}$ mesma linha, outra explicação é que os governos dos países devedores, reconhecendo a necessidade de realizar ajustes econômicos dolorosos e politicamente difíceis, precisariam do FMI como forma de vencer a oposição interna aos ajustes. Segundo esta linha de raciocínio, a organização internacional seria usada pelos países devedores para legitimar as reformas no plano interno e reduzir a capacidade de oposição dos atores domésticos que mais seriam prejudicados por elas (Vreeland, 2004). A assinatura de um acordo com o FMI atribuiria o poder de agenda sobre as reformas econômicas para uma entidade externa ao sistema político do país devedor; agruparia todas as medidas de reformas em um único pacote que deveria ser integralmente cumprido, sob pena de perda do acesso ao crédito do Fundo; criaria assimetrias de informação, pois a opinião pública nacional não teria meios para determinar quais medidas foram impostas pelo Fundo e quais medidas foram propostas pelo governo nacional; e aumentaria a legitimidade do pacote de ajuste, pois ele estaria sendo executado com vistas a recuperar o acesso do país em questão ao mercado internacional de crédito e assim superar uma crise econômica.

Um argumento similar é o de que a assinatura de um acordo com o FMI aumentaria a credibilidade do compromisso dos países em desenvolvimento com reformas econômicas liberalizantes (Brune, Garrett e Kogut, 2004, Boughton, 2005). No curto prazo, tais reformas 
causariam prejuízos políticos que incentivariam os governos a abandoná-las. A existência de um programa de ajuste com o FMI aumentaria os custos do abandono das reformas, ajudando a "travar" a políticas reformistas e dificultando sua reversão, mesmo que o governo que as iniciou seja substituído por uma coalizão com preferências diferentes.

Finalmente, uma terceira vertente de explicação para a delegação dos EUA ao FMI é que ela reduziria o custo da gestão das crises financeiras para os EUA, em comparação com outras soluções possíveis. O FMI agrega recursos em moeda forte de todos os países industrializados, mas seu processo decisório concederia peso desproporcional às preferências dos EUA. Segundo Bordo e James, o FMI seria "uma maneira de projetar um modo particular de pensar sobre o mundo" que beneficia os EUA (2000, p. 38). O FMI permitiria que os EUA, como hegemon do sistema financeiro internacional, compartilhassem os custos da estabilização com os outros países desenvolvidos, sem perder o poder de implementar as políticas de sua preferência.

\subsubsection{UMA NOVA EXPLICAÇÃO: POLÍTICA DOMÉSTICA DOS EUA COMO DETERMINANTE DA DELEGAÇÃO AO FMI}

As explicações tradicionais modelam a crise da dívida como um processo de negociações sucessivas entre bancos credores e países devedores. Nesta perspectiva, o FMI teria, com o apoio dos países industrializados, atuado como intermediário, coordenando a ação coletiva dos bancos e evitando que os devedores se unissem e formassem um cartel.

Estas explicações tendem a ver os governos, tanto dos países industrializados quanto dos países devedores, como atores unitários. Algumas poucas explicações abrem mão do pressuposto do Estado unitário quando procuram explicar o papel do FMI como promotor de reformas nos países devedores. Mas nenhuma delas se propõe a entender as motivações que a política doméstica norte-americana ofereceu para a delegação ao FMI. Este trabalho propõe justamente isto.

O ponto de partida da tese proposta neste trabalho é que a crise da dívida não foi apenas uma questão de política internacional, mas foi também um problema de política doméstica dos EUA com repercussões na sua política externa. Esta perspectiva coloca os EUA no centro da crise. Os bancos que mais emprestaram aos países subdesenvolvidos, no processo de reciclagem de petrodólares dos anos 70 que está na raiz do problema, foram os 
sete grandes bancos norte-americanos (os money center banks ${ }^{20}$ ). Quando a crise da dívida eclodiu, estes bancos estavam altamente expostos à dívida dos países subdesenvolvidos ${ }^{21}$, e um default destes devedores poderia levá-los à falência. Os grandes bancos dos outros países industrializados estavam menos vulneráveis, pois haviam emprestado menos. A crise da dívida ameaçava, principalmente, o próprio sistema bancário norte-americano. A crise bancária exigiria que um emprestador de última instância entrasse em ação, provendo a liquidez (em dólares) necessária para manter o sistema financeiro em funcionamento e evitar uma crise com conseqüências similares à de 1929. Ora, a única entidade que pode imprimir dólares é o Federal Reserve; sobre ele cairia a responsabilidade de salvar o sistema. Se um dos grandes bancos norte-americanos estivesse sob risco de quebrar, o Fed teria de bombear os dólares necessários para evitar sua falência. Uma consequiência negativa desta intervenção — necessária e inevitável em caso de default dos principais devedores soberanos — seria uma alta na inflação, causada pelo grande aumento na oferta monetária que a injeção de liquidez no mercado causaria. O governo norte-americano, evidentemente, preferiria que a situação não se deteriorasse a este ponto, mas, se o fizesse, ele estava pronto para agir, mesmo que à custa de mais inflação: "seria um imposto para salvar o sistema", como afirmou um funcionário do governo à época (Palmer, 1983).

Uma alternativa puramente doméstica a esta catástrofe do sistema bancário seria a compra, por parte dos bancos centrais dos países desenvolvidos, das dívidas soberanas em mãos dos bancos. Como afirmou Alan Greenspan em 1982, o mercado de ouro subiu rapidamente logo após a eclosão da crise da dívida, porque temia-se que os governos dos países desenvolvidos - particularmente os EUA — fossem obrigados, para evitar uma crise bancária, a comprar estes débitos, o que também aumentaria a oferta monetária e, portanto, causaria inflação (Byron, 1982).

Uma variante deste curso de ação seria um aumento súbito e expressivo no volume de empréstimos oficiais dos países desenvolvidos para os subdesenvolvidos, de maneira a substituir a oferta de crédito dos bancos comerciais. Seria uma rápida operação de salvamento, por meio da qual, em poucos meses, os bancos reduziriam sua exposição à dívida

\footnotetext{
${ }^{20}$ Os sete money center banks à época eram Citibank, BankAmerica, Manufacturers Hanover, Chase Manhattan, J.P. Morgan, Chemical e Bankers Trust (Madrid, 1992).

21 "Exposição" é a porcentagem do patrimônio líquido de um banco que está comprometido com empréstimos a um devedor ou grupo de devedores. Estimava-se que o total que os nove maiores bancos dos EUA emprestaram para Argentina, México e Brasil correspondiam a 130\% de seu capital total (Palmer, 1983). Caso estes três devedores parassem de pagar os juros e suas dívidas tivessem de ser contabilizadas como perdas, estes bancos passariam a ter patrimônio líquido negativo e certamente teriam de ser salvos pelo Federal Reserve.
} 
soberana, e o problema de cobrar os países devedores passaria para os governos dos países desenvolvidos 22 .

No entanto, não havia clima político interno para uma operação de salvamento rápido. Boa parte dos congressistas, desde o início da crise, mostrou-se refratária a qualquer movimento neste sentido, preferindo que os bancos assumissem as consequiências de suas próprias decisões, “como qualquer outra empresa" (Lissakers, 1991, p. 191, Parola, 1991, pp. 53-55). Se os bancos fizeram empréstimos a devedores sem condições de pagá-los, nada mais natural que pagassem pelo seu erro. Como um dos poderes mais importantes do Congresso é o poder de alocar recursos orçamentários, qualquer iniciativa que dependa de grande quantidade de recursos deve necessariamente ser aprovada por ele. O poder da bolsa colocava o Congresso, na prática, no papel de veto player de qualquer estratégia de estabilização do sistema financeiro que fosse tentada diretamente pelo Executivo norte-americano.

O que este trabalho sustenta é que, a despeito da oposição do Congresso, o governo norte-americano de fato empreendeu uma operação de salvamento - mas, para reduzir a influência do Legislativo e conseguir executar sua operação, o fez por meio do FMI. Usando o FMI como intermediário, o Poder Executivo conseguiu contornar a oposição do Congresso e logrou gerir a crise de acordo com suas preferências.

Ao delegar a gestão da crise financeira para o FMI, o governo retirou-a do plano da política doméstica, tornando-a uma questão exclusivamente de política internacional. Seguindo a tipologia de Moravcsik, esta manobra atuou de quatro formas. Primeiro, deslocou o poder de agenda para o FMI, impedindo iniciativas do Congresso sobre o tema. Segundo, impediu que o Legislativo ditasse diretrizes para o processo negociador ou analisasse e julgasse, individualmente, os planos de reescalonamento assinados com cada país devedor; a única opção deixada ao Congresso foi aprovar ou rejeitar, num único pacote, o grande aumento das quotas do FMI proposto pelo Tesouro em 1983. Terceiro, dificultou ou mesmo impediu o acesso, por parte do Congresso, de diversas informações, já que o FMI, como pessoa de Direito Internacional, não responde ao Congresso. Quarto, criou um arcabouço ideológico que justificava a operação de salvamento como uma forma politicamente neutra e pretensamente técnica de manter a ordem econômica internacional liberal do pós-guerra, caracterizada pelos fluxos relativamente livres de comércio e investimento internacionais.

\footnotetext{
${ }^{22}$ Dooley (1994) chega a sustentar que, dado o incentivo que o governo dos EUA tinha dado para que os bancos comerciais fossem protagonistas na reciclagem de petrodólares, estes tinham motivos para crer que seus
} 
A solução oferecida pelo FMI era mais lenta do que um salvamento puro e simples, mas tinha a vantagem de enquadrar a questão no plano mais estreito da política internacional. Os países devedores continuariam a pagar os juros da dívida, mesmo que, para isso, tivessem de receber sucessivos empréstimos oficiais para complementar a rolagem da dívida bancária. Enquanto a dívida externa dos 17 países em desenvolvimento mais endividados ${ }^{23}$ subiu de US\$ 392 bilhões em 1982 para US\$ 528 bilhões em 1990 (um aumento de 35\%), os empréstimos comerciais a esses países oscilaram, no mesmo período, de US\$ 219 bilhões para US\$ 232 bilhões — um aumento de apenas 6\% (Cline, 1995, pp. 40-41, 61). Desta forma, a participação dos empréstimos privados no endividamento total destes 17 países caiu de 56\% em 1982 para 44\% em 1990. Enquanto a dívida externa dos países em desenvolvimento pulou de US\$ 647 bilhões em 1982 para US\$ 1,018 trilhão em 1990 (Cline, 1992, p. 40-41), os empréstimos de longo prazo dos bancos comerciais mantiveram-se praticamente constantes, oscilando de US\$ 247 bilhões em 1982 para US\$ 245 bilhões em 1990 (Cline, 1995, pp. 62-63). A exposição dos nove maiores bancos norte-americanos ao Terceiro Mundo caiu de assustadores 255\% do seu capital em 1982 para confortáveis 79\% em 1990 (Cline, 1995, pp. 74-75).

Note-se que mesmo esta estratégia "internacional" tinha repercussões domésticas. Os planos de estabilização do FMI exigiam que os países devedores desvalorizassem suas moedas frente ao dólar para deixarem de ser importadores líquidos e tornarem-se exportadores líquidos. Isto reduzia os mercados externos para produtos norte-americanos, aprofundando a perda de competitividade externa e o consequiente déficit comercial causados pelo aumento de juros e pela alta do dólar desde 1979. Em resposta, a partir de 1985 formouse, no Congresso, uma coalizão protecionista que conseguiu obter concessões do Executivo em política comercial - mas a gestão da crise dívida, insulada pela delegação ao FMI, permaneceu intocada ${ }^{24}$.

Evidentemente, este argumento não teria sentido se o gerenciamento da crise da dívida fosse delegado a uma organização refratária às preferências do Poder Executivo norteamericano. O estudo aqui proposto mostrará que isto não ocorreu. Ao contrário, o FMI era bastante sensível às preferências do Departamento do Tesouro e do Federal Reserve, tanto no

\footnotetext{
empréstimos soberanos continham uma garantia implícita do governo norte-americano e, por isso, esperariam um salvamento rápido.

${ }^{23}$ Os 17 países em questão são Argentina, Bolívia, Brasil, Chile, Colômbia, Costa do Marfim, Costa Rica, Equador, Filipinas, Iugoslávia, Jamaica, Marrocos, México, Nigéria, Peru, Uruguai e Venezuela.

${ }^{24}$ Para o conflito no Congresso sobre política comercial, cf. Shoch (1998).
} 
que diz respeito ao relacionamento com os bancos - que deveriam continuar emprestando para minimizar o impacto da operação de salvamento sobre as contas públicas — quanto com os países devedores, já que as condicionalidades exigidas pelo Fundo podiam ser usadas para extrair reformas econômicas prescritas pelo pensamento econômico do governo Reagan.

Finalmente, embora pretenda lançar luz sobre a influência que a dinâmica doméstica tem sobre a delegação para organizações internacionais, este trabalho não tentará argumentar que considerações do plano internacional não tenham tido nenhuma influência na decisão de conceder ao FMI um papel protagônico na crise da dívida. Em primeiro lugar, não é possível descartar que fatores como a necessidade de compartilhar os custos da estabilização com os outros países industrializados ou a possibilidade de obrigar os países da América Latina a realizarem reformas liberalizantes tenham contribuído para a decisão dos EUA de delegar a gestão da crise ao FMI. Em segundo lugar, impedir que o poder legislativo interfira sobre determinada política pode também ser uma estratégia para impedir que atores externos exerçam influência em sua formulação e para sinalizar-lhes que esta política é a única forma segundo a qual um determinado regime será gerido. Em outros termos, pode-se aventar que a delegação da crise ao FMI tenha servido para aumentar a credibilidade do compromisso do hegemon com uma forma particular de estabilizar o sistema financeiro internacional. Este fato teria duas consequiências importantes. A primeira seria sinalizar aos devedores que de nada adiantaria tentar obter apoio na opinião pública norte-americana para mudar a estratégia de gerenciamento da crise, pois esta não seria mais objeto de deliberação. A segunda seria indicar aos outros países desenvolvidos que deveriam coordenar suas políticas para a crise (que envolviam, por exemplo, seus créditos para os países subdesenvolvidos e seus investimentos nestes países) de acordo com a política adotada pelo FMI, pois mesmo uma grande reviravolta política no Congresso não seria capaz de reverter a estratégia adotada pelo Poder Executivo. 


\section{Atores institucionais}

Este capítulo apresenta os principais atores institucionais envolvidos nos episódios de crises financeiras internacionais: o Congresso, o Departamento do Tesouro, o Federal Reserve e o FMI. O objetivo é identificar os poderes e os limites à atuação internacional de cada ator, bem como entender sua estrutura de preferências.

Todos os atores são considerados unitários e racionais. Isto significa que eles possuem uma única estrutura de preferências e são capazes de avaliar, dentre um conjunto de alternativas, qual maximiza sua utilidade. Para o Tesouro, o Federal Reserve e o FMI - que possuem estruturas hierárquicas bem definidas —, assume-se que as preferências são manifestadas pelo principal tomador de decisão sobre a matéria: o secretário do Tesouro ou, no limite, o presidente dos EUA, no caso do Tesouro, o presidente do Conselho, no caso do Federal Reserve, e o diretor-gerente, no caso do FMI. No caso do Congresso, este pressuposto é mais problemático. Mesmo assim, como mostra Milner (1997, p. 35), é possível adotá-lo porque, para os objetivos desta análise, o interesse é determinar se o Congresso votará contra ou a favor de determinada proposição apresentada pelo governo. Para isto, considera-se que as preferências do Congresso são expressas pelo "eleitor mediano", ou seja, aquele cujas preferências estejam exatamente no centro das preferências do conjunto de congressistas.

Esta análise pressupõe que os atores são office-seekers, ou seja, sua prioridade é manter, e se possível ampliar, seu poder político. Embora estes atores possam ter preferências quanto a políticas públicas, eles só estarão em condições de executá-las se permanecerem no poder. Para os atores eleitos (membros do Congresso, presidente dos EUA e, por extensão, os integrantes de seu gabinete) a condição fundamental é vencer as eleições que disputarem. Desta forma, podemos afirmar que o objetivo dos atores eleitores é manter, e se possível ampliar, seu apoio junto ao eleitorado. Isto se reflete em estratégias diferentes para o Executivo e para o Legislativo. O titular do Executivo disputa eleições em nível nacional; assim, pode-se afirmar que a prioridade da área econômica do governo é manter um bom nível de crescimento econômico nacional e evitar a inflação. Nesse sentido, uma crise econômica tende a reduzir o apoio do presidente junto ao eleitorado, e aumenta o risco de que ele não consiga reeleger-se ou, quando isto for proibido, eleger um sucessor de sua 
preferência (Milner, 1997, pp. 33-35). Os membros do Congresso, por outro lado, disputam eleições em seus distritos. Para eles, portanto, a condição essencial para se manterem em seus cargos é garantir o apoio dos eleitores de seus distritos, mesmo que à custa de defender posições impopulares no plano nacional. Por isso, os congressistas estarão mais preocupados em assegurar benefícios tangíveis para seus distritos do que em apoiar iniciativas tendentes a melhorar o bem-estar em nível nacional. Quando o bem-estar nacional estiver em conflito com o bem-estar de seus distritos, os membros do Congresso tenderão a dar prioridade ao estes últimos - onde, afinal, estão seus eleitores. Isto implica que as preferências do congressista mediano (aquele cujas preferências, como vimos, expressam as preferências do conjunto do Congresso) não são, necessariamente, iguais às do Executivo.

Os atores burocráticos (Federal Reserve e FMI) também maximizam utilidade. Esta análise pressupõe que os dirigentes das burocracias também são office-seekers, ou seja, sua primeira prioridade é manter o poder de sua organização e continuar a dirigi-la. Ademais, eles também possuem suas próprias preferências sobre as políticas públicas a serem executadas nos temas sob sua responsabilidade. Procurarão, portanto, executar suas tarefas de acordo com suas preferências, desde que isto não lhes custe a perda do cargo ou a redução do poder de suas burocracias. Em outros termos, como são agentes, os atores burocráticos devem ter em conta as preferências dos principais que a eles delegam suas tarefas, mas também possuem preferências próprias e, por isso, seu comportamento não refletirá exatamente as preferências dos principais.

O capítulo começa com uma avaliação do Congresso e de seus poderes em política externa. Esta seção sustenta que o principal instrumento político do Congresso nessa matéria é o seu poder de apropriar fundos. A seguir, é apresentado o Departamento do Tesouro como responsável, no âmbito do poder Executivo, pela manutenção da estabilidade financeira internacional. Depois, o capítulo analisa a estrutura e os intrumentos à disposição do banco central norte-americano, o Federal Reserve. Por fim, o capítulo apresenta a estrutura do Fundo Monetário Internacional. Nesta seção, defendo a tese de que o Executivo norte-americano influi decisivamente nas decisões deste organismo. A seção também apresenta uma avaliação dos instrumentos à disposição do Congresso para influenciar diretamente o FMI, e conclui que eles são bastante limitados. 


\subsection{O CONGRESSO E O CONTROLE SOBRE O EXECUTIVO}

O sistema de freios e contrapesos criado pelos "Pais Fundadores" dos Estados Unidos estabeleceu uma estrutura no qual o poder é fragmentado e descentralizado. Os legisladores que criaram a Constituição queriam limitar o poder, e por isso dividiram a autoridade entre os diversos ramos do governo. O Executivo federal é dividido em diversas agências, cuja existência depende de aprovação do Congresso. O próprio Congresso, por sua vez, é dividido: além de ser bicameral, o trabalho em cada câmara é dividido em comissões e subcomissões.

A Constituição garante ao Congresso a autoridade exclusiva para legislar, para criar impostos e para autorizar gastos. Esta última autoridade é um dos pilares do poder do Congresso. Geralmente conhecida como o "poder da bolsa", ela está expressa no Artigo 1ํㅡ, seção 9: "Dinheiro algum poderá ser retirado do Tesouro senão em consequiência da dotação determinada em lei" ${ }^{25}$. Este dispositivo, segundo o qual todos os gastos federais dependem de autorização prévia do Legislativo, limita a autonomia do Executivo para executar suas políticas, tanto no nível interno quanto no nível externo.

O processo orçamentário é dividido entre autorização e apropriação. Atos de autorização estabelecem, mantêm e modificam agências ou programas federais. $\mathrm{O}$ ato de autorização também determina a quem a agência ou programa será subordinada. Por exemplo, o Foreign Assistance Act de 1961 autorizou a criação da USAID, subordinada ao Departamento de Estado, enquanto o Homeland Security Act de 2002, que criou o Departamento de Segurança Interna (DHS), modificou e subordinou a ele uma série de agências federais que antes reportavam-se a outros departamentos ${ }^{26}$. Os atos de apropriação, por seu turno, autorizam as agências e programas já autorizados a contrair compromissos, e permite que o Tesouro faça os pagamentos necessários para cumpri-los. Desta forma, uma agência ou programa deve primeiramente ser autorizada a funcionar, e depois ela deve receber uma apropriação de fundos.

Um ato de autorização pode explicitamente incluir a apropriação para a agência ou programa correspondente. Desta forma, simplifica-se o processo orçamentário. A apropriação, nestes casos, pode ser permanente, anual, ou plurianual. Apropriações anuais e plurianuais

\footnotetext{
${ }^{25}$ Tradução da Embaixada dos Estados Unidos da América em Brasília. Disponível em <http://www.embaixadaamericana.org.br/index.php?action=materia\&id=643\&submenu=106\&itemmenu=110>.

${ }^{26}$ Por exemplo, o antigo Immigration and Naturalization Service, subordinado ao Departamento de Justiça, foi dividido em U.S. Citizenship and Immigration Services, U. S. Border Patrol e U.S. Immigration and Customs Enforcement, todos subordinados ao Departamento de Segurança Interna. Da mesma forma, o Departamento do
} 
devem ser renovadas quando expiram, ao contrário das permanentes, que são garantidas nos anos subseqüentes até serem canceladas ou modificadas pelo Congresso. Os programas que concedem benefícios garantidos em lei à população (entitlements) são geralmente financiadas por meio de apropriações permanentes embutidas nos atos de autorização, de maneira a evitar que um impasse na negociação do orçamento anual interrompa a concessão dos benefícios.

O Congresso também pode rescindir uma apropriação, reduzindo ou eliminando os fundos disponíveis para determinado item do orçamento. O Congresso pode tomar iniciativa de rescindir uma apropriação, ou o presidente pode solicitar uma rescisão; em ambos os casos, a decisão final é sempre do Congresso.

O processo regular de autorização e apropriação dos gastos federais ocorre anualmente $^{27}$. Ele começa pelo Escritório de Administração e Orçamento (Office of Management and Budget, OMB), um órgão do Executivo, que, após negociar com as agências federais, elabora uma proposta de orçamento. Esta proposta do Executivo é enviada ao Congresso.

Até 1974, a proposta do Executivo era dividida entre as comissões que tratam de cada tema, e cada comissão trabalhava de forma independente. $\mathrm{O}$ orçamento era o resultado das diversas propostas aprovadas. Não havia, portanto, coordenação no âmbito do Legislativo. Em 1974, o Budget and Impoundment Control Act criou as comissões de Orçamento da Câmara e do Senado, para servir como instâncias de coordenação legislativa no processo de formulação do orçamento. Estas duas comissões estabelecem um limite geral de gastos federais, e determinam limites de gastos que cada uma das outras comissões poderão propor para o plenário. Desta forma, procurou-se conter o crescimento dos gastos públicos, que começou a acelerar-se nos anos 60. Embora este objetivo não tenha sido atingido ${ }^{28}$, as mudanças estabelecidas em 1974 aumentaram a capacidade de o Congresso responder à proposta orçamentária do Executivo. Isto aumentou o poder do Congresso no processo de formulação do orçamento, ao mesmo tempo em que intensificou o potencial de conflito entre os participantes.

Uma vez encerrado o processo de definição e aprovação do orçamento, o Congresso pode, para fazer frente a contingências, aprovar autorizações e apropriações suplementares.

\footnotetext{
Tesouro perdeu a autoridade sobre o Customs Service, o Secret Service e o Federal Law Enforcement Training Center, que passaram ao controle do DHS.

${ }^{27}$ A descrição que se segue do processo orçamentário baseia-se em Hartman (1982) e Streeter (2008).

${ }^{28}$ Sobre isso, Ferejohn e Krehbiel (1987). De qualquer forma, a lei refletiu a crescente preocupação dos congressistas com o aumento dos gastos públicos.
} 
As guerras do Iraque e do Afeganistão, por exemplo, foram financiadas desta maneira. As operações de salvamento financeiro (bailouts), por exigirem ação rápida do Executivo, são também financiadas por meio de apropriações fora do processo orçamentário regular. Por exemplo, o Troubled Asset Relief Program (TARP) de 2008, que autorizou o Tesouro a utilizar até US\$ 700 bilhões para comprar ativos "tóxicos" de instituições financeiras com o objetivo de fortalecer o sistema financeiro, requereu, para entrar em vigor, que fosse aprovada uma apropriação de fundos por parte do Congresso.

Os pedidos de apropriações suplementares são geralmente os momentos em que afloram os conflitos entre Congresso e Executivo sobre o orçamento. No processo orçamentário regular, o custo do não-acordo é alto - a paralisação do governo federal ou seu financiamento por meio de sucessivas continuing resolutions ${ }^{29}$, o que não é do interesse de nenhum dos participantes (Schick, 1975). Ademais, uma grande quantidade de propostas é apresentada conjuntamente, o que cria muitas possibilidades de troca de votos e compensações mútuas. Estes fatores induzem o debate público a concentrar-se em questionamentos amplos (e geralmente inconseqüentes) sobre a dimensão e a composição dos gastos públicos e o crescimento do déficit, mas desfavorecem discussões abertas sobre itens particulares do orçamento, pois tais itens são a moeda de troca usada pelo Executivo para angariar apoios entre os congressistas ${ }^{30}$. Em outros termos, a votação de diversas propostas em bloco que caracteriza o processo orçamentário regular incentiva o comportamento de reciprocidade entre os congressistas descrito por Mayhew (1974), pelo qual os parlamentares trocam entre si fundos federais (o chamado "pork-barrel") para seus distritos. Os debates sobre apropriações suplementares, por outro lado, abrem a possibilidade de se realizar discussões substantivas, e até profundas, sobre os méritos da proposta apresentada, geralmente acompanhadas de perto pela imprensa. Nestas ocasiões, os custos do não-acordo são baixos para os congressistas, pois a rejeição do pedido terá efeito sobre apenas o programa federal em discussão. Se o Executivo não conseguir convencer que o programa

\footnotetext{
${ }^{29}$ Uma continuing resolution apropria fundos temporários para as operações já estabelecidas, com base no último orçamento, mesmo sem a existência de um orçamento aprovado. Esta solução, no entanto, além de congelar o financiamento do governo federal no patamar do ano anterior, é altamente ineficiente, pois a incerteza sobre o volume de recursos que estará disponível no orçamento do ano leva os administradores públicos a, no primeiro momento, conter excessivamente os gastos e, uma vez que o orçamento definitivo seja aprovado, a gastar os fundos apropriados de forma excessivamente rápida, para evitar sobras e uma conseqüente redução no orçamento seguinte.

${ }^{30}$ Para um exemplo deste efeito, cf. Greider (1981), que descreve o processo de elaboração do primeiro orçamento do presidente Reagan. Como resumiu o então diretor do Office of Management and Budget, David Stockman, "neste tipo de jogo, todo mundo pode exigir um preço alto por um voto".
} 
proposto é essencial para o país, os congressistas terão fortes incentivos para rejeitar o pedido de apropriação com o argumento de que estão protegendo o "dinheiro do contribuinte". Desta forma, estes pedidos oferecem amplas oportunidades para congressistas posarem como paladinos da austeridade e criticarem a ineficiência, o desperdício e o abuso dos programas federais.

As operações de salvamento financeiro montadas pelo Executivo são exemplos marcantes de como um pedido de verbas suplementares pode mobilizar o Congresso. Em quatro ocasiões entre 1970 e 1979, o governo federal decidiu conceder empréstimos extraordinários para salvar entidades em dificuldades (Penn Station em 1970, Lockheed em 1971, cidade de Nova York em 1975 e Chrysler em 1979). Em todas as ocasiões, o governo precisou apresentar ao Congresso pedidos de apropriação suplementar, cujos valores eram irrisórios em comparação com o total dos gastos ou mesmo do déficit federal. Mesmo assim, estes pedidos passaram por longos e desgastantes processos de negociação, envolvendo lobistas, executivos, sindicalistas, autoridades do governo e congressistas dos distritos que seriam mais afetados pela eventual falência. Os pedidos nem sempre foram aprovados - o Congresso rejeitou a proposta de salvamento da Penn Station, que acabou falindo pouco depois - e, mesmo quando a Casa Branca conseguiu a aprovação legislativa, os salvamentos custaram-lhe caro em termos de capital político. Invariavelmente, os processos de negociação de salvamento expuseram o Executivo a críticas de que estaria injustamente beneficiando determinados setores ou favorecendo grandes empresas, e assim impedindo o funcionamento do livre mercado ${ }^{31}$.

\subsubsection{O PAPEL DO CONGRESSO EM POLÍTICA EXTERNA}

Em política externa, o Executivo tem tradicionalmente mais autonomia vis-à-vis o Legislativo do que em política doméstica. Ainda assim, o "poder da bolsa" confere ao Congresso a possibilidade de influenciar quase todas as iniciativas da Casa Branca.

A Constituição divide a autoridade sobre a política externa entre Legislativo e Executivo. O texto constitucional confere extensos poderes para o Congresso sobre a matéria. Segundo o Art. 1ํำ da Seção 8, cabe ao Congresso "prover a defesa comum", "regular o comércio com nações estrangeiras", "definir e punir pirataria e crimes cometidos em altomar", "declarar guerra", "estabelecer e manter exércitos", "prover e manter uma marinha", e

\footnotetext{
${ }^{31}$ Para um exemplo, cf. a análise de Freeman e Mendelowitz (1982) do salvamento da Chrysler em 1979.
} 
"fazer regras para o governo e regulamentação das forças terrestres e navais". O Art. 2 da Seção 2 estabelece que o Senado deve dar seu "conselho e consentimento" a todos os tratados e às nomeações de embaixadores. Ademais, os poderes gerais do Congresso de apropriar recursos e confirmar as nomeações para os cargos de nível ministerial também conferem possibilidades adicionais para o Legislativo influenciar a política externa. Ao presidente, por seu turno, cabe conduzir a política externa. É o presidente que negocia com outros Estados, e é a ele que se reportam as burocracias diretamente envolvidas no dia-a-dia da política externa. Ademais, ele é comandante-em-chefe das Forças Armadas.

Como tanto o Congresso quanto o presidente têm autoridade constitucional sobre a política externa, a questão relativa a qual deles deveria prevalecer quando há um conflito entre os dois poderes é objeto de disputa desde os primeiros anos de existência dos Estados Unidos. Com o tempo, o Executivo acumulou cada vez mais poder sobre a política externa, em detrimento do Legislativo. Um ponto de inflexão nesta disputa foi a decisão da Suprema Corte no caso U.S. vs Curtiss-Wright Corporation, de 1934, que estabeleceu uma distinção fundamental entre os poderes do presidente em assuntos domésticos e externos: os poderes de soberania externa não estariam limitados pela Constituição, e eles cabiam ao presidente, a única instância do governo federal capaz de atuar no campo das relações exteriores. Em outros termos, a decisão da Suprema Corte "afirmou [em política externa] a existência de um poder presidencial inerente, independente e superior, não derivado da Constituição e que não requer legislação como base de seu exercício" (Schlesinger, 1973, pp. 102-103). No ano seguinte, a Suprema Corte aumentaria ainda mais os poderes do presidente, ao remover, na decisão do caso U.S. vs. Belmont, os limites à aplicação de acordos executivos, o que abria a possibilidade de o Executivo negociar acordos com governos estrangeiros sem a aprovação, a participação ou mesmo o conhecimento do Congresso.

A preponderância do Executivo sobre a matéria atingiu o auge entre a Segunda Guerra Mundial e a Guerra do Vietnã. Pressionado a atuar decisivamente em favor da Inglaterra, Franklin Roosevelt emprestou dezenas de navios de guerra aos ingleses sem a aprovação do Congresso, e assinou o acordo lend-lease com este país por meio de acordo executivo. $\mathrm{O}$ início da Guerra Fria consolidou a preponderância do presidente. O medo da expansão soviética levou democratas e republicanos e estabelecerem a chamada "política externa bipartidária", na qual o Congresso atuava essencialmente em consonância com o presidente. Este consenso entre as lideranças dos partidos permitiu que os sucessivos presidentes 
vencessem uma longa tradição de isolacionismo (que havia impedido, por exemplo, a adesão dos EUA à Liga das Nações) e conseguissem a aquiescência do Congresso para a criação da ONU e da OTAN, para o plano Marshall, para a intervenção no Vietnã, para o tratado de banimento de testes nucleares, para a política de détente, para o acordo SALT e para o reconhecimento da China comunista ${ }^{32}$. A política comercial também ficaria a cargo do presidente, em grande medida porque o Congresso passou a ser associado ao protecionismo dos anos 30, visto como uma das causas da Grande Depressão e da II Guerra ${ }^{33}$. A partir dos anos 70, a reação ao fracasso no Vietnã e as reformas no funcionamento do Legislativo romperiam o consenso bipartidário e levariam o Congresso a tornar-se mais assertivo em política externa. Mesmo assim, o presidente continuou a ser o ator preponderante na formulação da política externa norte-americana.

Mas mesmo nos períodos de maior preponderância do presidente em política externa, o "poder da bolsa" permitiu que Congresso mantivesse grande influência em pelo menos um tema de grande importância: a concessão de ajuda internacional, tanto na vertente de ajuda militar, quanto na de ajuda para o desenvolvimento.

Como todos os recursos para as atividades de ajuda internacional dependem de apropriação do Congresso, este se encontra em posição central para influenciá-las. A grande influência no tema de ajuda internacional levou o Congresso até mesmo a negligenciar outros assuntos; como um integrante da Comissão de Assuntos Estrangeiros da Câmara confidenciou a Richard Fenno nos anos 60, "na verdade, nós somos uma espécie de comissão de ajuda internacional. Nós temos outras leis, e eu não quero subestimar a importância da Agência de Controle e Desarmamento ou do Peace Corps. Mas eles não são o tipo de leis nas quais se passa seis meses trabalhando" (Fenno, 1973, p. 69, apud Pastor, 1980, p. 252).

Como mostra Pastor (1980), o Congresso mostra uma disposição em influir na temática de ajuda internacional que não se manifesta normalmente em outras áreas da política externa. Isto ficaria evidente desde as discussões do Plano Marshall. Para administrar os recursos do plano, o Comitê de Relações Exteriores do Senado, e em particular seu

\footnotetext{
${ }^{32}$ A literatura sobre o relacionamento entre o presidente e o Congresso em política externa neste período é bastante ampla. Dois pontos de partida essenciais são os trabalhos de Schlesinger (1973) sobre o que denominou de "presidência imperial" e de Wildavsky (1966) sobre as "duas presidências", uma em assuntos domésticos e outra, na qual o presidente teria preponderância, em defesa e relações exteriores.

${ }^{33}$ Sundquist (1981) mostra que o Congresso delegou a política comercial ao presidente a partir de 1934, por meio do Reciprocal Trade Agreements Act, em grande medida para evitar que um surto protecionista levasse novamente a uma lei como a Smoot-Hawley de 1930, vista por muitos como uma das causas da Grande Depressão.
} 
presidente, o senador Arthur Vandenberg, criou a Administração de Cooperação Econômica (Economic Cooperation Administration, ECA), cujo presidente teria status igual aos dos membros do gabinete; como estes, seria indicado pelo presidente e deveria ser aprovado pelo Senado. Desta forma, a ECA não seria subordinada ao Departamento de Estado, como queria o secretário de Estado, George Marshall. Quando, posteriormente, o Washington Post relatou que o presidente Truman pretendia nomear o diplomata Will Clayton para presidir a ECA, Vandenberg opôs-se à indicação e propôs que o cargo fosse ocupado por um empresário. Truman cedeu e indicou Paul Hoffman, presidente da Studebaker (Pastor, 1980, pp. 262-263). Também foram incluídas na legislação diversas provisões que visavam a atender grupos de interesse, tais como a obrigatoriedade de que 50\% dos bens cedidos fossem transportados em navios norte-americanos (ibidem, p. 264).

Ano após ano, o Congresso usaria o "poder da bolsa" para pressionar as agências encarregadas da ajuda internacional a agir de acordo com suas preferências. Diversas exigências foram impostas, como cobrança de uma taxa mínima de juros em todas as operações, proibição da USAID de emprestar para países que se recusassem a assinar um acordo de proteção de investimentos com os EUA, restrições a vendas de armas para países estrangeiros, proibição de realizar operações com Indonésia, Índia e República Árabe Unida, e sanções a países que violassem direitos humanos, mesmo que fossem aliados dos EUA. A constante interferência do Congresso levaria o Executivo a tentar, repetidas vezes e sem sucesso, obter autorizações multi-anuais, de maneira a reduzir as oportunidades de o Legislativo influenciar os programas.

Finalmente, o Congresso pode usar o poder da bolsa para, cortando o financiamento para determinados programas, forçar mudanças na legislação. Ao recusar-se a apropriar fundos para um programa, o Congresso efetivamente o impede de funcionar, mesmo que o ato de autorização que o instituiu não seja cancelado. Este expediente, chamado legislation through appropriations, é considerado tortuoso na prática legislativa norte-americana, mas não é incomum. Foi, por exemplo, usado em 2009 para tornar inaplicáveis as restrições a viagens a Cuba instituídas pelo governo Bush em 2004. Sem revogar explicitamente as normas estabelecidas em 2004, o Omnibus Appropriations Act 2009 eliminou os fundos necessários para sua aplicação, transformando-a em letra morta. 


\subsection{O DEPARTAMENTO DO TESOURO}

O Poder Executivo é exercido pelo presidente dos Estados Unidos. Cabe a ele a última palavra em qualquer decisão tomada no âmbito do Executivo. No entanto, para nossa análise é mais útil considerar que o Poder Executivo é representado pelo secretário do Tesouro.

O departamento do Tesouro, assim como os departamentos de Estado e da Guerra, foi criado pela primeira legislatura do Congresso dos Estados Unidos, em 1789. Cabe ao Tesouro "administrar as finanças do governo dos EUA, promover o crescimento e a estabilidade econômica, e assegurar a segurança, a solidez e a estabilidade dos sistemas financeiros norteamericano e internacional" (Department of the Treasury, 2009).

O secretário do Tesouro é indicado pelo presidente dos EUA, e depende da aprovação do Senado para ser empossado. Em função do princípio da separação de poderes, a aprovação do Senado é irreversível, ou seja, o secretário de Estado (assim como os outros membros do gabinete) não pode ser demitido pelo Congresso, a não ser por meio de processo de impeachment por ter cometido algum crime. Desta forma, o secretário do Tesouro reporta-se hierarquicamente ao presidente, que pode demiti-lo a qualquer momento.

O Congresso, porém, detém o poder de reestruturar ou mesmo dissolver o Departamento do Tesouro, bem como as agências subordinadas a ele. Isto foi feito pela última vez em 2003, quando da criação do departamento de Segurança Interna, que assumiu o controle de diversas agências antes subordinadas ao Tesouro. O Congresso também conta com o poder de autorizar, modificar e extinguir as agências e programas do Departamento, assim como de apropriar os recursos orçamentários necessários para sua operação.

Para atuar no plano internacional, o Tesouro conta com um programa já autorizado pelo Congresso e que não precisa de apropriações periódicas: o Exchange Stabilization Fund.

\subsubsection{EXChANGE STABILIZATION FUND}

O Exchange Stabilization Fund (ESF) foi estabelecido pelo Gold Reserve Act de 1934, que conferiu ao Tesouro a responsabilidade primária pelas operações em moeda estrangeira dos Estados Unidos. O ESF iniciou suas operações em 27 de abril do mesmo ano, com um capital inicial de US\$ 2 bilhões em ouro, derivados do lucro contábil originado da reavaliação das reservas de ouro dos EUA de US\$20,67 para US\$ 35,00 a onça (Broaddus e Goodfriend, 1996, pp 1 e 10, Osterberg e Thomson, 1999, p. 1). Como o fundo precisaria de dólares para operar no mercado de câmbio, o equivalente a US\$ 200 milhões em ouro foram trocados por 
dólares com o Tesouro. Foi com este capital de apenas US\$ 200 milhões que o fundo começou a operar (Bloomfield, 1944, p. 70).

O objetivo declarado do ESF era estabilizar o valor do dólar no mercado de câmbio, comprando ou vendendo moedas estrangeiras. Um fator que motivou a criação do ESF foi a desconfiança das autoridades norte-americanas sobre os propósitos do Exchange Equalisation Account (EEA), estabelecido pelo Reino Unido em 1932. Embora o objetivo declarado do EEA fosse estabilizar o valor da libra, os norte-americanos desconfiavam que seu verdadeiro objetivo era depreciar a moeda britânica e, assim, promover as exportações do país (Schwartz, 1997, p. 137).

Em virtude da preocupação com o EEA, a lei que criou o ESF o cercava de sigilo e o isentava do processo de apropriação orçamentária do Congresso, bem como da supervisão legislativa. O fundo operaria sob o controle exclusivo do secretário do Tesouro, com a aprovação do presidente e sem precisar prestar contas ao Congresso (Osterberg e Thomson, 1999, p. 1, Schwartz, 1997, p. 137). Neste sentido, o ESF é um fruto típico do New Deal, no qual o Congresso basicamente aprovava as propostas legislativas do Executivo, que detinha iniciativa política. Como afirma Schwartz, "é difícil de acreditar que um fundo com poderes similares ganharia aprovação legislativa nos dias de hoje" (1997, p. 138).

O sigilo e o insulamento com relação ao Congresso tornavam o ESF um mecanismo extremamente flexível de intervenção governamental, usado para dois grandes propósitos. O primeiro é a intervenção nos mercados de câmbio para influenciar o valor do dólar vis-à-vis as outras moedas. O segundo é emprestar recursos para governos estrangeiros em dificuldades de balança de pagamentos. Este segundo uso do ESF foi o mais comum até 1961, e conferia ao Tesouro papel de formulador da política externa norte-americana. No período entre $1936 \mathrm{e}$ 1961, o Tesouro realizou, por meio do ESF, empréstimos para dez países da América Latina (Argentina, Bolívia, Brasil, Chile, Cuba, Equador, México, Nicarágua, Paraguai e Peru), bem como para a URSS, durante a II Guerra Mundial, e para a China, entre 1936 e 1943. Os recursos do ESF geralmente eram parte relativamente pequena de pacotes que envolviam outras agências, como o Export-Import Bank (Eximbank, que provê financiamento para o comércio exterior), a International Cooperation Administration e, a partir de 1961, a USAID (Schwartz, 1997, pp. 146-147).

Em 1961, o governo do recém-empossado presidente Kennedy, preocupado com a deterioração do balanço de pagamentos dos Estados Unidos, decidiu ampliar o ESF, para 
aumentar sua capacidade de atuação no combate à especulação contra o dólar. Entre janeiro e junho de 1961, o fundo comprou US\$105,5 milhões em libras esterlinas, marcos alemães e francos suíços. Como o capital total do fundo, naquele momento, era de US\$ 336 milhões, o Tesouro logo começou a procurar formas de aumentar os recursos disponíveis para ele.

Uma forma de aumentar o capital do ESF seria fazer saques da quota dos EUA no FMI, que em 1961 era de US\$ 6 bilhões. No entanto, o FMI dispunha de apenas US\$1,5 bilhão em moedas conversíveis além de dólares, e os EUA não poderiam sacar sua própria moeda. A solução encontrada foi o estabelecimento dos Arranjos Gerais de Tomada de Empréstimos (General Arrangements to Borrow, GAB), um mecanismo por meio do qual os bancos centrais dos países industrializados proviam ao FMI uma linha de crédito de cerca de US\$ 6 bilhões para assistir países em déficit. Na prática, o GAB era uma linha de crédito suplementar para os EUA, a ser usada para estabilizar o valor do dólar (Schwartz, 1997, pp. 140-141).

A partir de 1962, começa o chamado "armazenamento" (warehousing) de moeda estrangeira do ESF pelo Federal Reserve, que na prática servia como uma forma de o Federal Reserve financiar operações de compra de moeda estrangeira do Tesouro (Schwartz, 1997, pp. 141-142). Este procedimento permite que o ESF compre moeda estrangeira e a "armazene" no Fed, recebendo, em troca, dólares que serão usados pelo ESF para pagar o vendedor. A operação, na prática, é um financiamento do Fed a operações de compra de moeda estrangeira pelo ESF sem apropriação orçamentária aprovada pelo Congresso (Broaddus e Goodfriend, 1996, pp. 11-12, Humpage, 1994). Apenas algumas moedas podem ser "armazenadas" pelo Fed, de acordo com decisão do Conselho de Governadores do Federal Reserve System, assim como o montante máximo que pode ser "armazenado" pelo Fed é limitado pelo Federal Open Market Committee. Em 1977, o limite de "armazenamento" era de US\$ 1,5 bilhão, e em 1978 chegaria a US\$ 5 bilhões. Durante a crise mexicana de 1995, o teto seria elevado para US\$ 20 bilhões (Schwartz, 1997, p. 143).

No decorrer dos anos 60, sucessivos saques da quota norte-americana do FMI serviriam para aumentar o capital do ESF: US\$ 1,6 bilhão entre 1964 e 1966, US\$ 200 milhões em 1968, US\$ 1,7 bilhão entre 1970 e 1972, US\$ 3 bilhões em 1978 (ibidem, p. 143).

Outra fonte de financiamento do ESF foram as emissões de Direitos Especiais de Saque por parte do FMI. Os DES são uma moeda contábil, estabelecida pelo FMI em 1968 por meio da emenda à carta constitutiva da organização. Os EUA receberam o equivalente em 
DES a US\$ 2,29 bilhões entre 1970 e 1972, US\$ 870 milhões em 1977 e US\$ 1,73 bilhão entre 1980 e 1981 (Schwartz, 1997, p. 144). A legislação norte-americana que aprovou esta emenda determinou que os DES emitidos pelo FMI para os EUA deveriam ser detidos pelo ESF, que não poderia se envolver em nenhuma transação com outras agências do governo que reduzissem a quantidade de DES em seu poder. Uma manobra contábil chamada "monetização", porém, permitiu ao ESF utilizar os DES em suas operações: para converter DES em dólares, o ESF emite certificados designados em DES (os “certificados DES") que correspondem a um crédito sobre determinada quantidade de DES em poder do fundo. Por lei, o valor total de certificados DES emitidos pelo ESF não pode superar o total de DES em seu poder (Osterberg e Thomson, 1999, p. 2).

Como resultado da ampliação das fontes de financiamento, os ativos do ESF cresceram rapidamente a partir de 1961. Em 1960, os ativos somavam US\$ 330 milhões; em 1965, subiram para US\$ 517 milhões; em 1970, cresciam para US\$ 2,56 bilhões, em 1975 chegavam a US\$ 4,04 bilhões e, em 1980, atingiam US\$ 11,35 bilhões (Schwartz, 1997, p. 144). Ressalte-se que, em função do sigilo e da pouca transparência do ESF, é impossível saber o montante dos ativos disponíveis para aplicação, pois os dados relativos à quantidade de DES já "monetizados" e ao volume de moeda estrangeira "armazenada" pelo Fed não são de conhecimento público ${ }^{34}$.

A partir de meados dos anos 70, o Congresso passou a questionar o sigilo com o qual o Tesouro o impedia de tomar conhecimento das operações do ESF. Os congressistas começaram a ver no fundo uma forma de o Tesouro burlar os limites impostos pela legislação ao endividamento público (Osterberg e Thomson, 1996, p. 3). Por isso, o Legislativo tomou algumas medidas para aumentar a transparência do ESF. Em 1977, foi aprovada uma emenda à Seção 10 do Gold Reserve Act que estipulava que:

[...] um empréstimo ou crédito para uma entidade estrangeiro ou governo de um país estrangeiro pode ser feito por mais de seis meses em um período de 12 meses apenas se o Presidente expressar ao Congresso por escrito que circunstâncias únicas exigem que o empréstimo ou crédito tenha prazo superior a seis meses ${ }^{i}$ (31 U.S.C. 5302(b), apud Osterberg e Thomson, 1999, p. 1).

O ESF ficava, assim, caracterizado como um mecanismo financeiro de curto prazo. Em 1978, nova legislação passou a exigir que o Tesouro fornecesse relatórios mensais das operações do ESF às comissões de Bancos da Câmara e do Senado. Desta forma, era retirado o véu de sigilo que cobria o fundo, o que reduzia seu insulamento burocrático e aumentava as

\footnotetext{
${ }^{34}$ Para uma discussão sobre a diferença entre ativos totais e capital utilizável, cf. Osterberg e Thomson (1999).
} 
possibilidades de ingerência do Legislativo sobre sua operação. Em 1979, as despesas administrativas do ESF passaram a ser sujeitas ao processo normal de orçamento, o que mais uma vez aumentava a oportunidade de influência do Congresso sobre o fundo (ibid.).

Nos anos seguintes, os dirigentes do próprio Federal Reserve começariam a mostrar preocupação com o fato de que suas operações realizadas com o ESF poderiam constituir risco para o apoio do público à independência do Fed, em função do inescapável componente de política externa contido em operações de empréstimo a países estrangeiros. Esta preocupação era ressaltada pelo fato de que a credibilidade da política de inflação baixa do Fed fundamenta-se sobre este apoio político à sua independência (ibid., p. 12).

A despeito dos limites impostos pelo Congresso, e pelas restrições do uso excessivo do mecanismo por parte de dirigentes do Fed, o ESF chegaria ao início dos anos 80 como um instrumento poderoso de intervenção direta de curto prazo do Tesouro nos mercados internacionais.

\subsection{O FEDERAL RESERVE}

O Sistema da Reserva Federal (o "Fed") foi criado pelo Federal Reserve Act de 1913 para estabilizar o sistema financeiro norte-americano. Até então, os EUA possuíam um dos sistemas financeiros mais frágeis do mundo, caracterizado por crises freqüentes e por violentas flutuações das taxas de juros. A crise de 1907 criou condições políticas para romper a oposição, que vinha desde a fundação dos Estados Unidos, ao estabelecimento de um banco central $^{35}$.

O Federal Reserve Act instituiu o Sistema da Reserva Federal como uma instituição governamental independente, composto por 12 bancos regionais e comandado por um conselho, o Conselho de Governadores do Federal Reserve System. O conselho é composto por sete membros, indicados pelo presidente e confirmados pelo Senado, cujos mandatos são de 14 anos. O longo mandato e a impossibilidade de serem retirados pelo presidente conferem ao conselho certo grau de independência ${ }^{36}$.

As principais funções do Fed são a formulação e execução da política monetária, a regulação e a supervisão das instituições financeiras e a estabilização do sistema financeiro. As decisões relativas à política monetária são tomadas pelo Federal Open Market Committee (FOMC), uma comissão composta pelos membros do Conselho do Federal Reserve e pelos

\footnotetext{
${ }^{35}$ Para uma excelente análise do processo que levou ao Federal Reserve Act de 1913, cf. Broz (1999).
} 
presidentes dos bancos regionais. A atividade de regulação envolve o estabelecimento de regras relativas às operações e atividades das instituições financeiras, bem como à sua composição.

A função do Fed que se relaciona diretamente com o tema deste trabalho é a de estabilização do sistema financeiro. A legislação estabelece diversas formas de intervenção direta do Federal Reserve no sistema financeiro. O Fed tem autoridade para atuar como emprestador de última instância. Para isto, pode fornecer crédito de curto prazo a instituições financeiras por meio da "janela de desconto". A janela de desconto está disponível para os bancos que mantenham reservas em depósito no Fed. Ela é normalmente utilizada por instituições que se vejam com um problema temporário de liquidez. Mesmo que o problema seja mais significativo, o Fed pode utilizar a janela de desconto para ajudar uma instituição em dificuldades a superar o problema. Neste caso, a instituição financeira é monitorada para evitar que a concessão de crédito apenas adie a falência. Em casos de abalo do mercado financeiro como um todo - causado, por exemplo, por desastre natural ou ataque terrorista —, a janela de desconto também pode ser utilizada como instrumento para garantir liquidez às instituições financeiras.

O Art. 3 da Seção 13 do Federal Reserve Act também confere ao Fed o poder de, em circunstâncias excepcionais, conceder crédito em volumes maiores e prazos mais longos para qualquer indivíduo ou empresa que não consiga captar volume equivalente de recursos com emprestadores privados. Este dispositivo foi, por exemplo, a base legal do empréstimo de US\$ 85 bilhões para o salvamento da AIG, em setembro de 2008. Embora o mercado, na ocasião, tenha reagido com alívio à decisão de realizar o empréstimo, as principais lideranças do Legislativo foram rápidas em criticar duramente o uso de recursos públicos para salvar uma instituição privada sem prévia autorização do Congresso ${ }^{37}$.

Como freqüentemente ocorre com as agências federais, o Fed possui uma constituency, a cujas preferências é bastante sensível: os grandes bancos norte-americanos. Há um forte componente de captura burocrática no relacionamento entre o Federal Reserve e os grandes bancos. A quebra de um grande banco seria um elemento de desestabilização do sistema financeiro e, por isso, a política do Fed é impedir a insolvência de qualquer um deles. Isto cria incentivos para que estas instituições assumam riscos excessivamente altos, pois

\footnotetext{
${ }^{36}$ A estrutura do Fed é descrita em detalhes em Board of Governors (2005).

${ }^{37}$ Cf. Federal Reserve (2008) e Andrews (2008).
} 
sabem que, por serem "grandes demais para falir", contam com uma garantia implícita do Fed de que serão resgatados em caso de crise.

\subsubsection{ATUAÇÃO INTERNACIONAL DO FED}

Como banco central do país que emite a moeda de reserva internacional, todas as decisões do Fed têm alguma influência na economia mundial. Um aumento da taxa de juros, por exemplo, valoriza o dólar, o que tende a aumentar as exportações dos outros países aos EUA e reduzir suas importações.

Além dessa intervenção "passiva" no mercado internacional, o Fed também pode intervir de forma ativa nos mercados cambiais. Para isso, ele possui dois instrumentos básicos: a compra direta de moedas estrangeiras, e os acordos de swap estabelecidos com outros bancos centrais.

As operações com moeda estrangeira são reguladas pelo FOMC e realizadas em consonância com o Departamento do Tesouro. O Fed normalmente mantém reservas apenas em euros e ienes, embora esteja autorizado pelo FOMC a operar com as moedas dos outros países industrializados. Adicionalmente, a única moeda de país em desenvolvimento que o Fed está autorizado a comprar é o peso mexicano.

Além de operações diretas de compra e venda de moedas, o Fed possui acordos de swap cambial com vários países. Estes acordos permitem aos participantes obter acesso de curto prazo a moedas estrangeiras por meio de operações de swap. Uma operação de swap é composta por uma transação à vista (spot), na qual o Fed transfere dólares para outro banco central em troca de moeda estrangeira, e por uma transação a prazo (forward), na qual os dois bancos centrais concordam em reverter a transação spot, geralmente em no máximo três meses.

Estes acordos permitem que os bancos centrais estrangeiros obtenham dólares em prazo muito curto, e portanto podem ser importantes em momentos de instabilidade. Por exemplo, logo depois dos atentados de 11 de setembro de 2001, o Banco Central Europeu sacou US\$ 23,5 bilhões de sua linha de swap como garantia contra um eventual ataque especulativo ao euro; como não houve tal ataque, a transação foi revertida depois de três dias.

O estabelecimento, a alteração ou a revogação de um acordo de swap deve ser aprovado pelo FOMC. Até meados dos anos 90, o Fed tinha acordos com mais de dez países. Em 1998, deixou-os expirar, à exceção dos acordos com os bancos centrais do Canadá e do 
México. O acordo com o México, por sinal, foi estabelecido no final dos anos 60 a despeito do receio, no âmbito do próprio FOMC, de que este país poderia se ver, em algum momento, insolvente. Até 2008, o México foi o único país em desenvolvimento com o qual o Fed manteve um acordo de swap. Em 12 de setembro de 2001, foram reestabelecidos acordos de swap com o Banco da Inglaterra e com o Banco Central Europeu. Estes acordos expiraram em 30 dias.

\subsubsection{O BIS}

O Banco de Compensações Internacionais (Bank of International Settlements, ou BIS) é um componente importante da atuação internacional do Federal Reserve. Sediado na Basiléia, na Suíça, serve como fórum de articulação entre os bancos centrais. Trata-se da mais antiga instituição financeira internacional do mundo, e sua história é um exemplo de como burocracias internacionais recusam-se a desaparecer mesmo quando perdem sua sua razão de ser. A instituição foi criada no contexto do Plano Young, de 1930, para assumir a função, até então exercida pelo Agente Geral de Reparações em Berlim, de cobrar e distribuir as reparações da Alemanha. O repúdio de Hitler às reparações tornou a entidade inútil, mas ela em pouco tempo encontrou outra função, especializando-se na cooperação entre os bancos centrais (Delamaide, 1984, p. 146).

Seus primeiros sócios foram os bancos centrais da Alemanha, Bélgica, França, Itália, Japão, e Reino Unido. O Congresso dos EUA não aprovou a entrada do Federal Reserve no BIS, e por isso as ações que caberiam ao Fed foram distribuídas entre os bancos norteamericanos JP Morgan, First National Bank de Nova York e First National Bank de Chicago. Note-se que seus principais sócios eram os bancos centrais dos países industrializados, não seus respectivos governos. Embora, até recentemente, o BIS fosse uma companhia que tinha bancos privados como sócios, sua carta constitutiva conferiu-lhe imunidade de jurisdição similar à gozada por organizações internacionais. Esta imunidade foi confirmada por meio do Protocolo de Bruxelas, assinado pelos governos de 16 países em 1936. Adicionalmente, no acordo de sede assinado em 1987, a Suíça reconheceu o BIS como pessoa de Direito Internacional e garantiu-lhe as imunidades concedidas às outras organizações internacionais sediadas no país.

Na Conferência de Bretton Woods, o BIS tornou-se um motivo de discórdia entre as delegações americana e britânica. Durante a conferência, a delegação da Noruega apresentou 
evidências de que o Banco tinha colaborado com os nazistas e cometido crimes de guerra, e propôs a dissolução do banco. A delegação norte-americana, instruída pelo presidente Franklin Roosevelt, aceitou a proposta dos noruegueses, mas imediatamente encontrou oposição dos britânicos, dos bancos centrais europeus e dos representantes do setor bancário, que conseguiram adiar a decisão final. Por fim, com a morte de Roosevelt, em abril de 1945, as autoridades norte-americanas reverteram sua posição e concordaram em manter o BIS em operação.

Depois da II Guerra, o BIS passou a receber depósitos dos bancos centrais e a servir como a principal câmara de compensação entre eles, tornando-se conhecido como o "banco central dos bancos centrais". O BIS também tornou-se um espaço de coordenação entre os bancos centrais, no qual realizavam discretas reuniões periódicas (Epstein, 1983).

O Fed só se tornou oficialmente membro do BIS em 1994. A despeito disto, representantes do Fed sempre participavam das reuniões organizadas pelo Banco. O presidente do Fed participava das reuniões anuais dos presidentes dos bancos centrais, e um representante do seu Conselho de Governadores tomava parte das reuniões mensais.

Atualmente, o BIS tem 55 bancos centrais como sócios. Ao final de março de 2009, seus ativos eram de aproximadamente US\$ 255,4 bilhões, e seu capital era de US\$ 13,7 bilhões (Bank for International Settlements, 2009). A instituição cobra por suas operações e costuma ser modestamente lucrativa. Em 2009, seu lucro foi de US\$ 446 milhões.

Os estatutos do BIS o proíbem de realizar qualquer operação com prazo superior a 30 dias, ou que não sejam garantidas por um governo ou por ouro depositado no próprio BIS. Por isso, muitas operações negociadas no âmbito do BIS são realizadas, na verdade, pelos próprios bancos centrais. Nestas ocasiões, o Banco participa de fato apenas como consultor técnico e jurídico. Como veremos, este foi o caso do pacote de US\$ 1,85 bilhão negociado com o México em 1982.

\subsection{O FUNDO MONETÁRIO INTERNACIONAL}

Como vimos no capítulo 2, o FMI foi criado em 1944, na Conferência de Bretton Woods. Inicialmente encarregado da prover recursos de curto prazo para países que passassem por desequilíbrios temporários de balança na pagamentos, o FMI perdeu grande parte de sua função com o fim do regime de taxas fixas de câmbio, no início dos anos 70. 
Embora seja uma organização multilateral, as instâncias decisórias, os processos de tomada de decisão e as práticas organizacionais vigentes na instituição permitem que o governo norte-americano exerça grande influência sobre suas políticas. Ao mesmo tempo, estas instâncias e práticas conferem preponderância ao Executivo norte-americano, vis-à-vis o Congresso, no relacionamento com o FMI.

\subsubsection{INSTÂNCIAS DECISÓRIAS}

De acordo com a carta constitutiva do FMI (os Articles of Agreement), a instituição possui três instâncias decisórias: o Conselho de Governadores (Board of Governors), o Comitê Executivo (Executive Board) e o diretor-gerente (Managing Director). Entre 1974 e 1999, o Fundo também possuiu uma instância consultiva, o Comitê Interino (Interim

\section{Committee).}

O Conselho de Governadores é a mais alta instância decisória do Fundo. Cada Estadomembro indica um representante e um suplente para o Conselho; o poder de voto de cada representante é proporcional ao tamanho da quota do Estado que ele representa. Geralmente, os Estados-membros indicam seus ministros da Fazenda ou Tesouro para compor o Conselho, que costuma se reunir uma vez por ano.

A maior parte das decisões é delegada pelo Conselho ao Comitê Executivo. Composto por 24 diretores executivos, o Comitê funciona continuamente, reunindo-se diversas vezes por semana na sede do FMI, em Washington. Cada um dos cinco Estados-membros com as maiores quotas (Estados Unidos, Japão, Alemanha, França e Reino Unido) indica um diretor executivo. Os outros 19 diretores executivos são escolhidos por grupos regionais, que reúnem diversos Estados-membros. A título de exemplo, em 2008, o grupo regional a que pertence o Brasil incluía Colômbia, Equador, Guiana, Haiti, Panamá, República Dominicana, Suriname e Trinidad e Tobago. Como o Brasil possui mais quotas que seus parceiros de grupo regional combinados, cabe apenas ao governo brasileiro a decisão de qual diretor executivo indicar.

O dia-a-dia do FMI está a cargo do diretor-gerente. Indicado pelo Comitê Executivo para um mandato de cinco anos, o diretor-gerente supervisiona o trabalho dos cerca de 3 mil funcionários que compõem o staff da organização. O diretor-gerente também atua como chairman do Comitê Executivo, mas pode votar somente em caso de empate.

O Comitê Interino foi criado em 1974, como um grupo temporário composto por ministros de Finanças ou equivalentes. Cada país ou grupo de países com representação no 
Comitê Executivo indicava um ministro, e as reuniões eram semestrais. O objetivo do Comitê Interino era "aconselhar e reportar-se ao Conselho de Governadores" em questões relacionados ao sistema monetário internacional, assim como propor emendas aos Articles of Agreement. Como instância consultiva, o Comitê Interino não realizava votações formais, decidindo sempre por consenso. Em 1999, foi substituído pelo Comitê Monetário e Financeiro Internacional (Boughton, 2001, pp. 1027-1028).

Uma característica que distingue o FMI de outras organizações internacionais é o fato de que seus Estados-membros não têm o mesmo poder de voto. A quantidade de votos que cada Estado possui é calculada a partir do tamanho da quota de seu Estado: 250 votos "básicos", mais 1 voto adicional para cada DES 100.000,00 de sua quota ${ }^{38}$. A quota, por sua vez, corresponde à contribuição de cada Estado-membro ao capital do Fundo, e é calculada com base no peso relativo do país na economia internacional. Embora a participação dos Estados Unidos no capital total do Fundo tenha se reduzido desde a criação do organismo, o país ainda detém a maior quota (cerca de $17,1 \%$ do total em julho de 2008). Em virtude disso, detém também a maior quantidade de votos $(16,8 \%$ do total), seguido por Japão $(6,0 \%$ dos votos), Alemanha (5,9\%), França $(4,9 \%)$ e Reino Unido $(4,9 \%)^{39}$.

A diferença entre os poderes de voto dos Estados-membros aplica-se tanto ao Conselho de Governadores quanto ao Comitê Executivo. Por exemplo, neste último órgão, os cinco diretores executivos com maior poder de voto detêm cerca de 38,5\% dos votos. Ademais, os diretores executivos não podem separar seus votos; devem usar todos os votos que possuírem para apoiar uma única alternativa de ação. Caso os países que componham um grupo regional não tenham a mesma posição com relação a uma questão em pauta, a decisão sobre qual posição apoiar cabe inteiramente ao seu respectivo diretor executivo.

A divisão dos Estados-membros entre os grupos não é regulada por nenhum dispositivo formal, mas mesmo assim os grupos têm se mantido relativamente estáveis ao longo do tempo (Leech, 2002, pp. 380-381). Ao se compor os grupos, procura-se evitar que algum deles agregue número de votos tal que torne seu diretor executivo mais poderoso do que qualquer um dos diretores que representam os cinco países com maiores quotas (Leech e

\footnotetext{
${ }^{38}$ A alocação de 250 votos básicos visava a oferecer um poder de voto mínimo a cada Estado-membro. No entanto, a despeito de sucessivos aumentos do capital do Fundo - que se refletiu em aumentos na quantidade de votos variáveis - o número de votos básicos alocados a cada membro nunca foi alterada. Por isso, a proporção dos votos básicos na quantidade total de votos tornou-se insignificante, baixando de $14 \%$ em 1956 para $2 \%$ em julho de 2008 (cf. Leech 2002, p. 382).

${ }^{39}$ Cf. IMF, “IMF Members' Quotas and Voting Power, and IMF Board of Governors". Disponível em $<$ http://www.imf.org/external/np/sec/memdir/members.htm>. Acesso em 3/07/2008.
} 
Leech, 2005, p. 9) ${ }^{40}$. Este critério faz com que os grupos regionais geralmente combinem países com quantidades de votos bastante diferentes, reduzindo ainda mais o poder dos países com menor peso. Por exemplo, o Canadá possui 79,3\% dos votos do seu grupo regional (que inclui a Irlanda e diversos países da América Central e do Caribe), a Suíça controla 56,3\% dos votos do seu grupo (que inclui Polônia, Sérvia e Uzbequistão, entre outros), a Itália tem $77,8 \%$ dos votos do seu grupo (que inclui Albânia, Grécia, Portugal e Timor Leste), o Brasil conta com 57,1\% dos votos do seu grupo (que inclui Colômbia, Equador e outros países das Américas Central e do Sul) e a Índia detém $80,3 \%$ dos votos de um grupo que também conta com Bangladesh, Butão e Sri Lanka. Por disporem da maioria dos votos de seus respectivos grupos, cada um destes cinco países pode escolher unilateralmente um diretor executivo, com efeito aumentando seu poder de voto no Comitê Executivo à custa dos outros membros de seus grupos ${ }^{41}$. Desta forma, a Itália amplia seu poder de voto de 3,20\% para 4,11\%, o Canadá amplia o seu de 2,89\% para 3,64\%, a Suíça o aumenta de 1,57\% para 2,79\%, o Brasil, de $1,38 \%$ para $2,42 \%$ e a Índia, de $1,89 \%$ para $2,35 \%{ }^{42}$.

Como o critério de agrupamento em grupos regionais reduz o poder de voto dos pequenos Estados, a composição do Comitê Executivo tende a garantir que o bloco formado por EUA, Europa Ocidental e Japão seja dominante. Por exemplo, em julho de 2008 os diretores executivos dos EUA, Japão, Alemanha, França, Reino Unido, Bélgica, Holanda, Itália e Suíça controlavam 55,21\% do poder de voto do Comitê, embora seus países somassem apenas $47,61 \%$ do total de votos.

Embora o Conselho de Governadores seja hierarquicamente superior ao Comitê Executivo, este último órgão é que detém, na prática, o poder sobre a organização. As reuniões do Conselho de Governadores quase sempre são apenas cerimoniais. Como os representantes de cada Estado-membro no Conselho e no Comitê são escolhidos pelos mesmos indivíduos (as autoridades monetárias do Estado em questão), as posições de ambos os representantes são bastante alinhadas. A delegação de autoridade do Conselho de Governadores ao Comitê Executivo serve para acelerar o processo de tomada de decisões, pois o número de integrantes deste último é bem menor do que o do primeiro. Como tem

\footnotetext{
${ }^{40}$ De fato, apenas o diretor executivo que representa o grupo que inclui Áustria, Bélgica e Hungria controla mais votos (5,14\% do total) do que os diretores executivos da França e do Reino Unido (4,86\% cada um).

${ }^{41}$ Leech e Leech (2005, p. 21) apontam para o fato que Bélgica, Holanda, Austrália e Argentina, embora não possuam a maioria absoluta dos votos de seus grupos regionais, sempre elegem seus respectivos diretores executivos. Estes países também obtêm um aumento em seu poder de voto, em detrimento de seus colegas de grupo.

${ }^{42}$ Com base na distribuição de quotas vigente em julho de 2008 .
} 
autoridade e capacidade para tomar decisões, o Comitê Executivo é o verdadeiro locus do poder no Fundo.

A autoridade do Comitê Executivo é reforçada por três outros instrumentos. O primeiro é a possibilidade de demitir o diretor-gerente a qualquer tempo. O segundo é a autoridade para autorizar despesas, tanto ordinárias quanto extraordinárias, sujeita apenas à revisão anual por parte do Conselho de Governadores. O terceiro, finalmente, é a provisão que permite ao Comitê decidir sobre questões de interpretação, inclusive sobre os limites de sua própria autoridade (Hexner, 1964, p. 78).

Além de serem os detentores da maior quota individual e, portanto, do maior poder de voto dentre todos os Estados-membros, os EUA possuem outros privilégios que lhe garantem, na prática, o controle sobre o Fundo.

O primeiro é o requisito de que algumas decisões-chave sejam aprovadas com maioria de $85 \%$ dos votos. Tal quantidade de votos é necessária para, entre outras, (i) realizar qualquer mudança na alocação ou quantidade de quotas, (ii) alterar os prazos de pagamento dos empréstimos do Fundo ${ }^{43}$, (iii) realizar certas operações de empréstimo, (iv) alterar o número de diretores executivos eleitos por grupos regionais, (v) alocar ou cancelar Direitos Especiais de Saque, (vi) declarar um Estado-membro inelegível a usar os recursos do Fundo, cassar seu poder de voto ou excluí-lo em definitivo da organização, e (vii) emendar os Articles of Agreement, além de outras decisões relativas a operações com ouro, moedas, gerenciamento de taxas de câmbio e interpretação de regras, para um total de 18 assuntos que exigem tal maioria. Outras 21 decisões exigem $70 \%$ dos votos para serem aprovadas, e portanto podem ser vetadas pelo conjunto dos cinco Estados-membros com mais poder de voto (Buira, 1995, pp. 30-31). Segundo Buira, "a exigência de maiorias especiais freqüentemente tem o efeito de inibir até mesmo a discussão de assuntos importantes que seriam difíceis de resolver", já que os participantes podem antecipar que os EUA usarão seu poder de veto, se necessário, para impedir que certas medidas sejam aprovadas.

\subsubsection{PROCESSO DECISÓRIO}

Como em toda Organização Internacional, o processo decisório do Comitê Executivo do FMI é regulado por regras não-escritas. Embora qualquer diretor executivo possa incluir um tema na pauta de uma reunião do Comitê, na prática a pauta é definida pelo diretor- 
gerente, após consultar informalmente com os diretores executivos com maiores interesses na questão e obter, do staff do Fundo, um relatório técnico. Membros do staff são chamados a participar das reuniões quando um assunto no qual são especialistas está na pauta. Todo o material preparatório, assim como o conteúdo das reuniões, é confidencial, cabendo aos diretores executivos informar aos Estados-membros que representam as deliberações do Comitê. Posturas confrontacionais ou argumentativas são mal recebidas entre os membros do Comitê; assim, um diretor executivo será mais efetivo se for capaz de enquadrar os interesses do seu Estado no contexto mais amplo das obrigações do Fundo, e de manter boas relações com os outros diretores executivos (Hexner, 1964, p. 80-81).

No Comitê Executivo, dá-se preferência à construção de consenso, e poucas decisões chegam a ser votadas. Segundo o próprio Regimento Interno do FMI, o diretor-gerente deve normalmente usar o "sentimento da reunião" ("sense of the meeting") como substituto de uma votação formal (International Monetary Fund, 2009, regra C-10). O “sentimento da reunião" é a posição que obteria a maioria dos votos caso a questão fosse levada a votação (Van Houtven 2002, p. 23), e esta regra foi incluída no Regimento Interno do FMI por insistência dos EUA e do Reino Unido, pois os norte-americanos queriam "obscurecer a voz do poder dos EUA, que mesmo assim era decisiva" (Thacker, 1999, p. 42). Embora os diretores executivos tenham a prerrogativa de requisitar uma votação (segundo o Art. XII dos Articles of Agreement), isto raramente é feito. Segundo Karin Lissakers, durante seu mandato como diretora executiva dos EUA no Fundo (entre 1993 e 2001), o Comitê Executivo tomou mais de duas mil decisões, mas houve votação em apenas cerca de uma dúzia delas (Schaefer, 2001).

Como os EUA detêm poder de veto sobre muitas decisões, em geral basta que seu diretor executivo indique sua discordância sobre um item da pauta para que ele nem chegue a ser votado. A influência dos EUA na organização fica protegida de votações que poderiam opor o país abertamente aos outros Estados-membros. Ademais, como afirma Thacker (1999, pp. 40-41), o poder de veto dos EUA permite-lhe estender sua influência para questões que não requerem maioria de $85 \%$, pois os outros Estados-membros relutarão antes de se opor a uma decisão apoiada pelos EUA, com medo de sofrerem retaliação numa outra questão que requeira os $85 \%$ de votos. Segundo afirmou um diretor executivo entrevistado por Momani (2004), "os diretores executivos não eram tratados como iguais dentro da instituição", pois "os Estados Unidos tinham a presença mais forte no Comitê Executivo", o "diretor executivo

\footnotetext{
${ }^{43}$ Na linguagem do FMI, fala-se em "recompra" da moeda do país, já que, tecnicamente, o Fundo "vende"
} 
dos EUA recebia documentos e marcava reuniões com membros do staff mais rapidamente do que os outros diretores", e o diretor-gerente "freqüentemente regurgitava as posições dos Estados Unidos em suas declarações” (p. 896).

O próprio processo de escolha do diretor-gerente reforça a influência dos EUA na organização. Os Articles of Agreement determinam apenas que "o Comitê Executivo deverá selecionar um diretor-gerente que não seja nem um governador nem um diretor executivo" (Art. XII, Seção 4). Esta decisão requer apenas maioria absoluta dos votos do Comitê Executivo. No entanto, desde a criação das instituições de Bretton Woods tem prevalecido a convenção que determina que o presidente do Banco Mundial deve ser um cidadão norteamericano, ao passo que o diretor-gerente do FMI deve ser um europeu. Nunca houve uma votação do Comitê Executivo para selecionar um diretor-gerente. Os países europeus selecionam um candidato e um de seus diretores executivos apresenta formalmente o nome para o Comitê Executivo. O nome é testado informalmente numa reunião fechada (Kahler, 2001, pp. 23-25). Geralmente, a anuência dos EUA e do Japão ao nome proposto é suficiente para que o diretor-gerente em exercício, adotando a regra do "sentimento da reunião", apenas referende o nome indicado pelos europeus, sem necessidade de se levar a questão a voto formal. Desta forma, os EUA detêm, na prática, poder de veto sobre a seleção do diretorgerente, como ficou demonstrado na escolha do sucessor de Michel Camdessus, em $2000^{44}$.

Finalmente, Leech e Leech (2005) mostram que a própria estrutura de votação, na qual cada diretor executivo possui quantidades diferentes de votos, aumenta a influência dos Estados Unidos no Comitê Executivo. Sua análise parte da percepção de que o poder de um membro de um colegiado pode ser definido como sua capacidade de, ao unir-se a uma coalizão, torná-la majoritária e, analogamente, sua capacidade de, ao deixar uma coalizão, privá-la dos votos necessários para aprovar uma medida. Neste caso, a proporção de votos de cada membro é apenas um input, que não se confunde com seu poder efetivo, que é a sua capacidade de determinar resultados.

Um exemplo é útil para demonstrar a diferença entre proporção de votos e poder efetivo. Suponha-se um colegiado com quatro membros, no qual o membro A possua 10 votos, B possua 8 , C possua 5 e D possua 1 voto. Uma decisão, para ser aprovada, precisa de

moedas conversíveis em troca de quantidade equivalente em moeda local.

${ }^{44}$ Nesta ocasião, o bloco europeu indicou Caio Koch-Weser, vice-ministro de Finanças da Alemanha. Assim que sua candidatura foi apresentada por um dos diretores executivos da Europa, os EUA anunciaram o veto a seu nome. Um mês depois, o nome de Koch-Weser foi retirado e substituído por Horst Köhler, que foi eleito (Kahn, 2000a, 2000b). 
13 votos (50\% mais um dos 24 votos totais). Nesta situação, D não detém nenhum poder efetivo, pois ele não é decisivo para a formação de nenhuma coalizão vencedora $(A+B, A+C$ ou $\mathrm{B}+\mathrm{C}$ são suficientes para obter os 13 votos, e $\mathrm{A}+\mathrm{D}, \mathrm{B}+\mathrm{D}$ e $\mathrm{C}+\mathrm{D}$ não são). Da mesma forma, embora tenham quantidades de votos bastante diferentes, o poder efetivo de A, B e C é idêntico, pois ambos dependem de um dos outros dois membros para formar uma coalizão vencedora. Suponha-se, agora, que um novo membro E entre no colegiado, recebendo um voto que é retirado de B. Esta pequena alteração muda o poder efetivo dos membros: $\mathrm{B}$ e $\mathrm{C}$ perdem poder vis-à-vis o membro A, pois uma coalizão entre os dois não é mais suficiente para vencê-lo; D ganha poder, pois pode ser decisivo numa coalizão com B e C; e A também ganha poder, pois continua a depender apenas de uma aliança com B ou C para aprovar uma medida, e passa a poder bloquear qualquer iniciativa destes dois membros com uma coalizão com D e E.

A partir desta definição de poder como capacidade de influenciar resultados, Leech e Leech calculam um "índice de poder" de cada membro de um colegiado como a proporção entre as coalizões vencedoras nas quais este membro é decisivo (ou seja, nas quais sua saída implica na derrota da coalizão) e o número total de coalizões (incluindo aquelas das quais o membro não faz parte). A partir dos "índices de poder" de todos os membros do colegiado, calcula-se a "parcela de poder" de cada um, que corresponde à sua capacidade de influenciar resultados comparativamente à capacidade dos outros membros ${ }^{45}$.

Usando a distribuição de votos vigente em 2005, Leech e Leech calculam que os EUA possuíam à época uma parcela de poder de 21,5\% no Comitê Executivo, embora dispusessem de apenas $17,1 \%$ dos votos. Este aumento do poder efetivo com relação ao poder de voto é obtido às custas de todos os outros membros do Comitê. Além de possuir mais quotas e mais votos, e de deter poder de veto sobre várias decisões, os EUA são favorecidos por um viés criado pelo próprio sistema de votação adotado no Comitê Executivo, que lhe confere mais poder do que sua parcela de votos faz parecer.

\subsubsection{Práticas ORganizaCionais}

Finalmente, uma forma sutil de influência dos EUA sobre o FMI advém da própria localização geográfica da organização. O fato de o Fundo estar sediado em Washington oferece ao governo norte-americano uma posição privilegiada para influenciar suas decisões e

\footnotetext{
${ }^{45}$ Para uma discussão detalhada desta metodologia, cf. Leech (2002).
} 
controlar suas ações ${ }^{46}$. A sede do FMI fica a poucas quadras do Departamento do Tesouro, do Federal Reserve e do Congresso. Esta proximidade permite que funcionários do governo norte-americano mantenham freqüentes contatos pessoais com o staff do Fundo. Estes contatos são uma forma particularmente importante de influência porque, como vimos, o processo decisório privilegia mecanismos informais de coordenação. $\mathrm{O}$ acesso dos outros Estados-membros aos altos funcionários do FMI é mais restrito; embora os diretores executivos morem em Washington, as equipes à sua disposição são minúsculas se comparadas às equipes do Tesouro e do Fed. Se uma autoridade estrangeira — um chefe de Estado, ministro da Fazenda ou presidente de banco central - precisar conversar pessoalmente com o Diretor Gerente, terá de empreender uma viagem até Washington que terá de ser planejada com certa antecedência e lhe custará entre dois a quatro dias de uma agenda já muito carregada. As autoridades norte-americanas, por seu turno, podem marcar uma reunião com o Diretor Executivo em questão de horas, e conversar com ele pessoalmente sem precisar se deslocar de sua cidade.

Outra vantagem que a localização do FMI oferece aos EUA é a influência de atores não-governamentais sobre a entidade. A proximidade física do FMI com relação às universidades da Costa Leste torna estas instituições particularmente bem posicionadas para influenciar as decisões do Fundo. Um economista de Princeton ou do MIT pode deslocar-se até a sede do FMI, proferir uma palestra ou participar de uma reunião e voltar para sua cidade de origem em questão de algumas horas. Um pesquisador da América Latina precisará de pelo menos dois dias, e um da Ásia precisará do dobro disso.

A localização também tem impacto direto sobre a nacionalidade da equipe que compõe a organização. Nacionais norte-americanos têm mais facilidade para obter emprego no Fundo; de fato, em 1980, 25,9\% dos seus funcionários eram norte-americanos, e em 2002 este número era de 24,4\% (Hamlet e Kapur, 2004, p. 24). A grande proporção de cidadãos norte-americanos representa uma forma de soft power dos EUA na organização.

Na mesma linha, outra forma de influência indireta dos EUA sobre o FMI advém do processo de recrutamento e seleção de pessoal. Como mostra Momani (2005), quase todos os economistas contratados pelo Fundo são formados nos EUA ou na Inglaterra. Ademais, uma parcela desproporcional dos economistas que trabalham no FMI são norte-americanos, europeus e canadenses. Um estudo realizado em 1968 mostrou que 23 dos 54 ocupantes de

\footnotetext{
${ }^{46}$ O conteúdo desta seção é baseado em Hamlet e Kapur (2004).
} 
cargos de chefia eram nacionais norte-americanos, seis eram britânicos, quatro eram franceses, quatro eram holandeses, dois eram canadenses e um era australiano, enquanto apenas sete eram cidadãos de países asiáticos e dois de países latinoamericanos (Strange, 1974, p. 269). Trinta anos depois, a quantidade de membros do staff oriundos de países industrializados anglo-saxões ainda era desproporcionalmente alta: $41 \%$ do total (Woods, 2002, pp. 108-109).

Os critérios mínimos para que um candidato seja considerado no processo de seleção são (i) idade máxima de 33 anos, (ii) pós-graduação em Economia ou disciplina correlata, (iii) uma trajetória acadêmica de destaque, (iv) comunicar-se bem em inglês, (v) possuir habilidades quantitativas, e (vi) demonstrar interesse e aptidão para trabalhar numa organização internacional (Momani, 2005, p. 172). O processo de seleção é fortemente enviesado em favor de candidatos que tenham estudado nas escolas de Economia "certas", ou seja, as que produzem os "melhores economistas" - evidentemente, escolas que oferecem treinamento avançado em Economia neoclássica. Segundo Momani,

A administração e o pessoal sênior do FMI tinham noções preconcebidas sobre quais universidades produziam os "melhores economistas". No final dos anos 90, de fato, a Divisão de Recrutamento do Fundo categorizou as universidades selecionadas como parte de um grupo percebido como as "Vinte Melhores". As Vinte Melhores eram todas universidades norte-americanas, e muitas estavam na "Ivy League", como MIT, Harvard, Princeton, Columbia, Yale e Stanford. (2005, p. 179).

Em 1997, dos 31 economistas contratados pelo processo de admissão do FMI, 16 obtiveram seu grau acadêmico mais alto numa universidade norte-americana (dez deles numa das "Vinte Melhores"), cinco numa universidade britânica, nove em outra universidade na Europa e um no Japão (Momani, 2005, apêndice 2). Outro dado que comprova a hegemonia das universidades norte-americanas e européias é o fato de que, entre 1980 e 1983, foram contratados 29 economistas de países em desenvolvimento, mas apenas um desses completou seus estudos em seu país de origem, ao passo que 20 o fizeram nos EUA, sete no Reino Unido ou na França, e um no Canadá (ibidem, p. 180).

Como resultado, o quadro de pessoal do Fundo tem uma formação homogênea, que não questiona as políticas econômicas propostas pela organização. De fato, idéias como política industrial, abordagens de apoio a indústrias nascentes ou industrialização por substituição de importações são desacreditadas pelo staff do Fundo. A homogeneização, que começa no recrutamento, é reforçada pelo treinamento e pela socialização; como afirmou um membro do staff, "seu sucesso no Fundo é determinado por sua habilidade de se adaptar ao 
Fundo" (Momani, 2005, p. 181). O próprio Michel Camdessus, quando Diretor Gerente, afirmou que "a disciplina intelectual será mantida enquanto eu estiver aqui — nós lidamos com crises e não podemos ter nossas tropas repensando a estratégia no campo de batalha" (ibidem, p. 182). Finalmente, as pesquisas realizadas pelo Fundo também são verificadas pelo Departamento de Desenvolvimento e Verificação de Políticas - chamado de "polícia de pensamento" por um membro do staff —, cuja função é garantir que as propostas produzidas pelo Fundo se enquadrem no paradigma econômico neoclássico. Este paradigma reflete a tradicional posição do governo norte-americano, que desencoraja que os países em desenvolvimento adotem abordagens "estatistas" ou "desenvolvimentistas", incentivando-os a dar preferência a políticas econômicas de caráter liberal.

O fato de que as instituições formais do FMI, suas regras de recrutamento e seleção de pessoal e sua própria localização aumentam a influência norte-americana sobre o órgão não significa que os EUA detenham controle total sobre ele. No entanto, seria difícil negar que os EUA desfrutam de uma posição especial com relação ao Fundo. Até o início dos anos 70, nenhum saque era concedido pelo FMI sem a anuência dos EUA (Woods, 2002, p. 92 e 103). Considerações estratégicas dos Estados Unidos geralmente eram tão relevantes para a decisão de conceder ou não um empréstimo a um Estado-membro quanto o tamanho da economia deste Estado ou sua capacidade de pagamento (Woods, 2002, p. 103). Diversos estudos quantitativos recentes têm apontado que as decisões do FMI são influenciadas por interesses dos EUA e, portanto, não seguem critérios estritamente técnicos ${ }^{47}$.

\subsection{O RELACIONAMENTO ENTRE O CONGRESSO E O FMI}

A influência do Executivo sobre o FMI é muito maior do que a do Congresso. Em particular, o Departamento do Tesouro é o órgão norte-americano com maior peso na administração do Fundo. Esta assimetria entre a influência do Executivo e do Congresso sobre o organismo deve-se à estrutura institucional norte-americana, que confere ao Executivo a primazia sobre assuntos de política externa.

O FMI interage de fato com os Estados-membros por meio dos seus representantes; estes são escolhidos pelos seus respectivos ministérios da Fazenda e bancos centrais. Nos EUA, o Presidente tem autoridade final sobre a política do país com relação ao Fundo. Esta autoridade é delegada ao Departamento do Tesouro, que é o ponto focal de contatos com o

\footnotetext{
${ }^{47}$ Cf. Dreher e Jensen (2005), Oatley e Yackee (2004) e Thacker (1999).
} 
FMI. No Tesouro, o Subsecretário para Assuntos Internacionais é o responsável por gerir o dia-a-dia da participação dos EUA na instituição. O Fundo também está freqüentemente em contato com o Federal Reserve, em virtude de sua importância como regulador do sistema bancário norte-americano e de sua proximidade geográfica com a sede do FMI.

O Congresso não tem canais oficiais de interlocução com o Fundo. Por ser uma organização internacional, o FMI goza de imunidade de jurisdição e, portanto, não se submete ao sistema legal norte-americano. Ele não precisa prestar contas ao Congresso, que não tem o direito de requisitar-lhe diretamente informações de qualquer tipo, nem de convocar qualquer funcionário da organização. Também não tem o direito de obrigar seu staff a atuar de determinada maneira. Para obter informações que não sejam disponíveis ao público, o Congresso precisa requisitá-las aos representantes dos EUA no Conselho de Governadores ou ao Comitê Executivo. Para influenciar decisões do FMI, o Congresso pode no máximo instruir o diretor executivo dos EUA a votar de determinada forma - algo que, num ambiente institucional em que raramente alguma coisa é votada, tem pouca utilidade.

O diretor executivo dos EUA é indicado pelo Presidente e deve ser confirmado pelo Senado. Uma vez aprovado pelo Senado, o diretor executivo não se reporta mais ao Congresso, apenas ao secretário do Tesouro. Para tentar influenciar as decisões do diretor executivo, o Congresso em diversas oportunidades aprovou leis de "voz e voto", que obrigam o secretário do Tesouro a instruir o diretor executivo dos EUA no Fundo a assumir determinadas posições nas votações do Comitê Executivo (Wertman e Hairston, 1998). Por exemplo, a Lei Anti-Terrorrista de 1996 obrigava o secretário do Tesouro a instruir o diretor executivo norte-americano a se opor a qualquer empréstimo ou outro uso de recursos das instituições financeiras internacionais em favor de países que o Departamento de Estado considerasse oficialmente patrocinadores do terrorismo. No entanto, além de ter poucos efeitos práticos em virtude da ausência de punições em caso de não-cumprimento, este tipo de legislação não reduz a preponderância do Executivo no relacionamento dos EUA com o Fundo (Johnson e Schaefer, 1998). O máximo que o Congresso consegue chegar no sentido de aumentar a supervisão direta sobre a política do país para o FMI é publicar sugestões de políticas por meio de resoluções que refletem o "sentimento do Congresso" ou em relatórios de Comissões (Sanford, Weiss, 2004, p. 3). 
A despeito da posição preeminente do Executivo no relacionamento com o FMI, existe uma situação na qual o Congresso consegue obter influência sobre o Executivo: nos aumentos do capital do Fundo.

O capital do FMI é composto por contribuições (quotas) dos Estados-membros. Este capital é expandido periodicamente, para atender ao aumento das necessidades de financiamento e ao alargamento da atuação da organização. Uma revisão geral das quotas do FMI é conduzida pelo Conselho de Governadores a intervalos regulares (de aproximadamente cinco anos). Caso haja necessidade, é possível proceder-se a uma revisão fora do prazo previsto. Até hoje, 14 revisões já foram efetuadas, das quais dez resultaram em aumento no capital do Fundo (60,7\% em 1958, 30,7\% em 1965, 35,4\% em 1970, 33,6\% em 1976, 50,9\% em 1978, 47,5\% em 1983, 50,0\% em 1990 e 45\% em 1998) ${ }^{48}$.

Uma revisão das quotas deve ser aprovada por $85 \%$ dos votos dos Estados-membros. Como os EUA detêm mais de $15 \%$ dos votos totais, nenhuma revisão pode ser aprovada sem o consentimento do país. Qualquer revisão que implique em aumento da contribuição dos EUA deve ser autorizada pelo Congresso, a despeito de tecnicamente ser considerada uma "troca de ativos", na qual o governo norte-americano entrega dólares em troca de DES ${ }^{49}$. Desde 1980, as revisões de quotas são consideradas parte do processo orçamentário e requerem autorização e apropriação por parte das duas câmaras do Congresso, embora não representem aumento das despesas públicas (Wertman, 1998, pp. 13-14). Desta maneira, o Congresso poderia aprovar um aumento na quota dos EUA menor do que requisitada pelo Executivo, mas isso equivaleria a uma rejeição de toda a revisão, já que os Articles of Agreement exigem a aprovação de $85 \%$ dos Estados-membros para que ela seja efetuada, e não abre a possibilidade de aprovação com emendas. Na prática, portanto, o processo de revisão das quotas do FMI é similar a um jogo de dois níveis de Putnam (1988), no qual o Executivo inicialmente negocia uma proposta com o Fundo e com os outros Estadosmembros, e depois precisa obter a aprovação do Legislativo.

A necessidade de aprovação do Congresso para aumentos nas quotas cria possibilidades de influência do Legislativo na gestão do FMI. Em primeiro lugar, o Congresso

\footnotetext{
${ }^{48}$ Duas revisões realizadas depois de 1998 apenas mudaram a distribuição das quotas, mas não o capital total do Fundo.Em abril de 2008, um grande aumento do capital do FMI foi aprovado pelo Conselho de Governadores. Até março de 2010, o aumento não entrou em vigor porque a medida ainda não obtivera a aceitação de Estadosmembros representando pelo menos 85\% dos votos. Cf. "IMF Quotas", disponível em http://www.imf.org/external/np/exr/facts/quotas.htm. Acesso em 3 de abril de 2010.

49 A autorização do Congresso foi estabelecida pela Seção 5 da Lei dos Acordos de Bretton Woods de 1945 (P.L. 79-181; 22USC 286). Cf. Wertman (1998, p. 3).
} 
pode estabelecer um "teto" ao montante das quotas dos EUA no organismo. Como a aprovação dos EUA é imprescindível para que um aumento de capital entre em vigor, o Congresso americano pode, na prática, limitar o total do capital disponível ao FMI. E este capital é o instrumento que o Fundo possui para intervir no sistema financeiro internacional; quanto maior ele for, maior será seu poder de intervenção. Disto decorre que o Congresso pode limitar, ainda que indiretamente, a influência do FMI na economia internacional, negando-se a autorizar aumentos na contribuição norte-americana que estejam acima de determinado patamar.

Uma segunda forma de influência do Congresso é condicionar a aprovação de aumentos nas quotas à aprovação de outras leis de seu interesse. Como veremos, em 1983 o Congresso condicionou o aumento no capital do Fundo, desde o início, à aprovação de uma legislação de regulação bancária mais restritiva, e a medida só foi aprovada depois que o governo aceitou incluir uma lei de habitação no projeto. Note-se que, nesta situação, o Congresso troca um aumento na capacidade de intervenção internacional direta do Fundo (e, portanto, também do Tesouro) por reformas legislativas no plano doméstico.

É importante notar que o Congresso não tem nenhum poder de influenciar decisões individuais de empréstimo. O Congresso, por meio da legislação de "voz e voto", pode aprovar diretivas que estabeleçam princípios gerais da atuação do diretor executivo dos EUA no Fundo. Também pode negar-se a autorizar aumentos no capital do Fundo que julgue excessivos. Mas seus poderes não são suficientes para permitir-lhe interferir diretamente em quaisquer operações. O dia-a-dia do Fundo está a cargo do diretor-gerente e do Comitê Executivo, e o relacionamento dos EUA com essas instâncias decisórias é monopolizado pelo Departamento do Tesouro. 


\section{A crise da dívida}

Na manhã de 12 de agosto de 1982, o ministro da Fazenda do México, Jesus Silva Herzog, fez três telefonemas para Washington. Ligou, em primeiro lugar, para o Secretário do Tesouro dos Estados Unidos, Donald Regan. A seguir, telefonou para o presidente do Federal Reserve, Paul Volcker. Por fim, ligou para o diretor-gerente do FMI, Jacques de Larosière. Aos três, transmitiu a mesma mensagem: as reservas externas do México estavam virtualmente esgotadas e, se não recebesse ajuda do governo dos EUA ou do FMI, o país não poderia realizar os pagamentos agendados para a segunda-feira seguinte, 16 de agosto.

Os três telefonemas marcam o início do processo que se convencionou denominar de “crise da dívida dos anos 80". Iniciada pelo México em agosto, a crise já atingiria quase todos os países da América Latina em dezembro. Mas a crise não era apenas dos países devedores. Era, principalmente, uma crise do sistema financeiro internacional e, em especial, do sistema financeiro dos Estados Unidos. O anúncio de Silva Herzog encerrava um período de quase dez anos de crédito fácil e barato para os países subdesenvolvidos, nos quais estes acumularam dívidas imensas e ao mesmo tempo se tornaram os melhores clientes dos bancos norte-americanos. Por isso, o esgotamento das reservas mexicanas trazia o risco de uma catástrofe financeira. Naquele momento, o total de empréstimos concedidos (exposição) por bancos norte-americanos aos países da América Latina correspondia a 119\% do capital destes bancos. A posição dos nove maiores bancos era ainda mais vulnerável: sua exposição aos países da América Latina era de 176\% de seu capital. Como, pela legislação norte-americana, um banco era considerado insolvente e poderia ser liquidado pelo Fed quando suas perdas em empréstimos igualassem seu capital, os principais bancos dos Estados Unidos corriam risco de falência se os devedores se recusassem a pagar mais do que $40 \%$ do valor de face de seus empréstimos. Mesmo reduções menores que $60 \%$ no valor de face dos empréstimos causariam grandes reduções no capital dos principais bancos, reduzindo bruscamente sua capacidade de conceder novos empréstimos e, desta forma, ocasionando um aperto de crédito que teria profundos efeitos negativos sobre toda a economia.

Neste capítulo, procurarei mostrar que a estratégia de gerenciamento da crise desencadeada pelo anúncio do México foi montada e comandada pelo governo dos Estados Unidos, particularmente pelo Departamento do Tesouro e pelo Federal Reserve. O capítulo 
também defenderá que a delegação da gestão da crise ao FMI favoreceu determinada forma de encaminhamento do problema, em detrimento de outras alternativas, ao mesmo tempo em que reduziu a ingerência do Congresso norte-americano na questão.

\subsection{ANTECEDENTES E CONTEXTO POLÍTICO DA CRISE DA DÍVIDA}

A crise financeira que atingiria os países em desenvolvimento da América Latina e da Europa Oriental nos anos 80 foi o resultado de uma bolha de crédito a tomadores soberanos que começou no início dos anos 70.

Esta bolha começou com um choque de oferta de petróleo. Em outubro de 1973, os países árabes produtores de petróleo responderam à Guerra do Yom Kippur com um corte na produção e o embargo no envio do produto para os EUA e os Países Baixos. Como resultado, o preço do óleo cru subiu de US\$ 3,00 o barril em outubro para US\$ 11,65 em janeiro de $1974^{50}$

Este súbito aumento de $300 \%$ no preço do petróleo alterou os padrões de comércio e finanças internacionais. Subitamente, os países produtores de petróleo passavam a obter expressivos superávits, com os quais acumulavam reservas, enquanto os consumidores do produto amargavam déficits sucessivos, que precisavam ser financiados. No decorrer de 1974, surgiram propostas de utilizar o FMI e o Banco Mundial para financiar os déficits dos países consumidores de petróleo com os superávits dos países produtores, num esquema similar ao de uma câmara de compensação. No entanto, na reunião anual do Fundo e do Banco em setembro, as autoridades monetárias dos países industrializados — em particular dos EUA decidiram que seria melhor deixar esta tarefa para o setor privado. Segundo Denis Healey, então chanceler do Exchequer do Reino Unido,

Eu tentei muito [...] convencer meus colegas a organizar alguma forma de esquema oficial internacional para reciclar os superávits da OPEP. Mas os americanos, particularmente, foram muito hostis à idéia. Basicamente, eles não acreditavam em o governo se meter no que eles pensavam que deveria ser o papel do setor privado. Eles preferiam deixar tudo para os banqueiros, que estavam lambendo os beiços só de pensar no que eles iam lucrar (apud Lissakers, 1991, p. 29).

O fato de que os países superavitários eram grandes produtores de petróleo teve um efeito importante na estrutura que o mercado de "reciclagem de dólares" assumiria. Os

\footnotetext{
${ }^{50}$ O processo que tornou possível o choque de 1973 já estava em curso há bastante tempo. À medida que aumentou a participação do Oriente Médio na oferta mundial do petróleo, as "Sete Irmãs" perderam gradativamente seu poder de determinar o preço do produto, que passou para os países produtores. Um marco deste processo foi a criação da OPEP, no início dos anos 70. Em 1976, os países da OPEP respondiam por 65\% da produção mundial (Lissakers, 1991, pp. 30-31).
} 
superávits gerados pelo petróleo concentraram-se em poucas mãos. Apenas três países Arábia Saudita, Kuwait e Emirados Árabes Unidos — foram responsáveis por mais de 80\% da acumulação de ativos estrangeiros dos membros da OPEP. Dentro destes países, um conjunto reduzido de pessoas tinha autoridade sobre os fundos obtidos com as receitas do petróleo. Na Arábia Saudita, a Autoridade Monetária da Arábia Saudita (SAMA) controlava 84\% dos ativos externos do país em 1983, enquanto, no Kuwait, a família Sabah controlava $75 \%$ dos ativos externos. Esta concentração do controle dos recursos facilitou aos grandes bancos norte-americanos, historicamente associados aos interesses da indústria do petróleo, assumir o papel preponderante no mercado de reciclagem de divisas (Lissakers, 1991, pp. 4043).

Até meados dos anos 60, as operações internacionais dos bancos norte-americanos representavam parcela muito pequena de suas receitas. Nos anos 50, a área internacional do Citibank - o mais internacionalizado dos bancos norte-americanos - era chamada de "Sibéria" pelos funcionários (Lissakers, 1991, p. 47). A partir dos anos 60, o surgimento do chamado "euromercado" mudou este panorama. O termo "euromercado" denominava o mercado de crédito em dólares com sede em Londres, praticamente isento de qualquer regulação por parte das autoridades norte-americanas ou britânicas. Com isso, as operações internacionais dos grandes bancos norte-americanos começaram a se avolumar. $\mathrm{O}$ choque do petróleo de 1973 deu o empurrão definitivo para o setor privado tornar-se o principal financiador dos déficits dos países em desenvolvimento. No começo dos anos 60, apenas $7,2 \%$ da demanda de recursos destes países era financiada por bancos privados. No final dos anos 70, o crédito privado internacional já respondia por $64,6 \%$ do financiamento externo destes países (ibidem, p. 59).

As operações de crédito internacional estruturavam-se em torno dos "sindicatos". Este tipo de operação tinha uma instituição líder, que fechava o negócio com o tomador e que vendia partes do empréstimo para outras instituições. Os custos de formar um "sindicato" para uma operação eram bastante baixos: segundo Alfred Vinton, gerente-geral do escritório do Morgan Guaranty em Londres, “você envia 400 telexes, obtém 200 respostas, faz as minutas dos documentos, e é isso" (Lissakers, 1991, p. 105). Os empréstimos sindicalizados permitiram que bancos menores tomassem parte da bolha de crédito internacional: para emprestar alguns milhões de dólares para um governo estrangeiro, bastavam algumas ligações ou telexes para um dos grandes money center banks. Desta forma, era mais fácil para um 
banco regional tomar parte de uma operação multimilionária de empréstimo para um país em desenvolvimento do que conceder crédito para um fazendeiro local (ibidem).

Para os grandes países em desenvolvimento, o financiamento privado representava uma forma de escapar dos limites, condições e restrições impostos pelas fontes oficiais e, assim, realizar grandes investimentos e continuar a crescer a despeito do aumento acentuado do preço do petróleo desde 1973. Até os anos 70, estes países não tinham acesso a financiamento privado mas, graças ao choque do petróleo e aos "petrodólares" reciclados pelos bancos, eles passaram a dispor de cada vez mais crédito internacional a despeito de suas condições macroeconômicas — que, a rigor, determinam seu risco como tomadores de empréstimos — não terem melhorado consideravelmente no período.

Para os bancos, os empréstimos internacionais eram mais lucrativos do que os domésticos. O governo dos EUA, por seu turno, incentivava o movimento de expansão do crédito privado, considerado "natural", pois acreditava que as decisões de crédito seriam mais eficientes se tomadas pelo mercado (Wellons, 1987, p. 109, Lissakers, 1991, pp. 59-60). As autoridades supervisoras do sistema bancário adotaram uma postura cautelosa com relação a práticas que poderiam ser consideradas pouco prudentes (Wellons, 1987, cap. 3). O incentivo do governo norte-americano a estas operações era entendido, pelos bancos, como uma garantia implícita, o que reduzia a percepção de risco destas operações. Ou seja, os bancos percebiam que perdas eventualmente incorridas no mercado internacional seriam, de alguma forma, cobertas pelos países industrializados (Dooley, pp. 5-10, Kahler, 1985, pp. 366-367).

A "estagflação" da economia norte-americana nos anos 70 também colaborou para incentivar o aumento das operações internacionais. Para os bancos, a redução do crescimento econômico nos países centrais tornou as operações de empréstimo para países em desenvolvimento mais lucrativas em comparação com as operações domésticas. Para os devedores, a aceleração da inflação norte-americana fez com que as taxas de juros reais $e x$ post das operações internacionais chegassem a ser negativas. Ademais, os créditos privados permitiam que estes países mantivessem inalterado seu ritmo de desenvolvimento econômico, a despeito do preço mais alto do petróleo.

Impulsionadas por este conjunto de fatores, as operações internacionais de crédito para tomadores soberanos explodiram nos anos 70, caracterizando uma verdadeira bolha. As áreas internacionais dos grandes bancos, antes relegadas a papel secundário, ganharam posição de prestígio e poder e passaram a atrair os funcionários mais jovens e ambiciosos. Os lucros dos 
grandes bancos nas operações internacionais levaram as instituições menores a entrar no segmento, sem avaliar corretamente os riscos. Segundo Vinton, nos grandes bancos "havia um monte de pessoas medíocres em ascensão, tomando as decisões. Outros bancos, como carneirinhos, seguiram a liderança do que pensavam que eram instituições de prestígio" (Lissakers, 1991, p. 105).

O resultado foi um verdadeiro "efeito manada", no qual o interesse individual de cada banco era continuar emprestando, independentemente do risco objetivo dos tomadores, para manter uma lucratividade similar à dos outros bancos. Mesmo os bancos mais prudentes deixaram de basear suas decisões de crédito exclusivamente no risco dos países devedores. Um exemplo é a estratégia adotada pelo banco regional Wells Fargo a partir do final dos anos 70, quando os primeiros sinais de perigo começaram a aparecer. Segundo esta estratégia, o Wells Fargo manteria sempre uma exposição um pouco menor do que a dos money center banks, pois, desta forma, "quando os torpedos começarem a vir, os grandes navios serão os primeiros a serem atingidos", ou seja, se houvesse uma crise, os grandes bancos entrariam em dificuldade primeiro e isso daria início a uma intervenção do governo norte-americano para salvá-los, o que também ajudaria os bancos menos expostos (Lissakers, 1991, p. 87).

Com tanto dinheiro à disposição, os tomadores não precisavam se preocupar sequer em pagar os juros das dívidas. Como afirmou Fernão Bracher,

Estava claro para todos que [...] o Brasil continuaria a pegar emprestado e que o mercado forneceria o dinheiro para o serviço da dívida. O Brasil não pagou um centavo de seu bolso até 1982. O dinheiro sempre era fornecido pelo mercado. Todo mundo assumia que isso ia

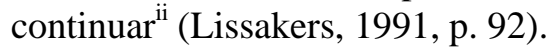

Como em toda bolha, o processo aumentava o risco sistêmico. Os limites legais aos empréstimos internacionais deixaram de ser considerados balizas de prudência e passaram a ser vistos como metas a atingir - e, se possível, exceder. Enquanto as dívidas dos países em desenvolvimento aumentaram à taxa média de $21,7 \%$ ao ano ${ }^{51}$, sua capacidade exportadora não cresceu na mesma proporção. Como alertava o FMI em seu relatório anual de 1977,

$\mathrm{O}$ acesso a fontes privadas de financiamento de balança de pagamentos pode [...] em certos casos permitir aos países adiar a adoção de medidas adequadas de estabilização doméstica. Isto pode exacerbar o problema do desequilíbrio da balança de pagamentos e pode levar a ajustes que causarão rupturas políticas e sociais quando a introdução de medidas de estabilização se tornar inevitável ${ }^{\mathrm{iii}}$ (p. 41, apud Cohen, 1982, p. 472).

Do lado dos bancos, o acúmulo de créditos para um número restrito de países aumentava a exposição das instituições aos principais devedores. Como afirmou um executivo

\footnotetext{
${ }^{51}$ Cf. Bogdanowicz-Bindert (1985), p. 261.
} 
de um banco de Nova York, "na exuberância do momento, perdemos de vista um dos fundamentos da atividade bancária — diversificação de carteira" (Lissakers, 1991, p. 95). Não havia dados confiáveis sobre as dívidas agregadas, de maneira que não era possível determinar exatamente quanto cada país devia no mercado internacional.

Em 1979, o mercado internacional receberia dois golpes que se provariam fatais. O primeiro foi o segundo choque do petróleo, causado pelo pânico que se seguiu à interrupção da produção de petróleo no Irã durante a revolução que derrubou o xá Reza Pahlevi. Entre abril de 1979 e abril de 1980, o preço do barril do óleo cru sofreria elevação de quase 150\%, saltando de cerca de US\$16,00 para US\$ 39,50. O segundo foi a decisão do presidente do Fed, Paul Volcker, no começo de outubro, de controlar a oferta da moeda e deixar as taxas de juros flutuarem livremente, com o objetivo de controlar a inflação e restaurar a confiança no dólar. A taxa de juros subiu rapidamente, atingindo 21,5\% no final de 1980.

Os dois golpes deteriorariam o balanço de pagamentos dos países devedores: o segundo choque do petróleo aumentaria ainda mais o ônus de suas importações de petróleo, enquanto o "choque Volcker" aumentaria dramaticamente o custo da dívida externa dos países em desenvolvimento, bem como causaria uma recessão nos EUA que reduziria os preços das commodities e as receitas de exportação destes mesmos países. A conta de petróleo dos países subdesenvolvidos subiu 156\% entre 1978 e 1982 (de US\$ 26,0 bilhões para US\$ 66,7 bilhões), ao passo que o preço dos produtos primários (exceto petróleo) caiu 15\% apenas em 1981, e mais $12 \%$ no ano seguinte (Velloso, 1986, p. 181).

A partir de então, o endividamento dos países em desenvolvimento cresceria aceleradamente, tanto em níveis absolutos quanto em proporção às suas exportações e ao seu produto interno. A Tabela 4.1 compara os níveis de endividamento de seis países da América Latina em 1980 e 1982. Segundo uma estimativa de Pedro Pablo Kuczynski, em meados de 1982 o débito dos países da região atingia US\$ 295 bilhões $\left(1982\right.$, p. 349) ${ }^{52}$. Segundo João Paulo dos Reis Velloso, o endividamento dos países subdesenvolvidos importadores de petróleo (incluindo México e Egito, dois produtores recentes) chegava a US\$ 612 bilhões no final de 1982 - um aumento de 82\% sobre a dívida em 1978, que somara US\$ 336 bilhões (Velloso, 1986, p. 181).

\footnotetext{
${ }^{52}$ Deste montante, segundo Kuczynski, US\$ 90 bilhões eram devidos pelo México, US\$ 75 bilhões pelo Brasil, US\$ 30 bilhões pela Argentina e pela Venezuela e US\$ 15 bilhões pelo Chile. Segundo outras estimativas, o Brasil devia entre US\$ 80 bilhões e US\$ 85 bilhões, montante similar ao devido pelo México. Os dados agregados, de qualquer forma, eram pouco confiáveis, o que também contribuiu para o acúmulo de dívidas.
} 
Tabela 4.1

Níveis de endividamento de países selecionados

\begin{tabular}{lcccc}
\hline & \multicolumn{2}{c}{ Relação } & \multicolumn{2}{c}{ Relação } \\
& $\mathbf{1 9 8 0}$ & $\mathbf{1 9 8 2}$ & $\mathbf{1 9 8 0}$ dívida/PIB (\%) & $\mathbf{1 9 8 2}$ \\
\hline Argentina & 242,4 & 447,3 & 48,4 & 83,8 \\
Brasil & 304,8 & 395,4 & 30,6 & 36,1 \\
Colômbia & 117,1 & 204,3 & 20,9 & 26,9 \\
Chile & 192,5 & 335,9 & 45,2 & 76,7 \\
México & 259,2 & 311,5 & 30,3 & 52,5 \\
Venezuela & 131,9 & 159,8 & 42,1 & 41,4 \\
\hline
\end{tabular}

Fonte: Cohen (1992).

Os primeiros sintomas dos desequilíbrios no mercado financeiro internacional foram sentidos na Polônia. No final de 1980, o país - que não era membro do FMI — devia mais de US\$ 25 bilhões a governos de países ocidentais e a cerca de 500 bancos comerciais, com destaque para os sediados na Alemanha Ocidental e na Áustria. No começo de março de 1981, o governo polonês, sem condições de honrar suas dívidas, procurou seus credores para renegociá-las. Os credores oficiais concordaram em reescalonar US\$ 2,2 bilhões em juros que venceriam durante o ano. Os bancos oficiais montaram uma "força-tarefa multinacional", composta por 20 bancos, para conduzir as negociações com as autoridades polonesas. As negociações demoraram mais de um ano, e chegaram a ser interrompidas, em dezembro de 1981, pela declaração de lei marcial e a repressão ao movimento Solidariedade. Em abril de 1982, um acordo foi fechado, sem a participação do Fundo ou de outras organizações internacionais (Boughton, 2001, pp. 320-321).

\subsubsection{O CONTEXTO POLÍTICO NORTE-AMERICANO}

Nos EUA, o choque Volcker e o aumento do preço do petróleo também se fizeram sentir. O aumento dos juros causou uma recessão em 1980 que foi um dos fatores que contribuíram para a derrota do presidente Jimmy Carter nas eleições de novembro.

Ronald Reagan, o novo presidente, não era uma figura do establishment político, ao contrário de seus antecessores republicanos Dwight Eisenhower, Richard Nixon e Gerald Ford. Reagan era um integrante do "movimento conservador" que surgira nos anos 50 e, como tal, sentia-se herdeiro direto de Barry Goldwater, candidato republicano à presidência em 1964. Goldwater, distante demais do centro político, sofrera uma derrota massacrante e 
humilhante em 1964. Mas o mundo - ou pelo menos os EUA — mudara desde então. As rápidas mudanças culturais dos anos 60 - representadas pela contracultura, pela revolução sexual e pela oposição à guerra do Vietnã - fortaleceram a corrente conservadora do Partido Republicano. Da mesma forma, a derrota no Vietnã, a crise do petróleo e as dificuldades enfrentadas pela política externa de Jimmy Carter criaram espaço para uma direita mais militarista e que defendia abertamente a confrontação com a União Soviética. Por fim, a estagnação econômica, o aumento da inflação e a crise do Estado de Bem-Estar norteamericano - representada pela quebra da cidade de Nova York, em 1975 — abriram caminho para a corrente da chamada supply side economics, formada por conservadores radicais em política econômica que viam no Estado a raiz de todos os problemas econômicos e, por isso, propunham sua redução para o mínimo tamanho possível. Com Reagan, os supply siders chegaram ao poder e passaram a controlar a política econômica dos Estados Unidos.

Ao assumir a presidência, Reagan propôs um ambicioso programa de cortes orçamentários e redução de impostos. O objetivo, de acordo com o ideário conservador da supply-side economics, era forçar a diminuição do tamanho do Estado por meio da redução de suas receitas. Aproveitando-se do capital político e do poder de agenda derivados do fato de ter obtido uma vitória acachapante sobre $\operatorname{Carter}^{53}$, Reagan conseguiu obter do Congresso a aprovação de um orçamento que reduzia os gastos públicos em cerca de US\$ 35 bilhões com relação ao ano anterior (Greider, 1981, Sinclair, 1985). O governo também conseguiu a aprovação de grandes cortes de impostos, especialmente para as empresas e para os contribuintes com mais renda, com o argumento que os impostos para estes contribuintes estavam tão altos que uma redução nas alíquotas teria o efeito de aumentar o volume total de impostos arrecadados, porque reduziria a sonegação, incentivaria o investimento e aceleraria o crescimento econômico.

As expectativas dos supply-siders, porém, não se concretizaram. Depois de uma breve recuperação nos primeiros meses do governo Reagan, a economia do país voltou a se contrair a partir de julho de 1981, quando a inflação chegou a $14 \%$ ao ano e a taxa de juros atingiu 20\%. O desemprego, que em janeiro de 1981 era de 7,5\%, em novembro de 1982 atingiria $10,8 \%$ da força de trabalho. Da mesma forma, o desempenho fiscal da nova política econômica foi decepcionante. A arrecadação caiu muito mais do que os gastos, e o déficit público explodiu de US\$ 79 bilhões em 1981 para US\$ 128 bilhões em 1982, o que 
representou 4\% do PIB norte-americano neste ano (Office of Management and Budget, 2009, p. 22, 24).

A crise econômica erodiu a popularidade de Reagan e o apoio ao governo no Congresso, enquanto o aumento do déficit público colocou o governo na defensiva. Em fevereiro de 1982, já sabendo que o déficit daquele ano atingiria uma proporção do PIB até então inédita em tempos de paz, a Casa Branca enviou uma proposta orçamentária que cortava os gastos em US\$ 60 bilhões e aumentava os impostos em US\$ 50 bilhões. A proposta foi considerada irrealista pelos principais senadores republicanos, e o Congresso rapidamente a modificou profundamente, reduzindo os cortes de gastos para US\$ 30 bilhões e dobrando os aumentos de impostos, para quase US\$100 bilhões. O novo projeto de lei foi apoiado por Reagan, mas foi recebido com hostilidade pela ala conservadora do Partido Republicano - cujos membros, ironicamente, tinham em grande parte sido eleitos na esteira da vitória de Reagan em 1980 - , que acusou o presidente de trair os princípios conservadores que o elegeram. A disputa entre os conservadores republicanos e o governo Reagan, que se arrastaria até o final de agosto, seria caracterizada como "uma luta pela alma do Partido Republicano", pelo então deputado Newt Gingrich (Newsweek, 1982).

Para aprovar o novo orçamento, Reagan teve de envolver-se pessoalmente nas negociações e buscar apoio no Partido Democrata. "Se alguns de vocês estão confusos, eu entendo", disse o presidente, em pronunciamento na televisão em 16 de agosto de 1982, ao justificar a reversão de sua promessa de não subir impostos (Economist, 1982a). A proximidade das eleições para a Câmara de Representantes, que ocorreriam em novembro, ajudou a enrijecer a posição dos conservadores, que preferiram confrontar Reagan a desapontar seus eleitores. Em 20 de agosto, o Congresso finalmente aprovou o orçamento, por margens apertadas: 52 a 47 no Senado e 226 a 207 na Câmara (Broder, 1982). Poucos dias depois, Reagan vetou uma lei de apropriações suplementar de cerca de US\$ 14 bilhões, afirmando que ela seria um "estourador de orçamento"; porém, ao retornar do recesso, em setembro, o Congresso derrubou o veto presidencial (Sinclair, 1985, p. 298).

Enquanto a batalha do orçamento aproximava-se do final, outra luta se iniciava nos bastidores. A poucos dias da votação final do orçamento, autoridades mexicanas procuraram seus interlocutores norte-americanos e levaram a má notícia: o México precisava de ajuda imediata, ou a própria estabilidade do sistema financeiro estaria em risco.

\footnotetext{
${ }^{53}$ Reagan conquistou $50,7 \%$ do total de votos populares e 489 votos no Colégio Eleitoral, ao passo que Carter
} 


\subsubsection{O MÉXICO QUEBRA}

A situação do México começou a se deteriorar no início de 1982. Suas reservas diminuíam em ritmo preocupante e as autoridades mexicanas se deram conta de que seria questão de tempo até que elas se esgotassem e o país se visse impossibilitado de cumprir seus compromissos externos. Diversas medidas foram tentadas para frear a perda de divisas, mas não foram suficientes. À medida que diminuíam as reservas, aumentava o risco de crédito para o México e, com ele, as taxas de juros cobradas pelos bancos.

Durante o primeiro semestre, Silva Herzog tentou diversas vezes sensibilizar o Departamento do Tesouro para a dificuldade de financiamento do México. Afinal, situação similar, embora em menor escala, havia ocorrido em 1976, e na ocasião o Tesouro intermediara a negociação de um pacote do México com o Federal Reserve e com o FMI que evitara uma crise. Mas, desta vez, o Tesouro preferiu manter-se afastado do problema. Como afirmou um funcionário do Tesouro, "Silva Herzog descrevia os problemas para Don Regan, e Regan não pegava a mensagem" (Kraft, 1984, p. 5). Silva Herzog procurou, também, sensibilizar Paul Volcker, que repetidamente o aconselhou a buscar um acordo com o FMI.

Em junho, o Bank of America teve dificuldade em vender um empréstimo jumbo sindicalizado de US\$ 2,5 bilhões, mesmo a uma taxa de juros bastante alta. Para Silva Herzog, isso sinalizou que a insolvência era inevitável e estava próxima. Silva Herzog então montou um pequeno comitê consultivo, formado pelo diretor do Departamento de Crédito Público, Angel Gurria, pelo diretor do Banco Central, Miguel Mancera, e pelo vice-diretor, Alfredo Phillips Olmedo.

O comitê concluiu que o país tinha três opções. A primeira seria o default simplesmente não pagar os compromissos e desafiar os credores. Segundo Phillips, "esta [opção] era a bomba atômica, a arma definitiva", e que por isso seria reservada como último recurso, "depois que alguma outra coisa tivesse sido tentada" (Kraft, 1984, p. 4). A segunda opção era procurar uma solução técnica, não-política, junto ao FMI, aos ministérios da fazenda e aos bancos centrais dos países desenvolvidos. A terceira opção, finalmente, era fazer um gesto político que provocasse uma grande crise e mobilizasse diretamente o governo dos EUA.

Silva Herzog tentou inicialmente a segunda alternativa. Esta tentativa esbarrou em dois problemas: primeiro, a relutância do presidente José López Portillo em fechar outro 
acordo com o FMI a poucos meses do encerramento de seu mandato; segundo, o tempo necessário para se negociar um acordo com o Fundo. Ainda em julho, o ministro da Fazenda mexicano convidou o FMI a enviar uma missão não-oficial para iniciar conversas com vistas à obtenção de um acordo. Para acelerar o processo e reduzir o custo político do acerto, a idéia era que o Fundo apenas concedesse seu "selo de aprovação" sem necessariamente empresar recursos, que seriam fornecidos pelos bancos. O FMI serviria, assim, apenas como uma agência de classificação de crédito que atestaria que o governo mexicano estava tomando medidas para aumentar sua capacidade de pagamento e que, portanto, era um tomador de empréstimos confiável.

Larosière, porém, negou-se a aceitar que, em troca de não comprometer seu dinheiro na operação, o Fundo aceitasse condições menos rígidas por parte do governo mexicano. De qualquer forma, nem Larosière nem o Conselho Executivo do Fundo consideravam que uma crise era iminente naquele momento, e portanto não tinham pressa em chegar a um acordo (Boughton, 2001, pp. 286-288).

Em 23 de julho, Silva Herzog encontrou-se com Regan e fez uma avaliação detalhada da situação financeira do México. Regan limitou-se a considerar a situação "séria" e recomendar que o México tomasse medidas corretivas. Despediu-se dizendo "vejo-o em Toronto" (em referência à reunião anual do FMI e Banco Mundial que seria realizada em setembro em Toronto), ao que Silva Herzog respondeu "talvez antes". Regan esquivou-se respondendo "se você vier antes, me avise com antecedência", o que convenceu Silva Herzog de que o Tesouro não faria nada se não fosse forçado a agir por uma crise (Kraft, 1984, pp. 11-12).

No dia 4 de agosto, o Banco do México usou os US\$ 700 milhões de sua linha de swap com o Federal Reserve. Ao contrário de outras três operações similares já realizadas no mesmo ano no final de abril, de junho e de julho, desta vez o Banco do México solicitou três meses de prazo para restituir o dinheiro utilizado (Kraft, 1984, p. 8, Boughton, 2001, p. 289). No dia seguinte, foi instituído um sistema de câmbio em dois níveis, que visava a isolar as operações comerciais das operações especulativas. No dia 9, negociações entre México e FMI começaram formalmente com vistas a um pacote de três anos no âmbito do Extended Fund Facility no valor de DES 3,6 bilhões (Boughton, 2001 p. 289, Kraft, 1984, p. 4). A intenção dos negociadores era chegar a um acordo até o final do mês. 
Mas já era tarde demais. No dia 11, uma quarta-feira, Silva Herzog foi informado que os bancos comerciais se negavam a rolar os débitos que venceriam na segunda-feira seguinte, dia 16. Como o Banco do México não tinha reservas suficientes para realizar estes pagamentos, Silva Herzog viu-se obrigado a lançar mão da terceira alternativa aventada pelo comitê consultivo, e gerar um fato político que envolvesse as autoridades norte-americanas diretamente. Foi o que ele fez ao ligar para Larosière, Regan e Volcker em 12 de agosto, depois de enviar uma carta aos credores privados informando-os de que país estava impossibilitado de realizar os pagamentos previstos. No dia seguinte, ele já estava em Washington para encontrar-se pessoalmente com eles e pedir ajuda (Boughton, 2001, pp. 289290).

\subsection{O RISCO SISTÊMICO E AS ALTERNATIVAS DO GOVERNO}

Silva Herzog embarcou para Washington na noite de 12 de agosto, com o propósito de pedir ajuda aos EUA para evitar um default. Na sexta-feira, dia 13, Silva Herzog encontrou-se com Larosière no FMI, com Volcker no Fed e com Regan no Tesouro. A todos transmitiu uma avaliação da posição financeira do México e pediu auxílio.

Tanto Larosière quanto as autoridades norte-americanas entenderam que a situação do México representava uma ameaça ao sistema financeiro norte-americano. A exposição dos nove money center banks ao México correspondia a 44\% do seu capital. Os empréstimos dos 15 maiores bancos regionais norte-americanos ao México correspondiam a 35\% de seu capital, e alguns destes bancos tinham emprestado cerca de $100 \%$ de seu capital ao país. O sistema financeiro norte-americano já se encontrava em um momento difícil, depois das falências do Drysdale e do Penn Square, que colocaram o Chase, o Continental Illinois e o Crocker de São Francisco em dificuldades. (O Continental Illinois acabaria indo à falência em 1984.)

Neste contexto já delicado, um default mexicano teria efeitos imediatos sobre os principais bancos dos EUA. Para piorar, os problemas no México certamente comprometeriam a capacidade de financiamento do Brasil, cuja dívida externa tinha dimensões similares à mexicana (Kraft, 1984, p. 9). Como se pode depreender da Tabela 4.2, um default simultâneo do México e do Brasil quase certamente levaria alguns dos principais bancos norte-americanos à insolvência. 
Em 13 de agosto, as autoridades norte-americanas sabiam que estavam diante de uma situação que poderia evoluir para uma crise sistêmica como descrita por Charles Kindleberger (2000): o default de um grande devedor causaria a quebra de um ou mais grandes bancos, o que levaria ao colapso da confiança no sistema financeiro e culminaria em uma grande contração da atividade econômica (Kahler, 1985, p. 357).

Tabela 4.2

Exposição como porcentagem do capital dos seis maiores bancos dos EUA ao final de 1982

\begin{tabular}{lcccccc}
\hline & Argentina & Brasil & México & Venezuela & Chile & Total \\
\hline Citibank & 18,2 & 73,5 & 54,6 & 18,2 & 10,0 & 174,5 \\
Bank of America & 10,2 & 47,9 & 52,1 & 41,7 & 6,3 & 158,2 \\
Chase Manhattan & 21,3 & 56,9 & 40,0 & 24,0 & 11,8 & 154,0 \\
Morgan Guaranty & 24,4 & 54,3 & 34,8 & 17,5 & 9,7 & 140,7 \\
Manufacturers Hanover & 47,5 & 77,7 & 66,7 & 42,4 & 28,4 & 262,8 \\
Chemical & 14,9 & 52,0 & 60,0 & 28,0 & 14,8 & 169,7 \\
\hline
\end{tabular}

Fonte: Cline (1984), pp. 13 e 24.

É importante entender as alternativas à disposição das autoridades norte-americanas neste momento. O primeiro curso de ação possível era a inação - fazer nada na expectativa de que o mercado se auto-regulasse. Foi a alternativa preferida por Regan até que Silva Herzog colocou-o frente a frente com um default. Se o México entrasse em moratória, as conseqüências para a economia norte-americana seriam fortes e rápidas. A legislação norteamericana obrigava os bancos a reclassificarem as dívidas, depois de três meses sem pagamento de juros, como "sem retorno" (non-accruing), e seu montante deveria ser considerado perdido. Desta forma, um default mexicano reduziria rapidamente o capital dos bancos envolvidos no valor das dívidas consideradas "sem retorno". Como os money center Banks tinham emprestado ao México, sozinho, o equivalente a $44 \%$ de seu capital, um default poderia causar rápida redução da oferta de crédito nos EUA, a quebra de um ou mais grandes bancos, uma crise de credibilidade do sistema bancário e, finalmente, o agravamento da recessão. Nesta situação, o Fed seria obrigado a injetar bilhões de dólares em créditos, o Tesouro teria de nacionalizar os bancos que quebrassem e promover, por meio de empréstimos, a absorção dos bancos mais frágeis pelos bancos mais fortes. De fato, segundo William Isaac, presidente da FDIC entre 1981 e 1985, “nós desenvolvemos planos de contingência para nacionalizar" os grandes bancos, caso um dos grandes devedores declarasse 
moratória (Isaac, 2008). Podia-se prever, naquele momento, que o custo da inação seria o aprofundamento da crise econômica e, em decorrência do desastre econômico, a imobilização política do governo Reagan. Segundo Isaac, caso ocorresse um default, "o país teria ido de uma recessão severa para uma depressão" (ibidem).

Um segundo curso de ação possível era um salvamento direto dos bancos, por meio de uma operação estritamente no nível doméstico norte-americana. Uma possibilidade seria o Tesouro comprar, com algum desconto, os créditos "podres" nas mãos dos bancos; isto limparia os balanços dos bancos e deixaria ao governo a tarefa de cobrar a parte devida aos bancos norte-americanos da dívida dos países em desenvolvimento. Operação nesta linha foi empreendida pelo governo norte-americano entre 2008 e 2009, por meio do TARP. Outra possibilidade seria um aumento de capital dos bancos, que receberiam recursos públicos em troca de ações. Por fim, uma terceira possibilidade seria o financiamento público para que instituições mais saudáveis incorporassem bancos insolventes. Estas possibilidades evitariam a falência das instituições financeiras e teriam menor impacto econômico, mas também representariam um enorme custo político. Como ambas as possibilidades exigiram a infusão de dinheiro público, o Congresso teria de autorizar e apropriar os fundos necessários, num processo de debates e votações que poderia se arrastar por meses.

O terceiro curso de ação seria "exportar" o problema, tratando-o no nível externo. Neste caso, uma possibilidade seria oferecer, ao México, meios de manter o serviço de sua dívida. Como o mercado financeiro se recusava a continuar financiando o México, recursos públicos teriam de ser usados de qualquer forma. No entanto, o volume de recursos necessários, pelo menos no curto prazo, seria bem menor do que se o problema fosse internalizado, pois bastaria emprestar ao México o suficiente para manter o serviço de sua dívida e assim ver a exposição dos grandes bancos norte-americanos reduzir-se gradativamente. Analogamente, podia-se prever que o custo político desta alternativa seria menor. Este curso de ação, como veremos, foi o escolhido.

\subsubsection{O GOVERNO DOS EUA MONTA O PACOTE}

A primeira reunião de Silva Herzog foi realizada no FMI. De Larosière disse-lhe que o Fundo estava preparado para ajudar o México, mas isso dependeria de um acordo a ser negociado nas semanas seguintes. E o FMI não poderia fechar um pacote com o país se este deixasse de pagar os bancos (Boughton, 2001, pp. 290-291). Em resumo, o FMI só poderia 
fazer algo pelo México se Silva Herzog obtivesse um pacote de ajuda de outras fontes oficiais até segunda-feira.

A seguir, Silva Herzog encontrou-se com Volcker. O presidente do Fed mostrou-se preocupado com a possibilidade de que a situação do México, por envolver os maiores bancos norte-americanos, pudesse causar um pânico financeiro nos EUA. Afirmou que era fundamental que o México mantivesse os pagamentos de juros, com o que Silva Herzog concordou. Por fim, Volcker tratou do financiamento de emergência. A linha de swap de US\$ 700 milhões já fora usada. Volcker afirmou ser capaz de obter, na semana seguinte, até US\$ 1,5 bilhão de diversos bancos centrais por meio do BIS, e no decorrer do dia marcaria uma reunião de emergência com representantes dos bancos centrais dos principais países industrializados, na sede da instituição, para o dia 18, quarta-feira (Kraft, 1984, p. 9-10).

Mas ainda restava a necessidade imediata de fundos para pagar os compromissos da segunda-feira. Nem o FMI, nem o Fed, podiam oferecer os recursos em prazo tão curto. Restava apenas o Departamento do Tesouro.

Silva Herzog encontrou-se com Regan no Tesouro logo depois do almoço. A seguir, técnicos mexicanos e norte-americanos se reuniram para identificar com exatidão os débitos a vencer nas semanas seguintes. No fim do dia, chegou-se à conclusão que o México precisaria de US\$ 3,5 bilhões, dos quais US\$ 1,5 bilhão viria do pacote a ser organizado por Volcker no âmbito do BIS, e US\$ 2 bilhões seriam levantados diretamente pelo Tesouro entre diversas agências domésticas norte-americanas e estariam disponíveis para o país já na segunda-feira.

Metade do pacote do Tesouro viria de um crédito de US\$ 1 bilhão, concedido pela Commodity Credit Corporation para importação de alimentos (Boughton, 2001, p. 292). Este instrumento já tinha sido usado anteriormente, inclusive no pacote de 1976, e desta vez o negócio foi fechado por telefone entre o vice-secretário do Tesouro, Tim McNamar, o secretário de Agricultura, John Block.

A outra metade do pacote mostrou-se mais difícil de obter. A idéia era que fazer uma compra antecipada de petróleo mexicano, no valor de US\$ 1 bilhão. Obtido o aceite do Departamento de Energia, verificou-se que apenas a Reserva Estratégica de Petróleo poderia fazer uma compra tão grande, mas os recursos só estariam disponíveis para o México em cinco dias. Para viabilizar o negócio, o Tesouro adiantou ao México US\$ 1 bilhão em recursos do Exchange Stabilization Fund, que por sua vez receberia diretamente o pagamento da Reserva Estratégica. Isto criava outro problema: o uso do ESF requeria aprovação do 
Escritório de Administração e Orçamento (Office of Management and Budget, OMB), órgão também ligado ao Executivo. O OMB aprovou a operação em princípio, mas, temendo uma reação do Congresso, exigiu que os termos do empréstimo fossem melhores do que os vigentes no mercado para que a operação pudesse ser justificada perante o Legislativo.

Esta exigência causou um impasse que por pouco não levou ao fracasso das negociações. No sábado, os norte-americanos propuseram uma operação cujo custo financeiro, para o México, equivalia a 35\%. A delegação mexicana entrou em contato com López Portillo, que julgou os termos inaceitáveis. No domingo, a delegação norte-americana fez nova proposta, na qual os juros eram nominamente reduzidos para $18 \%$, mas o Tesouro cobraria uma taxa antecipada, a título de "administração", de US\$ 100 milhões. Os mexicanos se enfureceram: a cobrança de uma taxa de administração era uma tática comum e pouco criativa para embutir juros numa operação de empréstimo sem declará-los explicitamente. Neste caso, os custos financeiros dos novos termos propostos eram idênticos aos da proposta do dia anterior. Silva Herzog ligou para López Portillo, explicou a proposta e pediu permissão para abandonar as negociações. López Portillo concordou: "deixe Roma queimar", disse. Silva Herzog então informou os norte-americanos que considerava encerradas as negociações e que iria retornar para o México à tarde.

Após a saída de Silva Herzog, os norte-americanos voltaram a se reunir. As autoridades do Tesouro argumentavam que Silva Herzog aceitaria o acordo se a taxa de administração fosse reduzida pela metade. Os representantes do OMB insistiam na manutenção da taxa em US\$ 100 milhões, para que o retorno do empréstimo fosse suficientemente alto para justificar a operação perante o Congresso.

Às quatro da tarde, Regan chegou ao prédio do Tesouro. Tinha viajado para Camp David pela manhã, e discutido a situação do México com o presidente Reagan. O presidente lhe disse que gostaria que o México fosse ajudado, se isso fosse tecnicamente possível. Quando voltou, encontrou o impasse entre Tesouro e OMB. Apesar do risco de ser questionado a posteriori pelo Congresso, Regan decidiu assumir pessoalmente a responsabilidade de realizar nova proposta aos mexicanos com as taxas reduzidas, passando por cima do OMB.

Silva Herzog foi localizado na embaixada do México, pronto para dirigir-se ao aeroporto, e foi-lhe feita a nova proposta. Depois de consultar novamente Lopez Portillo, ele acabou retornando ao Tesouro, onde, às oito horas da noite do domingo, fechou o acordo 
proposto por Regan (Kraft, 1984, pp. 14-16) ${ }^{54}$. Embora as condições fossem melhores do que as propostas pela manhã, o custo da operação, de cerca de $30 \%$, ainda foi bastante alto - a ponto de o presidente Reagan dizer para Regan, ao ser informado dos termos, que "você é um fdp de coração duro", ao que Regan teria retrucado "não, senhor presidente, eu só quero prestar ao contribuinte americano o mesmo tipo de serviço que eu prestei aos acionistas da Merrill Lynch". O próprio Volcker mais tarde caracterizaria o custo da operação como "flagrantemente alto" ("egregiously high"). Os mexicanos se sentiram "roubados" e tentaram em sigilo manter os termos do acordo - cujo vazamento, poucos dias depois, causou um desgate adicional ao governo López Portillo (Kraft, 1984, p. 16, Boughton, 2001, p. 292).

$\mathrm{Na}$ quarta-feira, dia 18, representantes dos bancos centrais dos países industrializados se encontraram na Basiléia para a reunião extraordinária do BIS convocada por Volcker para coordenar um empréstimo de bancos centrais da Europa, Japão e EUA para o Banco do México. Os termos iniciais tinham sido combinados com Volcker com seus homólogos da Europa e do Japão por telefone: o total do empréstimo seria de US\$ 1,5 bilhão, com o Fed respondendo por metade deste montante. Note-se que, embora a operação fosse negociada na sede do BIS, este atuaria apenas como intermediário, pois os fundos seriam emprestados pelos próprios bancos centrais.

Uma condição para o empréstimo seria a negociação do México com o FMI — o empréstimo negociado pelo BIS deveria ser pago assim que o México recebesse os primeiros recursos do Fundo. O empréstimo seria dividido em três fatias: a primeira estaria disponível no momento da assinatura do acordo, a segunda na metade de novembro e a terceira quando o México assinasse o acordo com o FMI, o que se estimava que ocorresse na metade de dezembro. O objetivo deste dispositivo, como o próprio Volcker diria alguns dias depois na reunião do Federal Open Market Committee (FOMC), era assegurar que "em nenhum momento estaremos oferecendo mais dinheiro do que os mexicanos precisam" (FOMC, 1982a, p. 3). No último minuto, a Espanha, que não havia participado da reunião do BIS, ofereceu-se para emprestar US\$ 175 milhões, e o Fed decidiu aumentar sua contribuição no mesmo valor para honrar o compromisso de arcar com metade do total do pacote, que assim foi fechado em US\$1,85 bilhão. Tecnicamente, os US\$ 925 milhões dos europeus seriam um empréstimo do BIS, enquanto a parte dos EUA seria composta de um empréstimo de US\$ 600

\footnotetext{
${ }^{54}$ A versão apresentada em Boughton (2001, p. 292) difere em alguns detalhes, mas ambas concordam que as negociações quase foram rompidas por causa da cobrança da taxa de administração, e que só foram retomadas depois que Regan interviu e elas foram reduzidas à metade.
} 
milhões do Tesouro, por meio do $\mathrm{ESF}^{55}$, e US\$ 325 milhões do Fed, por meio de um aumento na linha de swap que já existia com o Banco do México ${ }^{56}$ (Kraft, 1984, pp. 17-19, Boughton, 2001, pp. 294-296, FOMC, 1982, p. 3-4). O entendimento dos participantes era que estes empréstimos, de curto prazo, seriam os primeiros a serem pagos com os recursos liberados pelo FMI.

Restava apenas a questão das garantias que seriam fornecidas pelo governo mexicano ao BIS. A demora em se chegar a um acordo sobre isso ilustra a dificuldade em se montar o pacote com os instrumentos normalmente à disposição dos governos. A princípio, supunha-se que o México poderia garantir o empréstimo com suas reservas de ouro, mas o país não possuía quantidade suficiente do metal. A seguir, as partes decidiram garantir o empréstimo com receitas futuras de petróleo. No entanto, a Pemex já tinha a prática de garantir seus créditos comerciais com receitas futuras do produto. A área jurídica do Fed foi envolvida nas negociações, e as partes acabaram por acordar que as receitas de petróleo do México a partir de agosto de 1983 seriam a garantia para o empréstimo de US\$ 1,85 bilhão. Este processo atrasou em cerca de dez dias a assinatura do acordo (Kraft, 1984, p. 28).

A última parte desta fase inicial das negociações ocorreu entre o México e os bancos comerciais. No dia 20, Silva Herzog reuniu-se com os representantes dos bancos na sede do Federal Reserve de Nova York. Dos cerca de 800 bancos que tinham sido convidados, 115 compareceram. Também estavam presentes dois funcionários do FMI. Anthony Solomon, presidente do Fed de Nova York, abriu a reunião, fazendo alusão aos empréstimos concedidos ao México pelo Tesouro e pelos bancos centrais e indicando que o governo norte-americano esperava um resultado "construtivo" das conversas do governo mexicano com os bancos (Kraft, 1984, p. 22). A seguir, Silva Herzog fez uma apresentação sobre a situação financeira do México. Deixou claro que o país pretendia manter o seu relacionamento com a comunidade financeira internacional, e que, para isso, continuaria a pagar os juros de todas as dívidas. Ele pedia um adiamento "puramente temporário" de 90 dias para o pagamento do principal das dívidas, em termos a serem acertados mutuamente, e mais US\$ 1 bilhão em "dinheiro novo", para dar conta da balança comercial do país e recompor suas reservas.

\footnotetext{
${ }^{55}$ O Tesouro inicialmente havia emprestado US\$ 1 bilhão em recursos do ESF ao México, mas seria ressarcido em poucos dias pela Reserva Estratégica de Petróleo, que pagou US\$ 1 bilhão adiantado por petróleo mexicano. Desta forma, uma vez finalizada a operação com a Reserva Estratégica, o Tesouro poderia novamente emprestar recursos do ESF para o México. Para uma explicação da operação realizada pelo Tesouro, cf. FOMC, 1982a, pp. $9-10$.

${ }^{56} \mathrm{O}$ aumento da linha de swap dependia apenas de decisão do FOMC, que se reuniria no dia 24 de agosto.
} 
Também assegurou que o México estava em negociações com o FMI para fechar um plano de austeridade que garantiria a rápida recuperação de sua balança de pagamentos. Procurou transmitir a idéia de que o problema enfrentado pelo país era temporário, e que seria revertido em breve se houvesse a colaboração dos bancos (FOMC, 1982a, p. 2, Kraft, 1984, p. 22, Boughton, 2001, p. 297).

Diversos representantes dos bancos fizeram comentários ou pediram esclarecimentos. Os principais credores - Bank of American, Citibank, Chemical, Manufacturers Hanover, Union Bank of Switzerland e Crédit Commercial de France - manifestaram mais apoio. O entusiasmo dos representantes dos bancos pequenos era menor, mas, como diria Solomon quatro dias depois, "ninguém se levantou e disse não" (FOMC, 1982a, p. 2).

Já na tarde do mesmo dia 20, representantes dos 14 maiores credores fizeram a primeira reunião do comitê consultivo dos bancos, composto pelos norte-americanos Chase Manhattan, Chemical Bank, Citibank, Morgan Guaranty, Bank of American, Bankers Trust e Manufacturers Hanover, pelo japonês Banco de Tóquio, pelos europeus Lloyds Bank, Société Générale, Swiss Bank Corporation, Deutsche Bank, pelo canadense Bank of Montreal e pelo mexicano Banco Nacional de México. Volcker indicou pessoalmente o Citibank e o Bank of America como co-presidentes do comitê, e sugeriu que um terceiro banco, europeu, fosse o terceiro co-presidente (Parola, 1991, p. 35). A despeito de o comitê possuir três copresidentes, o papel mais relevante terminaria por recair sobre o representante do Citibank, William Rhodes (Kraft, 1984, pp. 22-23).

Em pouco mais de uma semana, um pacote de ajuda de dimensões sem precedentes no pós-guerra fora montado para impedir o default do México. Mas a crise estava apenas começando. Rapidamente o fluxo de crédito privado para os outros países do Terceiro Mundo seria cortado, e seus governos também estariam às portas do Tesouro, pedindo ajuda.

\subsubsection{ALGUMAS CONCLUSÕES PRELIMINARES}

Os eventos dos dias 12 a 20 de agosto de 1982 nos permitem chegar a algumas conclusões preliminares sobre as posições e preferências, naquele momento, dos atores envolvidos.

Do lado mexicano, estava evidente o interesse do ministério da Fazenda de manter os pagamentos, evitar um default e, assim, manter um relacionamento normal com os bancos internacionais. Para lograr este objetivo, Silva Herzog dispunha-se a fechar um plano de 
ajuste com o FMI que traria condições bastante duras. A mesma disposição não existia em outros níveis do governo, particularmente do presidente Lopez Portillo. Mesmo assim, durante todo o período, os representantes mexicanos usaram a possibilidade de default meramente como tática para extrair condições um pouco melhores de seus parceiros nas negociações. Num primeiro momento, esta possibilidade foi usada para atrair a atenção do Tesouro; a seguir, no domingo 15, Silva Herzog retirou-se das negociações porque sabia que os norte-americanos não arriscariam um default potencialmente desastroso ao seu sistema bancário no dia seguinte por causa de uma disputa de US\$100 milhões (e, ainda assim, aceitou "dividir a diferença" e pagar uma taxa inicial de US\$ 50 milhões). Na reunião com os bancos privados, Silva Herzog procurou reduzir a dramaticidade da situação, caracterizando-a como uma escassez temporária de divisas, que seria resolvida em breve com a adoção de medidas de austeridade a serem chanceladas pelo FMI.

Do lado norte-americano, sobressaem as dificuldades causadas pela pluralidade de agências envolvidas, cada uma com orçamentos próprios e regras distintas de desembolso de recursos. O Tesouro, inicialmente, preferiria manter o governo fora do problema; o subsecretário Beryl Sprinkel chegou a dizer a executivos dos bancos que "vocês emprestaram, vocês cobram" (Lissakers, 1991, p. 204). No entanto, a postura laissez-faire com relação aos bancos não durou muito: percebendo o risco ao sistema bancário, o Tesouro montaria uma operação de salvamento, mas, ainda fiel a uma convicção "bagehotiana" de que qualquer crédito oferecido pelo emprestador de última instância deveria ter um custo punitivo, cobraria muito caro do México pela ajuda ${ }^{57}$. Esta convicção, assim como o temor de um questionamento por parte do Congresso que se materializou no conflito entre Tesouro e o $\mathrm{OMB}$, levou as autoridades norte-americanas a uma posição perigosamente rígida, que quase inviabilizou o acordo com os mexicanos. Com os recursos à disposição limitados ao ESF, o Tesouro foi obrigado a articular instrumentos de crédito de outras agências governamentais, que não necessariamente compartilhavam da mesma visão do problema ou da mesma percepção quanto aos seus riscos.

$\mathrm{O}$ ator que se destaca, nesta fase inicial da crise mexicana, é o Federal Reserve, na figura de seu presidente, Paul Volcker. Por um lado, Volcker tinha a sorte de possuir um instrumento flexível e pronto para ser usado em auxílio do México - a linha de swap cambial

\footnotetext{
${ }^{57}$ Walter Bagehot é considerado o autor da idéia de que um emprestador de última instância, numa crise monetária, deve emprestar ao sistema bancário os recursos necessários para evitar um colapso, mas deve cobrar taxas elevadas para reduzir o risco moral. Cf. Boughton, 2001, pp. 291-292.
} 
do Fed, estabelecida 15 anos antes porque tratava-se de um país vizinho cuja moeda era, à época, conversível (FOMC, 1982a, pp. 5, 9). Por outro lado, Volcker parece ter entendido, desde o começo, a dimensão do risco que a crise mexicana representava para o sistema bancário norte-americano, e o horizonte temporal necessário para sua solução — ao contrário de Regan, Volcker não alimentava ilusões de que a crise seria resolvida no curto prazo. De fato, na reunião do FOMC do dia 24 de agosto, Volcker anteciparia um espalhamento da crise para outros devedores, a começar pela Argentina e continuando com Brasil e Venezuela. $\mathrm{O}$ problema, para ele, era que o Fed não dispunha de instrumentos flexíveis como o swap para auxiliar estes outros países em risco:

Argentina é o [caso] mais iminente de todos, creio eu. É uma situação diferente em muitos aspectos, mas, no que concerne a nossa própria posição, [...] nós não temos um acordo de swap com a Argentina. Nós sempre nos recusamos a estender [a rede de swaps]: esta [linha de swap] com o México é como um negócio especial com um vizinho. [...] O que o governo dos EUA gostaria de fazer no caso da Argentina é outra história. Eu imagino que se a Argentina entrar nesse tipo de apuro, a questão será levantada. Mas nós temos uma distinção [...] em nossa atitude para o México e para a Argentina [...]. Brasil, Venezuela e outros poderiam ser envolvivos também, mas eu creio que a Argentina é o caso mais iminente. Agora, a dívida deles é muito menor, evidentemente. ${ }^{\text {iv }}$ (FOMC, 1982a, p. 9).

O FMI aparece nesta fase como um ator incapaz de agir com a presteza necessária para se evitar a catástrofe. Seu processo decisório era lento, os recursos que podia oferecer ao México, limitados. Os US\$ 4 bilhões que Silva Herzog estimava poder receber do FMI - o que requereria a assinatura de um acordo que demoraria meses para ser costurado - eram apenas US\$ 150 milhões a mais do que o Tesouro, o Fed e os bancos centrais dos outros países industrializados conseguiram oferecer em uma semana. No entanto, o FMI era a entidade que poderia realizar os empréstimos a prazo mais longo, pois os mecanismos à disposição de Regan e Volcker pressupunham prazos curtos de pagamento.

É interessante notar que Volcker parecia ver o acordo do México com o FMI como a garantia de que receberia de volta os US\$ 2,55 bilhões emprestados ao país pelo ESF, pelo Fed e pelos outros bancos centrais ${ }^{58}$. Na reunião do FOMC de 24 de agosto de 1982, em resposta a questionamento levantado por Charles Partee sobre as garantias dos empréstimos, Volcker afirmou que

Eu creio que o ponto fundamental é o que você acabou de apontar: nada disso vai funcionar a não ser que haja um bom programa de ajuste [econômico]. E vai ter de ser um programa de ajuste muito draconiano. [...] Eu não sei se alguém pode julgar quanto [ajuste] o país pode agüentar. Um país pode ter um lindo programa de ajuste draconiano, mas se o país

\footnotetext{
${ }^{58}$ Refiro-me aos US\$ 700 milhões retirados em 4 de agosto pelo México da primeira linha de swap, mais o US\$ 1,85 bilhão emprestado no âmbito do BIS. Este último empréstimo, como vimos, acabou por ser garantido pelas receitas de petróleo mexicano a partir de agosto de 1983.
} 
cair em uma revolução, o programa vai fracassar. [...] Mas isso tem que ser o suporte fundamental de qualquer crédito. Nós labutamos muito nessa questão das garantias e não há nenhuma resposta muito satisfatória porque o México não tem muitas garantias [a oferecer]. Mas há respostas, satisfatórias ou não. A idéia disso é que nosso swap atual vai permanecer garantido, por assim dizer, por um acordo que ainda não existe com o Fundo. Mas se ele vier a existir, nosso swap vai ser o primeiro credor. Este segundo empréstimo - e a proposta é que este seja um empréstimo separado - será garantido, junto com o crédito do BIS, pelo restante dos recursos do Fundo à medida que eles forem liberados. Eu suponho que tenhamos [a garantia do] ouro por decorrência. Eles estão dispostos a oferecer US\$250 milhões em ouro, o que não vai muito longe, mas é o que temos. E, por meio de um arranjo ainda a ser acordado, as receitas do petróleo são um último suporte para o caso de nada mais funcionar ${ }^{\mathrm{v}}$ (FOMC, 1982a, p. 5).

Volcker, da mesma forma que enxergava no acordo do México com o FMI uma garantia aos empréstimos oficiais concedidos ao país, ainda esperava que, se o pacote de ajuda desse certo, os bancos voltariam a emprestar em breve ao México, que por sua vez usaria estes recursos para pagar os créditos oficiais que recebera. Como afirmou Volcker na mesma reunião do FOMC de 24 de agosto, "se isso realmente funcionar direito, nós seremos ressarcidos com recursos privados", pois "os bancos farão mais empréstimos e o México vai nos pagar o que nos deve". Contudo, concluiu o raciocínio com uma nota de cautela: "mas nós podemos estar sonhando, também,"vi (FOMC, 1982a, p. 11). As semanas seguintes confirmariam este seu temor.

Os bancos, finalmente, enfrentavam um claro problema de ação coletiva. Eles não emprestariam mais ao México em condições de mercado, pois o país estava assumidamente insolvente. Porém, se o país não recebesse mais empréstimos, não poderia pagar o que já devia e causaria prejuízos às instituições financeiras. Por isso, os grandes bancos, altamente expostos ao México, tinham grande interesse em manter os empréstimos ao país para evitar um default que lhes seria desastroso. Os pequenos bancos, por seu turno, tinham emprestado proporcionalmente menos ao país, e estavam mais dispostos a assumir logo prejuízos assimiláveis do que arriscar-se a perder ainda mais no futuro. A diferença de interesses entre bancos grandes e pequenos estava evidente desde a primeira reunião no Fed de Nova York, no dia 20 de agosto, quando os representantes que mostravam mais entusiasmo com as medidas propostas pelo México eram os dos money center banks.

De qualquer forma, para todos os bancos era fundamental que a capacidade de pagamento do México fosse melhorada. Por mais que coordenassem suas posições, os bancos comerciais não poderiam continuar emprestando indefinidamente a um devedor insolvente como se nenhum problema tivesse ocorrido. Daí, para o setor privado, a importância do FMI: um acordo do México com o Fundo, ao mesmo tempo em que indicava a disposição do país 
de mudar sua política econômica de maneira a gerar superávits na balança de pagamentos, lhe garantia uma fonte oficial de recursos de médio prazo que reduziria substancialmente sua necessidade de recursos privados.

Finalmente, vale ressaltar a participação quase nula de dois atores com responsabilidades sobre a política dos EUA para o México: o Departamento de Estado (DoS) e o Escritório do Representante Comercial dos EUA (USTR). O salvamento do México tinha um óbvio componente de política externa; um colapso do país vizinho certamente teria conseqüências imediatas para os EUA. Ademais, o México já era um dos maiores importadores de produtos dos EUA e, portanto, se perdesse acesso ao mercado externo, as exportações norte-americanas seriam afetadas. Da mesma forma, um plano de ajuste macroeconômico draconiano certamente reduziria as importações mexicanas de produtos norte-americanos. Ao assumir a liderança das tratativas com o México, o Tesouro manteve o DoS e o USTR praticamente fora do processo de negociação; isto pode ter lhe custado algo em termos de flexibilidade da solução, já que os instrumentos sob controle destes ministérios não participaram dos pacotes, mas teve o benefício de aumentar sua autonomia.

\subsection{OUTRAS RESPOSTAS BILATERAIS À CRISE: ARGENTINA E BRASIL}

A crise do México teve repercussões imediatas sobre os outros devedores da América Latina. Os bancos comerciais pararam de rolar automaticamente as dívidas de todos os países da região. Afinal, o México era um produtor de petróleo, tinha um governo estável de partido único e faz fronteira com os Estados Unidos. Como produtor de petróleo, tinha exportações garantidas; seu sistema político, dominado pelo PRI, parecia permitir ao governo impor programas de austeridade e mantê-los por bastante tempo; e a fronteira com os EUA garantia que o governo norte-americano viria em seu salvamento para evitar as conseqüências de um colapso do vizinho. Comparados com o México, Argentina e Brasil estavam em situação bem pior: ambos importavam petróleo, estavam em processos de transição de governos autoritários para democráticos e, geograficamente, são bem mais distantes dos EUA. E a Argentina já vivia uma crise financeira desde o início de 1981. Não é de se surpreender, portanto, que a crise mexicana tenha rapidamente atingido a capacidade de financiamento dos outros dois grandes devedores latinoamericanos.

A Argentina estava em crise econômica há alguns anos. Entre meados de 1978 e meados de 1982, a dívida externa do país triplicou. O regime cambial de crawling peg ruiu 
em fevereiro de 1981, a inflação disparou e a deterioração econômica contribuiu para a derrubada do governo do general Roberto Eduardo Viola, em dezembro do mesmo ano. Em seu lugar, o general Leopoldo Galtieri assumiu a presidência e indicou Roberto Alemann como ministro da Economia.

Alemann tomou medidas para reduzir o déficit fiscal e estabeleceu um regime de câmbio flutuante. Desta forma, esperava reduzir o déficit na balança de pagamentos. Embora os resultados iniciais tenham sido promissores, Alemann foi surpreendido pela decisão de Galtieri, anunciada em abril de 1982, de invadir as Ilhas Malvinas. Em poucos dias, a GrãBretanha congelou os ativos financeiros argentinos (a Argentina, em retaliação, fez o mesmo com os ativos financeiros britânicos), a Comunidade Européia interrompeu suas importações da Argentina e os EUA cortaram os créditos comerciais fornecidos pelo Export-Import Bank e pela Commodity Credit Corporation. Em maio, portanto ainda durante a guerra, o governo promulgou uma lei que proibia pagamentos a residentes britânicos, o que, na prática, impedia que fosse mantido o serviço das dívidas com os bancos britânicos. As sanções econômicas recíprocas e o próprio custo da guerra das Malvinas impediram a Argentina de cumprir seus compromissos com os credores externos e, quando a guerra acabou, em junho, o país já acumulava mais de US\$ 2 bilhões em atrasos com os bancos comerciais. Pouco depois, em julho, novo golpe militar derrubou Galtieri, substituído pelo general Reynaldo Benito Bignone. O novo governo marcou eleições, com a intenção de retornar o poder aos civis, para março de 1984. Como ministro da Economia, assumiu José María Dagnino Pastore.

Pastore, no entanto, ficaria no cargo por apenas 53 dias. O novo ministro tentou buscar apoio dos EUA para refinanciar suas dívidas, mas o governo norte-americano exigiu que a Argentina restabelecesse relações normais com o Reino Unido como condição para qualquer ajuda (Economist, 1982b). Frustrado com a falta de apoio político do governo militar, Pastore pediu demissão em 24 de agosto e foi substituído por Jorge Wehbe. Wehbe imediatamente decidiu buscar auxílio do FMI, que o recebeu com desconfiança: o staff do Fundo não acreditava que o governo militar conseguiria apoio político suficiente para cumprir qualquer acordo que fosse assinado, especialmente levando-se em conta que os 18 meses seguintes seriam dominados pela campanha eleitoral que decidiria o futuro do país. No dia 31 de agosto, o governo admitiu publicamente que não esperava regularizar os pagamentos dos US\$ 15 bilhões em empréstimos que venciam até o final do ano, confirmando temores dos bancos credores. A eclosão da crise mexicana mudou a disposição do FMI e, no início de setembro, 
De Larosière concordou em iniciar negociações com a Argentina. Ao mesmo tempo, o governo argentino iniciou negociações com os principais bancos credores e com o BIS para obter empréstimos de, respectivamente, US\$ 1,1 bilhão e US\$ 750 milhões (Boughton, 2001, pp. 327-333).

O Brasil, embora já tivesse iniciado um processo de ajuste macroeconômico em dezembro de 1980, também foi afetado pela crise mexicana de agosto. Os bancos comerciais imediatamente pararam de emprestar ao País. A visão do governo brasileiro era que a crise de liquidez tinha caráter temporário, e que as linhas de crédito seriam restabelecidas assim que passassem os efeitos da crise mexicana (Bacha, 1988, p. 50).

Neste momento, o Brasil possuía US\$ 6 bilhões em reservas, quantia insuficiente para pagar seus compromissos até o final do ano (Boughton, 2001, p. 335). Publicamente, as autoridades brasileiras garantiam não ter intenção de renegociar: "nosso negócio é pagar", insistia o ministro do Planejamento, Antonio Delfim Netto (Veja, 1982a, p. 122). A oposição, por seu turno, criticava a política em curso e afirmava que pagar a dívida a qualquer custo era a pior coisa a fazer nas circunstâncias (ibidem, p. 129). O debate político interno adicionava um fator de incerteza, pois em novembro seriam realizadas eleições para o Congresso Nacional, para as assembléias estaduais, para os governos estaduais, para as prefeituras e para as câmaras de vereadores. O resultado destas eleições determinaria a composição do Colégio Eleitoral que escolheria o sucessor do presidente João Figueiredo em janeiro de 1985. Tratava-se, portanto, de eleições extraordinariamente importantes. O governo brasileiro temia que iniciar negociações com o FMI depois de mais de um ano de ajustes já dolorosos levaria a uma grande derrota em novembro. Os bancos, por seu turno, temiam a instabilidade política. Lloyds Banks e Citibank ameaçavam recusar-se a rolar as dívidas já contraídas, o que causaria um default brasileiro.

No final de agosto, o presidente do Banco Central do Brasil, Carlos Langoni, viajou a Washington para encontrar-se com os presidentes do Citibank, do Morgan Guaranty e do Manufacturers Hanover. Argumentou a eles que o Brasil era "um caso completamente diferente do mexicano" (Veja, 1982c, p. 142). No entanto, o fluxo de recursos continuou a se reduzir e, em 7 de setembro, a filial do Banco do Brasil em Nova York - que centralizava as operações cambiais brasileiras — teve de ser socorrida pelos grandes bancos norteamericanos. A partir deste dia, o Banco do Brasil teria sucessivas dificuldades para fechar suas operações, dependendo sempre de operações extraordinárias no mercado interbancário 
de Nova York. No dia 8 de setembro, Langoni tentou tranqüilizar o mercado garantindo publicamente que o Brasil atravessaria esse período de dificuldades financeiras, que ele julgava duraria até dezembro, com "relativa facilidade" (ibidem, p. 143). Mas a situação continuou a se deteriorar e, no final de setembro, as autoridades brasileiras pediram ajuda às norte-americanas.

Paul Volcker foi o primeiro a entrar em ação, organizando uma reunião dos dirigentes dos maiores bancos com autoridades do Fed, do Tesouro e do FMI. Nesta reunião, os bancos que se mostravam dispostos a reduzir abruptamente seus créditos ao Brasil foram convencidos a continuar operando normalmente com o País e a organizar um grupo consultivo que, a exemplo do que tinha sido montado para o México, seria formado para manter o Brasil solvente (Boughton, 2001, p. 338).

Na terceira semana de setembro, o presidente Figueiredo viajou a Nova York para abrir a sessão da Assembléia Geral da ONU. Dois dias antes, os ministros do Planejamento, Delfim Netto, e da Fazenda, Ernani Galvêas, embarcaram para Washington para conversar com autoridades do Tesouro e do Fed. Depois de discursar na AGNU, Figueiredo reuniu-se com o secretário de Estado, George Schultz, e pediu um empréstimo dos EUA para evitar um default brasileiro. Em negociações diretas de Delfim e Galvêas com Donald Regan, foi acertado um crédito de US\$ 1,25 bilhão do ESF para o país, dois quais US\$ 500 milhões seriam liberados em 27 de outubro e o restante em meados de novembro (Veja, 1982b, pp. 3233). A operação foi mantida em sigilo e só seria revelada durante a visita do presidente Ronald Reagan ao Brasil em $1^{\circ}$ de dezembro (Veja, 1982c, pp. 142-147).

Com o empréstimo do Tesouro, a redução das reservas e a rolagem dos empréstimos que venceram, o país conseguiu atravessar o período de campanha eleitoral sem atrasar os pagamentos ou ver-se obrigado a uma moratória. Negociações com o FMI começaram apenas depois do dia 15 de novembro, quando foram realizadas as eleições (Boughton, 2001, pp. 338-339).

Neste ponto, é importante notar o contraste entre o tratamento concedido pelo governo norte-americano ao México e o tratamento concedido à Argentina e ao Brasil. A Argentina só conseguiu recursos por meio do BIS. Ademais, embora o total de sua dívida fosse de cerca de US\$ 30 bilhões (35\% da dívida mexicana), seu pacote de ajuda oficial representou apenas $19 \%$ da ajuda concedida ao México. A comparação com o Brasil é ainda mais emblemática. Os dois países estavam endividados em nível similar (entre US\$ 80 bilhões e US\$ 90 bilhões). 
A exposição dos grandes bancos norte-americanos aos dois países era também semelhante: $60 \%$ ao México e 54\% ao Brasil. Finalmente, o estoque de investimentos norte-americanos era maior no Brasil do que no México (Wellons, 1987, pp. 236-237). Mesmo assim, o montante da ajuda bilateral para o Brasil foi de apenas 32,5\% da ajuda concedida ao México e ela só foi oferecida depois que o presidente Figueiredo conversou pessoalmente com o secretário de Estado. Ademais, a primeira parcela do empréstimo dos Estados Unidos demorou quase um mês para ser liberada, enquanto as reservas cambiais do Brasil eram perigosamente erodidas.

Segundo Wellons, "as diferenças [entre México e Brasil] para o sistema financeiro norte-americano não são suficientes para justificar uma resposta substancialmente diferente por parte do governo dos EUA" (1987, p. 237). As principais diferenças eram de natureza política e comercial. Parte muito maior das exportações norte-americanas tinham como destino o México do que o Brasil. Ademais, um colapso econômico do México teria impactos muito mais fortes para os EUA em áreas como segurança interna e imigração do que um colapso do Brasil. Como afirma Wellons, os "interesses norte-americanos — segurança, comércio, até mesmo cultura - estão fora do sistema financeiro", mas eles "explicam as diferenças no tratamento dos dois maiores países devedores, cujos defaults ameaçavam o sistema financeiro dos EUA igualmente" (1987, p. 238).

É verdade que as autoridades brasileiras queriam diferenciar-se do México e evitaram admitir a crise no balanço de pagamento porque temiam uma derrota nas eleições de 15 de novembro. Como afirmou um negociador brasileiro, "pedimos sigilo porque poderiam achar que era uma prova de debilidade" (Veja, 1982b, p. 33). Mas isto não é suficiente para explicar a diferença entre os pacotes concedidos ao México e ao Brasil. Um pacote maior e mais rápido do que o obtido pelo governo brasileiro poderia também ter sido mantido em sigilo. A questão é que o volume menor de recursos e os prazos mais lentos de negociação e liberação dos pacotes de auxílio bilateral indicam que havia interesses, oriundos da política doméstica norte-americana, que facilitavam um acordo com o México, mas não com o Brasil.

Em outros termos, é possível aventar a hipótese de que o nível doméstico norteamericano impunha limites diferentes aos níveis de ajuda que o governo do país poderia conceder ao México e ao Brasil. O Tesouro e o Fed fizeram mais concessões ao México do que ao Brasil porque entendiam que o Congresso, refletindo a composição de interesses 
políticos domésticos, seria mais simpático à atuação em favor do vizinho do que de países mais distantes.

As discussões ocorridas no âmbito do FOMC parecem corroborar esta hipótese. Na reunião de 24 de agosto, na qual se tratou do México, os participantes discutiram as condições para o uso de fundos do ESF na operação de salvamento. Anthony Solomon afirma não esperar questionamentos do Congresso quanto à operação. Volcker parece concordar:

VICE CHAIRMAN SOLOMON. Eu diria que haveria apoio muito forte do Congresso. A idéia de caos econômico no México, com todos aqueles milhões de pessoas tentando cruzar a fronteira, causa tanta ansiedade nos congressistas que eu acho que haveria amplo apoio.

SR. MARTIN. O mês seguinte ao da aprovação da primeira grande mudança no estatuto de imigração em 30 ou sei lá quantos anos!

SR. PARTEE. Bem, é claro que provavelmente haverá tanta privação econômica no México que haverá fuga pela fronteira de qualquer jeito.

CHAIRMAN VOLCKER. Sim, vamos ter isso de qualquer modo ${ }^{\text {vii }}$. (FOMC, 1982a, p. 10.)

Pouco mais de um mês depois, a crise já tinha atingido os outros países devedores. Polônia e Argentina já estavam em crise, e o Brasil batia às portas do Fed e do Tesouro pedindo ajuda. Na reunião do FOMC de 5 de outubro, a apresentação de Volcker ganhou um tom pessimista:

Quando se olha para os outros lugares na América Latina, de um lado temos a Argentina, a qual está basicamente incapacitada de se financiar nos mercados e acumula atrasos substanciais no serviço de sua dívida. As autoridades financeiras lá estão dispostos a ir ao Fundo Monetário Internacional. Negociações com o Fundo estão começando sem que saiba se a Argentina tem um governo com força suficiente para assinar um acordo razoável com o Fundo, mesmo que eles o queiram. [...] Esta é um situação que num certo sentido não parece inadministrável economicamente, mas há a questão de quão politicamente administrável ela é. Quando se sobe no continente, há o Equador, o qual poderá se ver incapaz de manter o serviço de sua dívida dentro de poucas semanas. Temos o Chile, o qual, até onde posso ver, está incapacitado de obter empréstimos neste momento e está rapidamente exaurindo suas reservas; e à taxa de consumo das reservas pode-se talvez estimar que talvez encontrem dificuldades com o serviço da sua dívida em uma questão de meses, se não semanas. Temos a Bolívia, a qual tem tido problemas crônicos há anos e não está melhor: está basicamente em moratória. A Costa Rica está na mesma posição. O Peru não está muito diferente. E então chegamos aos países fortes do continente, como o Brasil! Este é outro devedor de US\$ 80 bilhões, o qual em minha visão realizou um forte programa de ajuste nos últimos 18 meses, teve uma recessão, teve contenção monetária, e tentou colocar seu orçamento no lugar. Seu déficit de balança de pagamentos é tão grande hoje quanto era quando eles começaram o programa, refletindo em medida considerável o azedume da economia mundial. Então, é claro, temos a Venezuela, o primeiro país do continente em termos de força financeira. Trata-se de um país relativamente pequeno com grandes reservas de petróleo, mas também encontra-se aparentemente incapaz de se financiar livremente no mercado, [a despeito] de possuir reservas mais substanciais. [...] Esses países possuem uma dívida total de [...] cerca de US\$ 300 bilhões [...], uma grande parte da qual é devida a bancos norte-americanos. Mas todo grande banco ao redor do mundo está mais ou menos igualmente comprometido. Todos esses países dependem de 
financiamento continuado simplesmente para manter as dívidas que eles já possuem aparentemente em ordem ${ }^{\text {viii }}$. (FOMC, 1982b, p. 16.)

A crise, Volcker sabia, representava um risco claro para o sistema bancário:

Tudo isso me traz ao sistema bancário. Nós tivemos alguns problemas bem conhecidos com algumas instituições individuais, cuja origem esteve principalmente nos problemas domésticos dos Estados Unidos. Estas instituições particulares tiveram problemas de financiamento no mercado por algum tempo. Elas basicamente não conseguem ou não querem vender uma quantidade substancial de certificados de depósitos domésticos e estão tendo suas linhas com outros bancos cortadas no mercado diário. Há preocupação, obviamente, [...] com os bancos que possuem grande exposição externa. E quando falamos de bancos com grandes exposições externas não há exceções entre os principais bancos norte-americanos ou entre grande parte dos bancos regionais. [...] É bastante visível que o mercado de eurodólares está em um estado de confusão e preocupação. Pode-se verificar isso especificamente com o fato de que a margem dos juros dos eurodólares sobre os juros domésticos não é explicável apenas pelos cálculos normais de arbitragem entre as duas taxas de juros. [...] [Há] um sentimento de contração do crédito ${ }^{\text {ix. }}$ (FOMC, 1982b, p. 17, grifo meu.)

A despeito de os problemas e os riscos serem maiores e mais evidentes do que pouco mais de um mês antes, Volcker agora antecipava uma grande dificuldade política para as iniciativas que visassem a administrar a crise de forma coordenada:

Nenhum banco central quer tratar essas situações como se fosse uma operação tradicional de banco central. Todos eles teriam a mesma reação que nós provavelmente teríamos: isso é um problema do governo. E alguns deles têm instituições para [resolver isso] e outros não têm. Em virtualmente todos os casos, o banco central tem mais flexibilidade no curto prazo do que o governo; alguns governos não têm nenhuma. Nós temos esse tipo de problema, claro. O próprio governo dos EUA é como se fossem quatro países diferentes! Mas você multiplica isso e a dificuldade se torna geométrica ${ }^{\mathrm{x}}$. (FOMC, 1982b, p. 21.)

À medida que a crise atingia novos países devedores, as soluções que dependiam exclusivamente do governo dos EUA esgotavam-se rapidamente. Havia limites ao uso do ESF e o Fed tinha acordos de swap cambial apenas com o México. Outras agências, como Eximbank e Commodity Credit Corporation, também tinham orçamentos limitados. Quanto à USAID, o Tesouro preferiria não envolvê-la no problema. Para continuar a montar pacotes de auxílio bilaterais em volume suficiente, o governo dos EUA teria de obter aprovação orçamentária do Congresso. Em vez disso, preferiu lançar mão de uma solução multilateral.

O FMI apresentou-se como candidato natural a um papel central: além de já dispor de capital, o Fundo poderia extrair concessões dos países em desenvolvimento, por meio de reformas econômicas, que iam ao encontro dos interesses do governo norte-americano. Ademais, a organização era historicamente ligada ao Tesouro. A próxima seção trata do processo pelo qual o FMI tornou-se o gerente da crise. 


\subsection{A RESPOSTA MULTILATERAL: O FMI E A CONFERÊNCIA DE TORONTO}

À medida que a crise financeira se espalhava e intensificava, aumentavam as dificuldades institucionais e políticas para soluções exclusivamente norte-americanas. Ao mesmo tempo, entre o final de agosto e meados de dezembro, montou-se uma estratégia que, ao delegar ao FMI o gerenciamento da crise, permitiu que os grandes bancos reduzissem gradativamente sua exposição internacional. O processo, embora delegado ao FMI, permaneceu sob controle das autoridades financeiras norte-americanas.

\subsubsection{A DESCONFIANÇA DO GOVERNO REAGAN COM RELAÇÃO AO FMI}

A posse do presidente Ronald Reagan marcou o início de um período de tensão entre o governo norte-americano e as instituições financeiras multilaterais, particularmente o FMI. Muitos integrantes do governo Reagan nutriam verdadeira desconfiança com relação ao Fundo. Por um lado, julgavam que sua função seria apenas atender às necessidades do "Quarto Mundo", os países de menor desenvolvimento relativo, que não contavam com acesso regular ao mercado financeiro internacional, enquanto os países de renda média teriam suas demandas de financiamento adequadamente supridas pelos bancos comerciais (Batista Jr., 1988, p. 215). Por outro lado, os conservadores que chegaram ao poder com Reagan estavam certos de que os organismos internacionais eram pouco mais que órgãos políticos que serviam para emprestar recursos dos EUA para países que não compartilhavam com os norteamericanos seu entusiasmo pelo livre mercado. A escolha de David Stockman, um supplysider e crítico ferrenho do Fundo, para chefiar o Escritório de Administração e Orçamento (OMB) prenunciou dificuldades para qualquer iniciativa de aumentar o capital daquela organização. Um exemplo da visão conservadora foi oferecido pelo ex-secretário do Tesouro William Simon:

Quando concordamos em contribuir com o caixa do FMI, nós transferimos nossos recursos para uma organização supranacional que nós não controlamos, para serem desembolsados por uma burocracia internacional. A abordagem multilateral tem a vantagem de arrastar outros para o processo de ajuda, e os EUA não são deixados sozinhos segurando a sacola, mas as desvantagens são grandes. É difícil manter os intermediários multilaterais sob controle, e nós acabamos nos habituando a subsidiar todo governo socialista no Terceiro $\operatorname{Mundo}^{\mathrm{xi}}$ (Simon, 1983).

Na mesma linha, o ex-secretário-assistente do Tesouro Paul Craig Roberts afirmou que

Passar ajuda internacional por meio de uma burocracia internacional reduz o controle e a influência dos países doadores. O resultado final é divorciar a política externa dos interesses políticos dos Estados Unidos e da aliança da OTAN. Quando deixamos que o 
FMI desembolse nosso dinheiro por nós, não podemos extrair benefícios políticos e estratégicos dos países recebedores na base do toma-lá-dá-cáxii. (U.S. Senate, 1983b, p. 65).

Na conferência conjunta do FMI e do Banco Mundial de setembro de 1981, o próprio presidente Reagan deixou clara sua visão para o papel das instituições financeiras multilaterais. Segundo Reagan, "nenhuma quantidade de ajuda vai produzir progresso" a não ser que os países subdesenvolvidos resolvam seus problemas econômicos e financeiros, incentivem a livre iniciativa e permitam que a "mágica do mercado" os leve ao desenvolvimento (Farnsworth, 1981b).

Um dos maiores motivos de conflito entre o governo Reagan e o FMI era relativo às condicionalidades, ou seja, aos ajustes econômicos exigidos pelo Fundo como condição para liberar seus empréstimos. A partir de 1979, a entidade começou a tornar mais flexíveis suas exigências, e revisou sua política de condicionalidades de maneira a levar em conta o caráter estrutural dos desequilíbrios em balança de pagamentos de muitos países. Nesse sentido, o período dos programas de ajustamento foi alongado de 12 para 36 meses (Cohen, 1985, pp. 720-721), e um documento oficial do FMI de 1980 afirmava que "a condicionalidade deve ser adaptada às circunstâncias cambiantes e aos casos específicos; não pode ser uma lista rígida e inflexível de regras operacionais" (apud Francis, 1981). Para o novo governo norteamericano, estas mudanças nas exigências para concessão de empréstimos eram contrárias à função do FMI, que seria apenas o de fornecer assistência de curto prazo para países em dificuldades temporárias de balança de pagamentos. Segundo o então vice-presidente do Citibank, George Clark, "quando a nova administração assumiu [...] o Fundo passava por uma fase do que chamamos de 'condicionalidade fraca'. A administração estava preocupada naquela época, e eu acho que eles estavam certos em estar preocupados. Mas graças aos esforços da administração e de outros, incluindo os bancos comerciais, nós dissemos ao Fundo que tínhamos de ter condicionalidade estrita" (U.S. Senate, 1982, p. 20). A partir do segundo semestre de 1981, em função da pressão das autoridades dos EUA, a flexibilização das condicionalidades foi revertida. Em seu lugar, voltaram as condicionalidades estritas, voltadas a criar um ambiente de "liberdade econômica", como caracterizado pelo presidente Reagan (Farnsworth, 1981b).

Esta mesma visão levou o governo americano a desencorajar qualquer tentativa de antecipar a oitava revisão das quotas e do capital do Fundo, que estava marcada para começar em 1984. No primeiro semestre de 1981, de Larosière já havia defendido o aumento do capital da instituição, à luz do aumento das taxas de juros e da conseqüente redução dos 
créditos privados e do aumento da demanda por recursos oficiais por parte dos países em desenvolvimento. No entanto, à época, o secretário do Tesouro Regan foi indiferente (Parola, 1991, pp. 49-50). Por um lado, o governo mostrava-se preocupado com o impacto dos programas de ajuda internacional sobre os gastos públicos. Por outro lado, coerente com a ideologia conservadora que o levara à presidência, Reagan temia que instituições financeiras multilaterais muito fortes substituíssem os bancos comerciais como principais financiadores dos países em desenvolvimento e permitissem a estes países empreender políticas consideradas pouco ortodoxas (Rowen, 1981c).

A crise mexicana mudaria a percepção do governo sobre a utilidade do FMI. Como veremos, a partir da Conferência de Toronto o governo começou a ver no Fundo uma instância de gerenciamento de longo prazo da crise financeira, que poderia ser usada para promover interesses norte-americanos.

\subsubsection{A CONFERÊNCIA DE TORONTO}

Entre os dias 6 e 9 de setembro, ocorreria em Toronto a conferência anual do FMI e do Banco Mundial. Esta reunião geralmente é um encontro da comunidade financeira internacional, no qual as discussões - sempre realizadas com discrição — eram talvez menos importantes do que as oportunidades para seus membros estabelecerem contatos e ampliarem suas redes de relacionamento. Mas, neste ano, o caráter social do encontro ficaria em segundo plano, pois nele seriam discutidas possíveis respostas à crise financeira.

O clima era de pessimismo com relação ao crédito privado. Muitos analistas afirmavam que o FMI e o Banco Mundial teriam de substituir os bancos no papel de financiadores dos países em desenvolvimento. À medida que a reunião se aproximava, governos e analistas se dividiram em dois grupos. Os países europeus e latino-americanos, bem como a própria gerência do FMI, queriam um grande aumento do capital da organização, de maneira a permitir que os países devedores compensassem a redução do crédito privado com créditos oficiais do Fundo. A idéia circulada pelo FMI era de aumentar seu capital de cerca de US\$ 67 bilhões para, no mínimo, US\$ 110 bilhões, podendo chegar até a US\$ 137 bilhões.

Os EUA, no entanto, resistiam à idéia, alegando que seria "desnecessária" a ampliação do capital do Fundo e que o Congresso não aprovaria o aumento de US\$ 14 bilhões na quota norte-americana que ela implicaria (Rowen, 1982c). 
A idéia dos países europeus e do Terceiro Mundo não era apenas aumentar o capital do FMI, mas sim mudar sua forma de atuação. Como afirma Batista Jr., “o FMI foi concebido para lidar com problemas de balanço de pagamentos de países individuais em dificuldades presumivelmente temporárias de balanço de pagamentos" (1988, p. 216), e por isso sua "receita" de ajustamento macroeconômico implicava em retração da demanda interna e geração de superávits comerciais. A receita poderia funcionar em casos individuais, mas é contraproducente numa situação de crise que afeta um grande número de países ao mesmo tempo, pois os obriga a retrair sua demanda e suas importações ao mesmo tempo. Por isso, o que se propunha era usar o FMI como forma de manter o financiamento aos países em desenvolvimento nos níveis similares aos vigentes antes da crise, de forma a evitar uma retração muito grande nos fluxos de comércio. Como admitiu C. Fred Bergsten, o pressuposto que fundamentava esta posição era que "uma fatia menor dos déficits dos países em desenvolvimento será financiada por empréstimos privados", o que implica em que "a única forma de compensar esta redução [nos empréstimos privados] é um aumento do lado público" (U.S. Senate, 1982, p. 25).

Usar o FMI para compensar a redução da oferta de fundos privados exigiria uma mudança no processo de concessão de empréstimos, de modo a reduzir a quantidade de exigências (as "condicionalidades"). Isto era contrário às preferências do governo Reagan, preocupado em não aumentar de tal forma o capital do Fundo a ponto de permitir-lhe relaxar as condicionalidades. Como afirmou McNamar perante o Congresso, "não queremos prover fundos que criem um viés favorável a expansão excessiva” (U.S. Senate, 1982, p. 51).

A posição dos países latino-americanos parece coerente com o argumento de que a intervenção do FMI seria vista positivamente pelos governos destes países, e aumentaria sua capacidade de realizar ajustes macroeconômicos difíceis. Por outro lado, ao favorecerem um grande aumento do capital do Fundo, os países devedores também pareciam indicar a expectativa de que, quanto mais capital estivesse disponível para a instituição, menos rígidas seriam as condicionalidades que ela exigiria para conceder novos empréstimos.

A posição dos países europeus e do Japão, por outro lado, não se mostra coerente com o argumento de que o FMI seria principalmente uma forma de o hegemon do sistema extrair contribuições dos outros países desenvolvidos para prover a estabilidade do sistema internacional. Se os outros países desenvolvidos vissem o FMI dessa forma, eles assumiriam uma posição mais cautelosa e não proporiam um aumento maior do que o próprio hegemon 
parecia disposto a aceitar. Ao contrário, é possível, a partir do comportamento dos governos destes países, se aventar a hipótese de que eles na verdade viam um grande aumento de capital do FMI como uma forma de garantir o comprometimento do próprio hegemon, que naquele momento dava sinais de relutância.

Os principais bancos, por seu turno, vendo no financiamento oficial via FMI uma forma de reduzirem rapidamente sua exposição aos países devedores, tentaram promover uma proposta maximalista. Além de defenderem um grande aumento das quotas do Fundo, propunham que a instituição fosse autorizada pelo Conselho Executivo a tomar empréstimos no mercado privado, a exemplo do que fazia o Banco Mundial. Isto seria uma forma de aumentar rapidamente os recursos disponíveis pelo FMI sem necessidade de aprovação legislativa por parte dos Estados-membros. Este argumento ficaria claro no depoimento de George J. Clark, vice-presidente executivo do Citibank, perante a Câmara de Deputados em setembro de 1982:

Creio que o processo de ir aos congressos e parlamentos do mundo para pedir os aumentos das quotas poderá levar muito tempo. Eu instaria sua comissão, Sr. Presidente, a considerar a possibilidade de um método diferente e talvez mais rápido.

Trata-se de alterar as políticas atuais do FMI, e isto pode ser feito no nível do conselho de diretores com a participação do diretor executivo dos Estados Unidos, de maneira a [...] permitir programas especiais não vinculados aos montantes das quotas [dos paísesmembros] no FMI. Seriam programas específicos para servir de rede de proteção.

[...] Eu sugeriria que o Fundo Monetário Internacional seja autorizado pela primeira vez a voltar-se aos mercados de capitais privados do mundo [...]. [Esta política] não implica em que se retorne aos países-membros para se obter novas autorizações ${ }^{\text {xiii. }}$ (U.S. Senate, 1982, p. 11, grifo meu.)

Note-se que a proposta, além de contornar os legislativos dos Estados-membros, permitiria que um país tomasse emprestado um volume de recursos muito maior do que o permitido pela sua quota no FMI. A proposta representava um bailout evidente. Na prática, os bancos continuariam a emprestar aos países em desenvolvimento - assim, quem quisesse não precisaria abandonar o lucrativo mercado internacional - mas usariam o Fundo como intermediário e assim correriam muito menos riscos na operação, já que prejuízos causados por eventuais atrasos ou defaults seriam incorridos pela instituição multilateral.

Os dias que antecederam a conferência assistiram a uma erosão da confiança dos agentes econômicos. No dia 20 de agosto, rumores de que o sistema financeiro estaria em risco causou uma "corrida para a segurança", ou seja, uma redução da demanda por certificados de depósito e um aumento da demanda por títulos do Tesouro. Como afirmou um 
banqueiro novaiorquino, "o mercado está extremamente preocupado com a qualidade e a saúde do sistema financeiro" (Foldessy, 1982).

No dia 24 de agosto, o Institute for International Economics divulgou um estudo, elaborado por John Williamson, que afirmava que o FMI não teria fundos suficientes para montar outro pacote como o que estava sendo negociado com o México. Como se esperava que outros devedores em breve enfrentassem dificuldades para se financiar com os bancos privados, o estudo indicava que seria preciso dobrar o capital do Fundo (Rowen, 1982a). No dia seguinte, o subsecretário do Tesouro Beryl Sprinkel questionaria veementemente os resultados do estudo, afirmando que eles subestimavam os recursos à disposição do FMI. Sprinkel também negou que o governo norte-americano estivesse considerando aumentar o capital do FMI, pois, além de avaliar que não conseguiria a aprovação do Congresso, não acreditava "que isso [fosse] necessário" (Rowen, 1982b). Em oposição ao aumento de capital, o governo norte-americano circulava a idéia de criar um "fundo de crise" de US\$ 25 bilhões, financiado pelos países industrializados, que entraria em ação em casos como o do México (Pine, 1982a, Rowen, 1982e).

No dia 27 de agosto, o Chase Manhattan - que vinha de grandes perdas no mercado norte-americano e estava altamente exposto aos outros países da América Latina, detendo, apenas em recebíveis de curto prazo do México, US\$ 1,75 bilhão — teve seus certificados de depósito removidos da lista dos títulos aceitos pela Bolsa de Mercadorias de Chicago como margem em operações de contratos futuros. O delisting do Chase Manhattan sublinhou as dificuldades do sistema financeiro e os riscos da crise financeira (Business Week, 1982).

As sucessivas más notícias aumentavam o pessimismo. No dia 31 de agosto, o governo argentino confirmou os temores de que não conseguiria cumprir com todos os seus compromissos financeiros de 1982. O país já tinha acumulado mais de US\$ 2 bilhões em atrasos e negociava com o Reino Unido o fim das sanções recíprocas que haviam sido impostas por ocasião da Guerra das Malvinas e que impediam a Argentina de pagar juros a bancos ingleses (Atkinson e Rowe, 1982a). No dia $1^{\circ}$ de setembro, enquanto Silva Herzog e sua equipe trabalhavam para preparar uma Carta de Intenções com o FMI, o presidente do México, López Portillo, subitamente anunciou a nacionalização de todos os bancos privados e a imposição de controles cambiais. A decisão, que surpreendeu o governo norte-americano e os banqueiros, foi atribuída ao risco de que os próprios bancos mexicanos pudessem falir por causa da enorme desvalorização da moeda mexicana (Atkinson e Rowe, 1982b) e descarrilou 
as negociações em andamento com o FMI. No dia seguinte, Silva Herzog e o presidente do banco central mexicano, Manuel Mancera Aguayo, pediram demissão por discordar das medidas, enquanto uma manifestação de apoio a elas reunia 500 mil pessoas na Cidade do México. López Portillo aceitou o pedido de demissão de Mancera e substituíu-o por Carlos Tello, um importante economista da linha estruturalista, mas manteve Silva Herzog no cargo de ministro da Fazenda (Kraft, 1984, p 39, Boughton, 2001, p. 300).

No dia seguinte, rumores de que a Argentina estava a ponto de declarar moratória causaram um aumento de $8 \%$ no preço do ouro em apenas um dia (Wall Street Journal, 1982). De fato, como reflexo do temor de que a crise pudesse se espalhar e comprometer o sistema bancário norte-americano, o preço do ouro aumentara quase 17\% desde 20 de agosto. (Mackay-Smith e Grover, 1982).

No dia 3 de setembro, os ministros da Fazenda do grupo dos principais países em desenvolvimento (o G-24) se reuniram em Toronto, em encontro preliminar ao do FMI e BIRD, e emitiram uma declaração que avisava que "a menos que as tendências adversas na economia internacional sejam revertidas, todo o sistema internacional de comércio e finanças pode ruir". No encontro, os representantes dos países do G-24 defenderam um grande aumento nas quotas do Fundo, e descartaram a idéia norte-americana de um "fundo de crise" (Rowen, 1982e) ${ }^{59}$. O "fundo de crise" foi rejeitado em definitivo na reunião do Comitê Interino do FMI, no dia 5. Ao final desta reunião, tentou-se emitir uma declaração que afirmava haver "amplo apoio" para um aumento nas quotas do Fundo, mas o secretário do Tesouro recusou-se a assiná-la. Isto deixou evidente a falta de consenso entre os principais países industrializados (Rowen, 1982d).

$\mathrm{Na}$ abertura da conferência, Donald Regan frustrou quem esperava uma solução rápida por parte dos EUA. "As outras nações têm que entender que mesmo os EUA têm suas limitações", afirmou Regan em seu pronunciamento. "Não podemos fazer tudo. Não podemos ser o defensor do mundo ocidental [...], e ter grandes gastos com defesa, e ao mesmo tempo gerir os mesmos programas sociais que vimos gerindo e dar tanta ajuda externa como temos dado", declarou, associando a indisposição de seu governo a aumentar as contribuições às instituições financeiras multilaterais com a necessidade de reduzir o déficit público norte-

\footnotetext{
${ }^{59}$ Segundo Boughton (2001, pp. 300-301), Tim McNamar encontrou-se com De Larosière e Ted Beza, negociador-chefe do FMI para o México, na noite do próprio dia 3 e insistiu em que o Fundo anunciasse um empréstimo ao México imediatamente. Boughton não oferece referências para lastrear esta afirmação, e eu tampouco consegui encontrar qualquer outra referência a este encontro.
} 
americano, objeto de intensas disputas no Congresso (Farnsworth, 1982d, May, 1982, Associated Press, 1982).

No dia 7, o pessimismo, as medidas tomadas por Lopez Portillo e a indisposição norteamericana em arrumar uma solução rápida para salvar os bancos que emprestaram ao México causaram um pânico no mercado interbancário. Durante todo o dia, as agências dos bancos mexicanos em Nova York foram inundadas por pedidos de retirada de depósitos. A crise foi evitada com a intervenção pessoal de Volcker, que adiantou US\$ 70 milhões da linha de crédito do BIS para zerar as posições dos bancos mexicanos no final do dia (Kraft, 1984, pp. 40-41, Boughton, 2001, p. 301).

Durante a conferência em Toronto, a delegação dos EUA viu-se isolada, mas pouco cedeu. Revertendo a posição original de que nenhum aumento das quotas seria possível ou desejável, os norte-americanos admitiram iniciar negociações com vistas a um aumento da capitalização do FMI. Recusaram-se, porém, a aceitar o percentual proposto pelos europeus e, alegando que um excesso de crédito poderia causar uma espiral inflacionária, mostraram-se dispostos a um aumento de no máximo 15\% (Rowen, 1982i). A delegação norte-americana também condicionou este aumento à manutenção das exigências tradicionais de ajuste macroeconômico por parte dos países devedores. Sobre este último ponto, Beryl Sprinkel afirmou que "o Fundo fez muitos progressos no sentido de encorajar condicionalidades mais estritas. Não queremos ver isso desfeito" (Farnsworth, 1982e).

Ademais, durante toda a conferência os norte-americanos afirmaram temer que o Congresso não aprovasse um aumento muito grande da quota norte-americana, pois as diversas disputas orçamentárias que haviam sido travadas desde o início do governo Reagan tinham tornado difícil obter aprovação de quaisquer medidas que pudessem ser vistas como ajuda internacional. Como afirmou um funcionário do governo, "nós temos um problema político terrível” (Farnsworth, 1982c). Segundo Sprinkel, "quando o exercício começou, muitos países estavam propondo 200 porcento, muitos 150 porcento, muitos 100 porcento de aumento das quotas. Nós não apenas não acreditamos que isso não seja possível, nós temos que ser realistas sobre o que pedimos ao Congresso" (Farnsworth, 1982e). Por fim, a delegação norte-americana garantiu não abandonar a idéia do "fundo de crise" (Rowen, 1982g, 1982h).

A decepção com a falta de resultados da conferência contribuiu para aumentar o clima de pessimismo no mercado financeiro. "Oportunidade perdida em Toronto", decretou a 
manchete do Washington Post. "Os grandes banqueiros e suas contrapartes nos governos e nas agências internacionais de financiamento estão [em Toronto], e eles parecem ter perdido uma chance de aumentar a confiança em um sistema econômico frágil” (Rowen, 1982f). Na mesma linha, o Globe and Mail, principal jornal canadense, afirmou em artigo publicado no dia 10 que

Os gnomos da finança global fecharam suas pastas executivas e deixaram Toronto, mal tendo arranhado a montanha de problemas econômicos que projetou sua sombra sobre as deliberações do Fundo Monetário Internacional e do Banco Mundial. Alguém realmente esperava algo mais? [...]

Contudo, a objeção dos EUA bloqueou um aumento substancial do capital do FMI, e sua contra-proposta de um fundo de emergência para salvar os quase falidos foi vaga e teria pouca probabilidade de ser implementada a tempo de ter qualquer utilidade. Então os bancos continuam sem uma rede de proteção (Globe and Mail, 1982).

O pessimismo com a possibilidade de uma crise global seria resumido por Denis Healey, ex-chanceler do Exchequer britânico: "o risco de que um grande default inicie uma reação em cadeia cresce a cada dia" (Pine, 1982b).

\subsubsection{A CRISE CHEGA AO CONGRESSO}

Depois da reunião de Toronto, a crise da dívida chegaria rapidamente ao Congresso dos Estados Unidos, que retornava do recesso de verão. A crise mexicana foi objeto de diversos pronunciamentos, de uma proposta de resolução da Câmara dos Deputados e de uma carta aberta ao presidente Reagan. Os congressistas mostravam-se dispostos a questionar e, se possível, influir nas decisões tomadas pelo Tesouro e pelo Federal Reserve com relação ao México. Um dos resultados mais palpáveis da atenção dispensada pelo Congresso ao tema foi o início do movimento que propunha fortalecer a supervisão bancária, cujas falhas em regular as operações internacionais começavam a ser apontadas como uma das causas da crise.

No dia 13 de setembro, a Subcomissão de Supervisão da Comissão de Energia e Comércio da Câmara dos Deputados iniciou uma investigação sobre práticas contábeis do Citibank em suas operações européias. Durante três anos, a Securities and Exchange Commission (SEC) investigara transações fantasmas realizadas pelo banco entre 1973 e 1980 que visavam a burlar limites impostos pela legislação e transferir, impropriamente, lucros das filiais européias para filiais em paraísos fiscais, para minimizar os impostos. Os deputados se mostraram particularmente preocupados com o fato de que, no final de 1981, a nova administração da SEC, indicada por Reagan, decidira ignorar os resultados da investigação e não punir o Citibank. Os argumentos da SEC para encerrar o caso foram chamados de 
"risíveis" por Stanley Sporkin, que supervisionara a investigação antes de sair da agência. Enquanto os deputados republicanos tentaram defender os dirigentes da SEC, os democratas se mostraram preocupados com o fato de que, "ao rejeitar a recomendação [dos investigadores] para punir o Citibank, a comissão reverteu precedentes há muito estabelecidos e introduziu novos critérios para divulgação de informação", como afirmou o deputado John Dingell (democrata de Michigan), presidente da subcomissão. "O vale-tudo regulatório contribuiu para a grave crise que agora envolve o sistema bancário internacional", alertou Richard Dale, economista da Brookings Institution que defendeu um reforço do sistema de supervisão bancária (Gerth, 1982, Rowe Jr., 1982, Kramer, 1982).

No dia 14 de setembro, o deputado Henry Gonzalez (democrata do Texas) afirmou perante o plenário da Câmara que “a situação [no México] é alarmante” e que seus desdobramentos estavam criando problemas graves para empresas norte-americanas, particularmente perto da fronteira. Pediu a intervenção do Federal Reserve para garantir a conversibilidade do peso e deter sua desvalorização. Por fim, refletindo uma postura tradicional de desconfiança com relação ao setor financeiro, acusou o governo de ignorar os problemas dos outros setores da economia e se preocupar apenas em salvar bancos:

Todos os nossos jornais publicaram artigos sobre a ajuda de emergência que nós, através do Federal Reserve Board, demos ao México. Bem, isto não é correto. Nós não demos nada ao México. O dinheiro que nós fornecemos foi para salvar bancos americanos. Foi alívio, salvamento para os bancos americanos, para os quais o governo não impõe limites. Ele impõe limites às corporações americanas. Eles não querem salvamentos para elas. Eles não querem salvamentos para as pequenas empresas, mas se se tratar de um banco, então US\$ 1 bilhão de um dia para o outro e sem questionamentos foi o que eles arrumaram para salvar bancos como o Chase Manhattan e o Hanover Manufacturers Trust [...]. Os que se dizem mais conservadores são aqueles que foram os piores investidores e gastadores e especuladores, agindo por pura ganância. Ganância é o que está nos afundando ${ }^{\text {xiv }}$. (Gonzales, 1982, pp. 23479-23480).

No dia 15, o senador Jesse Helms (republicano da Carolina do Norte) foi além e apresentou proposta de resolução sobre a crise mexicana que procurava forçar o governo dos EUA a exigir certas medidas por parte do governo do México. O texto proposto proibia o governo norte-americano de oferecer qualquer assistência ao México, a não ser que este se comprometesse a (a) adotar uma política monetária que visasse a estabilizar o valor do peso vis-à-vis o dólar, (b) suspender e eliminar todos os controles de câmbio e de circulação de capital, e (c) restaurar as instituições financeiros nacionalizadas aos seus proprietários originais. Em seu pronunciamento no plenário, Helms afirmou que "a tragédia do atual caos monetário no México é o imenso dano que ele vai causar ao povo do México", e que por isso 
os EUA "têm uma responsabilidade nesta situação, mas minha preocupação é que [a participação americana] vai ser pouco mais do que um salvamento temporário — algo que vai parecer ajudar mais os banqueiros de Wall Street do que os cidadãos mexicanos"xv ${ }^{\text {" Segundo }}$ Helms, "tenho pouca compaixão por banqueiros que emprestaram bilhões de dólares para o México a despeito de saberem perfeitamente que as políticas econômicas do país inexoravelmente levariam à crise" e, portanto, os bancos é que "deveriam arcar com a maior parte das perdas - não o contribuinte americano". Por isso, continou, propôs uma solução para evitar que os recursos norte-americanos fossem utilizados em "esquemas insensatos". "Se seguirmos a prática costumeira de assistência financeira dos EUA, [...] o México receberá um salvamento temporário, apesar de ser provável que uma repetição da débacle financeira atual esteja nos esperando logo ali na esquina”, afirmou. Se o México não adotar as medidas propostas em sua resolução, segundo Helms, o dinheiro dos contribuintes norteamericanos seria desperdiçado e "nós poderíamos igualmente usá-lo para construir um muro de dez metros de altura ao longo de nossa fronteira meridional"xvi , porque a crise econômica do México iria continuar e, com ela, a imigração ilegal em território norte-americano (Helms, 1982, pp. 23635-23636).

No dia 16, o deputado Jim Jeffries (republicano do Kansas) apresentou, em discurso na Câmara, uma carta aberta apócrifa, atribuída a personalidades latinoamericanas, que apontava a existência de uma "máfia comunista" que teria chegado ao poder no México com o presidente Luis Echeverría, cujas políticas "socialistas" teriam causado a crise financeira. A "máfia" teria permanecido no poder sob a presidência de López Portillo. Por isso, continuava a carta, o governo norte-americano deveria condicionar sua assistência ao país ao encerramento do "processo de nacionalização que levará [o México] ao comunismo". Por fim, a carta aberta alertava para que não se deixasse que "banqueiros ou diplomatas" conduzissem as negociações dos EUA com o México: "Banqueiros e diplomatas liberais não devem receber a oportunidade de resolver a situação levando em conta apenas o ponto de vista financeiro, pois eles poderiam ajudar a construir um problema político de gravidade incalculável ao sul da fronteira"xvii (Jeffries, 1982, pp. 24020-24021). O tema da "tendência socializante" que estaria em curso no México seria retomada em outra carta aberta, assinada por 36 deputados conservadores (dos quais 30 republicanos) e endereçada ao presidente Reagan em 29 de setembro. Nesta carta, pedia-se que o governo norte-americano tomasse 
"ações apropriadas" para impedir que o governo do presidente Miguel de la Madrid continuasse com o programa empreendido pelos seus dois antecessores.

No dia 20 de setembro, o senador Bill Bradley (democrata de Nova Jersey) fez longa apresentação sobre o problema da dívida, e propôs a criação de um fundo de emergência, a ser administrado pelo FMI, para evitar a insolvência dos países devedores. Este fundo faria empréstimos de curto prazo sob a condição de que os países beneficiários modificassem as "práticas econômicas" que tinham produzido ou exacerbado seus problemas financeiros uma idéia muito similar à que seria de fato adotada pelo FMI, e que o próprio Bradley, posteriormente, criticaria (Bradley, 1982, p. 24166).

O conjunto dos discursos proferidos e das iniciativas propostas em setembro mostra uma disposição do Congresso de interferir, de alguma forma, no problema da dívida. Também mostra que, para parte importante dos congressistas conservadores, a crise era resultado de empréstimos irresponsáveis realizados pelos bancos ou do nacionalismo econômico (que alguns chegavam a caracterizar como "tendência socializante") do governo mexicano. Por isso, na visão destes congressistas, o "contribuinte norte-americano" (representado pelo Tesouro e pelo Fed) não deveria arcar com os custos da ajuda ao México, já que quem deveria pagar por isso seriam os bancos ou o próprio governo mexicano. Note-se que tais congressistas compunham justamente a principal base política do governo Reagan.

Por fim, no dia 27 de setembro, a Subcomissão da Política Econômica Internacional da Comissão de Relações Exteriores do Senado reuniu-se para "olhar para o sério problema global da dívida internacional", segundo seu presidente, o senador Charles Mathias (U.S. Senate, 1982, p. 1). Uma análise desta audiência nos permite verificar a posição pública de alguns atores - em particular do Tesouro — com relação à questão, naquele momento ${ }^{60}$.

O painel de especialistas era composto por pessoas ligadas ao establishment financeiro: C. Fred Bergstein, do Institute for International Economics, Jeffrey Garten, do banco de investimento Lehman Brothers Kuhn Loeb, e George Clark, vice-presidente executivo do Citibank. Seus depoimentos eram representativos da posição grupo de interesses aos quais estavam ligados, ou seja, o setor financeiro internacional. Os especialistas praticamente repetiram a posição assumida pelos bancos em Toronto, ou seja, de que o FMI deveria ser o principal gerente da crise e que, para realizar tal função, deveria ser

\footnotetext{
${ }^{60}$ Para o texto completo da transcrição, cf. U.S. Senate (1982).
} 
recapitalizado. Para isso, além do aumento de quotas, não poderiam ser descartadas outras medidas, como a autorização para tomada de empréstimos junto aos bancos privados.

Os membros da subcomissão, e em particular seu presidente, mostravam-se receptivos às preocupações dos especialistas, bem como à lógica que orientava seu raciocínio. Isto fica claro não apenas em suas perguntas e intervenções, mas também no fato de que especialistas hostis ao setor bancário não foram sequer convidados à audiência. A postura dos integrantes da subcomissão era coerente com a tradicionalmente maior disposição do Senado em apoiar iniciativas do Poder Executivo em política externa do que a Câmara. Também era coerente com a proposição teórica de que uma comissão parlamentar tende a atrair congressistas fortemente interessados nos temas tratados por ela e, portanto, tenderá a ter uma posição mais próxima da dos principais grupos de interesse ligados a estes temas do que o conjunto do Legislativo (Davidson, 1974, Shepsle, 1978) ${ }^{61}$.

Richard McNamar, vice-secretário do Tesouro, também depôs nesta audiência e apresentou a posição oficial do seu departamento.

Na visão do Tesouro, a crise era passageira: "a situação hoje, embora séria, é gerenciável, parece transitória e, em certo grau, se corrigirá sozinha"xviii (U.S. Senate, 1982, p. 32). Um problema era a concentração dos empréstimos para um pequeno grupo de países exportadores de petróleo ou de produtos manufaturados (p. 36). Mas, mesmo dentro deste grupo de países, alguns se mostravam em boa situação, como o Brasil (p. 40). McNamar também reconhecia que processos domésticos norte-americanos tinham causado o problema, pois, segundo ele, grande parte do "nervosismo" dos mercados financeiros devia-se à "incerteza causada domesticamente por mudanças estruturais em nossos mercados monetários", onde os bancos dependem, para se financiar, de depositantes norte-americanos (p. 40). No plano internacional, era encorajador verificar que um número crescente de países aceitava a necessidade de programas macroeconômicos "sérios, até drásticos" para ajustar suas economias às novas condições do mercado (p. 41). Desta forma, não havia motivo para pânico: como afirmou McNamar, "nós não encaramos a situação como uma crise real ou iminente" (p. 38). Ao contrário: segundo os estudos do Tesouro, "o grau de risco ao sistema financeiro e ao crescimento econômico global tem sido exagerado na imprensa e em outros lugares" (p. 44).

\footnotetext{
${ }^{61}$ Segundo Davidson, "não é segredo que comissões tendem a atrair membros intimamente preocupados com os temas delas - às vezes a ponto de incorrerem em sérios conflitos de interesse. As comissões, por seu turno,
} 
Como forma de manter a estabilidade financeira, era necessário "afetar o ajustamento econômico e promover políticas dentro de cada país que sejam consistentes com a ordem econômica internacional" (ibidem, p. 50). Para realizar este objetivo de mudar a política econômica dos países devedores, McNamar defendia a abordagem multilateral, em oposição a uma solução bilateral. Em particular, deveriam ser evitadas soluções baseadas em ajuda bilateral da USAID, pois, segundo McNamar, quando se avalia os diversos projetos de ajuda, "o desembolso de ajuda econômica bilateral foi geralmente acompanhado de ajuste econômico inadequado" (p. 50). Uma razão disto era o fato de que "ajuda bilateral pode ser concedida por outros propósitos políticos", não apenas com vistas a permitir que os países que a recebem ajustem suas economias (ibidem). Em grande medida, os problemas da abordagem bilateral deviam-se também à instabilidade política norte-americana: às vezes um projeto era assinado pelo Executivo mas vetado pelo Congresso, ou, aprovado por este, era interrompido por causa de uma mudança no Executivo (pp. 50-51). Por estas razões, o Tesouro preferia lançar mão da "forte estrutura multilateral" já existente.

Os componentes desta abordagem multilateral seriam o FMI, os bancos centrais, o BIS e os bancos multilaterais de desenvolvimento (o Banco Mundial e os bancos regionais, como o BID). Um conjunto de grupos consultivos, liderados pelo Banco Mundial, serviria para organizar, racionalizar e aumentar o fluxo de recursos financeiros no âmbito de programas bilaterais de ajuda internacional. O Clube de Paris e o Clube de Londres reescalonariam as dívidas oficiais dos países em crise. Finalmente, a última perna da abordagem seria um fortalecimento da regulação bancária, de forma a assegurar que as operações do setor financeiro seriam conduzidas com "prudência e propriedade" (ibidem, pp. 42-43).

O governo se mostrava favorável a um aumento do capital do FMI, mas ainda não tinha definido qual seria o percentual mais adequado, nem a forma de fazê-lo. Segundo McNamar, duas considerações estavam sendo levadas em conta: primeiro, que o Fundo obtivesse os capitais necessários para fazer "o que quer que tenha que fazer"; segundo, que não tenha recursos demais, que poderiam levar "o staff ou o Conselho a reduzir sua insistência em políticas de ajustamento", pois "toda organização [...] tem a tendência a gastar o que lhe é dado", e por isso o Tesouro preocupava-se em não "prover fundos que criariam um viés para a expansão excessiva" (p. 51). Por esta mesma razão, o governo via com ressalvas a idéia de 
permitir que o Fundo se financiasse diretamente junto a bancos privados, pois não queria que o FMI tivesse dinheiro demais.

Do lado da política doméstica, McNamar enumerou as principais medidas que o governo norte-americano tomaria. Primeiro, manteria seus mercados abertos e prestaria apoio ao GATT, como forma de evitar um recrudescimento do protecionismo. Segundo, manteria sua "vigorosa busca do crescimento econômico não-inflacionário", o que significava que os juros não seriam reduzidos na velocidade que alguns atores, particularmente os países devedores, gostariam. Terceiro, reiteraria seu apoio às instituições internacionais, "em particular o FMI”. Quarto, a despeito de fortalecer a regulação bancária, os EUA não ditariam aos bancos "para quem eles devem emprestar ou não", pois o governo acreditava que a liberdade de mercado era a melhor forma de garantir sua eficiência. Quinto, o governo norteamericano continuaria a monitorar a situação de perto e a coordenar-se com outros países e com organismos multilaterais (ibidem, p. 45).

Finalmente, McNamar afirmou que, embora ainda não tivesse uma proposta fechada para o aumento de capital do FMI, o governo começava a conversar desde logo com o Congresso para evitar uma situação na qual algum montante fosse acordado com os outros Estados-membros da instituição mas o Legislativo, posteriormente, rejeitasse o aumento. Assim, mais uma vez, o subsecretário do Tesouro evidenciava sua preocupação com relação ao apoio do Congresso para a proposta de ampliação do capital do Fundo, antecipando uma luta mais difícil na Câmara e no plenário do Senado do que o clima cordial das discussões na subcomissão do Senado poderia indicar.

A partir do depoimento de McNamar, é possível depreender que, neste momento, o Tesouro já tinha algumas posições bem definidas: (i) a crise financeira seria “internacionalizada", ou seja, tratada como um problema de política externa; mas, a despeito disto, (ii) o Departamento de Estado não teria papel relevante em sua solução e (iii) o governo admitia que algumas mudanças na legislação bancária do país seriam necessárias, procurando, desta forma, manter a iniciativa política também sobre esse aspecto do problema. Outras questões ainda pareciam em aberto, das quais as mais importantes eram (i) quais organizações internacionais, além do FMI, teriam papel relevante e (ii) o montante ideal de recursos a serem destinados ao Fundo, de maneira a dotá-lo de instrumentos de intervenção adequados sem lhe conceder excesso de autonomia. 


\subsubsection{O FMI ASSUME O COMANDO}

Depois de Toronto, as negociações do FMI com o México prosseguiram, mas em ritmo lento. Em meados de setembro, a equipe negociadora mexicana foi alterada, passando a ser composta por Silva Herzog, por Carlos Tello (novo presidente do Banco do México), e por Carlos Salinas de Gortari (representante do presidente-eleito Miguel de la Madrid). Era uma equipe dividida. Tello queria que o acordo com o FMI permitisse a continuidade dos controles cambiais em vigor, bem como exigisse cortes fiscais relativamente pequenos algo que o Fundo se recusava a aceitar. Salinas e Silva, por outro lado, aceitavam as condições do FMI, mas aparentemente prefeririam adiar a assinatura da Carta de Intenções para os últimos dias do governo de López Portillo, de maneira que o presidente que saía arcasse com o custo político do acordo e o novo presidente recebesse o dinheiro do empréstimo (Kraft, 1984, pp. 44-45).

Em 22 de outubro, os negociadores mexicanos foram para Washington e pediram a Volcker e Rhodes que pressionasse o FMI a aceitar termos mais flexíveis, mas não tiveram sucesso. No dia seguinte, encontraram-se com Larosière. Durante a reunião, a delegação mexicana se dividiu. Tello mais uma vez pediu a manutenção dos controles cambiais e defendeu que os gastos públicos não fossem reduzidos excessivamente para evitar uma contração econômica muito acentuada. Larosière discordou de Tello e foi apoiado por Silva Herzog. Por fim, Salinas quebrou o impasse alinhando-se a Larosière e Silva Herzog. Estavam estabelecidas as bases para um acordo (Kraft, 1984, pp. 45-46). No dia 8 de novembro, uma Carta de Intenções foi assinada pelo México e pelo FMI (Boughton, 2001, pp. 307-308).

Negociações com a Argentina também já estavam em andamento. A equipe argentina, liderada por Wehbe, negociava em várias frentes: além das tratativas com o FMI, que haviam começado em setembro, os argentinos requisitaram um empréstimo de US\$ 750 milhões do BIS e um empréstimo-ponte de US\$ 1,1 bilhão dos bancos comerciais. Confirmando em certa medida os temores de que o menor interesse dos EUA impediria a Argentina de conseguir condições tão boas quanto o México, o BIS se recusou a fazer o empréstimo por falta de garantias. Mas, no final de outubro, as autoridades argentinas chegaram a um acordo em princípio com o FMI e com os bancos. A moeda argentina foi desvalorizada em 13,5\%, e foi estabelecido novo regime cambial de desvalorizações sucessivas, acompanhando a inflação. 
O programa negociado pela equipe do FMI assumia que os bancos iriam apenas rolar os empréstimos já concedidos, e que todas as outras necessidades de financiamento (incluindo pagamentos de juros) seriam supridas por créditos oficiais, em particular o FMI. Larosière não concordou e pediu que o programa fosse modificado para partir da premissa que os bancos emprestariam cerca de US\$ 1,5 bilhão em "dinheiro novo" (Boughton, 2001, pp. 332$333)$.

Neste momento, estava claro para Larosière que o FMI não poderia prescindir dos bancos, que não poderiam parar de emprestar abruptamente $\mathrm{O}$ problema, porém, é que, diferentemente da situação normal na qual uma reestruturação é fechada para um devedor com problemas isolados em balança de pagamentos, o caráter global da crise criava fortes incentivos para os bancos, especialmente os menores, pararem totalmente de emprestar aos devedores. A questão, portanto, passava a ser como evitar o problema da carona entre os próprios bancos.

A estratégia de Larosière vinha sendo preparada desde a conferência de Toronto, e foi articulada com Volcker e Solomon do Fed, com Gordon Richardson do Banco da Inglaterra, e com o Departamento do Tesouro (Kraft, 1984, p. 48). Com a Carta de Intenções do México já acordada, e com as negociações com a Argentina próximas de um final exitoso, o diretorgerente do Fundo convocou os bancos que compunham o comitê consultivo do México e da Argentina a uma reunião na sede do Fed em 16 de novembro.

Larosière iniciou a reunião com uma apresentação sobre a situação do México. Descreveu as medidas acordadas no âmbito da Carta de Intenções e, por fim, chegou aos números mais importantes. Em 1983, o México teria de pagar cerca de US\$ 10 bilhões em juros sobre sua dívida; assim, a despeito do grande superávit na balança comercial que era esperado em virtude das medidas de austeridade, ainda teria um déficit em balança de pagamentos de US\$ 4,25 bilhões. Ademais, o país ainda teria de pagar US\$ 2,55 bilhões para pagar os empréstimos feitos pelo Fed e pelo BIS desde agosto. Por fim, seriam necessários mais US\$ 1,5 bilhão para recompor as reservas do país para um nível minimamente adequado. Desta forma, as necessidades de financiamento atingiriam, para 1983, a casa de US\$8,3 bilhões.

O Fundo ofereceria US\$ 1,3 bilhão, que era o máximo a que o país teria direito pelas regras da instituição. Estimava-se que outros credores oficiais emprestariam US\$ 2 bilhões em créditos comerciais. Sobravam US\$ 5 bilhões, a serem financiados pelos bancos. 
Larosière então soltou sua bomba: a participação dos bancos era tão importante que ele não aprovaria o financiamento do Fundo para o México a não ser que os bancos se comprometessem antes, por escrito, a emprestar os US\$ 5 bilhões necessários. O México já havia concordado em adotar medidas extremamente duras, como reduzir seu déficit público à metade em apenas um ano, e o FMI entendia que nada mais podia ser exigido do país; portanto, se os bancos se recusassem a levantar os fundos necessários, não haveria acordo e viria o default. Larosière fixou a data de 15 de dezembro como prazo para o comitê consultivo apresentar o compromisso dos bancos, pois no dia 23 ocorreria a reunião do Conselho Executivo que deveria aprovar a operação do Fundo com o México (Boughton, 2001, pp. 306305, Kraft, 1984, pp. 48-49).

$\mathrm{Na}$ mesma reunião, tratou-se do programa em negociação com a Argentina. A exemplo do programa com o México, Larosière exigiu que os bancos emprestassem cerca de US\$ 1,5 bilhão em "dinheiro novo" para levar o programa para a consideração do Conselho Executivo (Boughton, 2001, p. 333).

A atitude de Larosière causou choque no mercado financeiro. Um banqueiro presente à reunião afirmou ter pensado “quem esse cara pensa que é?”. Segundo um executivo de um banco regional californiano, "ninguém gosta de ser forçado a emprestar. Naturalmente nossa reação foi negativa". Um executivo de um banco inglês resumiu a reação desta forma: "Nós pensamos que [o FMI] iria aprovar o programa com o México, e colocar algum dinheiro. Nós pensamos que teríamos então a oportunidade de decidir se iríamos colaborar ou não. Quando Larosière disse que todo o acordo com o FMI dependia de os bancos colocarem US $\$ 5$ bilhões em dinheiro novo, nós ficamos chocados. Quando ele disse que tínhamos que ter o dinheiro até 15 de dezembro, nós ficamos indignados" "xix (Kraft, 1984, p. 49).

Na noite do mesmo dia 16, Volcker manifestou seu apoio a De Larosière. Em um discurso proferido em Boston, o presidente do Fed afirmou que a crise da dívida representava "uma ameaça sem precedentes desde o pós-guerra". Por isso, haveria "a mais forte comunidade de interesses entre devedores e credores, e entre os países subdesenvolvidos e industrializados”. Fez menção ao programa do FMI com o México, e à necessidade de que os bancos comerciais continuassem a emprestar ao país. Por fim, indicou que o Fed apoiava o FMI e prometeu relaxar a regulação do sistema bancário a quem aceitasse o plano de De Larosière: "Em tais casos, nos quais novos empréstimos facilitam o processo de ajustamento e permitem a um país fortalecer sua economia e manter o serviço de sua dívida de forma 
ordeira, novos créditos não deveriam ser objeto de críticas dos supervisores"xx (Kraft, 1984, p. 49). O próprio Anthony Solomon, que estava presente na reunião no Fed, já assegurara na ocasião que os empréstimos realizados no âmbito de um programa do FMI não seriam tratados como operações ordinárias (Boughton, 2001, p. 308).

A despeito da reação inicial negativa, os money center banks logo perceberam que Larosière estava oferecendo um bom negócio. Emprestando US\$ 5 bilhões em "dinheiro novo" para o México, os bancos recuperariam US\$ 10 bilhões em juros, além de evitar que um default os obrigasse a lançar dezenas de bilhões de dólares como perdas em seus balanços. Os US\$ 5 bilhões em novos créditos representavam um aumento nominal de $7 \%$ na exposição dos bancos ao México. Isto na prática reduziria a parcela de capital comprometida com o país, pois entre dezembro de 1977 e julho de 1982 o capital total dos bancos norte-americanos crescera à taxa média de 11,3\% (Batista Jr., 1988, p. 237, nota 16). O FMI, assim, indicava um caminho para os bancos credores reduzirem paulatinamente o risco representado pelos empréstimos aos países em desenvolvimento, mantendo elevada lucratividade sobre estes empréstimos.

As condições dos empréstimos também eram bastante vantajosas para os bancos. $\mathrm{O}$ dinheiro novo custaria ao México meio ponto percentual a mais do que custara o último empréstimo voluntário recebido pelo país, em julho - cujo custo já tinha sido extraordinariamente elevado (Kraft, 1984, p. 51). Este acordo também criava o precedente de que os reescalonamentos com outros países também teriam custos bastante elevados para os devedores.

Ademais, a proposta de Larosière servia para os grandes bancos enfrentarem o problema da carona, pressionando os pequenos a continuar emprestando. A chave do plano estava no programa negociado com o México, que geraria um superávit comercial da casa de US\$ 6 bilhões em 1983. Estes recursos seriam quase inteiramente transferidos aos bancos. $\mathrm{Na}$ prática, a recomposição das reservas e o pagamento dos empréstimos com o BIS e com o Fed viriam do FMI e dos próprios países industrializados. Era do interesse dos money center banks que todos os credores continuassem a emprestar ao país. Porém, se o FMI assinasse o acordo com o México antes de obter o compromisso dos credores privados de participar, isto maximizaria o problema de ação coletiva enfrentado pelos bancos, reduzindo o poder de barganha das grandes instituições sobre as menores. Afinal, sabendo que o México geraria superávits de US\$ 6 bilhões e o FMI emprestaria US\$1,3 bilhão, todas as instituições cujos 
créditos não fossem suficientemente grandes para individualmente comprometer o acordo teriam fortes incentivos para receber seu dinheiro e parar de emprestar, na expectativa de que outros atores arcariam com a diferença. Ao inverter a ordem do acordo - primeiro os bancos se comprometeriam a emprestar, depois o FMI fecharia o acordo com o país devedor - o Fundo aumentava o custo do comportamento auto-interessado para cada banco individual.

No dia 17, o comitê consultivo reuniu-se e aprovou a proposta apresentada por Larosière no dia anterior. Também decidiu rolar as dívidas mexicanas por 90 dias, de maneira a permitir a assinatura do acordo. Nos dias seguintes, o Fundo relaxaria um pouco suas condições com os bancos, aceitando aprovar o programa com o México se, até o dia 15 de dezembro, 90\% dos US\$ 5 bilhões requisitados fossem garantidos pelo comitê consultivo. Os bancos cobraram taxas bastante altas do México (obtendo, portanto, lucros elevados com a operação), mas a despeito disso chegaram ao dia 23 de dezembro com apenas US\$ 4,32 bilhões em empréstimos assinados. Este fato indicava que muitos bancos pequenos tinham se recusado a aderir ao plano, a despeito das pressões oriundas tanto dos grandes bancos quanto das autoridades do Tesouro e do Fed ${ }^{62}$. Mesmo assim, o Conselho Executivo do FMI aprovou o programa com o México (Boughton, 2001, pp. 310-311).

No dia 20 de dezembro, o FMI chegou a um acordo provisório com o Brasil e, no dia 31 de dezembro, o programa com a Argentina foi aprovado, bem como os novos empréstimos dos bancos comerciais para o país (Boughton, 2001, p. 334). No caso brasileiro, Larosière não chegou a apresentar o ultimato aos bancos, como fizera para convencê-los a emprestar para Argentina e México. No entanto, estava implícito que Larosière o faria, se julgasse necessário (ibidem, pp. 339-340). O fato de que nem sequer precisou fazê-lo indica que os bancos reconheceram que a estrutura do jogo entre eles já havia sido alterada em definitivo pelo Fundo.

\subsubsection{A Estratégia dos Cinco Pontos}

Embora a resposta inicial à crise mexicana tenha sido improvisada pelo governo norteamericano, no final do ano, com o estabelecimento dos programas do Fundo Monetário Internacional com México, Brasil e Argentina, já se configurava uma estratégia claramente definida para gerenciar o problema. Em novembro, logo depois da reunião de Larosière com

\footnotetext{
${ }^{62}$ Segundo afirmou um banqueiro ao New York Times, "se a pressão dos pares não funcionar" para convencer um banco a participar, ele "vai receber uma ligação de alguma pessoa do setor público", ou seja, do Tesouro ou do Fed (Bennett, 1982).
} 
os banqueiros na sede do Fed, o Departamento do Tesouro anunciava que um acordo havia sido atingido, em princípio, para recapitalizar o Fundo. De acordo com o acertado entre os Estados Unidos e os principais países industrializados, o FMI receberia, por meio de aumento das quotas e de aumento ou expansão dos mecanismos de financiamento de emergência, cerca de US\$ 30 bilhões em moedas conversíveis. O Tesouro, assim, anunciava que o FMI seria o gerente da crise internacional. Segundo Beryl Sprinkel, "o FMI tem que ser o principal ator nesta situação crítica, não o único, mas ele deve desempenhar o papel de protagonista" (Rowen, 1982i).

$\mathrm{O}$ acordo era parte de uma estratégia mais ampla, articulada entre setembro e novembro pelo FMI e pelo Fed, e aprovada pelo Tesouro. Levada a público pela primeira vez em 21 de dezembro de 1982, em audiência do Secretário do Tesouro Donald Regan perante a Comissão de Bancos, Finanças e Assuntos Urbanos da Câmara dos Deputados, a estratégia se baseava em cinco pontos ${ }^{63}$ :

1) Os países devedores deveriam ajustar suas economias, com o objetivo de reverter os déficits em balança comercial. Este ponto era considerado o mais importante por Regan. O Tesouro admitia que o ajustamento requerido não viria "de um dia para outro", sendo necessários esforços com duração de vários anos. Estes esforços visariam a corrigir os "desequilíbrios" que estariam na raiz da crise de endividamento. Tais desequilíbrios poderiam ser agrupados em: regimes rígidos de câmbio; protecionismo e subsídios; distorções de preços; empresas estatais ineficientes; crescimento excessivo da base monetária (causado por déficits fiscais); taxas de juros controladas e irreais, que desencorajavam a poupança e distorciam as taxas de retorno dos investimentos.

2) O FMI manteria oferta apropriada de recursos para financiar os déficits em balança de pagamentos. A vantagem de se usar o FMI para este propósito era que o Fundo poderia exigir, como condição para conceder seus empréstimos, que os devedores empreendessem os ajustes considerados necessários para equilibrar suas economias.

\footnotetext{
${ }^{63} \mathrm{O}$ que segue baseia-se nos documentos apresentados pelo Tesouro nas audiências de 14 de fevereiro de 1983 (U.S. Senate, 1983a) e 17 de maio de 1983 (idem, 1983b).
} 
3) Em caso de emergência, governos e bancos centrais dos países industrializados emprestariam recursos rapidamente, sem exigir as mesmas condições impostas pelo FMI. Estes recursos seriam sempre de curto prazo, e negociados em arranjos ad hoc.

4) Os bancos comerciais continuariam a emprestar recursos para os países em desenvolvimento que estivessem empreendendo programas de ajustamento econômico. Segundo Regan, os bancos deveriam não apenas rolar os créditos já existentes, mas também aumentar sua exposição, de maneira a permitir que os devedores ajustassem suas economias de forma ordenada.

5) Os países industrializados manteriam um ambiente econômico internacional saudável. Ou seja, não adotariam medidas protecionistas, combateriam a inflação e, na medida do possível, reduziriam as taxas de juros. O combate a eventuais tendências protecionistas seria de importância fundamental. Desta forma, os países devedores seriam capazes de aumentar suas exportações e, por conseguinte, gerar os superávits em balança comercial de que precisavam.

Os fiadores da estratégia eram o Fed e o Tesouro. Os bancos que tentavam colocar os reescalonamentos de dívida em risco eram pressionados diretamente pelo Fed. Por exemplo, em determinado momento um banco da Flórida entrou com processo contra alguns bancos mexicanos. Isto poderia engatilhar cláusulas de default cruzado que inviabilizariam o programa em negociação. Imediatamente o Fed apertou a fiscalização sobre o banco. "Isto foi o suficiente para nós", afirmou o presidente do banco, que retirou o processo logo depois (Kraft, 1984, p. 53). Richard Turner, do Comerica Bank, afirmou que "o extraodinário é como o governo e os reguladores se uniram em apoio ao aumento da exposição. Eles estão tão comprometidos que deixaram claro que quaisquer 'tecnicalidades' seriam resolvidas" (Lissakers, 1991, p. 207).

Uma análise mais detida da estratégia nos permite salientar alguns aspectos. Em primeiro lugar, apesar dos esforços dos países devedores para se diferenciarem - entre eles, as reiteradas afirmações das autoridades brasileiras de que o Brasil era "um caso completamente diferente do mexicano" (Veja, 1982c, p. 142) —, seriam todos tratados com a mesma receita: ajuste econômico supervisionado pelo FMI, financiamento por meio de recursos do Fundo e de bancos privados. Os governos dos países industrializados - em 
particular, o governo dos EUA — se manteriam publicamente afastados do processo. Só atuariam em caso de "emergência".

Em segundo lugar, o FMI seria usado como alavanca para forçar mudanças econômicas no nível doméstico dos países em desenvolvimento. A alternativa a um acordo com o FMI seria o default e a conseqüente exclusão do país do mercado financeiro internacional. Pacotes bilaterais de ajuda, como o que o Tesouro e o Fed montaram para o México em agosto, não seriam mais possíveis.

Terceiro, a Estratégia dos Cinco Pontos transformava um problema global — o risco sistêmico criado pelo endividamento excessivo e simultâneo dos principais países subdesenvolvidos - em uma série de questões bilaterais. A estratégia procurava minimizar o problema de ação coletiva dos credores ao mesmo tempo em que criava obstáculos para os devedores coordenarem suas posições, já que o Fundo sempre poderia punir ou premiar um ou outro devedor, concedendo-lhe termos piores ou melhores, de maneira a manter o conjunto dos devedores dividido.

Quarto, a abordagem escolhida pelo Tesouro mostrava-se muito boa para os grandes bancos. Como mostra Wellons (1985, pp. 458-459), a estratégia destas instituições baseava-se em dois pilares: manter o debate dentro do sistema financeiro e externalizar os custos. Durante todo o processo, os debates não saíram do nível das autoridades financeiras dos EUA e dos países devedores, e do FMI e dos bancos comerciais. Note-se também que, embora a estratégia tivesse implicações para o comércio internacional e a política externa dos EUA, nem o USTR nem o Departamento de Estado participaram da formulação da estratégia. Por fim, os custos do processo de reescalonamento das dívidas foram "externalizados" para os países devedores (que pagariam taxas de juros bastante elevadas pelo "dinheiro novo" que receberiam e ainda teriam de realizar ajustes macroeconômicos internos bastante onerosos em termos de bem-estar e crescimento econômico) e, em menor escala, para os países industrializados, que aumentaram seus empréstimos oficiais como parte da estratégia.

Quinto, se do ponto de vista dos países devedores o Fundo serviria como influência externa sobre o nível doméstico, do ponto de vista dos países industrializados a estratégia serviria para reduzir a influência do nível doméstico no ambiente externo. Como afirma Paulo Nogueira Batista Jr.,

O Congresso e a opinião pública nos EUA (e provavelmente nos demais países desenvolvidos) estariam de todo modo em forte oposição a qualquer medida que pudesse ser considerada uma tentativa de salvar os bancos com recursos do contribuinte. Mesmo propostas mais moderadas de intervenção enfrentam a resistência vigorosa de grupos de 
opinião que tendem a encarar os problemas atuais como resultado da imprevidência de bancos privados "irresponsáveis" e de países devedores "mal administrados". (Batista Jr., 1988, p. 242.)

A Estratégia dos Cinco Pontos contornava este problema político. Os países industrializados fariam uma única contribuição adicional ao FMI e delegariam a ele a autoridade para aplicar os recursos. O FMI recebia um mandato claro - emprestar recursos a países devedores em troca de ajustes econômicos — que a princípio não poderia ser alterado pelos parlamentos dos países-membros. No decorrer do processo de ajuste, os bancos reduziriam sua exposição aos países em desenvolvimento, sendo na prática "salvos" do excesso de empréstimos que concederam.

Sexto, ao adiantar, no terceiro ponto, que os países industrializados atuariam "em caso de emergência", os EUA admitiam que os verdadeiros fiadores da estabilidade do sistema financeiro internacional eram os bancos centrais dos países desenvolvidos. No limite, o único fiador do sistema era o Fed, o banco central capaz de emitir dólares. Mas o banco central norte-americano só atuaria diretamente em caso de risco sistêmico. A estratégia minimizava o risco político do governo e ao mesmo tempo sinalizava ao mercado a existência de um garantia implícita das autoridades dos EUA: o Fed e o Tesouro interviriam abertamente apenas em situação onde o apoio político para fazê-lo fosse fácil de obter (uma "emergência"), mas, em condições ordinárias, onde o apoio político fosse menor, a responsabilidade seria transferida para um órgão supranacional e menos permeável à influência política do nível doméstico norte-americano.

Finalmente, a estratégia só funcionaria se o FMI tivesse recursos suficientes para permitir que os bancos reduzissem gradativamente suas exposições aos países em desenvolvimento. O FMI seria o canal através do qual os governos dos países industrializados salvariam seus bancos. O problema era que os recursos do FMI eram finitos - e estavam diminuindo à medida que novos programas de ajuste eram acertados. Em outubro de 1982, o Fundo tinha cerca de US\$ 26 bilhões para emprestar. No começo de 1983, a soma já se reduzira a cerca de US\$ 10 bilhões (Delamaide, 1984, p. 149). Novas demandas de países devedores poderiam exaurir os recursos as reservas do Fundo e impedi-lo de agir. Por isso, era fundamental aumentar os recursos à sua disposição. O ano de 1983 seria marcado pela luta política, no Congresso norte-americano, para aumentar o capital do Fundo e, assim, levar a cabo a Estratégia dos Cinco Pontos. 


\section{A ampliação do capital do FMI no Congresso}

As negociações para o aumento do capital disponível para o FMI, que haviam se iniciado em setembro de 1982 em Toronto, foram finalizadas entre janeiro e fevereiro do ano seguinte. Em janeiro, os EUA concordaram em aumentar seus fundos comprometidos com os Arranjos Gerais de Tomada de Empréstimos (General Arrangements to Borrow, GAB) em US\$ 2,6 bilhões. De acordo com as regras do Fundo, os recursos usados pelo GAB não fazem parte do capital da instituição; mesmo assim, os EUA deveriam obter aprovação legislativa para aumentar sua contribuição. Em 11 de fevereiro de 1983, os membros do Conselho Executivo do FMI concordaram em aumentar o capital da instituição em 47,4\%, o que correspondia a US\$32,5 bilhões em fundos adicionais. Era um aumento bastante superior aos $25 \%$ que o Tesouro afirmava estar disposto a aceitar em setembro, mas também muito menor do que as autoridades européias e os bancos comerciais propunham na mesma ocasião (Farnsworth, 1982b). A parcela dos EUA no aumento das quotas seria de aproximadamente US\$ 5,6 bilhões ${ }^{64}$, também sujeita a aprovação legislativa. Desta forma, o total da contribuição que deveria ser votada pelo Congresso era de aproximadamente US\$ 8,4 bilhões.

A votação do aumento de capital do FMI representa uma oportunidade de verificar o grau de apoio do Congresso à Estratégia dos Cinco Pontos. Não é possível testar diretamente o grau de aprovação que as alternativas a esta estratégia obteriam; ou seja, não é possível verificar qual seria a posição do Congresso se o Tesouro tivesse adotado uma abordagem estritamente bilateral, pedindo aprovação parlamentar a um aumento de fundos para o ESF, a USAID e o Eximbank (para citar apenas algumas alternativas domésticas) que lhes permitissem fazer grandes empréstimos para o México, ou se, no sentido oposto, tivesse proposto dobrar ou triplicar o capital do FMI, como inicialmente defendido pelos países europeus. Estas alternativas não foram apresentadas, muito menos votadas. Mas a tramitação da proposta que o governo efetivamente apresentou nos permite verificar qual o espaço para que propostas alternativas fossem aprovadas pelo Congresso.

\footnotetext{
${ }^{64}$ Os valores em dólares são aproximados porque o capital do FMI é denominado em Direitos Especiais de Saque, a moeda contábil do FMI cujo valor flutua com relação ao dólar.
} 
O raciocínio é simples e se baseia na abordagem de jogos de dois níveis de Putnam (1988): o Executivo, a quem cabe submeter uma proposta ao Legislativo, pode antecipar a reação deste a qualquer proposta que apresente. Portanto, o Executivo conhece, dentre todas as alternativas de políticas de que dispõe, o conjunto das alternativas "aprováveis" pelo Legislativo (o win-set). Dentre as alternativas do win-set, o Executivo apresentará aquela que maximize sua utilidade. O resultado da votação no Congresso nos permite inferir se o Executivo, sabendo que suas preferências diferiam das do Legislativo, antecipou-se à reação deste e apresentou a melhor proposta "aprovável" ou se, confiante na existência de alinhamento de preferências, apresentou a melhor proposta possível. Se a proposta apresentada for aprovada com facilidade pelo Legislativo, podemos inferir que ela era a alternativa que maximizava a utilidade do Executivo dentre todas as alternativas possíveis (ou seja, a alternativa que melhor atendia ao interesse do Executivo estava dentro do win-set de alternativas "aprováveis"). Neste caso, havia alinhamento de preferências entre Executivo e Legislativo. No entanto, se a proposta encontrar dificuldades para sua aprovação no Legislativo, pode-se inferir que havia alternativas que seriam preferíveis para o Executivo, mas que foram descartadas por estarem fora do win-set.

Ao se analisar a tramitação da proposta de aumento do capital do FMI, constata-se que ela encontrou muitas dificuldades para sua aprovação. Como apresentada, a proposta não era aceitável para o "eleitor mediano" do Congresso; ela só foi aprovada porque o governo aceitou pagar um preço bastante elevado em termos de side payments. A partir desta análise, sustento que a delegação da crise da dívida ao FMI não era a política preferida pelo governo

- cujas autoridades tinham demonstrado repetidas vezes desconfiança com relação às instituições financeiras multilaterais - mas era a melhor política disponível para o governo naquele momento.

\subsection{O CONTEXTO POLÍTICO E A ESTRATÉGIA DO GOVERNO}

A 97- legislatura (1983-1984) representou um momento particularmente ruim da relação entre Executivo e Legislativo. Em 1981, o governo Reagan tinha logrado aprovar uma agenda ambiciosa de reformas econômicas neoliberais, que incluiu a redução de despesas federais com gastos sociais e cortes de impostos para os contribuintes com maior renda. Apesar de serem medidas polêmicas, elas foram aprovadas graças a uma estratégia do 
Executivo de usar seu poder de agenda ${ }^{65}$ e o capital político do governo recém-iniciado para, aproveitando-se das particularidades do processo legislativo em matéria orçamentária, combinar as diversas medidas em um único pacote apresentado ao Congresso e vendê-lo aos congressistas democratas centristas (Sinclair, 1985). Desta forma, como mostra Sinclair (1985, p. 294), a escolha para os deputados nunca foi "votar a favor ou contra cortes em programas sociais específicos, muitos dos quais eram muito populares": como todas as propostas de cortes foram combinadas em um único projeto de lei, aos deputados foi apresentada apenas a escolha entre votar a favor ou contra o programa econômico do novo governo.

O clima político se alterou em 1982. A recessão, o aumento do desemprego e o crescimento do déficit público erodiram o capital político do governo, e as eleições legislativas de novembro representaram uma derrota para os republicanos, que perderam 26 assentos para os democratas na Câmara de Representantes. Nesse contexto adverso foi apresentada a proposta de aumento do capital do FMI.

A estratégia do governo para a aprovação da proposta baseou-se em dois componentes. O primeiro foi o poder de agenda do Executivo. O governo apresentou uma proposta fechada, do tipo "pegar-ou-largar". Para o Congresso, as alternativas eram aceitar a proposta ou manter o status quo. Como mostram Romer e Rosenthal (1978), a posição do status quo fortemente influencia o resultado da votação. Neste caso, o governo procurava caracterizar o status quo como catastrófico: segundo ele, se o aumento do capital do FMI não fosse aprovado, a economia mundial entraria em colapso e a liderança econômica norteamericana seria comprometida. Claramente, quanto mais catastrófico o status quo parecesse aos congressistas, maior seria sua disposição a apoiar a proposta de aumento do capital do Fundo. No entanto, este componente, isoladamente, não foi suficiente para garantir a aprovação.

O segundo componente da estratégia foi a troca de votos, ou logrolling no jargão político norte-americano ${ }^{66}$. Em qualquer assembléia, os votantes têm intensidades de preferências diferentes com relação aos assuntos em pauta. O logrolling permite que os votantes maximizem sua utilidade, trocando seus votos a favor das propostas às quais são relativamente indiferentes por votos dos outros a favor das propostas às quais são fortemente

\footnotetext{
${ }^{65}$ Segundo a definição de Barbara Sinclair (1985, p. 293), um ator ou conjunto de atores detém poder de agenda quando sua definição de um problema - seus pressupostos e argumentos - é amplamente aceita e, assim, define as alternativas de políticas.
} 
favoráveis. Por exemplo, se o votante $A$ deseja muito a aprovação da proposta $x$ e é indiferente à proposta $y$, e $B$ deseja muito aprovar $y$ e opõe-se levemente a $x$, os dois podem trocar seus votos e aprovar as propostas às quais ambos são fortemente favoráveis. Num processo em que as votações ocorrem separadamente e em seqüência, há o risco de quebra do compromisso: uma vez que $A$ tenha ajudado a aprovar $y, B$ pode voltar atrás e votar contra $x$. $O$ processo legislativo norte-americano, no entanto, permite superar este problema, agregando diversas propostas num mesmo projeto. Assim, $x$ e $y$ podem ser combinados, formando a proposta $z$; um voto a favor de $z$ representa um voto simultaneamente a favor de $x$ e $y$.

Naturalmente, a prática de logrolling permite a formação de inúmeras coligações vencedoras - inclusive coligações que visem a barrar uma proposta à qual um conjunto de votantes oponha-se fortemente. O fator que determina qual coligação vencedora será formada é o poder de barganha de cada ator, ou seja, o que ele tem a oferecer em troca do apoio dos outros participantes à sua proposta. Neste sentido, o Executivo conta com a grande vantagem representada pelo poder de veto: o presidente pode, para obter apoio a uma proposta $x$, comprometer-se a não vetar uma proposta $y$, que, em outras circunstâncias, ele vetaria. Derrubar um veto requer o voto de dois terços do Congresso; portanto, ao comprometer-se a não vetar determinada medida, o governo na prática oferece o equivalente a dois terços dos votos do Congresso a favor desta medida em troca do apoio a uma proposta que ele deseje ver aprovada. Note-se que a credibilidade de seu compromisso pode ser assegurada por meio da agregação das diversas propostas num único pacote que inclua a medida que o governo tem forte interesse em ver aprovada; no jargão legislativo norte-americano, isto torna o conjunto das propostas "à prova de veto".

Como veremos, o pedido de aumento do capital do FMI foi aprovado somente depois que diversas outras medidas, algumas sem nenhuma relação com o tema, foram agregadas à proposta inicial. A última proposta agregada - a legislação sobre habitação — já havia até sido retirada da pauta legislativa, alguns meses antes, pois o governo ameaçara vetá-la.

\subsection{PONTOS PRINCIPAIS DO DEBATE}

Em 2 de março de 1983, duas propostas idênticas do Executivo sobre o aumento do capital do FMI foram apresentadas respectivamente à Câmara e ao Senado pelo deputado Fernand St. Germain e pelo senador Charles Percy (U.S. House, 1984a, p. 123). As propostas

\footnotetext{
${ }^{66}$ O trabalho seminal sobre logrolling é Tullock e Buchanan (1962).
} 
eram acompanhadas por uma exposição de motivos, assinada pelo presidente Reagan, que justificava o pedido de recursos com o argumento de que "estas medidas são necessárias agora porque a economia mundial enfrenta problemas econômicos e financeiros sem precedentes no pós-guerra" (ibidem, p. 115). A exemplo do que ocorrera em 1981, uma medida importante era apresentada em um único pacote que condensava a estratégia do governo, de maneira a limitar as alternativas dos congressistas a votar a favor ou contra toda a política do governo para a questão.

$\mathrm{O}$ argumento central do Tesouro, coerente com a estratégia de caracterizar o status quo como catastrófico, era que a crise da dívida era uma ameaça à estabilidade da economia mundial, e seu agravamento poderia causar desorganização econômica, redução do comércio internacional e, portanto, diminuição das exportações norte-americanas e queda do PIB e do nível de emprego do país. Nas palavras de Paul Volcker, a crise representava "uma ameaça à recuperação, aos empregos, e à prosperidade de nosso país, uma ameaça essencialmente sem paralelo no período do pós-guerra" (U.S. House, 1983b, p. 86). Neste contexto, o aumento dos recursos do FMI era "um elemento central de uma estratégia internacional acordada para lidar com a crise", como afirmou Donald Regan (U.S. Senate, 1983b, p. 2). A estratégia desenvolvida para superar a crise partia do pressuposto que os países devedores deveriam ajustar suas economias para aumentar sua capacidade de pagamento. Mas o principal problema a enfrentar relacionava-se à velocidade deste ajuste: "há um limite para a velocidade com que os principais ajustes podem ser feitos", e por isso "tentativas de promovê-los rápido demais podem ser desestabilizadores" (ibidem, p. 3). O FMI serviria para coordenar este ajuste ordenado das economias periféricas, dando-lhes tempo para tomar as medidas macroeconômicas necessárias para retornarem ao mercado voluntário de crédito.

Para o governo, era fundamental que a atividade do FMI não fosse vista como ajuda internacional para o desenvolvimento. $\mathrm{O}$ financiamento das atividades de ajuda internacional é, tradicionalmente, uma das questões mais contenciosas do relacionamento entre Executivo e Legislativo. Como autorizar gastos é atribuição constitucional da Câmara, a ajuda internacional oferece a esta casa a oportunidade de exercer quase a mesma influência que o Senado na formulação da política externa dos EUA. O resultado do cabo-de-guerra entre Legislativo e Executivo no orçamento de ajuda internacional já foi definida como "uma árvore de Natal de restrições" e emendas, que configuram a principal fonte de influência do Congresso em política externa (Pastor, 1982, pp. 252-253). 
Em seus diversos depoimentos ao Congresso, as autoridades do governo reafirmavam que o FMI é uma "instituição monetária", não uma instituição de desenvolvimento: como afirmou Donald Regan, "ele não financia barragens, cooperativas agrícolas, ou projetos de infraestrutura" (U.S. Senate, 1983b, p. 19). Os oponentes do aumento do capital do Fundo, por seu turno, adotavam a tática oposta e tentavam freqüentemente caracterizar as atividades do organismo como uma forma de ajuda internacional, com todos os defeitos e deficiências que ela envolve (U.S. Senate, 1983a, p. 9).

O governo sustentava que o envolvimento do FMI era necessário porque, como instituição monetária, ele era capaz de atrelar condicionalidades a suas operações, exigindo ajustes macroeconômicos que assegurariam a solvência dos países devedores e, a longo prazo, a estabilidade do sistema financeiro internacional. Segundo Donald Regan, "quando provê recursos temporários para um país que enfrenta problemas financeiros, o FMI procura assegurar que o país esteja adotando políticas que lhe permitam viver dentro de seus meios ou seja, que dentro de sua capacidade de obter recursos financeiros externos" (U.S. Senate, 1983a, p. 9, 1983b, p. 19). Nenhuma outra organização tinha capacidade, segundo as autoridades norte-americanas, de impor essas condições e verificar seu cumprimento. As condicionalidades é que faziam "o papel do FMI e a adequação de seus recursos tão importante" para a solução da crise, segundo Regan (idem, 1983a, p. 56).

A argumentação do governo não seria aceita facilmente. Durante os meses seguintes, a proposta do Executivo seria questionada tanto pela esquerda quanto pela direita. Os críticos podem ser agrupados em duas categorias: (i) os que discordavam da Estratégia dos Cinco Pontos como um todo e (ii) os que, embora aceitassem a lógica desta estratégia, questionavam o uso do FMI para executá-la.

\section{Críticos da Estratégia dos Cinco Pontos}

Os críticos da Estratégia dos Cinco Pontos podem ser divididos entre os que (i) duvidavam da gravidade da crise, (ii) consideravam os custos da estratégia excessivamente elevados para os EUA, (iii) priorizavam uma reforma da regulação do sistema financeiro, (iv) acusavam a estratégia de ser apenas uma operação de salvamento de bancos ou de países devedores, (v) julgavam que a estratégia não deveria contemplar determinados países considerados hostis ou descumpridores de normas internacionais, e (vi) consideravam que 
forçar fortes ajustes por parte de diversos países ao mesmo tempo agravaria a recessão mundial.

Dúvidas sobre a gravidade da crise: numerosos congressistas se mostravam céticos quanto à visão do Executivo sobre a gravidade da crise. Para eles, os problemas econômicos enfrentados pelos países devedores eram apenas conseqüência da recessão nos EUA e, portanto, tais problemas desapareceriam com a recuperação da economia norte-americana. Nota-se claramente que, em termos analíticos, o objetivo destes críticos era mostrar que o status quo (ou seja, a manutenção do capital do FMI no patamar vigente até então) não era tão desastroso quanto o Tesouro queria fazer parecer. Se tivesse sucesso, a estratégia obrigaria o Tesouro a aumentar suas concessões e, assim, aproximar sua proposta das preferências do Congresso.

Custo excessivo para os EUA: muitos críticos afirmavam que o custo do aumento das contribuições dos EUA para o FMI era excessivamente elevado, especialmente à luz dos seus crescentes déficits fiscais. Segundo Mark Hulbert, representante da Associação Nacional dos Contribuintes, a proposta de aumentar o capital do FMI "faz chacota de qualquer tentativa de controlar os gastos públicos"xxi (U.S. House, 1983c, p. 606). O governo procurou demonstrar, durante todos os debates, que a contribuição para o FMI não representava um aumento dos gastos públicos: o aumento das quotas do Fundo representava um investimento dos EUA na instituição, sem impacto orçamentário, e o comprometimento com o GAB era apenas uma promessa de emprestar recursos até o montante total comprometido, caso fosse necessário. Mas diversos críticos rejeitavam essa explicação. Alguns, como o ex-secretário do Tesouro William Simon, a caracterizavam como mero "passe de mágica" contábil, porque os ativos que os EUA recebem em troca de seus dólares (uma conta denominada em Direitos Especiais de Saque) não podem ser usados livremente. "Se fosse uma verdadeira troca de ativos", perguntava William Simon (1983), “qual seria o sentido do aumento das quotas?” Outros críticos argumentavam que o Tesouro subestimava os custos econômicos da operação com o FMI. Segundo estes críticos, os US\$ 8,4 bilhões destinados ao Fundo teriam de ser financiados como se fossem um aumento do déficit federal, o que causaria aumento da taxa de juros e, portanto, redução do crescimento econômico nos EUA. Como afirmou o senador conservador Gordon Humphrey (republicano de Connecticut), embora o governo estivesse tentando convencer o Congresso de que ele estava "simplesmente trocando ativos" com o 
FMI, haveria na verdade "custos econômicos muito reais envolvidos", pois, se a proposta do governo fosse aprovada, os contribuintes iriam descobrir que "haverá US\$ 8,5 bilhões a menos aqui em casa" (U.S. House, 1984a, p. 120).

Necessidade de solucionar falhas de regulação bancária: boa parte dos congressistas atribuía a crise a deficiências na legislação de supervisão bancária norte-americana. Desde o final dos anos 70, a falta de regulação do mercado de "eurodólares", cujo maior atrativo era justamente o fato de estar à margem de qualquer controle nacional, preocupava o Congresso (Parola, 1991, p. 57). A partir de 1982, começa um movimento mais forte em favor de um controle mais rígido destas operações. Quando, em 1983, o Tesouro e o Fed pediram ao Congresso a aprovação do aumento do capital do FMI, os membros da Comissão de Bancos do Senado decidiram condicionar a aprovação deste pedido à aprovação de uma reforma regulatória que fortalecesse a supervisão governamental sobre o sistema financeiro.

Para muitos congressistas, era importante sinalizar à opinião pública que eles não eram favoráveis a um simples salvamento de bancos com dinheiro público. Como afirmou o Senador John Heinz (republicano da Pensilvânia), presidente da Subcomissão de Bancos do Senado, "eu estou convencido de que a situação atual não corresponderia à descrição de uma crise tivessem os bancos de nossa Nação agido de forma mais conservadora e prudente" (U.S. Senate, 1983a, p. 2). A adoção de padrões mais rígidos de supervisão serviria para sinalizar ao eleitorado que o Congresso tomara medidas de longo prazo para evitar que a crise se repetisse, solucionando a lacuna regulatória referente ao novo fenômeno do financiamento privado dos déficits da balança de pagamentos de países em desenvolvimento (Lichtenstein, 1990, p. 243).

O problema desta iniciativa do Congresso era que ela ia de encontro à estratégia do Executivo para enfrentar a crise. Para funcionar, a Estratégia dos Cinco Pontos requereria uma postura flexível por parte das autoridades que supervisionavam os bancos: se os critérios de capitalização e desconcentração de risco fossem seguidos à risca, os grandes bancos seriam obrigados a reduzir drasticamente sua exposição aos países em desenvolvimento, o que agravaria a crise. Recorde-se que, para convencer os bancos regionais a participar do reescalonamento das dívidas do México e da Argentina, em novembro de 1982, o Fed assegurou que não condenaria as operações realizadas no âmbito destas renegociações.

Politicamente, a iniciativa do Congresso deixava o Executivo em situação delicada. A defesa pública de uma postura flexível das autoridades regulatórias era quase impossível, 
porque, à luz da percepção de que a crise da dívida fora resultado de um ambiente que favorecia o excesso de crédito aos países em desenvolvimento, seria difícil sustentar o argumento que mecanismos mais rígidos de controle da atividade bancária internacional não eram necessários (Parola, 1991, p. 56).

Por isso, com relação à mudança da regulamentação bancária proposta pelo Senado, o Executivo adotou uma estratégia negociadora low profile, diretamente junto à Comissão de Bancos, que visava a conter os danos que a nova legislação poderia causar. Pode-se encontrar o cerne do argumento no Memorando Conjunto sobre o Programa de Supervisão e Regulamentação Aperfeiçoadas de Empréstimos Internacionais, submetido à Comisão de Bancos pelo Conselho de Governadores do Federal Reserve System, pelo Escritório do Controlador da Moeda (Office of the Comptroller of the Currency, OCC) e pela Câmara Federal de Seguro de Depósito (Federal Deposit Insurance Corporation, FDIC). Segundo o memorando, a Estratégia dos Cinco Pontos

Destina-se a criar incentivos aos empréstimos prudentes, mas sem estabelecer obstáculos arbitrários a movimentações internacionais de capital ou impedir a continuidade de fluxos de crédito de tomadores idôneos. Dependendo de circunstâncias particulares, fluxos contínuos de capital a países basicamente dignos de crédito em atuais condições econômicas difíceis continuam a ser adequados - especialmente no contexto de programas de estabilização econômica aprovados pelo FMI - a fim de estimular ajustamentos apropriados da parte dos tomadores, para lhes manter a capacidade de pagar o serviço de sua dívida pendente e, por conseguinte, preserver a integridade dos ativos bancários existentes (apud Lichtenstein, 1990, p. 252).

Note-se que a argumentação do Executivo lançava mão dos programas de estabilização do FMI como uma justificativa para a manutenção de empréstimos aos países em crise a despeito de tais operações violarem as regras de supervisão bancária. Mais uma vez, o caráter alegadamente técnico do FMI era utilizado como justificativa para uma decisão política. No entanto, como já notado anteriormente, os próprios critérios adotados pelo FMI para fechar pacotes de ajuda são resultados de decisões políticas.

Salvamento de bancos: muitos congressistas afirmavam que a proposta do Executivo era nada mais que uma grande operação de salvamento dos bancos, que tinham emprestado de forma irresponsável e agora procuravam socializar suas perdas. Por exemplo, o deputado Ed Bethune (republicano do Arkansas) disse que depois dos "salvamentos" da Chrysler, das empresas de produtos florestais e da indústria de defesa, o governo agora propunha "o padrinho de todos eles", o salvamento dos bancos pelo FMI, enquanto o deputado Frank Annunzio (democrata de Illinois) afirmou que os contribuintes estavam sendo convocados a 
pagar pela falta de prudência dos bancos (U.S. House, 1984a, p. 116). Outros congressistas protestavam contra o que viam como tratamento diferenciado do Fed e do Tesouro aos money center banks. O Senador Jim Sasser (democrata do Tenessee), por exemplo, reclamou que, enquanto os acionistas de um pequeno banco de Knoxville perderam todo o seu investimento quando a instituição entrou em crise por causa de empréstimos arriscados, os acionistas dos grandes bancos, que tinham feito essencialmente a mesma coisa, recebiam ajuda do governo norte-americano. "Nós temos padrões de conduta diferentes para banqueiros domésticos e para banqueiros internacionais?", perguntou Sasser a Paul Volcker, durante seu depoimento no Senado (U.S. Senate, 1983a, p. 255).

Outros críticos mostravam descontentamento com o fato de que, para continuar a emprestar aos países que estavam recebendo ajuda do FMI, os bancos estavam cobrando juros ainda mais altos do que cobravam antes da crise. Desta forma, beneficiavam-se do problema, enquanto os custos das reestruturações das dívidas eram cobertos pelos contribuintes dos países industrializados e, principalmente, pelos países devedores. Como apontou Karin Lissakers em seu depoimento de 3 de maio de 1983 perante a Comissão de Bancos da Câmara dos Deputados, enquanto a Malásia, um país que não apresentava problemas de balança de pagamentos, obtinha crédito ao custo de 0,375 pontos percentuais sobre a LIBOR, o México, que dependia de empréstimos oficiais para manter o serviço de sua dívida privada, era obrigado a pagar 5 pontos percentuais sobre a LIBOR aos bancos (U.S. House, 1983c, p. 482). O custo maior dos empréstimos aos países em crise era atribuído ao maior risco representado pelos empréstimos a estes países. Lissakers refutava esta alegação argumentando que os bancos já estavam sendo beneficiados pelos programas coordenados pelo FMI e, portanto, precisavam arcar com parte dos seus custos:

É muito difícil, pelo menos para mim, entender por que os bancos deveriam receber um bônus pela participação em um pacote de resgate que muito lhes beneficia, e que, neste momento, lhes beneficia muito mais do que aos países devedores. Proteger os bancos de perdas catastróficas com empréstimos não requer necessariamente que se evite que tenham qualquer perda de receita com os empréstimos que se tornaram ruins. [...] O Congresso [...] deveria insistir em que [...] os bancos sejam forçados a contribuir com os custos da reestruturação, reduzindo suas receitas com juros sobre empréstimos novos e reescalonados $^{\text {xxii }}$. (U.S. House, 1983c, p. 483.)

$\mathrm{Na}$ base de muitas das críticas, estava uma desconfiança profunda do Congresso com relação aos bancos. Como mostra Parola (1991, p. 53), o sentimento do Congresso com relação ao setor bancário é historicamente hostil. Essa hostilidade aumentou com a Grande Depressão, de maneira que, "nem que seja apenas jogo cênico, nenhum congressista que 
pense seriamente em reeleição defenderá um interesse do setor bancário que implique em aumento da carga tributária" (ibidem).

Salvamento dos países devedores: enquanto algumas críticas eram direcionadas ao suposto salvamento dos bancos, outros acusavam a proposta do governo de promover um salvamento dos países devedores. Estes teriam tomado empréstimos de forma irresponsável, para financiar planos insustentáveis de desenvolvimento nacional. Como afirmou o senador James East (republicano da Carolina do Norte), a crise da dívida era resultado do "socialismo e da irresponsabilidade fiscal” do Terceiro Mundo (U.S. House, 1984a, p. 118). Outra crítica era dirigida ao fato de que os empréstimos dos bancos norte-americanos eram usados para financiar projetos ineficientes nos países subdesenvolvidos, que procuravam produzir internamente produtos já amplamente disponíveis no mercado internacional. Para estes críticos, o FMI estaria ajudando a perpetuar essa situação.

$\mathrm{Na}$ mesma linha, alguns críticos argumentavam que os programas do FMI apenas adiavam a adoção de medidas duras, por parte dos devedores, para restabelecer o equilíbrio macroeconômico.

Estes argumentos eram poderosos porque os países devedores tradicionalmente não dispunham de muita simpatia no Congresso. De fato, como estrangeiros que eram parte de um problema que ameaçava os EUA, eles eram excelentes candidatos ao papel de vilões da crise. No contexto da revolução conservadora empreendida pelo governo Reagan, as políticas nacional-desenvolvimentistas empreendidas pelos países devedores - muitas vezes confundidas com "socialismo" - eram vistas como a raiz dos seus problemas. Mesmo os congressistas que defendiam o aumento da contribuição ao FMI concordavam que os países em desenvolvimento tinham cometido erros de política econômica que os havia levado à crise.

Ajuda a países comunistas: uma questão que influenciou significativamente a tramitação da proposta foi se países comunistas seriam beneficiados pelo FMI. Para muitos congressistas, como o senador Gordon Humphrey, o Fundo fornecia recursos "para nossos adversários em todo o mundo" (U.S. House, 1984a, p. 120). Por isso, deputados e senadores insistiram em que a legislação exigisse que o representante dos EUA no Fundo se opusesse a empréstimos para países comunistas. 
Ajuda à África do Sul: a proposta de aumentar o capital do FMI também foi envolvida na campanha contra o apartheid na África do Sul. O empréstimo de US\$ 1,1 bilhão concedido pelo Fundo a este país em dezembro de 1982 enfureceu os integrantes do Black Caucus, o grupo que reúne os congressistas afro-americanos, pois teria ajudado o governo sul-africano a manter seu regime de segregação racial institucionalizada que negava direitos políticos à maioria negra. Em resposta, o presidente do Black Caucus, deputado Julian Dixon (democrata da Califórnia), apresentou emenda que obrigava o representante dos EUA no Fundo a se opor a empréstimos a "países que pratiquem apartheid".

A proposta de emenda levantou a questão da politização do Fundo, ou seja, de que a organização não poderia negar-se a emprestar a um país em razão de questões de política interna que não tinham relação com sua política macroeconômica. Para Regan, se os EUA insistissem em impor condições políticas para os empréstios do FMI, outros países fariam o mesmo e o Fundo "degeneraria em apenas outro fórum altamente carregado politicamente" (U.S. House, 1984a, p. 122). Os apoiadores da emenda, por seu turno, sustentavam que o apartheid era incompatível com os fundamentos morais do sistema multilateral, do qual o FMI fazia parte. Como afirmou o professor de Yale Colin Bradford, em sua audiência perante a Subcomissão de Comércio Internacional, Investimento e Política Monetária da Câmara,

Se pensarmos na origem do Fundo Monetário Internacional, do Banco Mundial e das Nações Unidas nos anos do pós-guerra, lembraremos que estas instituições foram fundadas sobre uma forte base moral com o objetivo de garantir o respeito aos direitos humanos e o exercício da democracia política, bem como a promoção do crescimento econômico no mundo do pós-guerra ${ }^{\text {xxiii }}$. (U.S. House, 1983c, p. 646.)

Ademais, os líderes do Black Caucus apontavam que o sistema de segregação impunha limites ao livre funcionamento do mercado de trabalho e impedia a liberdade econômica das populações negras da África do Sul. Como o FMI fora criado para promover o livre mercado, era portanto sua obrigação recusar-se a emprestar recursos a este país enquanto o apartheid estivesse em vigor. Segundo o deputado Dixon,

Também é visível que os Estados Unidos pouco fizeram para [...] calcular o quanto o apartheid contribui para os problemas econômicos que acossam a África do Sul, e quais ajustes poderiam ser feitos.

É irônico que [...] a instituição que manda os países devedores, tais como o Egito, aumentar os preços dos alimentos ou desvalorizar sua moeda, como no caso do Sudão, ou cortar serviços públicos e subsídios, como no caso da Jamaica, mantenha-se em silêncio com relação aos seus programas de ajuste estrutural com a África do Sul ${ }^{\text {xiv }}$. (U.S. House, 1983c, p. 638.)

$\mathrm{Na}$ mesma linha, outros críticos argumentaram que o regime de apartheid reduzia a produtividade total da economia, pois impedia que os negros ascendessem na escala social, o 
que diminuía a oferta de mão-de-obra especializada. Desta forma, causava distorções produtivas e uso ineficiente dos recursos nacionais. Por isso, o FMI deveria exigir o fim do regime como condição para realizar novos empréstimos à África do Sul.

Críticas aos ajustes exigidos dos países devedores: muitos críticos preocupavam-se com o fato de que os ajustes macroeconômicos exigidos pelo FMI para liberar seus empréstimos eram contracionistas e, como seriam executados em muitos países ao mesmo tempo, aprofundariam a recessão mundial. Neste sentido, os EUA sofreriam os efeitos das condicionalidades do Fundo em termos de redução de suas exportações e aumento do desemprego. Como afirmou o ex-secretário de Estado Henry Kissinger,

[...] mesmo um aumento nos recursos [do FMI] não pode resolver as contradições fundamentais na estratégia básica do FMI. Como condição a sua assistência, o FMI quase invariavelmente insiste em medidas que têm o efeito de contrair a economia, aumentar o desemprego e reduzir o consumo para reduzir as importações e transferir recursos para exportações. O problema é que as condições do FMI não podem funcionar se aplicadas ao mesmo tempo em muitos países, particularmente em um momento de recessão global (1983, p. 46).

Kissinger preocupava-se com as implicações dos programas do Fundo para a política externa norte-americana. Segundo ele, as condicionalidades do organismo ameaçariam "a evolução política interna de vários paísem em desenvolvimento", que por causa disso correriam o risco de cair em "regimes anti-ocidentais" (ibidem).

Esta preocupação levou o deputado Charles Schumer (democrata de Nova York) a propor que a aprovação do aumento de recursos ao FMI fosse condicionada a mudanças nos seus procedimentos operacionais, de maneira a assumir uma "visão global" da crise que convertesse os débitos de curto prazo junto aos bancos em débitos de longo prazo, a serem pagos com uma parcela fixa das exportações dos países devedores (U.S. House, 1983c, pp. 421-422).

Outro argumento, na mesma linha, sustentava que as taxas de juros cobradas pelos bancos comerciais para continuar emprestando no âmbito dos programas organizados pelo FMI eram tão altas que, em algum momento, os países devedores concluiriam que seria melhor repudiar os débitos do que continuar pagando uma dívida impagável e crescente.

\section{Críticos do papel do FMI na Estratégia dos Cinco Pontos}

Uma minoria de críticos aceitava a lógica econômica da Estratégia dos Cinco Pontos, mas questionava o papel central concedido ao FMI. Podemos dividir estes críticos entre (i) os 
que desconfiavam do FMI ou da própria abordagem multilateral, (ii) os que consideravam que havia um conflito de interesses entre o FMI como certificador das políticas econômicas dos países devedores e como emprestador para estes países, e (iii) os que sustentavam que o FMI deveria se financiar vendendo suas reservas de ouro ou tomando recursos no mercado privado.

Desconfiança quanto ao FMI e à abordagem multilateral: muitos críticos da proposta do governo, embora aceitassem a lógica da Estratégia dos Cinco Pontos, acusavam o FMI de gastar demais, especialmente com salários e benefícios concedidos a seus funcionários. Outros criticavam o Fundo por ter se tornado excessivamente poderoso e perseguir uma agenda própria. Como descreveu o deputado Ron Paul (republicano do Texas), o FMI era uma organização de "poderosos burocratas internacionais tentando tomar o dinheiro do povo americano a despeito de nossa resistência" (U.S. House,, 1984, p. 118). Para Milton Friedman (1983), o fim do sistema de taxas de câmbio rígidas, no começo dos anos 70, eliminou a razão de ser do FMI: "ele realmente não tem razão de existir. Mas, claro, uma agência governamental ou internacional jamais deixa de existir, se ela conseguir evitar”. Alguns críticos manifestavam sua desconfiança com relação ao papel que o FMI parecia arrogar-se de emprestador de última instância - papel que jamais fora aprovado pelo Congresso. Segundo James Davidson, presidente da National Taxpayers Union, "seu atual papel, para o qual se auto-indicou, como emprestador de última instância, serve apenas um propósito — canalizar doações dos contribuintes para salvar bancos comerciais imprudentes e seus clientes entre os governos do Terceiro Mundo e da Cortina de Ferro" (U.S. House, 1983c, p. 613).

Subjacente a estas críticas encontrava-se uma desconfiança com relação à própria abordagem multilateral, vista como um mecanismo no qual os EUA eram privados da oportunidade de obter vantagens em troca da ajuda que ofereciam aos países em desenvolvimento. Segundo William Simon (1983), "é difícil controlar os intermediários multilaterais, e nós caímos no hábito de subsidiar todo governo socialista no Terceiro Mundo". Para o ex-secretário do Tesouro, uma abordagem bilateral "nos permite evitar comprometer nossos interesses com nosso próprio dinheiro", pois a ajuda bilateral seria direcionada "onde ela pode melhor promover os interesses dos EUA [e] controlar a decisão sobre quando conceder mais", ao passo que a abordagem multilateral "sujeita nossa diplomacia a demandas sem fim do bloco de países que recebem ajuda" (ibidem). Para o exsecretário-assistente do Tesouro Paul Craig Roberts, "na melhor das hipóteses os salvamentos 
de países estrangeiros são uma forma de ajuda internacional" que, ao ser administrada pelo FMI, "reduz o controle e influência dos países doadores" (U.S. Senate, 1983b, p. 148). Por isso, Roberts propunha que a crise fosse gerida de forma bilateral ou, no máximo, por um arranjo multilateral ad hoc, pois não haveria "razões econômicas que impeçam a aliança ocidental de organizar ela mesma um salvamento e extrair benefícios políticos e estratégicos" dos países devedores (ibidem, p. 146).

Incompatibilidade do aumento dos recursos com o papel certificador do FMI: a crítica provavelmente mais sofisticada à proposta do governo afirmava haver uma incompatibilidade entre o papel de "certificador" que o FMI exercia com relação às políticas macroeconômicas dos países que buscavam seu apoio e seu papel como emprestador de última instância. No primeiro papel, o FMI indicava para o mercado financeiro internacional que o país em questão estava realizando ajustes macroeconômicos que lhe permitiriam honrar seus compromissos, o que levaria os bancos a voltar a lhe conceder empréstimos. No segundo papel, o FMI se colocava na situação de emprestar dinheiro para países que não tinham seguido políticas econômicas prudentes. Por isso, como afirmou Davidson, "mais de dois terços dos acordos stand-by falharam" (U.S. House, 1983c, p. 610). Um exemplo do conflito entre os dois papéis já estava ocorrendo no México, que não estaria conseguindo cumprir os termos do acordo fechado com o Fundo em dezembro de 1982. "Quando isso levar para outra crise”, avisou Davidson, “o FMI terá de escolher. Ou ele será uma agência de salvamento, ou ele vai manter a credibilidade de seu acordo e não ajudar [o México]" (ibidem). Na mesma linha, Fred Smith, presidente do Competitive Enterprise Institute, resumia seu argumento:

Suponha que a Standard \& Poor tivesse que classificar os papéis da cidade de Nova York enquanto ao mesmo tempo detivesse muitos destes papéis em seu portfólio. A S\&P teria fortes incentivos para evitar qualquer rebaixamento da classificação dos papéis que reduzisse o valor de seus próprios ativos. Ao contrário, ela seria tentada a trabalhar com as autoridades municipais para chegar ao que seria chamado de um sólido programa para recuperação gradual. Naturalmente, as autoridades municipais se aproveitariam do conflito de interesses da S\&P e reclamariam contra qualquer ajuste severo. [...] A S\&P então estaria sujeita ao mesmo tipo de chantagem política que o FMI sofre (Smith, 1984, p. 220).

Para estes autores, o argumento do governo de que o envolvimento do FMI era fundamental por causa de seu mecanismo de condicionalidades era invalidado pelo fato de que o papel do Fundo como emprestador de última instância o tornava inadequado para classificar de forma confiável o desempenho econômico dos países devedores. 
Existência de alternativas melhores de capitalização: outra crítica à proposta era o fato de que o FMI poderia levantar os recursos necessários de outras fontes, sem lançar mão de aumento do capital e, portanto, sem impor custos aos contribuintes dos Estados-membros. As duas alternativas geralmente apresentadas eram o financiamento direto do Fundo no mercado privado, a exemplo do que já fazia o Banco Mundial, e a venda de parte do ouro em poder da organização, cujo valor era estimado por alguns críticos em US\$ 50 bilhões. O Tesouro negava-se a aceitar esta alternativa, alegando que ela causaria grande depressão do preço internacional do metal, o que prejudicaria os próprios EUA, cujas reservas de ouro, no valor de cerca de US\$ 115 bilhões, eram ainda maiores do que as do FMI (U.S. Senate, 1983b, p. 25). Na verdade, desde setembro o Tesouro se opunha a um aumento muito grande do capital do Fundo porque temia que, com muitos recursos à disposição, ele adquirisse autonomia excessiva com relação ao governo norte-americano.

\subsection{A TRAMITAÇÃO DO PROJETO DE LEI}

A proposta enviada ao Senado em 3 de março (S. 695) passou inicialmente pela Comissão de Relações Exteriores. Em 24 de março, a comissão emitiu relatório, no qual apoiava "fortemente" a proposta com base nas audiências que realizara, nas quais teria havido "amplo consenso entre as testemunhas que a economia mundial está em seu mais agudo declínio desde a Grande Depressão". Estas audiências já haviam evidenciado o apoio da liderança da comissão à ampliação do capital do FMI, e por isso o relatório favorável à proposta não foi surpresa. Mesmo assim, o relatório adicionou algumas medidas ao texto original, de maneira a corrigir "falhas de informação" que "ameaçam a estabilidade do sistema monetário internacional”. Ademais, o relatório estipulava que quaisquer alterações ao "montante, termos ou condições" da participação dos EUA no GAB deveriam ser aprovadas pelo Congresso (U.S. House, 1984, pp. 123-124).

A seguir, a proposta foi enviada à Comissão de Bancos, Habitação e Assuntos Urbanos. Mais uma vez, o relatório foi favorável ao aumento do capital do Fundo. A Comissão de Bancos aceitou todas as mudanças propostas pela Comissão de Relações Exteriores, e acrescentou outras três novas, cujo objetivo eram reduzir as restrições à importação por parte dos países devedores (ibidem).

Além dessas mudanças, a Comissão de Bancos também acrescentou um capítulo importante e inteiramente novo, a Lei de Supervisão de Empréstimos Internacionais. Este 
capítulo foi o resultado dos debates, no âmbito da Comissão de Bancos, relativos à supervisão de operações financeiras internacionais. Como vimos, o Executivo tomou parte destes debates e procurou minimizar os danos que a nova legislação poderia causar para a Estratégia dos Cinco Pontos. Teve sucesso: como mostra Cynthia Lichtenstein, a Lei de Supervisão de Empréstimos Internacionais proposta pela Comissão de Bancos "não mudou em nenhum grau significativo a estrutura regulamentar que preside os empréstimos internacionais dos bancos comerciais norte-americanos" (1990, p. 267). A lei concedeu mais poderes às autoridades supervisoras, mas "nenhum desses poderes regulamentadores terá efeito importante algum sobre o volume de empréstimos internacionais feitos por bancos dos EUA", pois "o poder decisório quanto à prudência com relação a empréstimos internacionais acaba sempre onde começou, isto é, nas mãos da gerência e das diretorias os bancos multinacionais" (ibidem, pp. $267-268)^{67}$.

Na Câmara dos Deputados, a proposta do governo (H.R. 2957) passou primeiro pela Comissão de Bancos, que em seu relatório a expandiu substancialmente. A Comissão adicionou diversas medidas semelhantes às adotadas pelas comissões do Senado, mas, numa indicação do menor apoio da câmara baixa à proposta do governo, adotou prazos e critérios mais rígidos, que tinham o efeito de fortalecer as exigências. Foi incluída medida que exigia que a emissão de novos Direitos Especiais de Saque pelo FMI fosse aprovada pelo Congresso. Também foi incluída a obrigatoriedade de o representante dos EUA no Fundo opor-se a empréstimos para países que praticassem apartheid, a despeito da oposição do presidente da Subcomissão de Comércio Internacional.

A principal medida tomada pela Comissão de Bancos da Câmara foi a incorporação, à proposta relativa ao FMI, de legislação que dava continuidade às operações do Export-Import Bank (Eximbank) e que financiava a participação dos EUA no Banco Interamericano de Desenvolvimento (BID), no Banco de Desenvolvimento da Ásia e no Fundo de Desenvolvimento da África. Isto foi possível porque o Eximbank dispunha de grande apoio no Congresso por ser responsável por realizar créditos oficiais às exportações norteamericanas, enquanto as propostas relativas aos três bancos multilaterais foram apresentadas por deputados democratas que defendiam que a ajuda para o desenvolvimento fosse canalizada por organizações multilaterais como forma de reduzir a ingerência política do governo. As medidas não foram incluídas sem oposição; a deputada Marge Roukema

\footnotetext{
${ }^{67}$ Para duas excelentes análises sobre a Lei de Supervisão de Empréstimos Internacionais de 1983, cf.
} 
(republicana de Nova Jersey), por exemplo, objetou que as medidas "passaram correndo pela Comissão" e que a ligação entre os diferentes assuntos impediria a Câmara de "examinar as questões peculiares a cada uma dessas instituições" - o que era precisamente o propósito da tática (U.S. House, 1984a, p. 125).

Em virtude da reação positiva à proposta S. 695 nas comissões, e da repercussão favorável da Cúpula Econômica de Williamsburg, realizada no final de maio, a liderança do Senado, em acordo com a Casa Branca, decidiu levar a matéria a votação no plenário. A oposição centrou suas críticas no que via como um "salvamento dos bancos" à custa do contribuinte, mas finalmente foi vencida: em 8 de junho, o plenário aprovou a medida pela margem relativamente folgada de 55 votos a favor, 34 votos contra e 11 abstenções (U.S. House, 1984a, pp. 125-126).

Na Câmara, porém, a proposta enfrentou uma oposição muito mais acirrada. Formouse uma aliança entre grupos de diversos matizes ideológicos, como os conservadores Cato Institute, Heritage Foundation, e Free the Eagle Organization, os deputados republicanos Jack Kemp e Jerry Lewis, lado a lado com Ralph Nader, a Igreja Metodista, o Environment Policy Center e diversos congressistas liberais. A coligação, chamada de Coalizão dos Cidadãos Contra o Aumento do FMI, realizou uma campanha contra a proposta por meio de quase dois milhões de cartas e anúncios em rádio e televisão (Smith, 1984, pp. 215-216, Banker, 1983).

A oposição da Coalizão dos Cidadãos erodiu o apoio à proposta na Câmara, e em 21 de julho o speaker Tip O’Neill retirou o assunto da pauta pouco antes da votação porque uma contagem estimou que a proposta teria o apoio de apenas 130 dos 434 deputados. A despeito de a proposta originar-se de um governo republicano, os deputados do próprio partido se opunham a ela por uma margem de 102 a 65.

A partir de julho, o governo deu início a um intenso lobby para obter a aprovação da Câmara. Donald Regan e Paul Volcker reuniram-se pessoalmente com deputados para pedir apoio à medida. O secretário de Estado, George Schultz, todos os ex-secretários de Estado vivos e dez ex-secretários do Tesouro manifestaram publicamente seu apoio à proposta. $\mathrm{O}$ próprio presidente Ronald Reagan pediu apoio pessoalmente aos líderes republicanos da Câmara (U.S. House, 1984a, p. 127, Allen, 1983).

Mesmo assim, o projeto de lei parecia destinado a ser rejeitado. Para evitar a derrota, o Tesouro e os líderes da Câmara negociaram diretamente com os principais opositores da 
proposta. Como resultado dessas conversas, uma "emenda de compromisso" foi apresentada em 29 de julho. Esta emenda exigia que o representante dos EUA no Fundo se opusesse a qualquer uso do FMI para pagamento de empréstimos "imprudentes", solicitava a garantia do secretário do Tesouro de que os fundos adicionais reservados ao GAB eram necessários para impedir um colapso do sistema financeiro internacional, e proibia a prática, comum nos processos de renegociação realizados até então, de cobrança de taxas de reescalonamento por parte dos bancos (U.S. House, 1984a, p. 127). No debate em plenário, outras emendas foram acrescentadas, tais como (i) a proibição de empréstimos do Fundo a "ditaduras comunistas" (a emenda Gramm), (ii) a exigência de que os bancos pagassem ao Tesouro a diferença entre a rentabilidade de empréstimos tornados mais seguros pela ação do FMI e a rentabilidade dos títulos do Tesouro, e (iii) as exigências de que os salários dos funcionários do FMI fossem limitados ao teto de US\$ 67 mil anuais e que a organização não concedesse mais empréstimos pessoais subsidiados aos seus funcionários. Com estas emendas, consideradas muito restritivas pelo governo, a proposta foi finalmente aprovada na Câmara por uma margem apertada de 217 votos a favor, 211 contra e 5 abstenções. O apoio entre os deputados democratas foi maior do que entre os republicanos: daqueles, 55\% (145 em 262) votaram a favor, enquanto destes, apenas 43\% (72 em 166) foram favoráveis. O resultado mostrou que, sem as concessões incluídas na emenda de compromisso, a proposta certamente teria sido derrotada (U.S. House, 1984a, p. 128).

Como as propostas aprovadas nos plenários da Câmara e do Senado eram diferentes, seria necessário unificá-las, no processo chamado de "conciliação" na prática legislativa norte-americana. A conciliação fica a cargo de uma Comissão de Conciliação, formada por congressistas das duas casas. Uma vez conciliada a proposta legislativa, ela seria votada no plenário das duas casas. O processo ofereceria ao governo a oportunidade de livrar-se das emendas restritivas incluídas pela Câmara, oferecendo alguma outra concessão em troca.

No entanto, um conflito entre os deputados democratas e os republicanos paralisou a tramitação. Depois da aprovação do projeto na Câmara, o Comitê Republicano de Campanha para o Congresso montou uma ofensiva contra cerca de 20 deputados democratas que haviam votado a favor da proposta mas que tinham sido contrários à emenda Gramm, acusando-os de apoiar o comunismo. $\mathrm{O}$ ataque enfureceu os democratas, que já sentiam haver pago um preço político maior do que os deputados republicanos para aprovar uma proposta de interesse do 
governo, que era liderado por um presidente republicano. Em resposta, a liderança democrata exigiu uma carta de desagravo do presidente Reagan em apoio aos 20 deputados sob ataque.

A exigência dos democratas colocou o governo em posição muito desconfortável. O governo tinha interesse em acelerar a tramitação da proposta de aumento do capital do FMI (Lewis, 1983). Porém, para romper o impasse, teria de cumprir a exigência da bancada democrata, o que criaria tensão entre o presidente Reagan e os congressistas de seu próprio partido. No final de outubro, o governo, temendo que a proposta de aumento do capital do FMI fosse derrotada, acabou cedendo, e enviou uma carta aos deputados atacados pelo Comitê de Campanha republicano. $\mathrm{Na}$ correspondência, Reagan manifestava sua "forte satisfação" pelo apoio dos deputados democratas à proposta de legislação, e criticava a emenda Gramm por "desnecessariamente amarrar as mãos do FMI”. Este gesto permitiu que a tramitação da proposta fosse retomada (U.S. House, 1984. p. 129).

Mas ainda haveria mais um obstáculo a superar. Diversos congressistas democratas perceberam que poderiam extrair ainda mais concessões do governo. Por isso, decidiram usar a proposta do FMI para obter a aprovação de uma lei de habitação, desejada pelo partido há anos. Um projeto de lei sobre a matéria havia sido aprovado pela Câmara em julho, mas o governo ameaçou vetá-la, e o projeto similar que tramitava no Senado foi retirado antes de chegar no plenário. O projeto de lei sobre o FMI oferecia aos democratas uma oportunidade de reviver a lei de habitação que queriam. Depois de intensas negociações entre os deputados e a Casa Branca, a proposta de habitação foi incluída no projeto que já incluía, além do aumento do capital para o FMI, as medidas relativas ao Eximbank e aos bancos multilaterais de desenvolvimento (U.S. House, 1984. p. 130). Desta forma, o projeto de habitação tornouse à prova de veto, pois o presidente só pode vetar uma lei inteira e, evidentamente, não vetaria a lei que autorizava o aumento do capital do FMI, mesmo que ela fosse acompanhada por diversos dispositivos alheios a esta matéria. O discurso do deputado Barney Frank (democrata de Nova Jersey) no plenário da Câmara em favor da aprovação da lei explicitou a manobra: "Esta lei não é perfeita para nenhum assunto — nem para a habitação nem para o FMI. E seria melhor se os dois assuntos pudessem ser apresentados separadamente. Mas nestas circunstâncias peculiares, esta lei tem que agrupar tudo [...] para tornar a parte da habitação à prova de veto. [...] Votem contra isto hoje e vocês não terão outra lei do FMI, e não vai haver outra lei de habitação"xxv (U.S. House, 1984b, p. 272). 
Para acelerar a aprovação do pacote acordado e evitar que ele tivesse de passar pela Comissão de Conciliação, foi usada uma manobra legislativa. Em 17 de novembro, o senador Jake Garn (republicano de Utah), presidente da Comissão de Bancos do Senado, apresentou o pacote acordado anteriormente como uma emenda ao projeto de lei H.R. 3959, que autorizava verbas suplementares para o treinamento de veteranos. Este projeto de lei já tinha passado pela Comissão de Conciliação, e o relatório desta comissão já tinha sido aprovado pela Câmara. A "emenda" de Garn era muito maior do que a própria H.R. 3959 original, e continha pelo menos cinco leis sem relação direta entre si. Mesmo assim, foi aprovada no plenário do Senado por 67 votos a 30.

A emenda Garn representava um compromisso entre as propostas aprovadas no Senado e na Câmara, eliminando algumas das emendas consideradas excessivamente restritivas pelo governo. Por exemplo, as exigências de que o representante dos EUA no FMI vetasse empréstimos a países comunistas ou que praticassem apartheid foram diluídas, pois abriam a possibilidade de aprovação de empréstimos que, na avaliação do secretário do Tesouro, beneficiassem a maioria da população dos países em questão. A emenda Garn também removeu a limitação de salários dos funcionários do Fundo e a exigência de que os bancos pagassem ao Tesouro a diferença entre as taxas de juros de empréstimos a países sob programa do Fundo e as taxas de juros pagas pelos títulos norte-americanos. As outras emendas foram mantidas no texto final incorporado por Garn.

A manobra continuou na Câmara, para onde a H.R. 3959 emendada teve de retornar. A liderança democrata apresentou uma proposta de regra de votação do projeto de lei segundo a qual a emenda Garn era considerada lida e aprovada. Ao votar a favor ou contra a regra de votação proposta, os deputados estariam na verdade votando a favor ou contra a emenda Garn como um todo. Como propostas de regras só podem ser debatidas por uma hora e não são sujeitas a emendas, a manobra deixou os deputados apenas com a opção de aprovar ou rejeitar de uma vez todos os projetos incluídos no pacote acordado com a Casa Branca. Esta tática foi recebida com fortes protestos dos opositores do projeto. Segundo o deputado Ron Paul, "o processo que estamos sendo forçados a seguir hoje aqui é a maior prova de que o povo americano não apóia o salvamento dos bancos e seus empréstimos ruins"xxvi (U.S. House, 1984b, p. 252). Mesmo assim, a proposta de regra foi aprovada por 226 votos a favor, 186 contra e 22 abstenções, e assim a emenda Garn foi incorporada ao texto final da H.R. 3959. O 
projeto de lei foi finalmente promulgado pelo presidente Reagan em 30 de novembro, como Public Law 98-181 (U.S. House, 1984a, pp. 130-132).

\subsection{CONCLUSÃO}

A partir de setembro de 1982, quando pressionadas a aceitar um aumento de $100 \%$ ou $200 \%$ no capital do FMI, as autoridades norte-americanas recusavam-se sequer a considerar essa possibilidade, afirmando que o Congresso jamais aprovaria tal aumento. Diversas autoridades de outros governos chegaram a suspeitar que o Executivo usava o Congresso como um escudo para negar-se a fazer o que não era de seu interesse. Por exemplo, segundo Darrel Delamaide "o governo [dos EUA] parecia brandir o Congresso da mesma forma que os políticos do Terceiro Mundo às vezes brandiam o FMI - um bastão que os levava a fazer aquilo que, de qualquer forma, desejavam fazer" (1984, p. 150). A análise da tramitação da proposta de aumento de $47,5 \%$ do capital do Fundo mostra, no entanto, que isso não era verdade.

O governo encontrou muitas dificuldades para aprovar a proposta apresentada, a despeito de possuir o poder de agenda e ter procurado definir o problema em seus termos ou seja, estabilidade do sistema financeiro, e não ajuda internacional, como queriam vários oposicionistas. No decorrer do processo, teve de ceder e permitir que diversos grupos adicionassem novos dispositivos, algumas vezes sem relação com a legislação original, para montar uma coalizão vencedora e lograr a aprovação da proposta. Como afirmou Ron Paul, "se o povo Americano apoiasse essa [...] política [...], esta legislação teria sido aprovada no começo do último verão"xxvii (U.S. House, 1984b, p. 252).

Uma análise das críticas à proposta do governo nos permite inferir que tipos de propostas alternativas teriam mais possibilidade de serem aprovadas. Os críticos mais conservadores mostraram-se contrários à delegação ao FMI, em parte por entenderem que o Fundo reduzia o poder dos EUA de promover seus interesses no gerenciamento da crise da dívida, mas em grande parte por oposição doutrinária a qualquer forma de ajuda aos países devedores e por intuírem que a delegação ao FMI retirava o assunto da esfera da política doméstica norte-americana. A maior parte das críticas, porém, concentrou-se na própria Estratégia dos Cinco Pontos, vista por alguns como uma forma de salvar os bancos, criticada por outros por transferir todos os custos do ajuste para os países devedores, e considerada 
contraproducente por um terceiro grupo porque baseava-se em promover uma contração das importações de muitos países importantes ao mesmo tempo.

A questão, portanto, é: sem a delegação ao FMI, o núcleo da Estratégia dos Cinco Pontos poderia ser aprovado? A análise deste capítulo oferece fortes indícios de que, sem o recurso ao FMI, isto seria impossível. Como a maior parte das críticas concentrou-se nos aspectos operacionais da estratégia, é possível inferir que, se ela não tivesse sido "embalada" em um pacote fechado e apresentado de uma vez pelo governo, e se este não tivesse aceitado a inclusão de outros projetos de legislação, a Estratégia dos Cinco Pontos teria sido derrotada ou, no mínimo, profundamente modificada. 


\section{O Plano Baker}

A atuação do governo norte-americano, cristalizada na Estratégia dos Cinco Pontos, logrou impedir um colapso do sistema financeiro internacional em virtude da crise da dívida. Graças a esta estratégia, os bancos conseguiram reduzir sua exposição aos países em desenvolvimento, o que diminuiu os riscos de uma crise sistêmica. Mesmo assim, em outubro de 1985, o novo secretário do Tesouro, James Baker, anunciou um novo plano para a gestão da crise da dívida. Este novo plano admitia que a estratégia anterior, baseada na austeridade físcal para a geração de superávits comerciais, não fora capaz de evitar a estagnação econômica dos países em desenvolvimento, e introduzia novos elementos com o objetivo de fomentar o "crescimento sustentado" destes países.

O chamado "Plano Baker" foi visto, a princípio, como uma ruptura com a Estratégia dos Cinco Pontos. Por um lado, o plano parecia uma admissão de que a estratégia anterior não funcionara e que precisaria ser mudada, de maneira a reduzir a custo do ajuste arcado pelos países em desenvolvimento e aumentar o comprometimento dos bancos credores ${ }^{68}$. Por outro, o Plano Baker conferia papel importante ao Banco Mundial, como uma agência de fomento a reformas estruturais que colocariam os países devedores de volta ao caminho do crescimento econômico. Para alguns autores, a entrada do Banco Mundial na estratégia indicava que o FMI perdia sua posição privilegiada na gerência da crise ${ }^{69}$.

Este capítulo argumenta que, ao contrário dessas visões, o Plano Baker representou uma continuidade da Estratégia dos Cinco Pontos, e que o FMI continuou a ser o gerente da crise da dívida. Sustento que o objetivo principal do Plano era manter a iniciativa política sobre a crise da dívida nas mãos do Executivo norte-americano, num momento em que o Congresso, preocupado com o impacto da Estratégia dos Cinco Pontos sobre o comércio externo dos EUA, adotava postura mais assertiva e começava a promover alternativas à abordagem do governo. Nesse sentido, o Plano Baker visava a manter o enquadramento do problema da dívida como um tema de política externa, e não como uma questão de política doméstica norte-americana. Para atingir esse objetivo, o Banco Mundial foi incorporado à

\footnotetext{
${ }^{68}$ Para exemplos dessa visão, cf. Lehman (1994), Volcker e Gyohten (1992).

${ }^{69}$ Exemplos dessa visão são Bogdanowicz-Bindert (1985), Payer (1986), Kuczynski (1988, p. 95), e o depoimento de Stanley Fischer à Comissão Econômica Conjunta em janeiro de 1986 (U.S. Congress, 1986a, p. $31)$.
} 
estratégia de gerenciamento da crise porque dispunha de recursos que poderiam ser imediatamente mobilizados, sem necessidade de o governo norte-americano voltar a solicitar recursos ao Congresso. Por fim, o capítulo também propõe uma explicação para o fato de que o Banco Mundial foi ignorado pelo Tesouro e pelo Fed em 1982-1983 mas passou a ser considerado parceiro importante do Executivo norte-americano em 1985.

\subsection{OS BANCOS SE FORTALECEM}

Graças à Estratégia dos Cinco Pontos, os bancos conseguiram reduzir sua exposição aos principais países devedores, sistematicamente recebendo mais dinheiro em forma de juros do que concediam em forma de empréstimos. Afinal, como afirma Parola (1991, p. 84), “o sentido último [da Estratégia dos Cinco Pontos] consistia em que os bancos emprestavam 'new money' de forma que os países endividados pudessem lhes devolver esse dinheiro sob a forma de serviço da dívida”. Com efeito, entre 1982 e 1985, a despeito de participarem dos mecanismos de concerted lending liderados pelo FMI, tanto os grandes bancos quanto os pequenos e médios lograram diminuir sua exposição aos países em desenvolvimento, como mostram as tabelas 6.1 (relativa aos money center banks) e 6.2 (relativa aos outros bancos norte-americanos). Ademais, a despeito de estar em curso a maior crise financeira desde os anos 30, a lucratividade dos grandes bancos aumentou no período, como mostra a Tabela 6.3. O total dos lucros dos nove maiores bancos norte-americanos cresceu 21,5\% entre 1982 e 1985, e o lucro conjunto dos três bancos com maior exposição aos países em desenvolvimento no final de 1982 (Manufacturers Hanover, Citibank e Chemical) aumentou 42,6\% no período. Os dividendos distribuídos pelos nove maiores bancos acompanharam a tendência, apresentando aumento de 56,6\% no período (Tabela 6.4). O aumento dos juros cobrados pelos bancos dos países devedores explica este aumento de lucratividade a despeito do aumento do risco percebido nas operações internacionais dos grandes bancos, pois nenhum banco sofreu perdas significativas com sua carteira de empréstimos a países em desenvolvimento (Parola, 1991, p. 91).

Note-se que, a despeito de terem conseguido reduzir suas exposições aos países em desenvolvimento, os grandes bancos continuaram perigosamente vulneráveis a um default simultâneo de vários devedores. Para estes bancos, a intervenção do Tesouro, do Fed e do FMI continuava necessária. O mesmo não pode ser dito para os bancos menores. A Tabela 6.2 também mostra que os bancos médios e pequenos conseguiram reduzir sua exposição aos 
países em desenvolvimento de forma mais rápida do que os grandes bancos. Este fato refletiu a menor disposição daqueles bancos de colaborar com o concerted lending. Verifica-se que, a partir de 1984, aumentou o conflito entre os bancos grandes e os pequenos nos processos de renegociação das dívidas, e tornou-se prática comum que alguns bancos ameaçassem abandonar as negociações para reduzir sua exposição ou obter concessões especiais dos países devedores (Volcker e Gyohten, 1992, pp. 212-213). O acirramento das divisões entre os bancos ameaçava inviabilizar a Estratégia dos Cinco Pontos, cujo objetivo era reduzir a exposição dos grandes bancos aos países em desenvolvimento, pois uma debandada dos bancos menores obrigaria os grandes bancos a aumentar o volume de recursos emprestados a estes países e, portanto, a elevar sua exposição a estes devedores.

Tabela 6.1

Exposição dos money center banks norte-americanos a países selecionados, 1982-1986

Montantes em US\$ milhões

\begin{tabular}{llllll}
\hline País & $\mathbf{1 9 8 2}$ & $\mathbf{1 9 8 3}$ & $\mathbf{1 9 8 4}$ & $\mathbf{1 9 8 5}$ & $\mathbf{1 9 8 6}$ (set) \\
\hline Argentina & & & & & \\
Montante & $5.125,2$ & $5.353,8$ & $5.106,1$ & $5.874,7$ & $5,914,0$ \\
\% do capital & $17,7 \%$ & $17,0 \%$ & $13,9 \%$ & $13,9 \%$ & $13,1 \%$ \\
\% dos ativos & $0,9 \%$ & $0,9 \%$ & $0,9 \%$ & $0,9 \%$ & $1,0 \%$ \\
\hline Brasil & & & & \\
Montante & $13.296,2$ & $13.298,4$ & $15.800,2$ & $15.550,1$ & $15.000,0$ \\
\% do capital & $45,8 \%$ & $42,2 \%$ & $43,1 \%$ & $36,8 \%$ & $33,2 \%$ \\
\% dos ativos & $2,3 \%$ & $2,3 \%$ & $2,7 \%$ & $2,5 \%$ & $2,4 \%$ \\
\hline Chile & & & & & \\
Montante & $3.326,5 \%$ & $3.438,5$ & $3.823,9$ & $4.067,1$ & $4.136,0$ \\
$\%$ do capital & $11,5 \%$ & $10,9 \%$ & $10,4 \%$ & $9,6 \%$ & $9,2 \%$ \\
\% dos ativos & $0,6 \%$ & $0,6 \%$ & $0,6 \%$ & $0,7 \%$ & $0,7 \%$ \\
\hline Colômbia & & & & & \\
Montante & $2.225,4$ & $2.240,3$ & $2.181,3$ & $1.923,8$ & $1.448,0$ \\
\% do capital & $7,7 \%$ & $7,1 \%$ & $5,9 \%$ & $4,5 \%$ & $3,2 \%$ \\
\% dos ativos & $0,4 \%$ & $0,4 \%$ & $0,4 \%$ & $0,3 \%$ & $0,2 \%$ \\
\hline
\end{tabular}

Filipinas 


\begin{tabular}{|c|c|c|c|c|c|}
\hline Montante & $3.881,6$ & $3.930,7$ & $3.756,1$ & $3.790,8$ & $3.567,0$ \\
\hline$\%$ do capital & $13,4 \%$ & $12,5 \%$ & $10,2 \%$ & $9,0 \%$ & $7,9 \%$ \\
\hline$\%$ dos ativos & $0,7 \%$ & $0,7 \%$ & $0,6 \%$ & $0,6 \%$ & $0,6 \%$ \\
\hline \multicolumn{6}{|l|}{ Iugoslávia } \\
\hline Montante & $1.460,8$ & $1.556,7$ & $1.502,6$ & $1.522,2$ & $1.351,0$ \\
\hline$\%$ do capital & $5,0 \%$ & $4,9 \%$ & $4,1 \%$ & $3,6 \%$ & $3,0 \%$ \\
\hline$\%$ dos ativos & $0,2 \%$ & $0,3 \%$ & $0,3 \%$ & $0,2 \%$ & $0,2 \%$ \\
\hline \multicolumn{6}{|l|}{ México } \\
\hline Montante & $12.861,6$ & $14.127,1$ & $14.693,3$ & $14.087,3$ & $13.428,0$ \\
\hline$\%$ do capital & $44,4 \%$ & $44,8 \%$ & $40,0 \%$ & $33,3 \%$ & $29,7 \%$ \\
\hline$\%$ dos ativos & $2,2 \%$ & $2,4 \%$ & $2,5 \%$ & $2,3 \%$ & $2,2 \%$ \\
\hline \multicolumn{6}{|l|}{ Nigéria } \\
\hline Montante & $1.448,4$ & $1.531,7$ & $1.146,5$ & 903,4 & 688,0 \\
\hline$\%$ do capital & $5,0 \%$ & $4,9 \%$ & $3,1 \%$ & $2,1 \%$ & $1,5 \%$ \\
\hline$\%$ dos ativos & $0,2 \%$ & $0,3 \%$ & $0,2 \%$ & $0,1 \%$ & $0,1 \%$ \\
\hline \multicolumn{6}{|l|}{ Peru } \\
\hline Montante & $1.364,2$ & $1.352,9$ & $1.295,3$ & 956,3 & 758,0 \\
\hline$\%$ do capital & $4,7 \%$ & $4,3 \%$ & $3,5 \%$ & $2,3 \%$ & $1,7 \%$ \\
\hline$\%$ dos ativos & $0,2 \%$ & $0,2 \%$ & $0,2 \%$ & $0,2 \%$ & $0,1 \%$ \\
\hline \multicolumn{6}{|l|}{ Venezuela } \\
\hline Montante & $7.803,9$ & $7.635,7$ & $7.435,1$ & $7.127,6$ & $6.744,0$ \\
\hline$\%$ do capital & $26,9 \%$ & $24,2 \%$ & $20,3 \%$ & $16,9 \%$ & $14,9 \%$ \\
\hline$\%$ dos ativos & $1,3 \%$ & $1,3 \%$ & $1,3 \%$ & $1,1 \%$ & $1,1 \%$ \\
\hline \multicolumn{6}{|l|}{ “Baker 15” } \\
\hline Montante & $55.868,3$ & $57.829,9$ & $60.029,5$ & $58.850,5$ & $56.117,0$ \\
\hline$\%$ do capital & $192,6 \%$ & $183,6 \%$ & $163,6 \%$ & $139,1 \%$ & $124,2 \%$ \\
\hline$\%$ dos ativos & $9,5 \%$ & $9,9 \%$ & $10,2 \%$ & $9,4 \%$ & $9,0 \%$ \\
\hline \multicolumn{6}{|c|}{ Brasil+México+Argentina } \\
\hline Montante & $31.283,0$ & $32.779,3$ & $35.599,7$ & $35.512,1$ & $34.342,0$ \\
\hline$\%$ do capital & $107,8 \%$ & $104,1 \%$ & $97,0 \%$ & $84,0 \%$ & $76,0 \%$ \\
\hline$\%$ dos ativos & $5,3 \%$ & $5,6 \%$ & $6,0 \%$ & $5,7 \%$ & $5,5 \%$ \\
\hline
\end{tabular}

Fonte: Wertman, 1987b, pp. 6-7. 
Tabela 6.2

Exposição dos bancos médios e pequenos dos EUA a países selecionados, 1982-1986

Montantes em US\$ milhões

\begin{tabular}{|c|c|c|c|c|c|}
\hline País & 1982 & 1983 & 1984 & 1985 & 1986 (set) \\
\hline \multicolumn{6}{|l|}{ Argentina } \\
\hline Montante & $3.105,8$ & $3.150,1$ & $2.868,7$ & $2.535,9$ & $2.546,0$ \\
\hline$\%$ do capital & $7,5 \%$ & $6,6 \%$ & $5,2 \%$ & $4,0 \%$ & $3,8 \%$ \\
\hline$\%$ dos ativos & $0,5 \%$ & $0,4 \%$ & $0,3 \%$ & $0,3 \%$ & $0,3 \%$ \\
\hline \multicolumn{6}{|l|}{ Brasil } \\
\hline Montante & $7.141,3$ & $7.354,1$ & $8.068,3$ & $7.245,5$ & $7.109,0$ \\
\hline$\%$ do capital & $17,2 \%$ & $15,4 \%$ & $14,5 \%$ & $11,5 \%$ & $10,5 \%$ \\
\hline$\%$ dos ativos & $1,1 \%$ & $1,0 \%$ & $1,0 \%$ & $0,8 \%$ & $0,8 \%$ \\
\hline \multicolumn{6}{|l|}{ Chile } \\
\hline Montante & $2.753,9$ & $2.762,0$ & $2.873,5$ & $2.502,0$ & $2.398,0$ \\
\hline$\%$ do capital & $6,6 \%$ & $5,8 \%$ & $5,2 \%$ & $4,0 \%$ & $3,5 \%$ \\
\hline$\%$ dos ativos & $0,4 \%$ & $0,4 \%$ & $0,3 \%$ & $0,3 \%$ & $0,3 \%$ \\
\hline \multicolumn{6}{|l|}{ Colômbia } \\
\hline Montante & 970,3 & $1.075,9$ & 785,2 & 701,6 & 566,0 \\
\hline$\%$ do capital & $2,3 \%$ & $2,2 \%$ & $1,4 \%$ & $1,1 \%$ & $0,8 \%$ \\
\hline$\%$ dos ativos & $0,1 \%$ & $0,1 \%$ & $0,1 \%$ & $0,1 \%$ & $0,1 \%$ \\
\hline \multicolumn{6}{|l|}{ Filipinas } \\
\hline Montante & $1.863,9$ & $2.130,7$ & $1.697,6$ & $1.627,5$ & $1.373,0$ \\
\hline$\%$ do capital & $4,5 \%$ & $4,4 \%$ & $3,1 \%$ & $2,6 \%$ & $2,0 \%$ \\
\hline$\%$ dos ativos & $0,3 \%$ & $0,3 \%$ & $0,2 \%$ & $0,2 \%$ & $0,1 \%$ \\
\hline \multicolumn{6}{|l|}{ Iugoslávia } \\
\hline Montante & 858,7 & 875,3 & 876,7 & 875,9 & 738,0 \\
\hline$\%$ do capital & $2,1 \%$ & $1,8 \%$ & $1,6 \%$ & $1,4 \%$ & $1,1 \%$ \\
\hline$\%$ dos ativos & $0,1 \%$ & $0,1 \%$ & $0,1 \%$ & $0,1 \%$ & $0,1 \%$ \\
\hline \multicolumn{6}{|l|}{ México } \\
\hline Montante & $11.515,1$ & $12.210,5$ & $11.831,6$ & $10.847,0$ & $10.318,0$ \\
\hline$\%$ do capital & $27,7 \%$ & $25,5 \%$ & $21,3 \%$ & $17,2 \%$ & $15,2 \%$ \\
\hline$\%$ dos ativos & $1,7 \%$ & $1,6 \%$ & $1,4 \%$ & $1,2 \%$ & $1,1 \%$ \\
\hline
\end{tabular}




\begin{tabular}{|c|c|c|c|c|c|}
\hline \multicolumn{6}{|l|}{ Nigéria } \\
\hline Montante & 405,6 & 534,7 & 392,3 & 295,1 & 240,0 \\
\hline$\%$ do capital & $1,0 \%$ & $1,1 \%$ & $0,7 \%$ & $0,5 \%$ & $0,4 \%$ \\
\hline$\%$ dos ativos & $0,1 \%$ & $0,1 \%$ & $0,0 \%$ & $0,0 \%$ & $0,0 \%$ \\
\hline \multicolumn{6}{|l|}{ Peru } \\
\hline Montante & $1.176,8$ & $1.142,4$ & $1.061,5$ & 697,9 & 556,0 \\
\hline$\%$ do capital & $2,8 \%$ & $2,4 \%$ & $1,9 \%$ & $1,1 \%$ & $0,8 \%$ \\
\hline$\%$ dos ativos & $0,2 \%$ & $0,2 \%$ & $0,1 \%$ & $0,1 \%$ & $0,1 \%$ \\
\hline \multicolumn{6}{|l|}{ Venezuela } \\
\hline Montante & $3.771,4$ & $3.621,6$ & $3.377,5$ & $2.962,8$ & $2.699,0$ \\
\hline$\%$ do capital & $9,1 \%$ & $7,6 \%$ & $6,1 \%$ & $4,7 \%$ & $4,0 \%$ \\
\hline$\%$ dos ativos & $0,6 \%$ & $0,5 \%$ & $0,4 \%$ & $0,3 \%$ & $0,3 \%$ \\
\hline \multicolumn{6}{|l|}{ “Baker 15” } \\
\hline Montante & $35.215,5$ & $36.398,4$ & $33.345,4$ & $31.674,3$ & $29.886,0$ \\
\hline$\%$ do capital & $84,7 \%$ & $76,0 \%$ & $63,7 \%$ & $50,2 \%$ & $44,1 \%$ \\
\hline$\%$ dos ativos & $5.2 \%$ & $4,8 \%$ & $4,3 \%$ & $3,5 \%$ & $3,2 \%$ \\
\hline \multicolumn{6}{|c|}{ Brasil+México+Argentina } \\
\hline Montante & $21.762,2$ & $22.714,7$ & $22.768,6$ & $20.628,4$ & $19.973,0$ \\
\hline$\%$ do capital & $52,3 \%$ & $47,4 \%$ & $41,0 \%$ & $32,7 \%$ & $29,5 \%$ \\
\hline$\%$ dos ativos & $3,2 \%$ & $3,0 \%$ & $2,8 \%$ & $2,3 \%$ & $2,2 \%$ \\
\hline
\end{tabular}

Fonte: Wertman, 1987b, pp. 8-9. 
Tabela 6.3

Lucro líquido dos nove maiores bancos dos EUA, 1982-1985

(em US\$ milhões)

\begin{tabular}{lrrrrr}
\hline Banco & $\mathbf{1 9 8 2}$ & $\mathbf{1 9 8 3}$ & $\mathbf{1 9 8 4}$ & $\mathbf{1 9 8 5}$ & Variação \\
\hline Bankers Trust & 223 & 257 & 307 & 371 & $66,4 \%$ \\
Bank of America & 395 & 390 & 346 & -337 & $-185,3 \%$ \\
Chase Manhattan & 307 & 430 & 406 & 565 & $84,0 \%$ \\
Chemical & 241 & 306 & 341 & 390 & $61,8 \%$ \\
Citicorp & 723 & 860 & 890 & 998 & $38,0 \%$ \\
Continental Illinois & 84 & 101 & -1.088 & 134 & $59,5 \%$ \\
First Chicago & 137 & 184 & 86 & 169 & $23,4 \%$ \\
Manufacturers Hanover & 295 & 337 & 353 & 407 & $38,0 \%$ \\
Morgan Guaranty & 394 & 460 & 538 & 705 & $78,9 \%$ \\
Total & $\mathbf{2 . 7 9 9}$ & $\mathbf{3 . 3 2 5}$ & $\mathbf{2 . 1 7 9}$ & $\mathbf{3 . 4 0 2}$ & $\mathbf{2 1 , 5 \%}$ \\
\hline
\end{tabular}

Fonte: Solomon Brothers Inc., A review of bank performance, 1986 edition. Apud Parola (1991), p. 88.

Tabela 6.4

Dividendos distribuídos pelos nove maiores bancos dos EUA, 1982-1985

(em US\$ milhões)

\begin{tabular}{lrrrrr}
\hline Banco & $\mathbf{1 9 8 2}$ & $\mathbf{1 9 8 3}$ & $\mathbf{1 9 8 4}$ & $\mathbf{1 9 8 5}$ & Variação \\
\hline Bankers Trust & 71,2 & 81,0 & 92,0 & 106,6 & $49,7 \%$ \\
Bank of America & 229,4 & 291,5 & 307,5 & 246,7 & $7,5 \%$ \\
Chase Manhattan & 162,4 & 173,1 & 209,3 & 229,4 & $41,3 \%$ \\
Chemical & 103,8 & 129,8 & 150,0 & 155,8 & $50,1 \%$ \\
Citicorp & 222,0 & 271,0 & 319,0 & 353,0 & $59,0 \%$ \\
Continental Illinois & 80,0 & 83,0 & 25,0 & 0,0 & $-100,0 \%$ \\
First Chicago & 50,9 & 73,3 & 93,1 & 94,6 & $85,9 \%$ \\
Manufacturers Hanover & 125,4 & 154,4 & 196,2 & 197,7 & $57,7 \%$ \\
Morgan Guaranty & 136,0 & 168,0 & 190,0 & 210,0 & $54,4 \%$ \\
Total & $\mathbf{1 . 1 8 1 , 1}$ & $\mathbf{1 . 4 2 5 , 1}$ & $\mathbf{1 . 5 8 2 , 1}$ & $\mathbf{1 . 5 9 3 , 8}$ & $\mathbf{3 4 , 9 \%}$ \\
\hline
\end{tabular}

Fonte: Solomon Brothers Inc., A review of bank performance, 1986 edition. Apud Parola (1991), p. 89. 


\subsection{OS DEVEDORES PAGAM A CONTA}

Estava claro que quem tinha arcado com a maior parte do custo da crise da dívida tinham sido os países devedores, que não tinham recuperado o acesso ao mercado privado e continuavam a depender de esquemas de "empréstimos involuntários" para manterem os pagamentos em dia. Para estes países, os planos de ajuste macroeconômico tinham causado estagnação, inflação e acentuada queda nos níveis de vida - exatamente no momento em que a América do Sul passava por uma transição democrática que colocava fim a duas décadas de golpes de Estado e regimes autoritários.

Como vimos, o principal componente dos planos de ajuste macroeconômicos aos quais os países devedores se submeteram era o aumento das exportações e a redução das importações. Dados do FMI indicam a magnitude do ajuste externo: as importações dos países da América Latina e Caribe caíram de US\$ 105,1 bilhões em 1981 para US\$ 64,6 bilhões em 1984, uma redução de quase $40 \%$ em três anos. As exportações, por seu turno, que atingiram US\$ 99,7 bilhões em 1981, caíram para US\$ 90,3 bilhões no ano seguinte, subiram para US\$ 91,9 bilhões em 1983 e atingiram US\$ 101,6 bilhões em 1984. Como o volume exportado aumentou, o fato de que as receitas de exportação em 1984 foram quase iguais às de 1981 indica uma grande queda dos preços dos produtos exportados pela América Latina no período (Kuczynski, 1988, p. 154).

O ajuste externo das economias dos países devedores teve profundas conseqüências domésticas. Entre 1976 e 1980, as economias latino-americanas cresceram a uma taxa média de 2,9\% ao ano. Em 1981, já em conseqüência do "choque Volcker", o PIB da região caiu 0,7\%. Em 1982, ano que marca o início da crise da dívida, a queda seria ainda maior, atingindo 2,7\%. Como resultado das políticas de ajuste macroeconômico exigidas pelo FMI, em 1983 o PIB da região caiu assustadores 5,3\%, e em 1984 manteve-se praticamente constante, subindo pífios 0,2\%. A inflação explodiu, e em 1984 atingiu 195\% no Brasil, 675\% na Argentina e $1.085 \%$ na Bolívia. Se, do ponto de vista econômico, os ajustes macroeconômicos foram dolorosos, do ponto de vista social seus efeitos foram dramáticos. Por exemplo, entre 1981 e 1984, os salários reais caíram cerca de 30\% no México e 23\% no Brasil (O’Brien, 1986, p. 47).

A deterioração dos níveis de vida nos países devedores foi tão acentuada que, em 1984, eles tentariam articular uma resposta conjunta à crise. No entanto, como veremos, os 
países devedores nunca foram capazes de montar uma ameaça crível à abordagem em vigor para a crise da dívida.

Em janeiro de 1984, foi realizada em Quito a Conferência Econômica Latinoamericana, uma reunião de chefes de Estado e chanceleres da qual resultaram a Declaração e o Plano de Ação de Quito. O Plano de Ação deixava clara a intenção de convocar os países desenvolvidos a envolverem-se abertamente nas negociações relativas à dívida externa, ao afirmar que "a responsabilidade pelo problema da dívida deve ser compartilhada pelos países devedores e credores, o sistema bancário privado e as organizações financeiras multilaterais" (Roett, 1985, p. 231). Dessa forma, os líderes dos países devedores rompiam a postura que tinham adotado até então e procuravam reenquadrar o problema da dívida, indo além do aspecto técnico-financeiro e buscando transformá-lo em questão abertamente política.

Em maio, em resposta a um aumento da prime rate de $11 \%$ para $12,5 \%$ em apenas dois meses, os presidentes da Argentina, do Brasil, da Colômbia e do México emitiram uma declaração conjunta na qual afirmavam que "não aceitamos ser empurrados a uma situação de insolvência forçada e estagnação econômica continuada", e convocando uma reunião de ministros da Fazenda e Chanceleres para o mês seguinte, em Cartagena (Roett, 1985, p. 233).

A reunião de Cartagena reuniu ministros de sete países latinoamericanos (Argentina, Brasil, Colômbia, Equador, México, Peru, e Venezuela) cujas dívidas externas somavam US\$ 286 bilhões. Quatro outros países (Bolívia, Chile, República Dominicana e Uruguai) tomaram parte do encontro como observadores. A reunião resultou no chamado Consenso de Cartagena (Parola, 1991, pp. 66-72, Roett, 1985, pp. 234-235). Do ponto de vista técnico, o documento continha diversas propostas, algumas das quais já circulavam há algum tempo. Entre eles, destacavam-se:

a) mudanças na forma de cálculo dos juros, de maneira a que os países devedores pagassem um prêmio sobre o custo do capital para os bancos, e não sobre a prime rate;

b) limitação do pagamento de juros a uma porcentagem das exportações, a exemplo do que a Bolívia já vinha fazendo;

c) mudanças nas condicionalidades do FMI, de maneira a enfatizar o crescimento econômico (Business Week, 1984). 
Mas a novidade mais importante do Consenso de Cartagena não era o conjunto de propostas técnicas, mas sim o fato de que o encontro foi comandado pelos chanceleres, e não pelos ministros da Fazenda (Roett, 1985, p. 235). Desta forma, ficava reforçado o enquadramento da crise da dívida, por parte dos países devedores, como um problema político, e não apenas financeiro. Vista como um problema político, a crise não se esgotava nas negociações técnicas de reescalonamentos, mas passava a envolver o conjunto do relacionamento entre os governos dos países devedores e dos países credores.

No entanto, a própria reunião de Cartagena evidenciou as dificuldades de articulação entre os países latinoamericanos. Antes mesmo do início do encontro, o vice-ministro da Fazenda do México, Francisco Suarez, declarou que "nós enfaticamente rejeitamos a formação de um clube de devedores" (Roett, 1985, p. 238). Embora alguns países (particularmente Argentina e Bolívia) tentassem estabelecer um mecanismo de coordenação dos devedores nas negociações, a declaração final mencionou apenas um "mecanismo regional de consultas". A declaração também assegurou que os países participantes honrariam suas dívidas e não tinham intenção de formar um cartel de devedores (Roett, 1985, p. 235, Business Week, 1984).

Coincidentemente ou não, a primeira "resposta" do governo norte-americano à reunião de Cartagena foi o aumento de meio ponto percentual na prime rate. As propostas técnicas dos países devedores foram praticamente ignoradas. O elemento que obteve a resposta mais forte foi a politização do problema da dívida. Segundo Sergio Amaral, as autoridades norteamericanas reagiram considerando que "a partipação dos chanceleres [na reunião de Cartagena] não é legítima, porque introduz um elemento político estranho à estratégia [para a crise da dívida], que se propõe a ser neutra, técnica, 'de mercado'” (Parola, 1991, p. 68).

Nova reunião do Grupo de Cartagena foi realizada em Mar del Plata, em setembro, às vésperas da reunião anual conjunta do FMI e do Banco Mundial. O clima entre os participantes, no entanto, já era diferente do que fora em junho. O México acabara de renegociar sua dívida em condições que considerava favoráveis; Brasil e Venezuela estavam em processo de negociação, e até mesmo a Argentina já se mostrava disposta a buscar um acordo com o FMI. Numa demonstração de que o grupo perdia sua força, o único resultado da reunião foi o pedido de realizar uma conferência conjunta entre representantes dos países devedores e credores para buscar uma solução coletiva para crise (Roett, 1985, p. 236). 
Os signatários do Consenso de Cartagena enfrentavam um clássico problema de ação coletiva: a cada integrante do grupo interessava uma moratória coletiva dos outros membros do grupo, mas nenhum deles se mostrava disposto a arcar com as conseqüências de sua própria moratória. Como mostra Guillermo O’Donnell, os países credores dispunham de dois instrumentos para manter os devedores em um “dilema do prisioneiro". Primeiro, os credores podiam punir um país que tentasse agir unilateralmente, rompesse com o regime em vigor e suspendesse seus pagamentos (um recalcitrante). Segundo, os credores podiam oferecer sidepayments a outros países que pudessem estar tentados a seguir a liderança do devedor recalcitrante. Desta forma, os credores podiam impedir a formação de um bloco entre os diversos países, punindo os que eventualmente tentassem iniciar um movimento de devedores e premiando os que se negassem a aderir a este movimento (O’Donnell, 1985, 1987). Desta forma, mesmo nos momentos de maior ativismo político conjunto, era praticamente impossível aos países devedores fazer ameaças críveis de rompimento com o regime.

O FMI era fundamental nessa estratégia porque permitia que esse jogo de incentivos e punições fosse executado sem a interferência do Congresso norte-americano. Como os EUA eram, por sua posição de hegemon do sistema, o garantidor da estabilidade do regime, seria muito mais difícil levar a cabo as táticas que criavam um problema de ação coletiva entre os devedores se o Congresso, cuja visão é fragmentada e voltada às preferências dos distritos eleitorais, tivesse grande influência sobre o tema.

A dinâmica política interna dos países devedores também funcionava como freio a eventuais iniciativas unilaterais em oposição ao sistema financeiro internacional. Internamente, os países latino-americanos possuem classes médias politicamente ativas e importantes, e que seriam as principais perdedoras em caso de rompimento. Ademais, como mostra Kuczynski, as classes médias latino-americanas possuíam uma atitude naturalmente contrária a ações que consideravam "irresponsáveis" no tocante à dívida externa, preferindo o caminho da negociação com os credores (1988, p. 149). Esta atitude estava presente também na maior parte dos líderes da região, que aceitavam os pressupostos dos credores com relação à dívida e por isso relutavam em assumir posições que pudessem ser consideradas radicais (Whitehead, 1989, p. 152) ${ }^{70}$. Por fim, como ficaria mais claro no episódio da moratória brasileira de 1987, os credores dispunham de meios para mobilizar segmentos domésticos dos

\footnotetext{
${ }^{70}$ Whitehead admite, porém, que o agravamento da crise econômica levou à erosão desta atitude a favor da "responsabiliade", e abriu espaço para posturas mais radicais (1989, p. 155, nota 18).
} 
países devedores de maneira e erodir o capital político de governos que tentassem agir unilateralmente contra o regime da dívida (O’Donnell, 1987).

O momento político dos países da América Latina tornou ainda mais difícil a emergência de uma liderança na região e contribuiu para sua divisão: enquanto o México se concentrava em usar sua proximidade com os EUA para obter concessões, Brasil e Argentina passavam por difíceis transições para regimes democráticos, o que impediu os presidentes Figueiredo, Sarney e Alfonsín de liderar um esforço político mais organizado por parte dos países latinoamericanos.

A rigor, a única iniciativa de oposição aos credores ocorreu em julho de 1985 . Na ocasião, o presidente recém-empossado do Peru, Alan García, decidiu romper relações com o FMI e declarar unilateralmente a limitação dos pagamentos relativos ao serviço da dívida a $10 \%$ das exportações do país. O anúncio bombástico de García representava apenas uma tentativa de capitalizar politicamente sobre uma situação já em andamento, pois a limitação “anunciada” em sua posse já estava em vigor desde abril de 1984 (Kuczynski, 1987, p. 150).

Reunidos para a posse de García, diversos chefes de Estado da região assinaram a Declaração de Lima, que defendia o conceito de co-responsabilidade dos países devedores e credores e reiterava a proposta de vincular os pagamentos de juros às receitas de exportação (Parola, 1991, p. 71). A despeito das palavras de apoio, nenhum outro país da região seguiu a iniciativa do Peru, que se viu isolado pela comunidade financeira internacional. Este fato ficaria evidente na reunião anual conjunta do FMI e do Banco Mundial, realizada em outubro em Seul, na qual Larosière elogiaria o ministro da Economia da Argentina, Juan Sourroille, pelo sucesso do Plano Austral em conter a inflação, enquanto o ministro da Fazenda do Brasil, Dilson Funaro, afirmaria publicamente que "nossa posição não é de confronto" (Veja, 1985). Mais uma vez, verificava-se que a retórica dos países devedores era muito mais radical do que a prática.

Em outubro, James Baker apresentaria seu plano para a crise da dívida dos países em desenvolvimento. $\mathrm{O}$ fato de que esta apresentação se deu apenas três meses depois do anúncio de Alan García levou alguns autores a afirmar que a iniciativa do Peru teria sido o fator que convenceu Baker a formular e propor seu plano. Parola, por exemplo, afirma que James Baker, presente à cerimônia de posse de Alan García, "percebe como preocupantes os sinais emitidos e, de retorno a Washington, começa a trabalhar em uma modificação da postura norte-americana" (1991, p. 71). Segundo o autor, um elemento que explicaria o Plano Baker é 
o fato de que "a própria pressão dos endividados ameaçava colocar em risco o objetivo último da estratégia em curso desde 1982", que era "resguardar os interesses do sistema bancário norte-americano" (ibidem, p. 82). Esta explicação é reforçada por Paul Volcker, que em seu livro afirma que Baker ficava incomodado com os lucros excessivos dos bancos. "Você sabe, isso não parece correto. Os bancos deveriam estar tendo algumas perdas aqui”, teria dito Baker a Volcker (Volcker e Gyohten, 1992, p. 213). Robin Broad, que trabalhava no Departamento do Tesouro à época do Plano Baker, afirmou em artigo publicado no New York Times que o Plano Baker "foi simplesmente uma tentativa de roubar a cena do [...] presidente Alan García", e que "foi calculado para recuperar a iniciativa" (Broad, 1987). Autoridades do próprio Tesouro chegaram a afirmar que a "politização" da crise por parte dos devedores foi um fator que levou James Baker a propor seu plano: segundo depoimento ao Congresso do secretário-assistente de Assuntos Internacionais do Tesouro, David Mulford, era preciso desenvolver "uma resposta positiva [...] à retórica mais elevada e à politização da questão da dívida por parte de diversos países devedores” (U.S. Congress, 1986a, p. 8).

Embora seja possível ver o Plano Baker como uma resposta à pressão dos países devedores, esta pressão isoladamente não é suficiente para explicar as razões que orientaram sua apresentação, nem os mecanismos que acabaram incluídos na iniciativa. Por um lado, a união dos países latino-americanos em torno Consenso de Cartagena era pouco mais que retórica vazia. As chancelarias, que assumiram a liderança do processo, dispunham de pouco conhecimento técnico, o que se reflete nas declarações amplas e genéricas que resultaram dos diversos encontros do grupo. No nível doméstico, os chanceleres não conseguiram se sobrepor a seus colegas nos respectivos ministérios da Fazenda, cuja atitude era mais favorável à cooperação com os credores. Por fim, México e Brasil mostraram-se claramente opostos a qualquer medida que pudesse ser vista como cartel de devedores - e a ausência dos dois maiores devedores inviabilizava qualquer movimento neste sentido, pois impedia a formação de uma coalizão que pudessem ameaçar a declaração de um default simultâneo suficientemente grande para desestabilizar o sistema bancário norte-americano. Por isso, como afirma Pedro-Pablo Kuczynski, o Consenso de Cartagena não passava de "um tigre de papel" (1987, p. 151).

Por outro lado, uma análise do próprio Plano Baker mostra que ele não oferecia grandes concessões aos países devedores. Como veremos, o FMI, a despeito da oposição dos países devedores, continuaria a ter papel central; a abordagem caso-a-caso continuaria em 
vigor; os fundos oriundos dos bancos multilaterais de desenvolvimento seriam condicionados a difíceis "reformas estruturais" por parte dos devedores; e não havia mecanismos para forçar os bancos comerciais a aumentarem seus créditos, nem a forçá-los a "tomar algumas perdas", como Baker teria dito a Volcker.

Nos próprios países devedores, a recepção ao Plano Baker foi menos calorosa do que nos EUA. Por exemplo, a revista Veja publicou que a oferta de dinheiro novo por parte de Baker causou "rebuliço geral", mas ressalvou que "o dinheiro é novo, mas as regras para chegar a ele são as de sempre": "rezar pela cartilha do Fundo" e praticar políticas de fortalecimento da iniciativa privada. Assim, as medidas do Plano Baker "não significam, nem de longe, que o governo americano tenha passado a julgar dispensáveis os programas de ajuste prescritos para os devedores ou se disponha a aceitar, por parte deles, programas econômicos hostis aos interesses dos EUA" (Veja, 1985, p. 110).

Não surpreende, portanto, que, como instrumento para fomentar o crescimento dos países devedores, o Plano Baker tenha fracassado totalmente. Os bancos continuaram a cobrar spreads elevados dos países devedores, a obter grandes lucros e, ao mesmo tempo, a reduzir sua exposição a estes países. Estes continuaram a enfrentar sérios obstáculos ao seu crescimento econômico e a registrar erosão nos níveis de vida de suas populações. Os conflitos entre devedores e credores nos processos de renegociação continuaram a se agravar, e o processo de renegociação do México - que por ser vizinho dos EUA encontrava-se em condição excepcionalmente favorável para lograr um acordo — demorou quase 14 meses, período no qual o país quase se viu obrigado a declarar moratória. Em resumo, a dinâmica interestatal não oferece explicação suficiente para as motivações e os objetivos do Plano Baker.

Uma explicação completa das razões do Plano Baker exige, portanto, uma análise do que ocorria na política doméstica dos EUA. No Congresso norte-americano, podemos observar um acirramento do debate em torno do déficit comercial, e uma maior disposição de propor soluções alternativas para a crise da dívida. O crescente ativismo do Congresso foi uma razão adicional para a iniciativa Baker, e oferece uma explicação melhor para o formato que o Plano adquiriu do que as explicações que se concentram em fatores externos. 


\subsection{A MOBILIZAC̣ÃO DO CONGRESSO}

No nível doméstico norte-americano, a preocupação com a dívida retornaria à pauta do Congresso por meio da discussão sobre a política comercial. O ano de 1984 foi marcado pela recuperação econômica que contribuiu para a reeleição de Reagan em novembro. Mas o otimismo criado por essa recuperação foi acompanhado pela preocupação crescente com a explosão do déficit comercial. Em 1984, a combinação de crescimento econômico com dólar forte levou o déficit ao maior valor já atingido até então nos EUA - cerca de US\$123,3 bilhões, quase o dobro dos US\$ 69,4 bilhões do ano anterior e o triplo dos US\$ 42,7 bilhões de 1982. O déficit no comércio com o Japão, isoladamente, atingiu US\$ 36,8 bilhões — um montante maior do que o total do déficit comercial norte-americano em 1980 (Auerbach, 1985).

Em um momento em que o desemprego atingia 8,4 milhões de trabalhadores, estimava-se que o déficit comercial sozinho custava cerca de 2,5 milhões de empregos à economia norte-americana. A despeito da recuperação econômica, o número de empregados no setor industrial em maio de 1984 era igual ao de 1970, cerca de 500 mil a menos do que em 1981 (Auerbach, 1984).

O crescimento do déficit comercial não chegou a comprometer a campanha de reeleição de Ronald Reagan, que obteria uma vitória fácil contra Walter Mondale em novembro a despeito da tentativa dos democratas de transformar a política comercial em bandeira de campanha (Shoch, 1998, p. 119). No Congresso, por outro lado, o déficit comercial foi motivo de críticas cada vez mais ásperas à política econômica do governo Reagan, tanto da parte de democratas quanto de republicanos. Em meio a avisos de que a perda de competitividade industrial era um "desastre" para a economia norte-americana e a propostas de criação de uma tarifa temporária para conter as importações, crescia entre os congressistas a visão de que seriam necessárias mudanças na política comercial para proteger as indústrias norte-americanas (Business Week, 1985a).

A maior parte dos críticos da política econômica do governo apontava, como causa para a explosão do déficit, a política monetária do Fed, que causara a supervalorização do dólar. Mas alguns críticos já começavam a relacionar as políticas monetária, fiscal e comercial norte-americanas com o problema da dívida externa dos países em desenvolvimento. Rudiger Dornbusch, por exemplo, já no início de 1984 criticava as barreiras comerciais a produtos exportados pelos países em desenvolvimento e apontava a 
inconsistência da política adotada para a crise da dívida com a política comercial norteamericana. Para corrigi-la, Dornbusch sugeria que o governo adotasse postura permeável a reduções de dívida (debt write-downs). "Não é do interesse nacional", afirmou Dornbusch em audiência, "insistir no pagamento completo [...] do serviço da dívida, e a insistência dos nossos formuladores de políticas nesta direção representa uma reação precipitada, e não uma busca consistente do interesse nacional" (U.S. Congress, 1984, pp. 62-63). Em audiência realizada pela Subcomissão de Comércio da Câmara dos Deputados em 28 de março para investigar as origens do déficit comercial, o "problema da dívida do Terceiro Mundo" foi apontado como uma possível causa da queda das exportações norte-americanas. A sobrevalorização do dólar foi apontada como a principal causa para o déficit comercial, mas a associação com a crise da dívida começou a aparecer. O presidente da Subcomissão, Sam Gibbons (democrata da Flórida), chegou a afirmar durante o depoimento do Representante de Comércio dos EUA, William Brock, que gostaria de ver "mais equilíbrio" na atuação do FMI. "Parece-me", afirmou Gibbons, "que os banqueiros, por causa do caráter de clube de seu setor e do medo que todo mundo tem que suas instituições entrem em colapso, foram ajudados, mas que as fazendas e fábricas dos Estados Unidos tiveram que ir mais longe em perdas de vendas e produção, e perda de empregos"xxviii (U.S. House, 1984c, p. 32).

Nesse momento começaram a ganhar visibilidade as propostas de alternativas para solucionar a crise. A rigor, as primeiras propostas neste sentido foram apresentadas por Felix Rohatyn em novembro de 1982 e por Peter Kenen de março de 1983. Ambos defendiam a criação de uma instituição internacional que compraria dos bancos as dívidas dos países em desenvolvimento com desconto sobre o valor de face e a seguir reestruturaria os débitos, oferecendo prazos mais longos e juros menores (Kenen, 1983, 1990). As propostas de Rohatyn e Kenen eram pouco detalhadas e, embora tenham obtido alguns apois importantes no Congresso (notadamente o senador Bill Bradley e o deputado Charles Schumer), não se mostraram alternativas politicamente viáveis à Estratégia dos Cinco Pontos (Rowen, 1983). A partir de 1984, porém, propostas de alternativas à abordagem do Tesouro para a crise da dívida passaram a ganhar mais visibilidade. Henry Wallich, do Fed, e H. J. Witteveen, exdiretor gerente do FMI, propuseram o estabelecimento de um seguro de crédito que reduziria a taxa de juros cobrada dos países devedores. Anthony Solomon, presidente do Fed de Nova York, propôs um teto para os pagamentos de juros. Também começaram a circular propostas de criar um fundo no FMI para subsidiar parte dos juros pagos pelos países mais pobres. Até 
mesmo Henry Kissinger voltou à carga contra a Estratégia dos Cinco Pontos e defendeu cortes nas taxas de juros e adoção de "prazos realistas" para o pagamento das dívidas. "Os bancos devem ser encorajados a deixar de lado a ficção de que o serviço total das dívidas é possível, e abandonar os contorcionismos necessários para manter este mito vivo", afirmou em artigo publicado no Washington Post Outlook (Rowen, 1984).

Com o início do segundo mandato de Ronald Reagan, em janeiro de 1985, James Baker trocou de lugar com Donald Regan e assumiu a direção do Departamento do Tesouro. Algumas mudanças se fizeram sentir de imediato. Ao contrário de Regan, um desafeto de Paul Volcker, Baker desenvolveu um bom relacionamento com o Presidente do Fed. Baker fez alterações no alto escalão do Tesouro e trouxe com sua nova equipe uma postura menos dogmática do que a prevalecente na gestão Regan (Roett, 1989, p. 63). Por fim, o novo secretário do Tesouro convenceu-se de que a possibilidade de redução do crescimento econômico - um resultado previsível do dólar forte e da perda de competitividade internacional dos EUA - representava ameaça para as perspectivas eleitorais do Partido Republicano nas eleições legislativas de novembro de 1986 (Shoch, 1998, p. 121).

A questão da política comercial ganharia centralidade na agenda política norteamericana a partir de meados de 1985. O déficit comercial se agravou no primeiro semestre do ano, subindo mês a mês e totalizando US\$ 70,7 bilhões até junho - 17,6\% a mais do que no primeiro semestre do ano anterior, quando o déficit já atingira a inédita marca de US\$ 60,1 bilhões (Seaberry, 1985, Business Week, 1985b). Percebendo que o governo Reagan estava politicamente vulnerável neste tema, o Partido Democrata adotou a estratégia de elevar a importância da política comercial no debate político. Ao mesmo tempo, procurou retirar a questão do âmbito local e transferi-la para o âmbito nacional. Ou seja, em vez de seguir sua política tradicional de ressaltar os efeitos prejudiciais da perda de competitividade comercial para determinados distritos, o Partido Democrata passou a enfatizar os benefícios de uma política comercial mais dura para o interesse nacional dos Estados Unidos como um todo (Shoch, 1998, pp. 124-125).

Seguindo esta estratégia, um grupo composto por três congressistas democratas de relevo apresentou, em julho, projeto de lei que criava tarifas a produtos importados de Japão, Taiwan, Coréia do Sul e Brasil (Shoch, 1998, p. 120). Poucas semanas depois, em agosto, os democratas venceram uma eleição especial no Texas e conquistaram uma cadeira na Câmara que era ocupada há mais de um século pelos republicanos (Shoch, 1998, pp. 120-121). 
Em resposta à pressão democrata, a própria Casa Branca se viu forçada a assumir postura mais protecionista em política comercial. James Baker foi um dos principais proponentes da "virada protecionista" dentro do governo Reagan. No final de julho, o Conselho de Política Econômica, presidido por Baker, começou a trabalhar em um plano para modificar a política comercial do governo. O secretário do Tesouro também foi o responsável pela criação de um fundo de US\$ 300 milhões para subsidiar exportações, pela formação de uma força-tarefa para combater "práticas injustas de comércio" por parte dos parceiros, e pelo aumento do uso dos casos de retaliação comercial no âmbito da Seção 301 (Shoch, 1998, pp. 121, 123). O ativismo econômico governamental promovido por Baker culminou na realização, em 22 de setembro, da reunião ministerial do Hotel Plaza de Nova York, na qual os ministros do Tesouro e os presidentes dos bancos centrais de Alemanha Ocidental, EUA, França, Japão e Reino Unido concordaram em intervir no mercado cambial para desvalorizar o dólar e assim reduzir o déficit comercial norte-americano. (Henning e Destler, 1988, Kilborn, 1985, Rowen, 1985a).

O crescente conflito entre Executivo e Legislativo levava o governo a temer pela capacidade de os EUA liderararem a economia mundial. Este temor ficaria claro em uma entrevista concedida por James Baker ao Times de Londres em novembro. Na ocasião, Baker afirmou ser um secretário "ativista”, cuja ambição era reestabelecer a liderança norteamericana. “A conta pára aqui”, assegurou. Segundo ele, o maior obstáculo à liderança dos EUA era seu próprio conflito político interno. Referindo-se à necessidade de reduzir o déficit público norte-americano, Baker lamentou que "uma casa do Congresso é dominada pelo pensamento de um partido, a outra casa do Congresso é dominada por outro partido que pensa outra coisa, enquanto o Poder Executivo não aceita mudanças na receita orçamentária”. Esta situação, segundo ele, arriscava colocar os EUA em um "estado de impasse político" (Morris, 1985).

Nesse momento, já se associava, no Congresso, o déficit comercial norte-americano com a crise da dívida dos países em desenvolvimento. O impacto da crise sobre o comércio internacional dos EUA apareceria pela primeira vez no Congresso nas audiências realizadas pela Comissão Econômica Conjunta em 17, 21 e 24 de junho de 1985. Ao abrir a audiência, o presidente da comissão, deputado David Obey (democrata do Wisconsin), afirmou que

Não há dúvida de que o Congresso está cada vez mais consciente do impacto da economia global sobre nosso próprio bem-estar econômico. O aumento das importações, o baixo desempenho exportador dos EUA e o dólar pouco competitivo são todos tópicos de preocupação e atenção. 
Estranhamente, no entanto, os problemas econômicos domésticos associados à crise da dívida latino-americana foram na maior parte ignorados. O Japão se tornou o símbolo de todos os nossos problemas e frustrações comerciais. [...] Mas nossos problemas comerciais com a América Latina, em muitos aspectos, são equivalentes aos que enfrentamos com o Japão. Eles certamente se equivalem em termos de magnitude. [...] Em 1980, nosso superávit [com a região] foi de US $\$ 4,8$ bilhões. Isso se deteriorou e se tornou um déficit de US\$ 15,7 bilhões no ano passado, e que tende a piorar ${ }^{\text {xxix }}$. (U.S. Congress, 1985, pp. 1-2.)

Numa indicação da predisposição dos congressistas, foram convidados a depor na audiência economistas de universidades e representantes dos setores financeiro e industrial. F. Gerard Adams, da Universidade de Pensilvânia, apresentou estimativas segundo as quais o ajuste das economias da América Latina teria causado a perda de cerca de 800 mil empregos nos EUA, especialmente no setor industrial. John Stevenson, vice-presidente da J.I. Case (fabricante de equipamentos agrícolas e de construção civil), associou diretamente as medidas de austeridade adotadas pelos países da América Latina com a redução das exportações da empresa para estes países. Stevenson sugeriu que o governo norte-americano adotasse políticas monetária e fiscal que reduzissem os juros (de maneira a diminuir a carga da dívida sobre os países latinoamericanos), que aumentasse os recursos disponíveis para as agências de crédito à exportação (FCIA e Eximbank) e que mantivesse o apoio às instituições multilaterais (U.S. Congress, 1985, p. 66). John Richards, do Conselho das Indústrias de Engenharia e Construção Internacional, defendeu um aumento do apoio dos EUA às instituições multilaterais de desenvolvimento, em particular ao Banco Mundial. Karin Lissakers foi direto ao ponto e afirmou que a abordagem vigente "não constitui uma solução para crise da dívida" (ibidem, p. 150) e que transferia os custos para os países devedores e "para nossos próprios exportadores" (ibidem, p. 151). Contrastando com a visão dos depoentes ligados à academia e à indústria, John Petty, chairman do Marine Midland Banks, afirmou que o processo de ajuste foi necessário para corrigir "desequilíbrios", mas a recuperação econômica dos países devedores estava começando e, com ela, viria a recuperação das exportações norte-americanas.

A necessidade de crescimento dos países devedores também seria o tema central do depoimento do ex-presidente do Banco Mundial Robert McNamara perante a Subcomissão de Instituições Internacionais de Desenvolvimento e Finanças, realizado em 5 de setembro. Segundo McNamara, os países da América Latina tinham conseguido evitar o colapso financeiro, mas agora precisavam entrar em uma fase de crescimento sustentável. Tal fase só seria possível com a ajuda do Banco Mundial, pois esta instituição - ao contrário do FMI possuía os instrumentos necessários para orientar e financiar projetos de longo prazo (U.S. 
House, 1985b, p. 6). "Não há instituição no mundo melhor qualificada para aconselhar estas nações sobre como mover em direção ao crescimento sustentável de longo prazo do que o Banco Mundial", garantiu McNamara (ibidem, p. 28). McNamara propunha que o Banco assumisse o papel de promotor do crescimento dos países endividados, ajudando-os a superar a crise. Esta ênfase no crescimento seria do interesse dos próprios EUA: “ajudar a América Latina a expandir é criar empregos nos Estados Unidos", declarou (ibidem, p. 41).

Outro exemplo de mobilização do Congresso foi a audiência realizada nos dias 9 e 10 de outubro pela Comissão de Relações Exteriores do Senado. Para aumentar a visibilidade das discussões, a audiência foi realizada em São Francisco, de maneira a permitir que diversos acadêmicos e líderes empresariais californianos fossem ouvidos. O local também foi escolhido para homenagear o World Affairs Council de São Francisco, que nos dois anos anteriores realizara uma grande pesquisa sobre os impactos negativos da crise da dívida para a economia norte-americana. Esta pesquisa deu origem a um estudo que fora apresentado ao Congresso em maio. Ao abrir os debates, o Senador Charles Mathias (republicano de Maryland) afirmou que "há uma relação clara entre a dívida do Terceiro Mundo e a saúde da economia dos EUA" (U.S. Senate, 1985, p. 1). Segundo Jones, os EUA perderam 500 mil empregos por causa da crise da dívida e a consequente redução das exportações do país (p. 32). Fishlow, por sua vez, defendeu uma redução nos juros pagos pelos países endividados, para permitir-lhes aumentar suas importações.

\subsection{O PLANO BAKER}

Neste contexto político, a partir da primavera de 1985 altos funcionários do Tesouro e do Fed começaram a trabalhar em um plano cujo objetivo declarado era restaurar o crescimento dos países devedores. Além deste objetivo, o plano em gestação tinha o propósito não declarado de manter a iniciativa política no tocante à questão da dívida externa na órbita do Tesouro e do Fed, evitando que o Congresso viesse a obrigar o governo a adotar algumas das propostas de abordagens alternativas em circulação à Estratégia dos Cinco Pontos. Este fato é admitido pelo próprio Volcker em suas memórias do período:

Mas quando [Baker] refletiu sobre o problema, ele não foi mais capaz do que eu de imaginar uma forma de forçar os bancos a assumirem algumas perdas e ao mesmo tempo fazê-los continuar a emprestar dinheiro novo para apoiar a recuperação de seus devedores. Ele também não achou nada promissoras as alternativas grandiosas que alguns no Congresso estavam propondo [...]. Mas não dava para fugir do sentimento de cansaço e frustração, e do fato, mais importante, de que o crescimento e o desenvolvimento estavam estancados. Embora nós não gostássemos dos planos mais grandiosos, nós não podíamos 
vencê-los sem ter nada. Então colocamos nossas cabeças para trabalhar em conjunto ${ }^{\mathrm{xxx}}$. (Volcker e Gyohten, 1992, p. 213, grifos meus.)

Volcker adiantaria pessoalmente alguns elementos do plano em eventos públicos em maio e junho de 1985, inclusive em audiência perante a Comissão de Bancos, Finanças e Assuntos Urbanos da Câmara de Representantes (Payer, 1986, p. 660, U.S. House, 1985a). Em seus pronunciamentos, Volcker procurava responder às críticas à Estratégia dos Cinco Pontos propondo um papel mais relevante para o Banco Mundial na questão da dívida. Como veremos, esta idéia seria a única novidade relevante do plano apresentado no outono, e ainda assim serviria apenas para reforçar a estratégia já em andamento (Boughton, 2001, p. 418).

James Baker apresentou as linhas gerais de sua proposta na reunião do Comitê Interino do FMI, realizada em 6 de outubro de 1985 na Coréia do Sul ${ }^{71}$, e ofereceu maiores detalhes dois dias depois, no encontro dos governadores do FMI e do Banco Mundial. Em seu diagnótico, os três principais problemas que deveriam ser resolvidos eram (i) as dificuldades que os países devedores estavam enfrentando para ajustar suas economias, (ii) a fragmentação das diversas iniciativas de apoio dos países credores e das instituições multilaterais, e (iii) a redução nos empréstimos privados.

Para superar estes três problemas, Baker propunha um "Programa para o Crescimento Sustentável", formado por três componentes:

a) Os países devedores deveriam, com o apoio da comunidade financeira internacional, adotar reformas econômicas estruturais, de maneira a promover o crescimento e conter a inflação. Estas reformas incluiriam privatizações, políticas de supply-side para aumentar o nível de investimento, e maior abertura aos fluxos comerciais e financeiros internacinais.

b) O FMI continuaria a ter papel central, mas passaria a contar com o apoio dos bancos multilaterais de desenvolvimento, em particular o Banco Mundial, de maneira a promover políticas market friendly nos países devedores. O Banco Mundial e o Banco Interamericano de Desenvolvimento (BID) aumentariam seus desembolsos anuais para o grupo dos 15 países mais endividados (os "Baker 15") de US\$ 6 bilhões para cerca de US\$ 9 bilhões.

c) Os bancos privados deveriam aumentar seus empréstimos a estes países, de maneira a atingirem, nos três anos seguintes, o total de US\$ 20 bilhões em financiamento privado. 
Na sua reunião de 13 de novembro, o plano receberia oficialmente o "apoio muito amplo" do Conselho Executivo do Fundo, que decidiu apoiar diretamente o esforço de patrocinar o "ajuste voltado ao crescimento" proposto pela iniciativa de Baker, por meio de políticas de supply side similares às promovidas pelo governo Reagan. Por fim, no dia 2 de dezembro o Presidente do Banco Mundial, Alden W. Clausen, juntou-se ao coro e manifestou seu apoio por meio de uma declaração conjunta com Larosière (Boughton, 2001, pp. 422, 424).

Note-se, no episódio, o alinhamento quase perfeito do FMI às preferências do Departamento do Tesouro. A rigor, a única divergência entre as duas agências era o fato de que o Tesouro pretendia privilegiar 15 países com o Plano Baker, enquanto o Fundo não poderia fazer distinção entre seus Estados-membros (Boughton, 2001, p. 423). Do lado do Banco Mundial, por outro lado, o fato de ele ter manifestado seu apoio à iniciativa apenas três semanas depois do FMI (e quase dois meses depois do discurso de James Baker em Seul) parece indicar que a instituição não participou da formulação do Plano e que não estava tão alinhada às preferências do Tesouro quanto o Fundo.

O próprio Paul Volcker admite que "a retórica [do Plano] foi literalmente rascunhada no avião para a Coréia" (Volcker e Gyohten, 1992, p. 214), o que indica que houve pouca coordenação do Tesouro e do Fed com as instituições multilaterais. Segundo Boughton, o FMI foi "consultado" sobre o plano em gestação no Tesouro e no Fed no final do verão (2001, p. 418). A ausência de coordenação com o Banco Mundial é um sinal de que o Plano Baker era, acima de tudo, um discurso político. A própria ênfase no "crescimento sustentável" dos países devedores era pouco mais do que um elemento de retórica. Embora o objetivo público do Plano fosse "promover o crescimento sustentado" dos países devedores, uma análise mais detalhada evidencia que seus instrumentos eram muito limitados e claramente insuficientes do ponto de vista econômico. Do ponto de vista político, no entanto, o Plano se mostraria bem mais eficiente, como veremos.

As demandas do Plano Baker aos bancos credores eram bastante moderadas. A meta de US\$ 20 bilhões de financiamento privado representava um aumento de apenas 3\% na exposição dos bancos aos países em desenvolvimento, menos do que a inflação anual - o que significava que a exposição seria reduzida em termos reais. Ademais, este montante seria menor do que o total de US\$ 27 bilhões que os bancos multilaterais eram chamados a

\footnotetext{
${ }^{71}$ A íntegra do discurdo de Baker em Seul pode ser encontrada em Kuczynski (1988).
} 
contribuir nos três anos seguintes (Boughton, 2001, p. 419). A lógica subjacente era que o que estaria impedindo os bancos de manterem níveis adequados de financiamento era a dúvida quanto aos esforços de ajustes macroeconômicos dos países devedores. Por isso, o envolvimento dos bancos multilaterais era tido como essencial para convencer os credores privados de que os países devedores estariam de fato ajustando suas economias (Boughton, 2001, p. 422).

A grande novidade apresentada por Baker era a inclusão do Banco Mundial como um ator importante na gestão da crise da dívida. Afinal, caberia a esta instituição financiar as reformas estruturais voltadas a recuperar o crescimento sustentável dos países devedores. Como o Banco estivera, até então, afastado da gestão da crise, alguns analistas viram no Plano Baker um enfraquecimento do FMI e, portanto, uma reversão na política adotada pelo Tesouro até então. Um exemplo dessa visão foi dado por Stanley Fischer, em audiência no Congresso em janeiro de 1986. Segundo ele, “o mais crucial [do Plano Baker, é que] ele retira a ênfase dos programas do FMI de redução de importações por meio de contração econômica, e enfatiza o crescimento de longo prazo" (U.S. Congress, 1986a, p. 31).

Essa visão se mostraria equivocada. O FMI foi claramente mantido como gestor da crise. A própria ocasião da apresentação do Plano - uma reunião do Comitê Interino do Fundo - deixava claro o apoio do governo norte-americano à manutenção de um papel protagônico para o FMI, e o diretor executivo norte-americano reiteraria este ponto na reunião do dia 13 de novembro (Boughton, 2001, p. 422). O Fundo manteria seu contato direto e privilegiado com os bancos credores, servindo como intermediário entre estes e os países devedores. O Banco Mundial assumiria uma posição subordinada ao FMI, pois a ajuda daquela instituição a um país devedor seria condicionada à assinatura de um acordo deste país com o Fundo - a quem caberia determinar a quantidade de recursos a ser fornecida pelos bancos multilaterais de desenvolvimento. Conforme afirmou o próprio secretário assistente para Assuntos Internacionais do Tesouro, David Mulford,

O que provavelmente vai acontecer é que o FMI negociará um programa. Esse exercício vai determinar as necessidades de financiamento para aquele país. E [o FMI] vai, juntamente com o país, tentar projetar como aquela diferença será financiada. Em outras palavras, quanto dela virá do Banco Mundial, quanto virá de saques do FMI, quanto virá do Banco Interamericano para o Desenvolvimento, e quanto virá dos bancos comerciais ${ }^{\text {xxi }}$. (U.S. Congress, 1986a, p. 46.)

Na prática, o papel do Banco Mundial era ser mais uma fonte de financiamento para a Estratégia dos Cinco Pontos, evitando que o governo norte-americano tivesse de voltar ao 
Congresso para pedir mais recursos. Se, em 1983, o governo teve de enfrentar uma dura batalha legislativa para aprovar o aumento de capital do FMI apesar de o sistema bancário norte-americano estar em risco, seria previsível que, em 1986, num momento político marcado por déficits comerciais, perda de empregos e insatisfação com os lucros dos bancos, a batalha fosse ainda mais dura. Neste contexto, os recursos Banco Mundial permitiriam ao governo continuar com a Estratégia dos Cinco Pontos sem precisar passar pelo Congresso. De fato, o Banco dispunha de tantos recursos que sua inclusão no Plano Baker viria a permitir ao governo norte-americano até mesmo adiar o aumento de capital do FMI marcado para 1988, e assim, mais uma vez, deixar de submeter ao Congresso sua abordagem para a crise da dívida.

Desta forma, a inclusão do Banco Mundial no Plano Baker colaborou para fortalecer a autonomia do Tesouro, conformar o FMI como gestor da crise financeira e manter o Congresso fora do processo.

Uma questão a ser respondida é por que o Banco Mundial não foi mobilizado pelo governo norte-americano já em 1982. A resposta está no relacionamento do Tesouro com o Banco. Se, em 1982, o governo norte-americano alimentava desconfianças com relação à atuação do Banco, em 1985 ele já estava devidamente "domado" e alinhado às preferências do Tesouro. Desta forma, tornou-se um agente confiável a quem o Tesouro poderia delegar uma tarefa na gestão da crise. O próximo tópico desenvolve este argumento.

\subsubsection{BANCO MUNDial: PROTAgONISTA OU COADJUVANTE?}

O Banco Internacional para Reconstrução e Desenvolvimento (BIRD), também conhecido como Banco Mundial, foi, junto como o FMI, criado na Conferência de Bretton Woods. Enquanto o objetivo do Fundo Monetário Internacional era a estabilização de curto prazo, o Banco Mundial voltava-se para o financiamento de projetos de longo prazo, tanto de reconstrução das economias afetadas pela guerra, quanto de desenvolvimento de economias atrasadas.

O Banco Mundial foi uma materialização da visão predominante em Bretton Woods sobre o papel dos Estados e a importância de cooperação internacional para o desenvolvimento. Como afirmam Gavin e Rodrik, enquanto a necessidade de os Estados manterem a estabilidade do sistema monetário internacional era evidente, era muito menos óbvia a necessidade de uma instituição multilateral que canalizasse capitais de áreas onde fossem abundantes para áreas fossem necessários para reconstrução e desenvolvimento (1995, 
p. 329). De fato, em virtude do que significou como inovação em termos de pensamento e prática econômica, “o Banco Mundial [...] pode ser visto como o mais impressionante dos monumentos institucionais à visão que guiou o sistema de Bretton Woods" (ibidem).

Assim como ocorrera com o FMI, as circunstâncias nas quais o Banco Mundial foi criado o colocaram sob virtual controle dos EUA. Sua sede também foi instalada em Washington, colocando-o sob a influência direta e cotidiana do governo norte-americano. Por uma regra não escrita, seu presidente seria sempre um norte-americano, ao passo que o diretor gerente do Fundo seria sempre um europeu.

Respondendo a constituencies diferentes no governo norte-americano, o Fundo e o Banco se afastariam nos anos posteriores a Bretton Woods. O Fundo, supervisionado diretamente pelo Departamento do Tesouro, em poucos anos passou a ser regido por uma visão ortodoxa, da qual seus mecanismos de condicionalidades para a realização de empréstimos representam seu maior exemplo. O Banco, por seu turno, com os anos ficaria mais ligado ao Departamento de Estado e se afastaria do pensamento econômico neoclássico, tornando-se, até o começo dos anos 80, uma das agências mais permeáveis à abordagem da Economia do Desenvolvimento (Bresser Pereira, 1995, pp. 216-217).

Como os países em desenvolvimento geralmente careciam não apenas de recursos materais, mas também da expertise necessária para aplicá-los, o Banco se tornaria também um fornecedor de idéias para estes países. Por isso, como mostram Gavin e Rodrik, “desde meados dos anos 60 o nome do Banco tem sempre sido associado com um conjunto particular de idéias sobre quais são as prioridades de desenvolvimento para os países pobres" (1995, p. 332). A atuação do Banco se fundamentaria na idéia de que a industrialização de uma economia não resulta de esforços graduais ou incrementais. Ao contrário, o desenvolvimento econômico é um processo histórico, sujeito a saltos e descontinuidades. Por isso, para que ele ocorra em países subdesenvolvidos, faz-se necessário um impulso inicial, um "grande empurrão" que leve uma economia agrária a montar uma estrutura industrial com dimensão suficiente para se auto-sustentar e crescer (Bresser Pereira, 1995, p. 216).

A partir da presidência de Robert McNamara (que tomou posse em 1968 e só deixou o cargo em 1981), o Banco passaria a se dedicar também a iniciativas de combate direto à pobreza e de atendimento às "necessidades básicas", pois se percebia que as políticas de desenvolvimento tinham como efeito colateral um aumento da disparidade de renda e, em alguns casos, até mesmo a piora, em termos absolutos, do nível de vida de camadas sociais 
menos favorecidas (Hirchman, 1981, p. 22). Neste sentido, ao final de 1980 o Banco aplicava cerca de $70 \%$ de seus recursos em operações de desenvolvimento rural (Farnsworth, 1980). McNamara também expandiu consideravelmente as operações do Banco: em 1967, a instituição possuía 767 funcionários e realizou 60 operações de empréstimo, totalizando US\$ 954 bilhões; em 1980, o Banco tinha crescido para 2.400 funcionários e realizou cerca de 250 operações, totalizando US\$11,7 bilhões (Rowen, 1980).

A vitória de Ronald Reagan, em 1980, marcaria o início do fim da hegemonia da Economia do Desenvolvimento sobre o Banco Mundial. Com Reagan, o grupo de conservadores da supply side economics chegou ao poder e assumiu o comando da política econômica dos Estados Unidos.

Para os supply-siders, o Banco Mundial era um instrumento de transferência de recursos dos países ricos para Estados intervencionistas e ineficientes do Terceiro Mundo. Os conservadores opunham-se com fervor particular à reorientação empreendida por McNamara para atender às "necessidades básicas", vista como um exercício de experimentação social (Rowen, 1981b). Um exemplo desta visão está presente no artigo de Jude Wanniski (que cunhou o termo supply-side economics) publicado na revista conservadora American Spectator em dezembro de 1980. No texto, Wanniski afirma que "o FMI e o Banco Mundial são dirigidos pelos money-center banks", e que "o objetivo do Banco Mundial é espremer o contribuinte dos EUA para obter recursos para o Terceiro Mundo". Acusando o Banco de adotar um modelo de desenvolvimento errado, Wanniski propôs que o novo presidente, "desde o início de seu governo, dê forma uma política externa que tenha como ingredientechave a transmissão de reformas econômicas neoclássicas para o resto do mundo". David Stockman, que foi presidente do Office of Management and Budget entre janeiro de 1980 e agosto de 1985, oferece em seu livro The triumph of politics (1986) outro exemplo da postura dos supply siders com relação às instituições de ajuda internacional para o desenvolvimento:

Tanto [o Senador Phil] Gramm quanto eu acreditávamos que os organismos de ajuda internacional e de suposto desenvolvimento do Terceiro Mundo - a ONU, os bancos multilaterais, e a USAID - estavam infestados de engano socialista. A burocracia da ajuda internacional estava transformando países do Terceiro Mundo em pântanos de ineficiência auto-imposta e enterrando-os sob montanhas de dívida externa que eles nunca seriam capazes de pagar ${ }^{\text {xxxii }}$. (Stockman, 1986, pp. 126-127.)

Em junho de 1980, talvez percebendo a derrota iminente de Jimmy Carter nas eleições presidenciais, Robert McNamara anunciou sua intenção de renunciar à presidência do Banco Mundial no ano seguinte, embora seu mandato durasse até abril de 1983. Ao anunciar que 
renunciaria, McNamara insinuou que seria melhor para o Banco se o próximo presidente fosse escolhido por um "comitê de seleção" e que ele não deveria necessariamente ser norteamericano (Cowan, 1980). McNamara temia, acima de tudo, que o governo seguinte indicasse o conservador William Simon como seu sucessor. Simon fora secretário do Tesouro do governo Ford e, durante seu mandato, opôs-se ferozmente à expansão das operações do Banco empreendida por McNamara (Rowen, 1980) ${ }^{72}$. Em novembro do mesmo ano, o governo norte-americano anunciou a escolha de Alden W. Clausen, presidente do Bank of America, então o maior banco dos EUA. Antes de indicar Clausen, o ainda presidente Carter consultou o presidente-eleito Ronald Reagan, que aprovou a escolha.

A despeito da aprovação de Reagan, a indicação de Clausen causou um "choque" no movimento conservador (Wanniski, 1980). Clausen contou com o apoio de George Shultz, um republicano moderado que fora secretário do Tesouro durante o governo Richard Nixon e que, em 1980, era executivo da Bechtel Corporation. Segundo Wanniski (1980), a Bechtel era "virtualmente uma extensão, o braço operativo dos bancos internacionais" no Terceiro Mundo. Os supply-siders imediatamente se opuseram à escolha de Clausen, considerado mais um integrante da "elite do Leste" que geria o Banco Mundial em proveito próprio.

A oposição do movimento conservador custaria a Clausen quatro anos de conflitos constantes com o governo Reagan. Em 1981, o subsecretário do Tesouro Beryl Sprinkel acusou o Banco de "encorajar o socialismo, a manipulação de preços e os sistemas econômicos que são incompatíveis com o nosso" (Glynn e Ma, 1981). Entre as autoridades do governo, circulou um documento, atribuído a Sprinkel, no qual se recomendava que os EUA deveriam ameaçar retirar seu apoio financeiro como forma de forçar o Banco a assumir políticas mais conservadoras (ibidem). Uma proposta, apresentada em 1980 por McNamara, de criação de um fundo de aproximadamente US\$ 30 bilhões, administrado pelo Banco, com o objetivo de incentivar a exploração de carvão, petróleo e gás em países em desenvolvimento foi vetada pelo novo governo (Farnsworth, 1981a).

A oposição do governo ao Banco Mundial resultou em diversos cortes de recursos, inclusive para programas aprovados ainda no governo Carter. Num sinal da mudança no clima político em Washington, o vice-secretário do Tesouro R. T. McNamar afirmou publicamente, perante a subcomissão de Instituições Multilaterais de Desenvolvimento da Câmara, estar empreendendo uma revisão do custo-benefício da participação dos EUA em bancos

\footnotetext{
${ }^{72}$ Simon também ficou famoso por tentar impedir a ajuda federal à cidade de Nova York em 1975 — o que
} 
multilaterais de desenvolvimento, para determinar se estas instituições efetivamente serviam aos interesses norte-americanos. Segundo McNamar, um dos objetivos da revisão era determinar se os bancos multilaterais "estão tão preocupados com direitos humanos quando se trata dos déspotas de esquerda quanto eles parecem estar quando lidam com os déspotas de direita" (Rowen, 1981a). Em 1981, David Stockman, no comando do Escritório de Administração e Orçamento, propôs um corte de $45 \%$ no orçamento de ajuda internacional para o desenvolvimento. A iniciativa provocou uma reação feroz do Departamento de Estado, que conseguiu impedir os cortes nos programas bilaterais - mas não nos multilaterais (Stockman, 1986, pp. 127-130). Como resultado, os US\$3,2 bilhões prometidos por Carter para a International Development Agency foram retidos.

Clausen, a princípio, não tentou esconder suas diferenças com relação ao governo Reagan. Em diversos pronunciamentos públicos, procurou desfazer os "equívocos" que haviam se difundido sobre o Banco, reiterando que a instituição não visava a redistribuir renda. "[O Banco] não é o Robin Hood do sistema financeiro internacional, nem a United Way da comunidade de desenvolvimento", afirmou (Farnswoth, 1982a).

Enquanto Clausen opunha-se publicamente aos supply-siders, Jacques de Larosière soube aproximar-se deles, enfatizando a necessidade de controlar a inflação em nível mundial. Na reunião anual do FMI e do Banco Mundial de setembro de 1981, Larosière declarou que "o estado presente do mundo impõe disciplina igualmente sobre países desenvolvidos e em desenvolvimento" (Farnsworth, 1981b). Era a mensagem oposta à de Clausen. Desta forma, Larosière procurou mostrar que as preferências do FMI estavam alinhadas com as do Tesouro. Esta percepção de alinhamento de preferências seria fundamental no segundo semestre de 1982, pois permitiu que o Tesouro decidisse delegar a gestão da crise da dívida ao Fundo.

Posteriormente, Clausen também procuraria aproximar o Banco Mundial das preferências do governo Reagan. Sua principal iniciatia neste sentido foi a consolidação do programa de Empréstimos para Ajustes Estruturais (Structural Adjustment Lending or SAL), criado em 1980, ainda na presidência de McNamara. O programa SAL representou a primeira tentativa do Banco de fomentar expressamente reformas institucionais e de políticas públicas, de forma a tratar as causas profundas dos déficits em balança de pagamento dos países em desenvolvimento $^{73}$. Cada operação no âmbito no programa envolvia três ou quatro operações individuais de financiamento, com duração de cinco ou seis anos. $\mathrm{O}$ desembolso dos fundos 
era dividido entre diversas fatias (tranches), condicionadas ao atingimento de metas expressas em termos de reformas institucionais a serem executadas pelo país que recebe os recursos (Please, 1984, pp. 86-87). Desta forma, o Banco Mundial passou a atuar paralelamente com o FMI - que desde 1974 possuía o programa Extended Fund Facility — no financiamento de ajustes estruturais dos países em desenvolvimento, com programas que apoiavam reformas macro e microeconômicas (Feinberg, 1988, p. 549). Ao mesmo tempo, os empréstimos setorais do Banco passaram a ficar crescentemente sujeitos ao que Feinberg denomina de "condicionalidade cruzada consultiva" - na qual uma operação do Banco é condicionada à existência de um programa de estabilização acordado entre o país tomador do empréstimo e o FMI - e ao que denomina de "condicionalidade cruzada interdependente", no qual as duas organizações aplicam os mesmos critérios para aprovar operações de financiamento, embora tenham propósitos diferentes - por exemplo, a exigência pelo Banco de que o país tomador adotasse uma taxa de câmbio "realista" como condição para fechar um empréstimo setorial. Desta forma, sob Clausen o Banco Mundial permitiu o aumento da influência do Fundo Monetário Internacional sobre suas decisões, o que, no contexto da crise da dívida, aproximou o Banco das preferências do Tesouro norte-americano (Feinberg, 1988, pp. 552-556).

Mesmo assim - e confirmando a asserção teórica de que a melhor forma de controlar um agente é selecionar indivíduos com preferências similares às do principal —, a partir de meados de 1984 começaram a circular rumores de que Clausen não obteria o apoio norteamericano para um novo mandato, e que seria substituído por alguém mais ligado aos conservadores. O sinal mais evidente de desprestígio de Clausen foi o fato de que, durante a preparação do Plano Baker, ele não foi consultado nenhuma vez — a despeito de defender, há meses, o aumento dos empréstimos oficiais aos países em desenvolvimento para ajudá-los a superar a estagnação econômica. Ao saber que Baker anunciaria uma iniciativa que enfatizaria a atuação do Banco Mundial sem tê-lo sequer consultado, Clausen decidiu deixar o Banco. Assim, na mesma reunião em Seul na qual Baker anunciou seu plano para os países devedores, Clausen anunciou que não tentaria reeleger-se para a presidência do Banco Mundial por mais um mandato (Rowen, 1985b). Posteriormente, o governo norte-americano indicaria o ex-deputado Barber Conable (republicano de Nova York) para substituir Clausen. Conable assumiria a presidência do Banco em julho de 1986.

\footnotetext{
${ }^{73}$ Para avaliações completas do programa SAL, cf. Helleiner (1986) e Mosley, Harrigan e Toye (1991).
} 
A queda de Clausen no mesmo momento em que Baker anunciava um novo papel para o Banco indicou que a ausência de protagonismo desta instituição até então se devia principalmente à oposição do próprio Departamento do Tesouro. A exemplo do FMI, o Banco dispunha de recursos financeiros, funcionários experientes e acesso aos governos dos países em desenvolvimento, além de contar com insulamento burocrático que lhe permitiria atuar na crise da dívida com mínima ingerência do Congresso. No entanto, não havia suficiente alinhamento de preferências entre o Tesouro e o Banco, o que se refletiu no conflito entre Clausen e diversas autoridades norte-americanas. O papel irrelevante do Banco desde 1982 demonstra que o Tesouro, ao delegar a gestão da crise da dívida, selecionou o agente cujas preferências mais se aproximavam das suas — neste caso, o FMI.

Em retrospectiva, também é possível afirmar que a saída de Clausen não foi suficiente para conferir ao Banco Mundial um papel protagônico na crise da dívida. Como vimos, o Plano Baker foi estruturado de forma a manter o FMI como gestor da crise. Ao Banco Mundial, coube um papel auxiliar, aumentando os recursos públicos à disposição de maneira a permitir que os bancos continuassem a reduzir sua exposição. O governo norte-americano sequer precisou solicitar um aumento imediato de capital do Banco, o que teria exigido a aprovação do Congresso e teria tornado mais agudo um conflito político que já se anunciava entre Executivo e Legislativo. Ao contrário, Baker deixou muito claro desde o começo que não pediria fundos adicionais para o Banco Mundial no Congresso (cf. infra, p. 184, CG Weekly Online, 1985).

\subsection{RESULTADOS: O CONGRESSO E O PLANO BAKER}

No nível externo aos EUA, o Plano Baker foi muito pouco significante. Do ponto de vista econômico, o Plano não logrou aumentar os empréstimos dos bancos privados, nem fomentar políticas de crescimento nos países devedores. Estes continuaram a enfrentar estagnação econômica, inflação elevada, queda dos níveis de vida e instabilidade política. Mesmo do ponto de vista político, o Plano Baker não foi suficiente para reduzir a percepção dos países devedores de que a abordagem defendida pelo Tesouro não era suficiente, e que seria necessário buscar abordagens alternativas para superar a crise. 


\subsubsection{NÍVEL EXTERNO: RESULTADOS DECEPCIONANTES E NOVA CRISE DO MÉXICO}

Do ponto de vista econômico, como ferramenta para superar a crise da dívida, os resultados do Plano Baker foram decepcionantes. Apesar da retórica em prol da retomada do crescimento dos países devedores, os principais beneficiários do Plano foram os bancos credores, que lograram reduzir ainda mais seus créditos aos países em desenvolvimento. $\mathrm{O}$ fracasso econômico foi evidente até mesmo nos termos do próprio Plano Baker. Embora tivesse sido estabelecida a meta de aumentar em US\$20 bilhões os créditos dos bancos comerciais aos 15 principais países devedores, o monitoramento do próprio FMI verificou que, desde o início do Plano Baker, os bancos receberam mais recursos a título de juros e amortizações do que concederam em novos empréstimos. Segundo a edição de 1989 do World Economic Outlook, em 1986 os países devedores transferiram US\$ 1,6 bilhão aos bancos credores (Boughton, 2001, p. 428). Como os países devedores continuaram a depender de grandes volumes de financiamento externo, os bancos multilaterais ocuparam o espaço deixado pelos bancos comerciais e passaram a responder por uma fatia maior da oferta de crédito. Nos três anos seguintes, estas instituições multilaterais emprestaram US\$ 24 bilhões aos países em desenvolvimento, quase atingindo a meta de US\$ 27 bilhões determinada pelo Plano Baker (Boughton, 2001, p. 427).

Embora Larosière manifestasse apoio público ao Plano, o próprio staff do FMI mostrava-se cético. Os funcionários do FMI reconheciam que o Plano Baker necessitaria de mais apoio da parte dos países credores, por meio de flexibilidade na regulação de instituições financeiras, aumento nos créditos à exportação dos países devedores, redução do protecionismo e redução dos déficits fiscais (Boughton, 2001, p. 424). A principal falha da lógica econômica do Plano era a ausência de quaisquer mecanismos de incentivo ou punição que levassem os bancos comerciais a ampliarem seus créditos aos países em desenvolvimento. De fato, a iniciativa sequer dispunha de mecanismos para monitorar sua execução. Na ausência de tais mecanismos, o Plano Baker não passava de uma tentativa de convencer os bancos, com argumentos morais, a emprestar mais recursos. Como afirma Boughton, "a verdade era que o plano foi costurado com um tecido muito mais fino do que muitos observadores acreditavam" (2001, p. 425).

Não surpreende, portanto, que o Plano não tenha empolgado os países devedores. A adesão aos planos de "reformas estruturais" dos bancos multilaterais de desenvolvimento propostos no âmbito da iniciativa foi muito baixa. Para cumprir suas metas de ampliação de 
crédito, estes bancos aumentaram o financiamento de projetos de desenvolvimento tradicionais - o que é uma forma indireta de financiar déficits em balança de pagamentos. Às voltas com problemas prementes como inflação e instabilidade política, os governos dos países latinoamericanos preferiram manter a retórica contra a dívida a empreender planos politicamente difíceis e custosos de reformas econômicas de longo prazo. Assim, os devedores receberam o Plano com frieza e continuaram a protestar contra a injustiça representada pela abordagem vigente para a crise da dívida sem, contudo, tomarem medidas mais agressivas. Sinal de que o comportamento dos devedores pouco foi alterado é o fato de que as conferências realizadas no âmbito do Consenso de Cartagena depois do anúncio do Plano Baker - Montevidéu em dezembro de 1985 e Punta del Este em fevereiro de 1986 apenas repetiram o padrão dos encontros anteriores, marcadas por retórica acalorada mas fraca coordenação entre os países devedores (Kuczynski, 1988, pp. 148, 151).

O Plano Baker mostraria sua insuficiência como abordagem para a crise da dívida já em seu primeiro teste, representado pela renegociação de um acordo com o México a partir de outubro de $1985^{74}$. O México e o FMI negociaram durante vários meses, mas não chegavam a um acordo porque o FMI exigia uma redução do déficit público que o governo mexicano julgava impossível alcançar. Entre dezembro de 1985 e abril de 1986, o governo tentou reduzir o déficit público pela metade cortando gastos. Mas o preço do petróleo caiu, a receita de exportação de petróleo reduziu-se mais do que foi economizado com os cortes de gastos, e o déficit público subiu ainda mais. Em junho, as reservas internacionais do país atingiram o periogoso nível de US\$ 3,2 bilhões - US\$ 1,5 bilhão a menos do que no final de 1985 e US\$ 4,1 bilhões a menos do que no final de $1984^{75}$. Neste mês, Paul Volcker envolveu-se pessoalmente nas negociações, chegando mesmo a viajar para a Cidade do México para reunir-se com o presidente Miguel de La Madrid e tentar convencê-lo - sem muito sucesso - a aceitar as condições exigidas pelo FMI. Em 17 de junho, o ministro da Fazenda, Silva Herzog, renunciou. Foi imediatamente substituído por Gustavo Petricioli.

Petricioli encontrou-se com Larosière na sede do FMI em 11 de julho para informar que as reservas mexicanas caíam em ritmo tão acelerado que o país não podia mais se dar ao luxo de continuar negociando. Como o governo não conseguiria lograr a redução de gastos públicos exigida pelo Fundo, o México seria obrigado a anunciar uma moratória de sua dívida. A jogada de Petricioli funcionou: dois dias depois, Larosière apresentou-lhe uma

\footnotetext{
${ }^{74}$ A narrativa do acordo com o México se baseia em Boughton (2001, pp. 437-448).
} 
proposta inovadora, na qual as metas de déficit público estavam ligadas ao preço do petróleo. Nos termos do acordo final, o México receberia um empréstimo de DES 1,4 bilhão (cerca de US\$ 1,7 bilhão), mais uma linha de crédito de DES 800 milhões a ser sacada se o preço do petróleo caísse abaixo de US\$ 9,00/barril.

O financiamento do FMI seria complementado com um empréstimo de US\$ 1,4 bilhão do Banco Mundial, com um empréstimo do Export-Import bank negociado com o Tesouro norte-americano, e com um grande pacote de empréstimos oficiais bilaterais intermediados pelo BIS. O pacote assemelhava-se ao pacote costurado entre agosto e setembro de 1982.

A presteza dos credores oficiais para oferecer recursos ao México não se repetiu entre os bancos comerciais. Para liberar seu empréstimo ao México, o FMI exigia que os bancos aportassem pelo menos US\$ 6 bilhões em "dinheiro novo". As negociações entre o México e o comitê de credores começaram em agosto. Por ocasião do encontro anual do FMI e do Banco Mundial, realizado em 30 de setembro em Washington, um acordo ainda parecia distante. As partes se reuniram no mesmo hotel em que ocorria o encontro do Fundo e do Banco, e a elas se juntaram Volcker, Conable e Larosière. Com a ajuda destas autoridades, as partes gradativamente se aproximaram e, quando o único ponto de discórdia era a taxa de juros a ser cobrada pela operação, Volcker convenceu-os a repartir a diferença e fechar um acordo (Volcker e Gyohten, 1992, p. 215). A despeito do acordo fechado com o Comitê Consultivo, somente no final de novembro o México obteve o montante de recursos privados de que precisava para finalizar o acordo com o Fundo.

O longo e difícil processo de renegociação enfrentado pelo México entre outubro de 1985 e novembro de 1986 ilustra o fracasso do Plano Baker como ferramenta de coordenação financeira. A atitude reticente dos bancos comerciais não se alterou, nem sua rejeição a qualquer forma de redução ou capitalização dos juros diminuiu. O FMI continuou como gerente da crise, conferindo ao Banco Mundial papel secundário, de meramente usar seus fundos para complementar os pacotes de créditos oficiais. O prometido crescimento econômico dos países devedores não se materializou, e as renegociações das dívidas continuaram a emperrar em pontos como a dimensão do déficit público e os spreads cobrados pelos bancos. Por isso, como afirmou Volcker, “o Plano Baker já estava com problemas na primavera de 1987; qualquer sentimento de entusiasmo já tinha acabado" (Volcker e Gyohten, 1992, p. 215).

\footnotetext{
${ }^{75}$ No final de 1984, as reservas do México somavam US\$ 7,3 bilhões. Um ano depois, eram de US\$ 4,7 bilhões.
} 


\subsubsection{NÍVEL DOMÉSTICO: SUCESSO EM CAPTURAR A INICIATIVA POLÍTICA}

Se, no nível externo, o Plano Baker rapidamente mostrou-se insuficiente, no nível doméstico norte-americano ele foi muito mais relevante. Com seu discurso centrado no “crescimento sustentável” dos países devedores, o Plano pareceu uma resposta às críticas que vinham sendo feitas por setores da sociedade e do Congresso contra a estratégia vigente para a crise da dívida. Desta forma, o Plano permitiu que o Tesouro parecesse estar tomando medidas inovadoras para encerrar a crise, servindo assim para esvaziar as críticas de que o governo aferrava-se teimosamente a uma estratégia falha apenas para ajudar os bancos. Desta forma, o Plano Baker servia como sobrevida para a Estratégia dos Cinco Pontos, cuja lógica era justamente fornecer aos grandes bancos tempo suficiente para que reduzissem gradativamente suas exposições aos países em desenvolvimento.

Além disso, o Plano Baker permitiu que o Tesouro lograsse manter a iniciativa política sobre o problema, impedindo que outros atores ganhassem espaço. Como afirma Whitehead, "quase tudo que foi feito para os devedores pelo Ocidente desde outubro de 1985 pode ser atribuído ao "Plano Baker'” (1989, p. 139). De fato, o debate político nos EUA em torno da crise da dívida seria dominado, nos meses seguintes, por avaliações e análises do Plano Baker. Um exemplo é o artigo de Robert Hormats, então executivo da Goldman Sachs, no último número da Foreign Affairs em 1985:

O Plano Baker finalmente colocou os Estados Unidos do lado certo do tema. Ao reconhecer que a crise da dívida tinha se transformado em uma crise de desenvolvimento, e ao ressaltar a importância de reviver o crescimento e pressionar pelo aumento dos empréstimos, ele melhorou a credibilidade dos EUA com as nações devedoras. Ao enfatizar a necessidade de aperfeiçoamento das políticas daquelas nações, ele tratou de um grande imperativo econômico e de uma preocupação legítima dos credores. E ao sublinhar a necessidade de os países endividados ganharem confiança suficiente do setor privado para reverter a fuga de capitais - que nos últimos anos era extremamente grande na Venezuela, no México e na Argentina - ele tratou de uma preocupação particular do Congresso, o qual considera difícil justificar programas de apoio a países cujos próprios cidadãos estão mandando seu capital para fora. (1985, p. 474.)

Estes efeitos do Plano puderam ser sentidos particularmente no Congresso. A partir do discurso de James Baker em Seul em outubro de 1985, quase todas as discussões no âmbito das comissões legislativas se concentrariam em avaliar o Plano Baker e sua execução ${ }^{76}$.

Em 22 de outubro — apenas duas semanas depois do anúncio em Seul — James Baker defendeu o Plano Baker em depoimento perante a Comissão de Bancos, Finanças e Assuntos 
Urbanos da Câmara dos Deputados. O presidente da comissão, Fernand St. Germain (democrata de Rhode Island) abriu os debates com um discurso duro, em termos similares aos que marcaram, dois anos antes, os debates relativos ao aumento do capital do FMI:

O governo irá pedir a ajuda do Congresso para executar seu plano de envolver-se ativamente na crise da dívida internacional? As propostas contidas no "Programa para o Desenvolvimento Sustentável" irão requerer a autorização e a alocação de recursos adicionais dos EUA - particularmente para o Banco Mundial, se não também para o FMI?

Se assim for, eu e muitos outros devemos ser convencidos de sua necessidade.

Sr. Secretário, o senhor estava na Casa Branca em 1983, quando logramos aprovar a lei de financiamento do FMI por apenas seis votos. [...] Para refrescar sua memória, muitos membros do Congresso não conseguiam entender - e ainda não conseguem - como que um programa de austeridade imposto pelo FMI aos países menos desenvolvidos poderia aumentar as exportações dos EUA para esses países. [...]

Sr. Secretário, muitos membros do Congresso, tanto de dentro quanto de fora da comunidade financeira, rotularam a última lei do FMI [...] como um salvamento para os grandes bancos ${ }^{\mathrm{xxxiii}}$. (U.S. House, 1985c, pp. 1-2).

O deputado Frank Annunzio (democrata de Illinois) foi ainda mais duro:

Antes de continuar, permita-me declarar que me oponho a qualquer contribuição adicional ao Banco Mundial ou ao FMI por parte do governo dos EUA.

Em um momento no qual os EUA apresentam déficits recordes e a dívida interna transborda acima de US\$ 2 trilhões, como podemos entregar US\$ 2 bilhões para o Banco Mundial? Como o governo pode propor um orçamento equilibrado até 1991 e gritar contra o excesso de gastos quando ele quer dar US\$ 2 bilhões para o Banco Mundial?

E deve ser ótimo para os agricultores em dificuldades, aos quais o governo disse que não vai salvá-los, saber que nos últimos quatro anos o Banco Mundial aumentou em $400 \%$ seus empréstimos para países comunistas. [...]

Os fundos dos EUA realmente são usados para o propósito original ou servem apenas para salvar os grandes bancos cujos empréstimos para outros países estão em default? Nós damos US\$ 200 milhões por ano para a Costa Rica e o que acontece com o dinheiro? Eis o que o presidente do banco central do país diz que acontece com o dinheiro. "Nós estamos reciclando dinheiro do governo dos EUA e usando-o para pagar os bancos dos EUA." [...]

Há um grupo neste país que está profundamente preocupado com as doações de dinheiro para países que ridicularizam os Estados Unidos. Esse grupo é chamado de contribuintes $^{\text {xxiv }}$. (U.S. House, 1985c, pp. 6-7).

Em sua apresentação, James Baker afirmou que a estratégia adotada até então para a crise da dívida lograra "progresso considerável”, mas que alguns "problemas" surgiram. O novo programa era uma iniciativa que modificava a estratégia em vigor para dar conta destes novos problemas. Deste ponto de vista, o Plano Baker foi apresentado como a "nova fase" da estratégia relativa à dívida.

\footnotetext{
${ }^{76}$ A exceção seria a audiência da Comissão Econômica Conjunta de 24 de junho, que será analisada no item seguinte, cujos participantes afirmaram considerar o Plano Baker mera continuação da estratégia em vigor desde 1982.
} 
Confrontado com congressistas relutantes em aprovar o uso de recursos públicos norte-americanos no problema da dívida, Baker procurou deixar claro que seu novo plano não exigiria aportes por parte dos EUA: "eu tive dois encontros com os bancos e com o presidente Volcker, e eu creio que deixei totalmente claro que não estamos falando de conceder garantias federais" (U.S. House, 1985c, p. 20). A questão quanto à necessidade de o governo federal aportar recursos para o Plano apareceu diversas vezes na audiência, e Baker repetidamente negou que pediria mais recursos ao Congresso. "Eu não estou aqui hoje pedindo dinheiro", respondeu Baker asperamente a uma pergunta de Frank Annunzio (p. 27). O dinheiro, explicou Baker, viria dos fundos disponíveis no Banco Mundial. "Não é necessário [utilizar recursos dos EUA] neste estágio porque há capacidade adicional de financiamento no Banco Mundial neste momento", admitiu Baker (p. 48). O uso dos recursos do Banco Mundial era uma forma conveniente de não ter de buscar aprovação do Plano Baker ao Congresso. Mas, segundo alegava o secretário do Tesouro, o que de fato motivava o uso da "capacidade ociosa" de financiamento do Banco - que até então fora relegado ao segundo plano — era sua capacidade de financiar programas de reformas econômicas estruturais (p. 26).

O depoimento de Baker evidencia que a tática do Tesouro ao lançar o Plano Baker era (i) assumir a existência de um problema e (ii) propor uma solução pretensamente nova que não necessitasse de autorização do Congresso. Desta forma, o Tesouro criava uma first mover advantage, pois o lançamento do novo programa tornava mais custoso, para o Congresso, tentar tomar a iniciativa e propor suas próprias soluções. Na ausência de tal programa, seria mais fácil para um grupo de congressistas propor e aprovar algum programa de alteração da estratégia em vigor, dado que a oposição a esta estratégia estava aumentando dentro da própria sociedade norte-americana. Ademais, a solução proposta pelo Plano Baker, embora envolvesse o uso de recursos do Banco Mundial, mantinha o FMI como principal gestor da relação entre países devedores e bancos credores, garantindo a continuidade das políticas de geração de superávits comerciais para reduzir gradativamente a exposição dos bancos.

A versão de que o Plano Baker era uma iniciativa nova ganhou curso no Congreso. Em 23 de janeiro de 1986, a Comissão Econômica Conjunta da Câmara e do Senado realizou audiência sobre o "problema da dívida". A audiência foi aberta pelo presidente da subcomissão de Objetivos Econômicos e Política Intergovernamental, deputado Lee Hamilton, com as seguintes palavras: 
Hoje, a Subcomissão de Objetivos Econômicos e Políticas Intergovernamentais da Comissão Econômica Conjunta examinará a implementação da iniciativa do governo para a dívida internacional, revelada pelo secretário Baker em outubro último em Seul. [...]

As iniciativas anunciadas pelo secretário Baker em Seul em outubro constituem uma importante mudança de curso na política do governo para o gerenciamento do problema da dívida $^{\mathrm{xxx}}$. (U.S. Congress, 1986a, p. 1, grifo meu.)

Note-se, neste caso, como o Plano Baker era apresentado como um conjunto de medidas inovadoras para o problema da crise da dívida - o que, como vimos, não era correto. A abordagem permanecia essencialmente a mesma: emprestar recursos públicos aos países devedores para permitir que os bancos comerciais reduzissem, ainda que lentamente, sua exposição a eles. O FMI continuou no comando das negociações com os países devedores, exigindo programas de austeridade que visavam a garantir que eles contiuariam a pagar juros e amortizações das dívidas.

A aparente promoção do Banco Mundial a um papel de protagonista na crise foi também importante como elemento da estratégia política do Tesouro. Por um lado, os críticos do FMI viram, nessa aparente elevação do perfil do Banco, uma admissão das autoridades norte-americanas das deficiências do Fundo e de sua incapacidade de gerenciar a crise. Por outro lado, como organização internacional, o Banco Mundial também estava imune às pressões diretas do nível doméstico norte-americano; desta forma, eventuais redirecionamentos que o Congresso quisesse promover em sua atuação teriam que ser intermediados pelo Tesouro e pelo diretor executivo dos EUA na instituição.

A importância do Plano Baker para manter o controle da iniciativa política no âmbito do Tesouro e do Fed ficaria ainda mais evidente a partir de meados de 1986, quando o Partido Democrata transformou a política comercial em bandeira de campanha e a associação entre déficit comercial e crise da dívida foi definitivamente introduzida no debate político norteamericano. O próximo tópico trata deste desdobramento.

\subsubsection{A ASSOCIAÇÃO ENTRE CRISE DA DÍVIDA E DÉFICIT COMERCIAL NO CONGRESSO}

Em 1986, o déficit comercial norte-americano continuou a crescer. Como parte de sua estratégia para as eleições legislativas de novembro, o Partido Democrata decidiu transformar a política comercial em bandeira de campanha, elevando-a a um dos principais pontos do debate político. Neste sentido, a liderança do partido procurou aumentar o escopo do debate, que tradicionalmente limita-se aos distritos industriais onde se concentra sua base eleitoral, 
para alcançar também eleitores independentes (swing voters). Isto foi feito enquadrando o tema de política comercial como um problema de interesse nacional norte-americano, e portanto de interesse do eleitorado em geral (Shoch, 1998, pp. 124-125). O tema de comércio internacional seria construído, pelos democratas, como um teste da "força" dos Estados Unidos. "Somos a favor da força americana", era o lema dos congressistas democratas (Shoch, 1998, p. 122).

Como parte deste enquadramento da política comercial como elemento do interesse nacional norte-americano, deputados democratas passaram a associar claramente o déficit comercial com a crise da dívida. $\mathrm{O}$ argumento era que a abordagem adotada pelo Tesouro para a dívida - que exigia que os países devedores reduzissem suas importações e aumentassem suas exportações - era uma das causas do déficit comercial dos EUA, pois reduzia a demanda dos produtos industriais norte-americanos e aumentava a oferta de produtos agrícolas.

A associação entre déficit comercial e crise da dívida foi articulada em um documento produzido pelo staff da Comissão Econômica Conjunta do Congresso ${ }^{77}$. Concluído em 10 de maio, o documento foi circulado pelo presidente da Comissão, Deputado David Obey (democrata de Wisconsin) a todos os congressistas democratas, e seu ponto central era que:

Estava claro desde o começo que o problema da dívida do Terceiro Mundo representava uma ameaça séria e potencialmente catastrófica para a estabilidade do sistema financeiro internacional. Até agora, a catástrofe financeira foi evitada, o que era o objetivo inicial dos formuladores da política. [...] Mas, ao mesmo tempo, esta política feriu seriamente - e desnecessariamente - o bem-estar econômico de outros setores da economia dos EUA, em particular a agricultura e a indústria ${ }^{\text {xxvi }}$. (U.S. Congress, 1986b, p. 18.)

O relatório então detalhava os prejuízos que a abordagem do Tesouro para a crise da dívida causou ao setor agrícola norte-americano. Como os países devedores tiveram de gerar grandes superávits comerciais, foram obrigados a reduzir suas importações e aumentar suas exportações. A redução das importações dos países devedores causou redução nas exportações dos Estados Unidos. De acordo com o documento, "aproximadamente 20 porcento do total do declínio das exportações agrícolas dos EUA [entre 1982 e 1985] foi resultado da queda de vendas para a América Latina” (U.S. Congress, 1986b, pp. 19-20). Outro impacto causado pela política promovida pelo Tesouro para a crise da dívida foi a acentuada queda do preço das commodities. Esta queda deveu-se ao fato de que os países

\footnotetext{
${ }^{77}$ Este documento foi anexado à transcrição da audiência da Comissão Econômica Conjunta do Congresso realizada em 24 de junho de 1986. Cf. U.S. Congress (1986b), pp. 14-59.
} 
devedores viram-se obrigados a aumentar suas vendas externas, causando excesso de oferta dos seus principais produtos de exportação. Segundo o relatório, os preços mundiais de açúcar, trigo, milho e soja eram menores em 1985 do que foram em 1982; em alguns casos, os preços encontravam-se no patamar mais baixo em 40 anos (ibidem, p. 21). Esta queda dos preços teria ocorrido a despeito da redução da produção destas commodities nos EUA. Segundo o relatório, enquanto a produção norte-americana caiu, "os países devedores em geral, e a Argentina e o Brasil em particular, expandiram muito sua produção, [...] e suas exportações aumentaram ainda mais rapidamente do que a produção" (ibidem, p. 27).

Como conseqüência desta política, milhares de produtores rurais tinham ido à falência, assim como centenas de bancos agrícolas (farm banks) norte-americanos. Segundo o relatório, entre 1982 e $198550 \%$ das falências bancárias foram de farm banks, embora estas instituições correspondessem a apenas $25 \%$ do total de bancos em operação no país. Isto indicava um problema de fundo no setor agrícola, causado, em grande medida, pela política do Tesouro para a crise da dívida (U.S. Congress, 1986b, p. 28).

O documento, por fim, avisava que o Plano Baker poderia promover uma erosão ainda maior das exportações norte-americanas, agravando a crise nos setores produtivos. Um empréstimo de US\$ 350 milhões concedido à Argentina pelo Banco Mundial era apresentado como exemplo. Segundo o relatório, o empréstimo fora concedido sob a condição de que a Argentina reduzisse seu imposto de exportação sobre produtos agrícolas, o que aumentaria ainda mais as vendas argentinas, em detrimento dos produtores norte-americanos. "Quem vai comprar as exportações adicionais da Argentina?", perguntava o documento (U.S. Congress, 1986b, pp. 44-45).

Ainda no final de maio, em audiência perante a Comissão de Relações Exteriores do Senado, James Baker seria confrontado diversas vezes com os argumentos apresentados pelo documento da Comissão Econômica Conjunta. A todas as perguntas, Baker daria a mesma resposta: a abordagem adotada pelo Tesouro para a crise da dívida era, do ponto de vista dos produtores norte-americanos, a melhor das alternativas, pois um eventual default ou interrupção unilateral dos pagamentos de serviço da dívida excluiria qualquer país em desenvolvimento do mercado financeiro internacional, impossibilitando-o de importar. Segundo este argumento, as ações tomadas até então tinham permitido aos países em desenvolvimento continuar importando, embora em nível menor do que antes da crise. $\mathrm{O}$ Plano Baker seria o passo seguinte neste processo, pois, graças à participação do Banco 
Mundial, promoveria o crescimento dos países devedores e, assim, permitiria a eles aumentar suas importações (U.S. Senate, 1986). Ao se referir às reformas que os países devedores deveriam empreender no âmbito do novo plano, Baker afirmou que "não estamos falando dos mesmos tipos de medidas de austeridade que estávamos falando antes, em conexão com os programas do FMI". "Estamos falando em reformas econômicas orientadas para o crescimento", garantiu (U.S. Senate, 1986, pp. 14-15).

O mesmo documento seria discutido em maior profundidade em uma audiência realizada pela própria Comissão Econômica Conjunta em 24 de junho. Diferentemente do que ocorrera até então, as testemunhas desta audiência - nenhuma delas ligadas ao governo ou aos bancos credores - não consideravam que o Plano Baker representasse qualquer novidade na abordagem de gerenciamento da crise da dívida vigente desde 1982. As testemunhas também concordaram em que a forma como a crise vinha sendo enfrentada era boa para os bancos, mas péssima para os outros setores da economia norte-americana. Segundo Norman Bailey, então ex-assessor especial do presidente Reagan para política econômica internacional, que testemunhou na ocasião, a crise da dívida teria custado, desde 1982, cerca de US\$ 140 bilhões aos setores produtivos dos países desenvolvidos. "Os organismos que têm sido os principais responsáveis por pagar pela crise da dívida não tinham nada a ver com a crise", afirmou, referindo aos setores industriais e agrícolas dos países credores (U.S. Congress, 1986b, p. 60).

A estratégia democrata de associar a crise da dívida ao déficit comercial se tornaria uma ameaça mais concreta ao governo por meio do projeto de lei H.R. 4800, intitulado Trade and International Policy Economic Reform Act of 1986 e apresentado por deputados do partido no início do ano (Farias, 2007, p. 80). O projeto, considerado pelo governo como altamente protecionista, foi apresentado em 9 de maio e aprovado, a despeito da oposição da Casa Branca, no dia 22 do mesmo mês por 295 votos a favor e 115 contra $^{78}$.

O projeto reconhecia, implicitamente, a relação entre o problema da dívida dos países em desenvolvimento e o déficit comercial dos Estados Unidos. Neste sentido, demonstrava uma intenção de parte dos congressistas de aumentar sua participação nas decisões relativas ao gerenciamento da crise da dívida. Mesmo assim, o projeto limitava-se a fazer recomendações e aceitava o enfoque do Plano Baker, enfatizando o papel do comércio

\footnotetext{
${ }^{78}$ Informações sobre o conteúdo e a tramitação do projeto podem ser encontrado no sistema Thomas da Biblioteca do Congresso, no endereço < http://thomas.loc.gov/cgibin/bdquery/D?d099:1:./temp/ bdOqA8:@@@L\&summ2=m\&|/bss/d099query.html>. Acesso em 22/09/2009.
} 
internacional como indutor do crescimento econômico. No Título I, Subtítulo E, o projeto eliminava as restrições do Sistema Geral de Preferências para os países devedores da América Latina com dificuldades para manter o serviço de suas dívidas, desde que pelo menos $20 \%$ de seu montante fossem devidos a bancos norte-americanos, ao FMI e ao Banco Mundial. Ademais, o Capítulo 3 do Subtítulo B do Título IV obrigava o secretário do Tesouro a instruir o diretor executivo dos EUA no Banco Mundial a propor aos outros diretores o aumento dos empréstimos para ajustes estruturais. Num sinal de que a rationale do Plano Baker continuava a dominar as discussões, o mesmo capítulo exprimia o "sentimento do Congresso" de que o Banco Mundial deveria tomar medidas para aumentar a poupança doméstica e reduzir a fuga de capitais dos países devedores. Nesta linha, o projeto obrigava o secretário do Tesouro a instruir os diretores executivos dos EUA dos bancos multilaterais de desenvolvimento a propor aos outros diretores o aumento de empréstimos para reformar os sistemas financeiros dos países devedores, de forma a ampliar os mercados de capitais destes países.

Apesar de o H.R. 4800 aceitar as premissas do Plano Baker, o governo tentou eliminar qualquer associação entre déficit comercial e crise da dívida por meio de emenda proposta pelo deputado Chalmers Wylie (republicano de Ohio). O governo, porém, não teve sucesso, e a proposta de emenda foi derrotada por 221 votos a 165, em votação que refletiu a divisão partidária sobre a questão ${ }^{79}$.

Incapaz de derrotar o H.R. 4800 na Câmara, onde os democratas tinham maioria folgada (253 assentos contra 182 dos republicanos), o governo conseguiria derrotar a proposta no Senado, no qual sua tramitação parou na Comissão de Finanças em setembro ${ }^{80}$.

O texto da H.R. 4800 também oferece uma ilustração de um mecanismo pelo qual a delegação da crise da dívida para organizações internacionais contribuiu para reduzir a ingerência do Congresso. Embora o projeto tenha sido o primeiro a pressupor claramente que o problema da dívida externa dos países em desenvolvimento tinha consequiências importantes para a economia doméstica dos EUA, ele não conseguiu se livrar da fórmula tradicional de "instruir" o voto do diretor norte-americano em uma organização internacional. Desta forma, a influência do Congresso sobre o tema seria necessariamente indireta, pois o processo de tomada de decisão teria de passar pelo diretor norte-americano na organização. No caso da H.R. 4800, a organização internacional em questão era o Banco Mundial - o que

\footnotetext{
${ }^{79}$ Dos 221 votos a favor, 217 foram de deputados democratas; dos 188 votos contrários, 165 foram de deputados republicanos (Farias, 2007, p. 81).
} 
demonstra também o sucesso do Plano Baker como meio de manter o debate sobre a crise da dívida em termos favoráveis ao Departamento do Tesouro. Como vimos, o gerenciamento da crise permanecia a cargo do FMI e, ao Banco Mundial, a despeito da retórica grandiloqüente de James Baker, coube apenas a função de fornecer fundos adicionais sem que o governo norte-americano tivesse de recorrer a novos pedidos no Congresso.

A pressão democrata no tema de política comercial - assim como o aumento do déficit comercial - continuaria por todo o ano de 1986. A despeito de diversas medidas protecionistas tomadas pelo próprio governo como forma de tentar capturar o tema, o Partido Democrata obteria importante vitória nas eleições de novembro. Além de ampliar em dez cadeiras sua maioria na Câmara, os democratas recuperaram a maioria do Senado e obtiveram maioria expressiva de 55 a 45 assentos.

A vitória eleitoral em novembro levaria as lideranças democratas a manter a pressão no tema de política comercial. Encorajados pela recuperação da maioria no Senado, os democratas intensificariam a associação entre a crise da dívida dos países em desenvolvimento e a explosão do déficit comercial norte-americano. Essa associação abriria espaço para a circulação de diversas propostas de alternativas à gestão da crise da dívida. A pressão crescente pelo abandono da Estratégia dos Cinco Pontos desembocaria no Plano Brady, de 1989. No entanto, nos 28 meses que se passaram entre as eleições legislativas de 1986 e o anúncio do plano de Nicholas Brady, em março de 1989, o FMI teria um papel fundamental em manter a gestão da crise da dívida fora do alcance do Congresso, a despeito da pressão crescente para mudanças de rumo. É o que veremos no capítulo a seguir.

\footnotetext{
${ }^{80}$ Depois de aprovado na Câmara, o H.R. 4800 foi recebido no Senado em 2 de junho de 1986. Ele foi discutido pela última vez na Comissão de Finanças em 23 de setembro de 1986.
} 


\section{O Plano Brady}

Em março de 1989, o novo secretário do Tesouro, Nicholas Brady, anunciou um novo plano do governo norte-americano para a crise da dívida do Terceiro Mundo. O Plano Brady, como ficaria conhecido, incluía pela primeira vez a possibilidade de alívio de dívida para os países em desenvolvimento, e instava as instituições financeiras multilaterais a direcionarem parte de seus recursos para financiar operações dessa natureza. Por isso, o Plano foi visto como uma resposta do governo norte-americano à crescente pressão dos países devedores, incapazes de continuar submetidos a políticas que, com o objetivo de gerar superávits comerciais que lhes permitissem manter em dia os serviços de suas dívidas, os condenavam à estagnação econômica e à deterioração de seus níveis de vida.

Este capítulo argumenta que o principal determinante que levou ao Plano Brady foi a pressão do nível doméstico norte-americano. Após a importante vitória eleitoral em novembro de 1986, os congressistas democratas decidiram aumentar a pressão contra o governo no tema da política comercial. Neste contexto, a estratégia adotada até então pelo governo para crise da dívida dos países em desenvolvimento passou a ser vista como causa dos sucessivos e crescentes déficits comerciais norte-americanos.

Este capítulo também mostrará que a delegação da gestão da crise para o FMI foi fundamental para impedir que o Congresso lograsse alterar a estratégia do Tesouro. Entre novembro de 1986 e março de 1989, a pressão do Congresso nesta matéria seria constante, e incluiria a apresentação de propostas de soluções alternativas para a crise da dívida bastante diferentes da abordagem do governo. Protegido de pressões diretas do Congresso, o FMI foi fundamental para manter a gestão da crise da dívida fora do alcance do Congresso durante todo o governo Reagan. E mesmo embora o Plano Brady tenha representado uma mudança substantiva com relação à Estratégia dos Cinco Pontos, esta mudança se deu sob controle do novo governo e manteve o papel do FMI como gestor da crise.

\subsection{A PRESSÃO EXTERNA: A MORATÓRIA BRASILEIRA}

No nível internacional, o maior desafio à Estratégia dos Cinco Pontos foi protagonizada pelo Brasil. Desde março de 1985, o País recusava-se a negociar um novo acordo com o Fundo. Esta posição foi reforçada com a nomeação de Dilson Funaro como 
ministro da Fazenda em agosto de 1985 (Batista Jr, 1988, p. 28). O acordo de 1983 expirou em fevereiro de 1986 e não foi renovado. Ao contrário, o governo brasileiro manteve a posição de evitar novo compromisso, em grande medida porque sabia que receituário liberal do FMI era incompatível com a política econômica heterodoxa adotada por Brasília desde o início do Plano Cruzado, em fevereiro de 1986 (Boughton, 2001, pp. 453-455).

No segundo semestre de 1986, a situação externa do Brasil começou a se deteriorar, em grande medida em função do aumento da demanda que se seguiu ao Plano Cruzado. Os saldos mensais, que costumavam se manter acima de US\$ 1 bilhão desde 1984, caíram para US\$ 544 bilhões em setembro e transformaram-se em um déficit mensal de US\$ 108 milhões no último trimestre. As reservas também caíram rapidamente, de US\$ 6,8 bilhões em setembro para US\$ 4,6 bilhões em dezembro de 1986 (Batista Jr., 1988, pp. 21-23).

Confrontada com a deterioração da situação externa, a partir de outubro de 1986 a equipe do Ministério da Fazenda passou a defender a suspensão dos pagamentos da dívida externa, como forma de preservar as reservas internacionais e aumentar o poder de barganha do País nas negociações que se seguiriam, evitando a repetição da crise de 1982 (Batista Jr., 1988, p. 25, 29). Esta decisão representava, evidentemente, um rompimento com o caminho adotado até então, no qual negociava-se com o FMI e, em troca da adoção de um doloroso programa de redução da demanda doméstica, obtinham-se empréstimos que permitiriam a continuidade dos pagamentos da dívida até que fosse restabelecido o "equilíbrio" das contas externas. O caminho tradicional, de negociação com o Fundo, era defendido por diversas autoridades do Banco Central (inclusive seu presidente, Fernão Bracher), e pelo embaixador do Brasil em Washington, Marcílio Marques Moreira. Este grupo caracterizava a proposta do Ministério da Fazenda como a "via peruana" que, uma vez adotada, tornaria o Brasil alvo das mais diversas represálias (ibidem, p. 27).

A posição do Ministério da Fazenda prevaleceu e, em 20 de fevereiro de 1987, o presidente Sarney surpreendeu o País, o mundo e o Fundo ao declarar uma moratória dos pagamentos de juros sobre as dívidas bancárias de médio e longo prazo, que somavam cerca de US\$ 69 bilhões. Às taxas de juros vigentes naquele momento, isto representava uma redução de cerca de US\$ 500 milhões por mês em remessas para o exterior. Note-se que, naquele momento, as reservas do País já tinham caído para cerca de US\$ 3 bilhões. Todos os juros seriam temporariamente depositados em uma conta no Banco Central do Brasil, e seu pagamento aos bancos credores se daria em condições a serem acertadas por meio de 
negociações diretas entre o governo brasileiro e os credores (Boughton, 2001, p. 458, Batista Jr., 1988, pp. 31-32).

Como mostra Paulo Nogueira Batista Jr., a moratória era fundamentalmente um instrumento de negociação. O objetivo era alterar o padrão de relacionamento entre vigente até então entre o País e os credores. Entre outras medidas, o Ministério da Fazenda propunha o fim do pagamento, pelo governo brasileiro, das despesas do comitê de bancos credores (oficialmente um comitê "consultivo"), a mudança do local e do formato das negociações (que ocorriam na sede do Citibank em Nova York e eram concebidas "para deixar o Brasil em posição de ostensiva inferioridade"), e o aumento do peso dos bancos europeus no comitê, pois eles operavam com regulamentos bancários mais favoráveis ao Brasil (Batista Jr, 1988, pp. 57-58). Nota-se que as medidas não visavam a questionar a própria dívida externa, mas sim as condições sob as quais ela tinha sido negociada até então.

A moratória brasileira foi uma medida sem precedentes, mais grave até mesmo do que a decisão do Peru, em 1985, de limitar seus pagamentos de juros a $10 \%$ do total de suas exportações. Mesmo assim, a estratégia era evitar o confronto direto e a retórica exagerada. Em documento transmitido ao presidente Sarney, o Ministério da Fazenda propôs que a medida fosse anunciada "em tom sereno", sem utilizar "retórica nacionalista, terceiromundista ou confrontacionista", e "ancorada em sólida fundamentação técnica" que "demonstre a inevitabilidade de tanto o Brasil quanto seus credores atacarem de frente o problema da dívida, cuja única solução está na manutenção do modelo de crescimento" (Batista Jr., 1988, pp. 34-35). O telegrama enviado pelo Brasil aos bancos credores anunciando a moratória em 20 de fevereiro daria ênfase à necessidade de se assegurar o crescimento econômico como forma de superar a crise. A similaridade com a retórica do Plano Baker também procurava reduzir o tom confrontacionista da medida, enquadrando-a não como um ato de desafio ao sistema financeiro, mas como um instrumento legítimo de negociação com os bancos internacionais.

“A confiança no Brasil foi perdida”, reagiu Paul Volcker ao anúncio da moratória, enquanto John Reed, presidente do conselho do Citibank, avisou que o País não deveria esperar facilidades dos bancos credores (Veja, 1987a, pp. 24, 27). O Financial Times publicou editorial caracterizando a medida brasileira como "populismo econômico" (ibidem, p. 27) e o Washington Post acusou a política econômica do governo Sarney, que teria tentado "comprar popularidade com aumentos de salário altamente inflacionários”, de ser a principal causa da 
crise brasileira (Washington Post, 1987). Fora do campo da retórica, contudo, pouco aconteceu. Houve certa redução das linhas de crédito de curto prazo e o aumento dos juros e a redução dos prazos destes empréstimos. Por outro lado, as reservas se estabilizaram em cerca de US\$ 3,3 bilhões de dólares e, a partir de maio, voltariam a subir (Batista Jr., 1988, p. 84). Ao contrário do que vaticinaram os opositores da moratória, o Brasil não foi vítima de confisco de bens no exterior, não perdeu acesso ao mercado externo nem se viu obrigado a se fechar em uma economia autárquica.

De fato, a reação dos bancos foi quase tão surpreendente quanto a própria moratória brasileira. Em 19 de maio, o Citibank anunciou que estava elevando em US\$ 3 bilhões suas provisões contra perdas com empréstimos a países em desenvolvimento. Esta medida causaria um prejuízo da ordem de US\$2,5 bilhões no segundo trimestre de 1985 — o segundo maior prejuízo da história dos EUA (Berg, 1987). Mesmo assim, a medida aumentou a confiança do mercado de capitais na instituição, já que indicava disposição de reduzir rapidamente sua exposição aos devedores do Terceiro Mundo (Madrid, 1992, p. 125). A reação positiva do mercado levaria os outros grandes bancos a seguir o Citi. O Chase aumentou suas reservas em US\$ 1,58 bilhão, o Manufacturers Hanover em US\$ 1,59 bilhão, o Chemical em US\$1,35 bilhão e o Bank of America em US\$ 971 milhões. A elevação das reservas obrigou os grandes bancos a vender ativos e cortar custos para recuperarem seu capital: o Citibank vendeu parte de sua sede, o Chemical demitiu dois mil funcionários e vendeu subsidiárias, o Chase vendeu uma subsidiária e edifícios na França e no Japão (Carneiro dos Santos, 1991, pp. 142-143).

Os aumentos de reservas foram vistos como uma forma de os bancos endurecerem suas posições com relação aos países em desenvolvimento, pois, ao assumirem um grande prejuízo de uma vez, reduziam o poder de barganha dos países devedores ${ }^{81}$. Por outro lado, o aumento das reservas indicava que o sistema bancário norte-americano já tinha superado a fase de maior vulnerabilidade, podendo inclusive absorver perdas relativamente grandes sobre seus empréstimos a países em desenvolvimento. Desta forma, a decisão dos bancos poderia ser vista como uma abertura para que as resistências a mudanças na abordagem adotada para a dívida desde 1982 fossem superadas ${ }^{82}$.

A maior reação contrária à moratória brasileira viria, paradoxalmente, do próprio nível doméstico brasileiro. Uma semana antes do anúncio da moratória, Fernão Bracher pediu demissão da presidência do Banco Central. Publicamente, Bracher afirmou que a demissão

\footnotetext{
${ }^{81}$ Para um síntese desta posição, cf. Carneiro dos Santos (1991).
} 
devia-se às discordâncias com Funaro, mas seu discurso de despedida traiu outros motivos: segundo ele, era preciso abandonar "os sonhos, as bravatas, a escapatória do inimigo externo" (Parola, 1991, p. 114) ${ }^{83}$. Ao contrário do que ocorrera com o Plano Cruzado, que dera início a uma grande mobilização popular de apoio ao governo, o anúncio da moratória foi recebido com frieza e desconfiança. Alguns empresários criticaram duramente a medida: "somos nós, a classe produtora e a população, que teremos de arcar com as conseqüências", afirmou, por exemplo, o presidente da associação dos produtores de papel e celulose (Veja, 1987a, p. 24). O senador do PDS Roberto Campos atribuiu a moratória a "incompetência e imprudência" do governo, enquanto o deputado do PT Luiz Inácio Lula da Silva afirmou que a moratória significava apenas que o Brasil estava quebrado (Riding, 1987). Até mesmo o PMDB, a despeito das declarações eloqüentes de algumas lideranças, teve no geral uma reação bastante morna (Batista Jr., 1988, p. 97). Em grande medida, isto se deveu ao fracasso do Plano Cruzado, que isolara Funaro e erodira o capital político do próprio presidente Sarney.

A reação negativa no Brasil levou Sarney a recuar em seu propósito de usar a moratória como instrumento para alterar a estrutura das negociações com os bancos credores. Emissários do Planalto foram enviados aos Estados Unidos para tratar diretamente com autoridades norte-americanas, contornando Funaro. A fraqueza política de Funaro praticamente eliminou a credibilidade do principal negociador brasileiro. Como disse David Mulford, então secretário-assistente do Tesouro para assuntos internacionais, a um grupo de jornalistas, “ou mudará a política e o Brasil adotará uma política econômica ortodoxa, ou mudará o ministro, seguindo-se a adoção de um plano econômico ortodoxo" (Veja, 1987b). Face a um ministro com o capital político totalmente erodido, os grandes bancos preferiram esperar sua substituição a adotar uma postura de confronto direto. Por fim, "fritado" por Sarney e sem apoio do PMDB, Funaro acabaria deixando o governo em 29 de abril, substituído por Luiz Carlos Bresser Pereira ${ }^{84}$.

Bresser Pereira assumiu o ministério da Fazenda com uma postura conciliadora com relação aos bancos internacionais e com planos de reduzir o déficit público por meio de cortes de gastos e aumentos de impostos, liberalização do comércio exterior e privatização de empresas estatais. No entanto, o novo ministro rapidamente percebeu que a estabilização

\footnotetext{
${ }^{82}$ Batista Jr. (1991) defende esta posição.

${ }^{83}$ Roberto Gianetti da Fonseca confirma que foi a moratória que fez Bracher "abandonar a presidência do Banco Central" (2002, p. 221).

${ }^{84}$ Sobre a "fritura" de Funaro, cf. Veja, "Dilson Funaro frito em fogo brando", 15/04/1987.
} 
econômica seria impossível se o Brasil voltasse a pagar integralmente os juros da dívida externa. Fazia-se necessária, portanto, alguma forma de redução dos serviços da dívida.

Em julho, Bresser Pereira viajou para Washington para iniciar conversações sobre uma proposta de securitização da dívida do Brasil, como forma de reduzir os juros pagos pelo País. Na capital norte-americana, foi informado pelo embaixador Marcílio Marques Moreira que duas resoluções aprovadas pelo Congresso defendiam a concessão de "alívio da dívida" aos países em desenvolvimento, o que se alinhava com sua própria proposta. Bresser conversou com o senador Bill Bradley, um dos maiores proponentes da adoção de uma estratégia alternativa para a crise da dívida, e comentou ter percebido um "clima favorável", nos países desenvolvidos, a novas abordagens para a crise da dívida. Também se reuniu com Michael Camdessus - que poucos meses antes substituíra Jacques de Larosière na direção do FMI e com Barber Conable para apresentar a idéia de securitização da dívida. Ambos reagiram com cautela. "Washington não está madura ainda [para isso]", disse-lhe Camdessus. Conable foi na mesma linha, afirmando ter gostado da idéia, mas que qualquer decisão seria tomada pelos acionistas do Banco (Bresser, 1999, p. 111-112).

De volta ao Brasil, a equipe da Fazenda desenvolveu uma proposta que incluía a securitização de $20 \%$ da dívida externa brasileira com desconto de $50 \%$ sobre o valor de face, e desvinculação do FMI das negociações com os bancos comerciais. A proposta da Fazenda enfrentou grande oposição dentro do próprio governo Sarney, particularmente do embaixador Marcílio Marques Moreira, do Assessor Internacional do Presidente, Rubens Ricúpero, e do genro de Sarney, Jorge Murad. Apesar da resistência, o presidente acabou aprovando a proposta de Bresser e autorizou-o a apresentá-la ao governo norte-americano e às organizações internacionais (Bresser, 1999, pp. 113-114).

No final de agosto, Bresser viajou para Washington, a pedido de James Baker, para apresentar sua proposta de securitização. Bresser encontrou-o no dia 8 de setembro, logo depois de participar, a convite de Bill Bradley, de uma conferência sobre a crise da dívida organizada pelo Congresso. Antes da reunião, parte da proposta brasileira vazou para a imprensa. Para piorar, foi vazada uma versão incorreta da proposta, o que levou setores da imprensa norte-americana a caracterizá-la como "revolucionária" e "perigosamente radical", a superestimar a proporção de alívio da dívida e a ver na iniciativa um risco ao sistema 
financeiro internacional ${ }^{85}$. Um executivo do Citibank chamou publicamente a proposta de "maluca" (Truell, 1987a). Em função disto, ao encontrar-se com Baker, Bresser encontrou um clima hostil (Bresser, 1999, pp. 114-115). Segundo Bresser,

O Secretário de Estado estava claramente sob pressão dos bancos e da imprensa. A impressão que um ministro das finanças de um país em desenvolvimento estava desafiando os bancos e o establishment de Washington, tomando iniciativas que apenas o Tesouro dos EUA poderia tomar (ibidem, p. 115).

Baker e Bresser inicialmente tiveram uma reunião privada, na qual o ministro brasileiro apresentou sua proposta. Baker foi taxativo: "Isso não dá. Não concordo. É um nonstarter" (Bresser, 1992). Bresser consultou então sobre a possibilidade de se realizar uma securitização voluntária de parte de dívida, e de desvincular o acordo com os bancos de um acordo com o FMI. Baker concordou com ambas as idéias. A seguir, foi realizada uma reunião aberta, com a presença das equipes dos dois ministros. Nesta reunião, David Mulford, secretário assistente para Assuntos Internacionais, e Charles Dallara, diretor executivo dos EUA no FMI, opuseram-se frontalmente a qualquer forma de securitização, mesmo que voluntária, assim como à idéia de desvincular o FMI das negociações, afirmando que a conexão entre as organizações internacionais e os bancos comerciais era uma "característica essencial" das negociações (Bresser, 1999, pp. 115-116).

Depois do encontro, Baker mudou de posição e soltou uma agressiva nota à imprensa, na qual afirmou apenas que Bresser apresentara-lhe uma proposta que era um non starter. A nota não mencionava nenhuma concordância entre os dois. "Foi uma nota de um poder hegemônico", afirmaria Bresser muitos anos depois (1999, p. 117).

O non starter de Baker teve o efeito político imediato de enfraquecer Bresser no Brasil. "Um fiasco de dimensões internacionais", caracterizou a revista Veja. "Bresser submeteu o Brasil a um vexame", atacou o ex-presidente do Banco Central Affonso Celso Pastore, para quem o ministro da Fazenda "se desqualificou como negociador internacional" (Veja, 1987c, p. 18).

Bresser também tentaria coordenar as posições de Brasil, Argentina e México. Em 25 de setembro, ele almoçou com o ministro da Economia da Argentina, Juan Sorrouille, e com o

\footnotetext{
${ }^{85}$ A proposta brasileira apareceu pela primeira vez na imprensa norte-americana pelo Wall Street Journal (Cohen, 1987). No dia seguinte, outra reportagem do Wall Street Journal afirmou que os bancos credores consideraram a proposta "perigosamente radical" (Truell, 1987a). No dia 8 de setembro, novo artigo do Wall Street Journal afirmou que a proposta "parece assegurar uma confrontação direta entre o Brasil e seus credores externos por vários meses" e que, caso o Brasil tivesse sucesso, outros grandes devedores seguiriam seu exemplo, o que poderia “quebrar vários grandes bancos internacionais” (Truell, 1987b).
} 
ministro da Fazenda do México, Gustavo Petricciolli. Foi a única reunião do grupo. Segundo Bresser, "depois, os mexicanos se desinteressaram pela idéia" (1992). Confirmava-se, mais uma vez, a grande dificuldade de os países devedores atuarem conjuntamente com relação à dívida externa.

No final de setembro, a idéia de alívio da dívida já era corrente no Congresso norteamericano. Neste contexto, Baker passaria a mostrar algum apoio à proposta de securitização apresentada por Bresser, desde que fosse estritamente voluntária e que o Brasil concordasse em encerrar a moratória imediamente e fechasse um acordo temporário com os bancos. Isto foi feito em novembro, quando o País finalmente assinou um acordo no qual se comprometeu a pagar US\$ 500 milhões aos bancos e a negociar um programa de estabilização com o FMI.

Ao mesmo tempo, a equipe da Fazenda continuou trabalhando numa proposta de securitização, com vistas a apresentar uma oferta de troca de dívida "velha" por títulos "novos" no começo de janeiro. No entanto, em meados de dezembro Bresser Pereira foi demitido pelo presidente Sarney, que o substituiu por Mailson da Nóbrega (Bresser, 1999, pp. 119-120, 123, 126-127, Fonseca, 2006, pp. 236-240). O novo ministro, uma vez confirmado no cargo, decidiu encerrar em definitivo a negociação de securitização da dívida e suspender a moratória incondicialmente, pagando todos os juros atrasados (Fonseca, 2002, p. 240).

O episódio da moratória brasileira mostra, em primeiro lugar, que o governo dos EUA trabalhou ativamente para manter o FMI no centro da gestão da crise da dívida, pois o Fundo era um componente essencial da Estratégia dos Cinco Pontos. Este episódio também indica que os governos dos países devedores enfrentavam enormes resistências de ordem doméstica a desafiar a abordagem do Tesouro para a crise. Para além da evidente oposição que o Brasil enfrentou dos bancos comerciais e do Tesouro, a principal resistência à moratória brasileira veio de setores políticos domésticos, incluindo bancos, empresas ligadas ao mercado externo e mesmo integrantes do próprio governo que discordavam da equipe do ministério da Fazenda.

Ademais, por melhor que fosse a alternativa proposta pelo Brasil para solucionar a crise da dívida, a reação de Baker à proposta de securitização da dívida formulada por Bresser indica que o governo norte-americano podia, com alguma facilidade, frustrar eventuais tentativas de um país em desenvolvimento de romper com a Estratégia dos Cinco Pontos. Em grande medida, o poder norte-americano se devia à incapacidade dos governos devedores de 
coordenarem posições: durante toda a duração da moratória, os principais países da região evitaram manifestar apoio à iniciativa brasileira.

\subsection{A PRESSÃO DOMÉSTICA: O ATIVISMO DO CONGRESSO}

O maior ataque à estratégia do Tesouro para a crise da dívida viria do próprio nível doméstico norte-americano. A vitória democrata nas eleições legislativas de novembro de 1986 inauguraria uma fase de grande ativismo do Congresso, que procuraria forçar o Executivo a adotar diversos planos alternativos para lidar com a crise.

Antes mesmo da posse da nova legislatura, em dezembro de 1986, um grupo de congressistas organizou uma conferência internacional para discutir a crise da dívida. Realizado em Nova York nos dias 4 e 5 de dezembro, o evento, intitulado Cúpula do Congresso dos EUA sobre Dívida e Comércio, reuniu congressistas norte-americanos e ministros da Fazenda de diversos países, inclusive o secretário do Tesouro, James Baker, que foi o keynote speaker. $\mathrm{O}$ evento demonstrou que os congressistas norte-americanos passaram definitivamente a ver a abordagem do Tesouro para a crise da dívida como uma das causas dos déficits comerciais norte-americanos. Ademais, personalidades européias e japonesas também defenderam a necessidade de um "alívio temporário" para os países devedores, de forma que eles pudessem recuperar o crescimento econômico. Entre elas, destacou-se o gerente-geral do Swiss Bank, Franz Leutols, que afirmou ter "chegado a hora" de reconhecer que muitos devedores não podiam mais continuar pagando os juros sobre suas dívidas (Rowen, 1986). O Plano Baker foi duramente atacado. O senador Bill Bradley, que desde 1983 defendia uma alteração na estratégia norte-americana para a crise, afirmou que o plano "está prolongando as políticas que criaram a crise da dívida", e aproveitou para defender sua proposta de redução da dívida (The Times, 1986). "Há hoje a necessidade de uma nova abordagem”, afirmou Henry Kaufman, um diretor do Salomon Brothers. O Plano Baker foi defendido apenas pelos representantes dos bancos norte-americanos e pelo próprio James Baker.

Após a posse da nova legislatura, o tema da crise da dívida imediatamente ganhou relevo. Os democratas substituíram os republicanos nas presidências das comissões e subcomissões e adotaram, desde as primeiras semanas, posição bastante assertiva sobre o tema. A presidência da Subcomissão de Dívida Internacional do Senado foi assumida por Bill Bradley, o mais vocal proponente de uma abordagem alternativa para a crise. 
No primeiro dia da legislatura (6 de janeiro ${ }^{86}$ ), o projeto H.R. 4800 da legislatura anterior foi reapresentado como H.R. 3 e intitulado Trade and International Economic Policy Reform Act of 1987. O H.R. 3 abandonava o apoio implícito da H.R. 4800 ao Plano Baker e associava diretamente o aumento do déficit comercial norte-americano com a estratégia adotada até então para a crise da dívida. Os debates em torno deste projeto foram intensos. Como mostra a Tabela 7.1, em menos de cinco meses foram realizadas sete audiências nas quais a crise da dívida foi o tema central.

Tabela 7.1

Audiências realizadas em 1987 no Senado e na Câmara sobre a crise da dívida

\begin{tabular}{|c|c|c|c|}
\hline Data & Casa & Comissão & Tema \\
\hline $\begin{array}{l}3 \text { e } 4 \text { de } \\
\text { março }\end{array}$ & Câmara & $\begin{array}{l}\text { Subcomissão de Instituições Internacionais de } \\
\text { Desenvolvimento e Finanças da Comissão de } \\
\text { Bancos, Finanças e Assuntos Urbanos }\end{array}$ & $\begin{array}{l}\text { Dívida do Terceiro } \\
\text { Mundo }\end{array}$ \\
\hline $\begin{array}{l}3,4 \text { e } 10 \text { de } \\
\text { março }\end{array}$ & Câmara & $\begin{array}{l}\text { Subcomissão de Finanças Internacionais, Comércio } \\
\text { e Política Monetária da Comissão de Bancos, } \\
\text { Finanças e Assuntos Urbanos }\end{array}$ & $\begin{array}{l}\text { Cláusulas bancárias da } \\
\text { Lei de Comércio }\end{array}$ \\
\hline 9 de março & Senado & $\begin{array}{l}\text { Subcomissão de Dívida Internacional da Comissão } \\
\text { de Finanças }\end{array}$ & $\begin{array}{l}\text { Impacto da crise da } \\
\text { dívida da América } \\
\text { Latina sobre os EUA }\end{array}$ \\
\hline $\begin{array}{l}26 \text { de março } \\
\text { e } 1,2 \text { e } 7 \text { de } \\
\text { abril }\end{array}$ & Senado & $\begin{array}{l}\text { Subcomissão de Finanças Internacionais e Política } \\
\text { Monetária da Comissão de Bancos, Habitação e } \\
\text { Assuntos Urbanos }\end{array}$ & $\begin{array}{l}\text { Taxas de câmbio e } \\
\text { dívida do Terceiro } \\
\text { Mundo }\end{array}$ \\
\hline $\begin{array}{l}2,8 \text { e } 23 \text { de } \\
\text { abril e } 20 \text { de } \\
\text { maio }\end{array}$ & Câmara & $\begin{array}{l}\text { Subcomissão de Instituições Internacionais de } \\
\text { Desenvolvimento e Finanças da Comissão de } \\
\text { Bancos, Finanças e Assuntos Urbanos }\end{array}$ & $\begin{array}{l}\text { Bancos multilaterais } \\
\text { de desenvolvimento }\end{array}$ \\
\hline 6 de abril & Senado & $\begin{array}{l}\text { Subcomissão de Dívida Internacional da Comissão } \\
\text { de Finanças }\end{array}$ & $\begin{array}{l}\text { Problema da dívida do } \\
\text { Terceiro Mundo }\end{array}$ \\
\hline 23 de abril & Câmara & $\begin{array}{l}\text { Subcomissão de Finanças Internacionais, Comércio } \\
\text { e Política Monetária da Comissão de Bancos, } \\
\text { Finanças e Assuntos Urbanos }\end{array}$ & $\begin{array}{l}\text { Crise da dívida } \\
\text { brasileira }\end{array}$ \\
\hline
\end{tabular}

Além da simples quantidade de audiências realizadas, a composição dos painéis de depoentes demonstra a mudança de enfoque do Congresso. Autoridades do Tesouro, representantes de bancos e acadêmicos continuaram a participar; mas passaram a ser acompanhados de representantes de sindicatos, de associações da agricultura e da indústria, e

\footnotetext{
${ }^{86}$ As datas de início e término das legislaturas podem ser encontradas em <www.gpoaccess.gov/help/congress_table.html>. Acesso em 18/01/10. Os dados relativos à tramitação do
} 
de congressistas de distritos que sofreram prejuízos econômicos causados pelo déficit comercial. Como sempre, representantes das instituições multilaterais não participaram, pois não podem ser convocados pelo Congresso. Desta forma, escaparam do constrangimento de terem de defender a estratégia para a crise perante os deputados e senadores.

A análise dos depoimentos mostra que o movimento por mudanças na estratégia vigente para a crise da dívida tinha ganhado muita força, inclusive entre os congressistas.

O principal argumento dos que demandavam mudanças era que a abordagem adotada até então causava redução das exportações para os países devedores, aumento das importações oriundas destes países e, conseqüentemente, desaceleração econômica e desemprego nos Estados Unidos.

O deputado William Fauntroy (democrata do Distrito de Columbia), presidente da Subcomissão de Instituições de Desenvolvimento e Finanças Internacionais, abriu a audiência de 3 de março sobre a H.R. 3 afirmando que

A crise da dívida do Terceiro Mundo com os bancos comerciais obstruiu o crescimento da América Latina e restringiu as exportações norte-americanas para aquela região. Os efeitos da crise da dívida latino-americana sobre o comércio dos EUA foram particularmente perturbadores para os fazendeiros e para as indústrias norte-americanas ${ }^{\mathrm{xxxvii}}$. (U.S. House, 1987b, p. 1).

Bill Bradley, ao abrir a audiência de 9 de março, fez uma interessante ilustração do problema:

Digamos que você dirija uma loja de ferramentas em Fairmont, Minnesota. A maior parte de seus clientes é composta por fazendeiros. O que vai acontecer com seu negócio à medida que a crise do crédito agrícola se aprofundar? Se seus clientes usarem parcela cada vez maior de seus rendimentos apenas para pagar os juros de seus empréstimos, eles vão reduzir as compras em sua loja. Você vai ter sorte se conseguir manter sua loja aberta. [...]

Os EUA são similares à loja de ferramentas em Fairmont. E a América Latina é o consumidor cheio de problemas. As nações da América Latina são nossos parceiros naturais de crescimento; eles são nossos vizinhos. Se temos esperança de que nossos filhos venham a gozar do mesmo tipo de crescimento econômico que nós tivemos depois da II Guerra Mundial, temos de ajudar esses vizinhos a prosperar. Clientes prósperos fazem uma loja próspera ${ }^{\text {xxxviii }}$. (U.S. Senate, 1987a, p. 2).

Richard Feinberg, vice-presidente do Overseas Development Council, resumiu o impacto da crise sobre os produtores norte-americanos em seu depoimento perante a Subcomissão de Finanãs Internacionais, Comércio e Política Monetária da Câmara da seguinte forma:

Nos últimos cinco anos, a América Latina foi obrigada a transferir US\$ 132 bilhões para credores estrangeiros. Esta tranferência de recursos não apenas inibe obviamente o 
crescimento dos países em desenvolvimento mas também encolhe os mercados para as exportações dos EUA. Ademais, para conseguir as divisas internacionais necessárias aos pagamentos de juros, as nações endividadas devem obter grandes superávits comerciais $^{\text {xxxix }}$. (U.S. House, 1987a, p. 107).

Em outro depoimento, dessa vez perante a Subcomissão de Dívida Internacional, Feinberg estimou que a queda das exportações dos EUA para os países do Terceiro Mundo entre 1980 e 1985 causara uma perda de 600 mil empregos, dos quais 360 mil relacionados diretamente às exportações para a América Latina. Na mesma linha, Feinberg estimou que 930 mil empregos teriam sido criados desde 1980 se o crescimento do Terceiro Mundo tivesse prosseguido no ritmo registrado na década de 1970. Feinberg admitiu que alguns países em desenvolvimento mantinham "níveis altos e injustos de protecionismo", mas sublinhou que "a principal barreira enfrentada pelas exportações dos EUA em muitos mercados não são as leis tarifárias, mas a escassez de dólares" (U.S. Senate, 1987a, p. 41):

Cada dólar enviado para um money center bank é um dólar a menos para ser gasto em trigo produzido no Iowa ou caminhões feitos em Michigan. Eu argumentaria [...] que a atual alocação do peso da dívida não responde ao nosso interesse nacional de longo prazo. Ele coloca os interesses dos bancos acima dos interesses de nossos industriais e agricultores exportadores $^{\mathrm{xl}}$ (ibidem).

John Plunket, representante da Associação de Câmaras Norte-Americanas de Comércio na América Latina, quantificou as perdas dos exportadores norte-americanos derivadas da crise da dívida. Segundo ele, as exportações dos EUA para a América Latina somaram US\$ 42 bilhões em 1981, mas em 1985 e 1986 tinham atingido apenas US\$ 30 bilhões - uma redução de US\$ 12 bilhões. Ressaltou que, segundo estudos do Departamento de Comércio, a queda nas exportações fora responsável por cerca de $80 \%$ da redução no número de empregos relacionados ao setor manufatureiro norte-americano entre 1980 e 1984 (U.S. Senate, 1987a, p. 151).

Representando o setor industrial, Steve Beckman, economista do poderoso sindicato United Auto Workers (UAW), apresentou, na mesma audiência, estimativas que indicavam que, somente no setor de implementos agrícolas e equipamentos para construção civil, 50\% dos empregos foram perdidos entre 1980 e 1986 - em grande medida por causa da queda nas exportações para os países em desenvolvimento. Segundo Beckman, as exportações realizadas por este setor caíram de US\$13,8 bilhões para US\$ 7,1 bilhões entre 1981 e 1986 - um declínio de US\$ 6,7 bilhões, dos quais a redução de vendas para a América Latina teria respondido por US\$ 2 bilhões (U.S. Senate, 1987a, pp. 65). 
Na indústria automobilística, a balança comercial apresentava superávit a favor dos EUA de US\$ 2,8 bilhões em 1981, que foi revertida para um déficit de US\$ 1,5 bilhão em 1986. As exportações de automóveis oriundos da América Latina cresceram mais de 400\%, subindo de US\$ 800 milhões em 1981 para US\$ 4,2 bilhões em 1986. Por causa dos efeitos sobre os trabalhadores norte-americanos, Beckman propunha que o governo norte-americano adotasse uma distribuição "justa" do impacto da crise da dívida, de maneira a fazer com que os bancos compartilhassem seus custos (U.S. Senate, 1987a, pp. 65-66).

O setor agrícola também se fez representar nas discussões. O secretário de Agricultura do estado do Kansas, Sam Brownback, mostrou que o setor passava por uma de suas maiores crises em décadas. A seguir, associou esta crise ao problema da dívida:

As formas existentes de lidar com o problema da dívida da América Latina — da parte do Plano Baker, do Fundo Monetário Internacional e do Banco Mundial - apenas agravam o problema. Ao emprestar aos países endividados ainda mais dinheiro, elas encorajaram o aumento das exportações para gerar capital para pagar o serviço das dívidas para os money center banks dos EUA. O aumento forçado das exportações da América Latina reduz as exportações de nossos agricultores e levam a um círculo vicioso de queda dos preços das commodities em todo o mundo ${ }^{\text {xli }}$. (U.S. Senate, 1987a, p. 78.)

A seguir, Brownback afirmou estranhar que a forma como a crise da dívida dos países da América Latina estava sendo gerida era totalmente diferente da maneira como a crise da dívida dos agricultores era tratada:

Parece de fato muito estranho que haja regras diferentes para os bancos rurais e para os grandes bancos multinacionais. Seria difícil para os bancos rurais do Kansas sobreviver se a resposta deles aos fazendeiros que não pudessem pagar seus empréstimos fosse emprestar-lhes ainda mais dinheiro que não seriam capazes de devolver. [...] Ao contrário, os bancos rurais do Kansas vêem-se obrigados a renegociar aqueles empréstimos com problemas, para encontrar uma forma de o fazendeiro reduzir sua dívida, em vez de aumentá-la. [...]

Parece lógico para mim que os grandes bancos multinacionais deveriam responder às nações devedoras de uma forma similar; no entanto, a resposta deles parece ser colocar dinheiro bom em cima do ruim, aumentando assim a dívida e os lucros dos bancos, mas quase que garantindo a continuidade do ciclo de queda dos preços das commodities e de agitações sociais e políticas. Os meios de sustento do fazendeiro do Kansas e do campesino latino-americano estão ambos sendo reduzidos por políticas que são contraproducentes para o desenvolvimento democrático e econômico da América Latina ${ }^{\text {xlii }}$. (U.S. Senate, 1987a, pp. 78-79).

Argumento similar foi apresentado por James Lee Adams, vice-presidente da

\section{Associação Americana da Soja:}

Além de reduzirem as importações de produtos agrícolas norte-americanos, os devedores da América Latina aumentaram significativamente suas exportações de commodities agrícolas para os mercados dos EUA e do Terceiro Mundo. [...] Em 1979, os Estados Unidos respondiam por $41 \%$ das exportações de soja, enquanto o Brasil e a Argentina combinados tinham uma participação de 32\%. [...] Em 1985, Brasil e Argentina possuíam 
47\% do mercado mundial, enquanto nós tínhamos menos de 25\% xliii . (U.S. Senate, 1987a, pp. 81-82)

A maioria dos depoentes concordava que, enquanto indústrias e agricultores arcavam com os custos do ajuste na América Latina, os grandes bancos beneficiavam-se da estratégia de gerenciamento vigente. Como resumiu Richard Feinberg, "a estratégia atual coloca os interesses dos bancos acima dos interesses dos nossos industriais e agricultores exportadores" (U.S. House, 1987b, p. 46). Na mesma linha, segundo William Fauntroy,

Enquanto as indústrias dos Estados Unidos e os cidadãos da América Latina pagaram um preço tremendo, na prática financiando as atividades das elites e dos bancos internacionais, os próprios bancos até agora saíram relativamente incólumes ${ }^{\text {xliv }}$. (U.S. House, 1987b, p. 2).

Para o economista Rudiger Dornbusch, a estratégia vigente era uma aplicação da supply side economics para a crise da dívida, na qual os países da América Latina se endividariam ainda mais e apenas os bancos se beneficiariam:

Creio que as partes substantivas do plano Baker são equivalentes à supply side economics. Nos Estados Unidos, temos experiência com [essa política] e ainda a vemos em nossos déficits orçamentários. Ela simplesmente não vai funcionar. [...] O crescimento foi negativo. O plano Baker serviu principalmente para a redução da exposição por parte dos bancos comerciais $^{\text {xlv }}$. (U.S. House, 1987b, p. 42, grifo meu.)

Naturalmente, todos os críticos da abordagem vigente para a crise da dívida defendiam a adoção de uma estratégia alternativa. Todas as estratégias propostas envolviam alguma forma de "alívio da dívida", ou seja, visavam a reduzir os juros ou os montantes devidos e alongar os prazos de pagamento, de maneira a liberar recursos para que os países endividados pudessem reduzir seus superávits comerciais.

O cerne do argumento a favor do alívio da dívida foi resumido por Karin Lissakers em seu depoimento de 2 de abril:

A atual estratégia da dívida não resolve o problema. Eu duvido que qualquer estratégia que não inclua alguma forma de alívio da dívida resolva. Por [alívio da dívida] eu quero dizer [...] uma redução dos créditos dos bancos e [...] a transferência destes benefícios, dos descontos, para os países devedores ${ }^{\text {xlvi }}$. (U.S. Senate, 1987b, pp. 249-250.)

Para seus defensores, formas de alívio da dívida eram necessárias porque reduziriam a transferência de recursos dos países em desenvolvimento - em particular os da América Latina - para os países industrializados. Com mais recursos à disposição, os países devedores poderiam reduzir seus superávits em balança comercial - que eram obrigados a obter para manter em dia o serviço de suas dívidas - e, assim, importar mais e exportar menos. O aumento das importações dos países da América Latina seria particularmente benéfico para os EUA, tradicionalmente o maior exportador para a região. Da mesma forma, a 
redução das exportações latino-americanas reduziria a competição enfrentada pelos produtores agrícolas dos EUA.

Um pressuposto dos argumentos a favor de alívio da dívida era que os bancos, depois de cinco anos reduzindo sua exposição aos países em desenvolvimento, estavam em condição de assumir prejuízos. Como afirmou Richard Feinberg,

Uma melhoria na equação dívida/comércio que desestabilizasse o sistema bancário dos EUA não seria favorável ao interesse nacional; mas há alguma margem de manobra. Os bancos comerciais estão hoje numa posição melhor do que quando a crise da dívida estourou em 1982 e poderiam absorver uma proporção maior dos custos de seus erros passados $^{\text {xlvii }}$. (U.S. Senate, 1987a, p. 42.)

Diversos congressistas mostravam-se favoráveis à criação de uma agência que compraria as dívidas dos países da América Latina pelo valor de mercado (ou seja, com o desconto que estava sendo praticado no mercado secundário) e repassaria o desconto aos países devedores. Uma proposta neste sentido fora apresentada já no início de 1983 pelo banqueiro de investimentos Felix Rohatyn. Na proposta de Rohatyn, a nova agência “compraria” dos bancos as dívidas dos países em desenvolvimento, dando em troca títulos de longo prazo garantidos pela própria agência e com juros menores. As dívidas de curto prazo seriam, assim, substituídas por títulos com prazo de 25 ou 30 anos, e juros de $6 \%$ ao ano. Note-se que a substituição só seria possível porque a agência garantiria os títulos — o que significava, em última análise, que as dívidas dos países em desenvolvimento passariam a ser explicitamente garantidas pelos governos dos países industrializados. Rohatyn estimava que, desta forma, os países devedores conseguiriam limitar seus pagamentos a no máximo $30 \%$ de suas exportações (Wertman, 1987a, pp. 126-127).

O senador Charles Schumer (democrata de Nova York) defendeu uma abordagem na qual os bancos poderiam optar por continuar a emprestar "dinheiro novo" nas bases vigentes, ou conceder alívio na forma (i) perdão de parte da dívida, (ii) redução de juros, (iii) troca de dívida por patrimônio (debt-equity swap) ou (iv) uma combinação dos anteriores (U.S. Senate, 1987b, p. 233). A idéia era liberar os bancos menores das limitações impostas pelos comitês liderados pelos money center banks. Como os bancos menores mostravam maior disposição para assumir perdas com as dívidas soberanas (e, ao mesmo tempo, mostravam pouca vontade de continuar a conceder crédito aos países em desenvolvimento), Schumer calculava que sua proposta poderia fazer com que até $20 \%$ da dívida fosse tratada "de forma diferente" (ibidem, p. 234). 
Mas o principal proponente de um esquema de alívio da dívida era o próprio senador Bill Bradley, que apresentou uma proposta detalhada em uma conferência em Zurique em 29 de junho de 1986 (Wertman, 1987a, p. 133). A proposta de Bradley era oferecer aos 15 países mais endividados, por 3 anos, uma redução média anual de 3 pontos percentuais nas taxas de juros, um corte médio anual de $3 \%$ em todas as dívidas comerciais e bilaterais ${ }^{87}$ pendentes e US\$ 3 bilhões em novos financiamentos por parte das instituições multilaterais. Os patamares exatos de reduções deveriam ser negociados caso a caso, tendo como contrapartida compromissos dos países devedores em liberalizar suas políticas comerciais, aumentar a poupança interna, reverter a fuga de capitais e promover o crescimento econômico. O alívio da dívida seria obrigatório, ou seja, os bancos credores seriam forçados a participar para evitar o problema da carona (Wertman, 1987a, pp. 133-134).

Caso levado adiante, a Proposta Bradley representaria um custo considerável para os bancos. Partindo-se de uma estimativa de que as dívidas dos 15 países mais endividados somavam US\$ 280 bilhões (Wertman, 1987a, p. 135), reduções anuais sucessivas de 3\% ao ano representariam uma diminuição de US\$ 24,4 bilhões. Como cerca de um terço das dívidas estavam em mãos de bancos norte-americanos, o custo para o sistema bancário norteamericano seria de cerca de US\$ 8 bilhões, ou 7,3\% de seu capital. Este custo se concentraria nos money center banks, que detinham a maior parte dos créditos soberanos. Ademais, outros prejuízos adviriam do corte nas taxas de juros.

Dentre os defensores do alívio da dívida, ademais, alguns depoentes pediam mudanças na regulação bancária norte-americana, para incentivar os bancos a adotar abordagens inovadoras. Tais mudanças seriam uma iniciativa puramente doméstica dos EUA, decidida pelo Congresso e colocada em prática por meio de legislação. Um exemplo deste argumento foi apresentado por Paul Sacks, da Multinational Strategies:

Os Estados Unidos precisam modernizar suas práticas de regulação. [...] O emergente mercado secundário da dívida existe para converter empréstimos de bancos comerciais em vários instrumentos novos que se parecem mais com títulos do que com empréstimos e que podem ser comercializados com mais liberdade. Temos que criar um regime regulatório para o mercado secundário para permitir que ele se desenvolva. [...] A estrutura regulatória que governa a carteira de dívida do Terceiro Mundo em mãos dos bancos comerciais concerne quase que exclusivamente empréstimos. O conjunto de instituições que atualmente governa os empréstimos comerciais inibiu a transformações destes empréstimos em ativos com maior liquidez ${ }^{\text {xlviii }}$. (U.S. House, 1987b, p. 276).

\footnotetext{
${ }^{87}$ Por "bilaterais", refiro-me às dívidas contraídas pelos países devedores diretamente com os governos dos países industrializados. Esta categoria não inclui as dívidas "multilaterais", ou seja, as contraídas junto a organizações internacionais (FMI e Banco Mundial).
} 
A posição dos grandes bancos, por seu turno, foi apresentada nos depoimentos de Jack Guenther, vice-presidente sênior para Operações Internacionais do Citibank, em 3 de março e $1^{\circ}$ de abril. Guenther atacou as propostas de estratégias alternativas para a crise da dívida: "eu e meus colegas do Citibank acreditamos que a maioria destas idéias são falhas ou exageradas ou simplesmente erradas e julgamos que se as políticas fossem baseadas nestas idéias elas teriam um efeito negativo sobre o financiamento privado" (U.S. Senate, 1987b, p. 100). Segundo ele, esquemas de perdão ou alívio do serviço da dívida iriam "adiar indefinidamente" o retorno dos fluxos de crédito para os países devedores. Isto só seria obtido, segundo ele, se os países devedores adotassem "boas políticas" para gerir suas economias:

[A adoção de] políticas corretas nos países em desenvolvimento é essencial. Não há solução sem isso. Qualquer sugestão de que negociações políticas, ou novas instituições, ou qualquer outra fórmula - não importa o quão interessante possa parecer em abstrato possa dispensar os países da necessidade de seguir boas políticas é contraproducente. Qualquer solução para o problema da dívida deve ser projetada de forma a promover melhores políticas públicas ${ }^{\text {xlix }}$. (U.S. House, 1987b, p. 53).

Guenter também procurou refutar o argumento de que a crise da dívida teria sido causa importante do déficit comercial: "claramente temos um desequilíbrio, mas as raízes deste desequilíbrio têm pouco a ver com o problema da dívida" (ibidem). Argumentou que a deterioração das contas externas dos EUA ocorrera com relação a todos os principais parceiros: entre 1980 e 1986, “o déficit com o Japão cresceu US\$ 42 bilhões, com a Europa Ocidental US\$ 50 bilhões, com o Canadá US\$ 17 bilhões, com os novos países industrializados da Ásia US\$ 23 bilhões, e com a América Latina US\$ 15 bilhões" (ibidem). Acusou os defensores de esquemas de alívio de dívida de "superestimar os problemas" relativos à dívida, afirmando que, em 1986, o déficit comercial dos EUA com a América Latina como um todo fora menor do que o déficit com Taiwan ${ }^{88}$. "A solução do problema de pagamentos externos dos EUA está em restaurar nossa competitividade frente ao Japão, à Alemanha e a outros países", afirmou (ibidem, p. 54).

Os depoimentos também mostraram que os bancos regionais tinham menos disposição para defender a continuidade da Estratégia dos Cinco Pontos do que os money center banks. Charles Coltman, vice-presidente executivo do Philadelfia National Bank, foi claro quanto a isso. "O processo atual”, admitiu o executivo, "foi extremamente útil em seu início, em 1982

\footnotetext{
${ }^{88}$ De fato, segundo o US Census Bureau (www.census.gov, acesso em 18/01/2010), o déficit comercial dos EUA com Taiwan em 1986 atingiu US\$14,3 bilhões, enquanto o déficit com a América Latina somou US\$11,4 bilhões.
} 
e 1983", pois "evitou uma crise que poderia ter sido muito mais séria". Cinco anos depois, no entanto, o processo servia apenas para perpetuar "uma ficção de que os empréstimos estão sendo honrados e que os juros estão em dia”. Havia espaço, segundo Coltman, para algum alívio das dívidas, pois os sistemas bancários "tiveram tempo para se ajustar" (U.S. Senate, 1987b, p. 92). Por isso, a opinião do Philadelfia National Bank era que "a dívida dos países em desenvolvimento deve começar a ser tratada da forma como é tratada a maioria dos emprestadores que se tornam insolventes" (ibidem, p. 93). Coltman, por fim, defendeu o estabelecimento de um mercado secundário forte, e informou que seu banco já havia vendido, nos últimos três anos, cerca de US\$ 50 milhões em empréstimos soberanos, assumindo perdas de US\$ 15 milhões sobre o valor de face dos créditos vendidos (ibidem, p. 92)

A posição do governo norte-americano era quase totalmente alinhada com a dos grandes bancos. David Mulford, que depôs perante três subcomissões diferentes nos dias 3, 4 e 26 de março representando o Departamento do Tesouro, assumiu a defesa do Plano Baker, afirmando que ele obtivera "progresso considerável" ao concentrar-se em promover o crescimento nos países devedores (U.S. House, 1987b, p. 25). Ao contrário de Guenther, Mulford admitiu que a crise "claramente teve um impacto sobre o comércio dos EUA" (ibidem, p. 259). Justamente em função deste impacto, o governo, a partir de 1985, teria passado a enfatizar a necessidade de os países endividados retomarem o crescimento econômico. Disto decorria a rationale para o Plano Baker.

Em todos os seus depoimentos, Mulford criticou diretamente as propostas que visavam a conceder algum alívio da dívida para os países em desenvolvimento. Segundo o argumento do Tesouro, estratégias de alívo da dívida causariam grandes prejuízos aos bancos, o que os levaria a retirar-se definitivamente do mercado de crédito para o Terceiro Mundo. Os países devedores, assim, veriam-se desprovidos de fontes privadas de financiamento, o que seria pior, a longo prazo, do que manter a estratégia vigente de gerar superávits comerciais para pagar os serviços da dívida já contraída. A solução para a crise da dívida, segundo Mulford, não viria de alívio da dívida, e sim por meio da adoção, pelos países devedores, de reformas econômicas de caráter liberalizante. Por isso, Mulford argumentava que a estratégia que o governo vinha adotando até então era a mais realista e que possuía maior credibilidade.

Num reflexo do desconforto da nova legislatura com o Plano Baker, os argumentos de Mulford foram questionados asperamente por diversos congressistas, e o Tesouro chegou a ser acusado de atuar apenas em defesa dos bancos. O questionamento de Mulford pelo 
deputado Joseph Kennedy (democrata de Massachusetts), em 3 de março, ilustra o clima negativo encontrado pelo Tesouro no Congresso:

KENNEDY: Você acha que a situação está boa neste momento?

MULFORD: Eu não disse que a situação estava boa, mas dada...

KENNEDY: Sua estratégia está funcionando bem.

MULFORD: ...mas dada a complexidade da situação eu creio que nossa estratégia está funcionando bem.

KENNEDY: Esta discussão está ficando complicada.

MULFORD: Eu não vejo outro plano na mesa, Sr. Kennedy, que seja aceitável para todas as partes [que serão afetadas] e elas estão preparadas para operar sob a atual estratégia da dívida e estão fazendo isso.

KENNEDY: Mas sua definição de partes não inclui os países do Terceiro Mundo nem os milhões de empregos que foram deslocados aqui. O que estamos realmente falando aqui é do interesse dos bancos; estou correto?

MULFORD: Não, estamos falando de todas as partes, ou seja os próprios países devedores [...], as instituições financeiras internacionais e os bancos comerciais. ${ }^{1}$.U.S. House, 1987b, p. 33.)

A posição de Paul Volcker repetia a do Tesouro. Em seu depoimento, Volcker também criticou a proposta de se estabelecer uma autoridade para intermediar a compra de dívida a valor de mercado e repassar os descontos aos países devedores:

Eu presumi, correta ou incorretamente, que este não é um caminho muito prático, que os Estados Unidos e outros parlamentos não iriam oferecer uma garantia pública ou fundos públicos diretos.

Eu também acho que temos um outro problema, mais amplo e filosófico, quanto à necessidade ou conveniência de perdoar esses empréstimos e se isso é no geral uma boa jogada para o progresso dos mercados financeiros internacionais, uma boa jogada para o crescimento e a prosperidade dos próprios países devedores que, creio eu, serão dependentes de acesso a capitais externos não apenas agora, mas no longo prazo. Será que realmente facilitamos isso com esse tipo de arranjo que envolve um tipo de cancelamento forçado ou semiforçado dos empréstimos? Nós não consideramos que isto seja muito útil li . (U.S. Senate, 1987b, p. 372).

Perguntado diretamente se sua oposição a esquemas de alívio da dívida coincidia com a de James Baker, Volcker não hesitou: "eu penso que em muitos casos, sim. É o que eu tenho dito. É muito complicado saber se este tipo de abordagem é produtivo ou contraprodutivo" (U.S. Senate, 1987b, p. 374).

Volcker também ressaltou seu apoio às instituições multilaterais: "é terrivelmente importante que vocês apóiem as instituições existentes que estão assumindo um papel absolutamente crítico neste processo", em particular o Banco Mundial e o BID. Segundo 
Volcker, "se estas instituições não forem apoiadas adequadamente, teremos perdido um elemento crítico para tratar deste problema" (U.S. Senate, 1987b, p. 373).

Com relação ao impacto da crise da dívida sobre o comércio internacional dos EUA, Volcker praticamente repetiu o argumento de Jack Guenther. Segundo Volcker, o aumento do déficit comercial com os países da América Latina "simplesmente não é [...] a explicação principal para o total de nosso déficit comercial", pois "a América Latina não é tão grande". "Quando temos um déficit comercial de US\$ 150 bilhões, os US\$ 15 bilhões de déficit com a América Latina só explicam 10 porcento do déficit” (U.S. Senate, 1987b, p. 375). Por isso, Volcker propôs que se mudassem os termos do debate, porque o desequilíbrio comercial estaria "entre os países industrializados": “uma das coisas que gostaríamos de ver [...] é que mais exportações da América Latina fossem para o resto do mundo e relativamente menos para nós, e mais de suas importações viessem de nós e menos do resto do mundo", pois os EUA teriam absorvido "uma parcela desproporcional" dos ajustes comerciais que os países devedores foram obrigados a realizar (ibidem, p. 374).

Por fim, confrontado diretamente com comentários de Charles Coltman, do Philadelphia National Bank, sobre a possibilidade de aumento da inadimplência dos países devedores, Volcker deixou clara a existência de um conflito com os bancos regionais: "eu não concordo com a observação [de Coltman] em termos gerais, mas na medida em que os bancos regionais se recusarem a participar destes pacotes [de financiamento] eles podem causar este resultado",lii (ibidem, p. 376).

\section{Tramitação da H.R. 3}

Como resultado dos debates, o texto da H.R. 3 aprovado na Câmara abandonou o apoio implícito da H.R. 4800 ao Plano Baker. Ao contrário, o novo dispositivo determinava a criação de uma Autoridade para o Gerenciamento da Dívida Internacional (International Debt Management Authority, IDMA), baseada na proposta de Bill Bradley. O texto também determinava que o Secretário do Tesouro analisasse formas de utilizar recursos do FMI e do Banco Mundial para financiar a IDMA. O projeto foi aprovado com folga (290 a 137 votos) na Câmara em 30 de abril de 1987.

O projeto demorou mais para tramitar no Senado, sendo aprovado em 21 de julho por margem ainda maior do que na Câmara (71 a 27 votos). A versão do Senado, no entanto, era mais branda no tocante à legislação sobre a crise da dívida. Ao invés de determinar que o 
governo deveria dar início a negociações com vistas à criação da IDMA, o texto aprovado no Senado estipulava que, antes de iniciar as negociações, o Secretário do Tesouro deveria realizar um estudo para determinar a pertinência e a viabilidade da nova organização, que só seria criada se os resultados do estudo não fossem desfavoráveis. A legislação também obrigava o Secretário do Tesouro a apresentar as conclusões preliminares do estudo, por meio de relatório a ser enviado ao Congresso, seis meses depois da entrada em vigor da lei.

Aprovada com relativa rapidez nas duas casas, a H.R. 3 teve lenta tramitação na comissão de conferência, em parte devido ao tamanho e à complexidade do projeto. Em função do clima de crescente confronto entre Congresso e Executivo sobre os temas comerciais, os congressistas buscaram chegar a um texto que contasse com amplo apoio dos dois partidos, e portanto à prova de veto presidencial.

No que tange às medidas para a crise da dívida, a versão do Senado prevaleceu na comissão de conferência, em grande medida por pressão direta do próprio Tesouro, que repetidamente ameaçava vetar a H.R. 3 se certos dispositivos fossem incluídos. Em particular, autoridades do Tesouro ameaçavam explicitamente que, se o projeto de lei ordenasse o governo a negociar com outros países a criação de uma IDMA, ele seria vetado pelo presidente (Farnsworth, 1988).

A comissão de conferência encerrou seus trabalhos no final de abril de 1988, e nos dias seguintes as duas casas aprovaram em plenário o projeto final. Em 24 de maio, no entanto, o presidente Reagan vetou a H.R. 3, devido a um dispositivo que obrigava o anúncio antecipado, por parte das empresas, de fechamento de fábricas e de demissões em massa (Farias, 2007, p. 99). O projeto foi reintroduzido em julho, sem este dispositivo, como H.R. 4848. O novo projeto, que mantinha os dispositivos relativos à crise da dívida do H.R. 3 (inclusive a IDMA), foi aprovado por maiorias à prova de veto em ambas as casas (376 a 45 na Câmara, 85 a 11 no Senado), e foi sancionado por Reagan em 23 de agosto de 1988, como Public Law 100-418.

\section{Novas tentativas de Baker de tomar a iniciativa política}

Enquanto o Congresso discutia a adoção de medidas que modificavam a abordagem do governo para a crise da dívida, James Baker tentaria repetir a tática de 1985 para reassumir a iniciativa política, anunciando, em abril e setembro de 1987, novos planos para a gestão da crise. Desta feita, no entanto - e refletindo o crescente desgaste do governo na matéria - , os 
anúncios não surtiriam o efeito de paralisar ou mesmo alterar o foco das discussões no Legislativo.

No discurso proferido na reunião semestral do Comitê Interino do FMI de abril de 1987, Baker exortou os bancos credores a desenvolverem um "menu de opções alternativas de dinheiro novo" (Parola, 1991, p. 118). O chamado menu approach permitia que várias das propostas em circulação de soluções alternativas para a crise fossem incorporadas como opções em processos de renegociações de dívidas. Desta forma, cada banco poderia optar por converter parte de seus créditos com um país em títulos ou ativos deste país, ou mesmo oferecer reduções nos juros ou no montante da dívida.

A despeito de incorporar diversas idéias em discussão no Congresso, o menu approach não foi considerado uma alternativa viável para solucionar a crise da dívida. Ficou evidente, desde sua apresentação, que o próprio caráter voluntário do menu de opções tornava-o pouco efetivo, pois cada banco credor poderia selecionar os mecanismos que desejasse - ou não selecionar nenhum -, estritamente de acordo com seus interesses particulares. Como mostrou Shafiqul Islam, o menu approach oferecia redução de dívida marginal e sem coordenação (U.S. Senate, 1988). Com uso limitado e sem contar com mecanismos de coordenação, o menu de opções desde cedo foi tido como uma abordagem inviável para reduzir substancialmente a dívida dos países em desenvolvimento.

No final de setembro, no encontro anual do FMI e do Banco Mundial, James Baker apresentaria mais uma nova idéia para a gestão da crise da dívida. Desta vez, Baker propôs criar uma nova linha de crédito do FMI para proteger os devedores de acontecimentos imprevistos, "como queda dos preços das commodities, redução dos volumes de exportação, desastres naturais e aumento permanente das taxas de juros" (Truell, 1987c, grifo meu). A inclusão de aumento permanente de juros como um acontecimento imprevisto cujos custos deveriam ser cobertos por empréstimos do FMI tinha o efeito de reduzir o risco dos bancos, pois eventuais aumentos de juros seriam cobertos por fundos oficiais.

É bastante relevante, também, que no centro da nova proposta de Baker encontrava-se, mais uma vez, o FMI. Seu discurso, de fato, parecia uma nova tentativa de reter a iniciativa política sobre a crise da dívida - iniciativa que o Congresso procurava assumir, por meio do projeto H.R. 3 - e manter o FMI no centro das negociações.

No entanto, este discurso de James Baker foi ainda menos longe do que o de abril. A iniciativa foi imediatamente criticada como algo irrealista e que não resolvia os problemas de 
fundo. "É um salvamento de bancos, puro e simples", acusou Martin Mayer. "Eles obtêm maiores pagamentos de juros; os países devedores não obtêm nada; e ao final o problema não está mais próximo de uma solução do que estava no começo", afirmou. Por fim, argumentou que tal proposta não seria factível porque a probabilidade de o Congresso autorizar "dinheiro para ajudar o FMI a pagar os aumentos das contas de juros dos devedores externos" era "próxima de zero" (Mayer, 1987). A idéia seria esquecida e desapareceria dos jornais em poucos dias.

O episódio ilustra a erosão da iniciativa política do Tesouro, num contexto em que o próprio Congresso tornava-se o principal proponente de estratégias alternativas para a crise da dívida.

\section{O aumento do capital do Banco Mundial}

A postura mais assertiva do Congresso com relação à política para a dívida externa foi determinante na reação do Legislativo à proposta do Executivo de aumentar o capital do Banco Mundial. Neste episódio, um grupo de congressistas democratas condicionou a aprovação de mais recursos para o Banco à adoção de mudanças na estratégia para a crise da dívida, e logrou paralisar a tramitação da proposta até a aprovação da H.R. 4848.

Em fevereiro de 1988, os países-membros do Banco concordaram em aumentar seu capital em cerca de US\$ 74,8 bilhões nos seis anos seguintes (Globe and Mail, 1988a). Como a instituição se financia junto ao setor privado, apenas $3 \%$ desse montante deveria ser integralizado em dinheiro pelos países-membros. O restante deveria ser aportado por meio de capital callable, ou seja, recursos que só seriam desembolsados caso o Banco se visse na improvável situação de não conseguir levantá-los junto ao setor privado. Desta forma, os EUA, com 18,75\% do poder de voto do Banco, deveriam, nos seis anos seguintes, transferir anualmente à instituição US\$ 70,1 milhões e aumentar seu comprometimento em capital callable em US\$ 2,3 bilhões (Rowen, 1988b, 1988e). O capital callable nunca tinha sido requisitado pelo Banco, que gozava da melhor classificação de crédito possível no mercado financeiro (Globe and Mail, 1988b). De acordo com a legislação norte-americana, somente os montantes efetivamente desembolsados seriam incorporados ao orçamento federal (Rowen, 1988c). Portanto, dada a baixíssima probabilidade de que o capital callable viesse a ser requisitado pelo Banco, a proposta de aumento de capital da instituição representava um aumento insignificante dos gastos públicos. 
O pedido de recursos para integralizar a parte norte-americana foi apresentado ao Congresso em março de 1988, por meio do projeto H.R. 4645. Apesar de representar um pequeno desembolso de recursos, o pedido foi imediatamente recebido com hostilidade. Como de hábito, os congressistas conservadores trataram a proposta com a desconfiança usual a qualquer forma de ajuda internacional (International Banking Report, 1988a). A novidade foi a reação dos democratas, muitos dos quais decidiram se opor ao pedido a não ser que o governo aceitasse incluir na H.R. 3, que ainda estava em tramitação, dispositivos de concessão de alívio da dívida aos países em desenvolvimento. "Eu não vou votar a favor de um centavo sequer a não ser que a Administração Reagan aceite o alívio da dívida como um componente de sua estratégia para a dívida", afirmou o deputado John LaFalce (democrata de Nova York). De fato, a coalizão que se opôs ao aumento do capital do Banco incluía conservadores e liberais e era liderada por deputados democratas que tradicionalmente apoiavam a instituição - mas que, naquele momento, priorizavam a adoção de medidas de alívio da dívida e viam o aumento de recursos à disposição do Banco como uma forma de se evitar uma solução definitiva para o problema da dívida. "Não há como separar a dívida do Terceiro Mundo do aumento de capital [do Banco]", afirmou o deputado Bruce Morrison (democrata de Connecticut). "Qual é o sentido de empilhar dívida sobre dívida que os países nunca podem pagar? No final arriscamos o Banco Mundial a não receber o que deve", questionou. (Farnsworth, 1988). Sem o apoio dos deputados liberais, seria impossível aprovar a proposta, pois os congressistas conservadores eram tradicionalmente hostis ao Banco.

Apesar da disputa no Congresso, o aumento de capital do Banco entrou em vigor no final de abril, quando obteve aprovação de países-membros cujas participações somavam 75\% dos votos na instituição (Globe and Mail, 1988b). Desta forma, os EUA se viram arriscados a ver sua participação no Banco ser diluída - e seu poder de voto, reduzido - caso não aprovassem o aumento de capital. Ao mesmo tempo, a aprovação do aumento pelos outros países-membros podia ser usada como instrumento de pressão junto ao Congresso.

A possibilidade de que a inação do Congresso levasse à redução do poder de voto dos EUA no Banco levou James Baker a intensificar as críticas a seus opositores. "[Os democratas] querem gastar bilhões para resolver o problema da dívida do Terceiro Mundo com dinheiro do contribuinte, mas não querem gastar US\$ 70 milhões para aumentar o capital do Banco Mundial", acusou em entrevista concedida ao Washington Post. Segundo Baker, a maneira certa de tratar o problema da dívida era fortalecer o Banco Mundial, para que ele 
financiasse a adoção de "reformas orientadas ao crescimento" por parte dos países devedores (Rowen, 1988c). A entrevista de Baker enfureceu os democratas, que o acusaram de distorcer a posição do partido (Rowen, 1988d). Poucos dias depois, Baker teve uma áspera discussão com o presidente da Subcomissão de Operações Exteriores da Comissão de Apropriação da Câmara, Dave Obey (democrata de Wisconsin), durante uma audiência pública. "A política do governo está jogando o ônus das conseqüências do excesso de dívida do Terceiro Mundo sobre os setores da sociedade não relacionados à comunidade financeira, ou seja a manufatura e a agricultura",liii , acusou o deputado. Obey defendeu a adoção de um plano de alívio da dívida e afirmou que, sem tal plano, o Congresso não aprovaria o aumento de capital do Banco. Baker respondeu afirmando repetidamente que o governo se opunha a "soluções generalizadas" para o problema da dívida, que representavam "um golpe ao contribuinte". Obey replicou imediatamente que o maior "golpe ao contribuinte" era o aumento de capital do Banco, e afirmou não ver "nenhuma possibilidade de que esta comissão, ou mesmo a Câmara, aprove o aumento de capital do Banco enquanto este impasse sobre a dívida do Terceiro Mundo continuar"liv (International Banking Report, 1988b).

O conflito com Baker e o veto de Reagan à H.R. 3 levaram os democratas a concluir que seria melhor manter a tramitação do pedido do Tesouro parada na Comissão de Bancos da Câmara, à espera da posse do novo presidente, do que negociar com um governo em fim de mandato (International Banking Report, 1988c). O Tesouro então adotou o discurso de que, dado que o aumento de capital do Banco já tinha entrado em vigor, a recusa dos EUA em integralizar sua parte dos recursos seria "catastrófica" para a credibilidade internacional do país e o levaria a perder o poder de veto de que ele dispõe na organização. "É extremamente importante preservar o veto, o qual nos dá influência sobre a instituição", defendeu Baker em uma longa e difícil audiência à comissão de Bancos da Câmara (Rowen, 1988e). O próprio presidente do Banco Mundial, Barber Conable, que fora deputado antes de assumir o cargo, pediu diretamente ao Congresso que aprovasse o aumento de capital, utilizando os mesmos argumentos de Baker (New York Times, 1988). Os jornais passaram a publicar cartas e editoriais pedindo que o Congresso aceitasse o pedido do Tesouro ${ }^{89}$, e o Bretton Woods

\footnotetext{
${ }^{89}$ Cf. Washington Post (1988a, 1988b), Christian Science Monitor (1988), Fowler, Walker e Owen (1988), Klutznick (1988). Um dos argumentos mais curiosos foi apresentado por Martin Koelle, morador de um subúrbio ao norte de Washington: se os EUA deixassem seu poder de voto diminuir e o país deixasse de ser o principal acionista do Banco, este teria, por força de seus estatutos, de mudar-se para o território de seu principal acionista, deixando Washington. Isto teria graves conseqüências para a economia da região, já que as despesas administrativas da sede do Banco chegavam a US\$ 500 milhões anuais. Cf. Koelle (1988).
} 
Committee - uma organização de lobby cujo trabalho é defender as instituições financeiras multilaterais em Washington — organizou uma conferência com Paul Volcker e publicou cartas de três ex-presidentes e de nove ex-secretários do Tesouro em apoio ao aumento do capital (Dunne, 1988). Note-se que o fato de o aumento de capital já ter sido aprovado pelos outros países-membros do Banco servia como argumento para convencer o Congresso a fazer o mesmo. O governo jogava, assim, as cartas da reputação internacional e da necessidade de manter a influência dos EUA na organização como argumento para convencer os congressistas a votar a favor do aumento.

A aprovação da H.R. 4848, que incluía os dispositivos exigidos pelos democratas (embora de forma menos contundente do que a pedida pelos democratas da Câmara) e que foi sancionada por Reagan em 23 de agosto, abriu caminho para que as negociações sobre o aumento de capital do Banco fossem retomadas. Na segunda quinzena de setembro, a Comissão de Bancos da Câmara aprovou a H.R. 4645, que autorizava os EUA a contribuírem com o aumento de capital do Fundo nos moldes solicitados pelo governo.

No entanto, a exemplo do que ocorrera com o aumento de capital do FMI em 1983, a aprovação do aporte de capital ao Banco só foi possível graças a uma manobra legislativa. Num caso evidente de logrolling, os defensores da H.R. 4645, temendo que ela fosse derrotada no plenário, preferiram incorporar seu conteúdo à H.R. 4637, a lei de apropriação de fundos para ajuda internacional que, depois de vários meses de negociações, chegara à comissão de conciliação. A H.R. 4637 apropriaria mais de US\$ 14 bilhões para diversas agências e, portanto, sua aprovação era muito mais garantida do que a da H.R. 4645. A manobra foi duramente questionada pelos opositores do aumento de capital do Banco, que apresentaram uma emenda ao Senado que visava a excluir os dispositivos da H.R. 4645 do texto da H.R. 4637. Em 30 de setembro — último dia do ano fiscal de 1988 - , a emenda foi votada no plenário do Senado e foi derrotada por 57 a 34 votos. No dia seguinte, a H.R. 4637 foi sancionada por Reagan e tornou-se a Public Law 100-461.

Mesmo assim, os congressistas fizeram questão de sinalizar sua insatisfação com a estratégia do governo para crise da dívida: na linguagem incorporada pela comissão de conciliação na H.R. 4637, foram autorizados, para o ano fiscal de 1989, US\$ 20 milhões a menos do que os US\$ 70,1 milhões solicitados pelo governo. Ademais, a lei determinava que o Secretário do Tesouro deveria "instruir o diretor executivo dos Estados Unidos do Banco Internacional para Reconstrução e Desenvolvimento a iniciar discussões com outros diretores 
do banco e defender e apoiar a facilitação de programas voluntários de mercado pra a redução da dívida soberana" (Farias, 2007, pp. 101-102) lv $^{\mathrm{l}}$ "Não queríamos enviar um sinal de que os Estados Unidos estão reduzindo seu interesse no Banco", explicou David Obey. "Queríamos sinalizar que não estamos satisfeitos com a política para a dívida que está sendo seguida", afirmou (Cranford e Felton, 1988).

\section{O bloqueio do governo ao aumento de capital do FMI}

A oposição do Congresso norte-americano à estratégia vigente para a dívida também contribuiu para levar o governo norte-americano a bloquear o aumento do capital do FMI marcado para 1988. Tradicionalmente, as revisões da composição de capital do Fundo se dão a cada cinco anos; como a oitava revisão ocorrera em 1983, a nona revisão deveria ser concluída em 1988. No âmbito do FMI, os trabalhos com vistas a esta revisão começaram em março de 1987, mas desde o início os representantes norte-americanos mostraram-se pouco favoráveis. Em setembro, todos os diretores executivos manifestaram-se dispostos a aprovar um aumento de pelo menos $50 \%$ do capital do Fundo, com exceção dos diretores executivos dos EUA e do Reino Unido (Boughton, 2001, p. 870-871).

Em janeiro de 1988, Camdessus declarou julgar necessário aumentar o capital da organização, ao que o Tesouro se apressou a vazar informações para a imprensa dando conta de sua oposição à proposta (Rowen, 1988a). Em setembro, Camdessus voltou à carga e sugeriu que o capital do Fundo fosse aumentado em no mínimo 50\% e, se possível, em 100\%. Poucos dias depois, durante a reunião conjunta do FMI e do Banco Mundial em Berlim Ocidental, Nicholas Brady, que sucedera James Baker como secretário do Tesouro apenas duas semanas antes, proferiu um discurso duro no qual afirmou que os EUA eram contrários a qualquer aumento de capital da organização. "Em um momento de demandas conflitantes e restrições orçamentárias, o argumento a favor de recursos adicionais para quotas tem que ser muito convincente", afirmou Brady. "Deveria haver uma [...] necessidade comprovada de fundos, não apenas uma pressuposição de que mais é melhor"lvi (Greenhouse, 1988).

Duas razões parecem ter levado o governo dos EUA a bloquear o aumento de capital do Fundo. A explicação mais comum, à época, foi a existência de um conflito entre o FMI e o Tesouro. Desde sua posse como diretor-gerente, em janeiro de 1987, Michel Camdessus vinha mostrando disposição de aumentar a autonomia do FMI no tratamento da questão da dívida. Especificamente, Camdessus via com simpatia as idéias de alívio da dívida, às quais o 
Tesouro mantinha oposição cerrada. Ao mesmo tempo, outros governos de países industrializados também começavam a considerar a posição do Tesouro rígida demais. Em junho de 1988, o ministro das Finanças do Japão, Kiichi Miyazawa, apresentou as linhas gerais de uma proposta segundo a qual parte da dívida dos países em desenvolvimento seria trocada por títulos garantidos com desconto no valor de face. As garantias seriam fornecidas pelo FMI, cujo capital seria ampliado. A proposta, conhecida como Plano Miyazawa, ganhou espaço nas semanas subseqüentes, mas foi abatida por Brady em Berlim. Segundo o novo secretário do Tesouro, Washington "vê com ceticismo propostas que podem parecer estar de acordo com os princípios básicos da estratégia da dívida, mas que na prática produzem apenas uma ilusão de progresso" (Greenhouse, 1988). Neste momento, David Mulford já trabalhava em proposta semelhante (Cline, 1995), o que indica que a oposição dos EUA a propostas de outros países industrializados devia-se menos ao conteúdo das propostas do que ao interesse em evitar que outro país ou organização assumisse um papel de liderança no tema da dívida.

O outro fator que explica o bloqueio é a dinâmica política interna norte-americana. Como o capital do FMI à época era de cerca de US\$ 115 bilhões, um aumento de 50\% obrigaria os EUA a contribuir imediatamente com US\$ 11 bilhões (Greenhouse, 1988). À luz das dificuldades que o governo teve para obter US\$ 400 milhões, escalonados em seis anos, para o Banco Mundial, pode-se supor que o governo julgasse impossível obter quase 30 vezes mais recursos para o FMI. Em abril de 1987, o próprio James Baker afirmou, em reunião do Comitê Interino, acreditar que o aumento de capital não era "nem financeiramente necessário nem politicamente factível' naquele momento (Boughton, 2001, p. 870, grifo meu). Por fim, as eleições gerais de 1988 impossibilitaram que o assunto fosse adiante naquele ano, pois não era de interesse do governo norte-americano - cujo vice-presidente, George Bush, seria candidato à presidência - que a questão da dívida se tornasse um tema da campanha.

No nível doméstico, repetia-se o que ocorria no nível externo: não interessava ao governo abrir espaço para que outros atores aumentassem sua influência - e muito menos que assumissem a liderança - no tema. Apresentar um pedido de aumento do capital do FMI tornaria ainda mais acaloradas as discussões sobre a própria estratégia para a dívida externa, já que a H.R. 3 - que tramitava pelo Congresso e que incluía instruções para que o governo iniciasse negociações para criar uma agência internacional para comprar a dívida externa dos países em desenvolvimento - baseava-se numa visão contrária à do governo sobre a questão. Nesse contexto, os congressistas provavelmente condicionariam o aporte de novos recursos 
para o FMI à adoção de mudanças na gestão da crise da dívida, forçando o governo norteamericano a escolher entre abrir mão de participar do aumento de capital (e reduzir sua participação no capital e seu poder de voto no Fundo) ou curvar-se às determinações do Legislativo.

O aumento do capital do Fundo ficou adiado, assim, para um momento em que o Executivo contasse com a iniciativa política sobre a questão da dívida. Como veremos, este momento viria nos meses seguintes à posse do novo presidente, quando à "lua-de-mel" que caracteriza todo começo de mandato presidencial se somaria um novo plano do Tesouro, que levaria em conta o desejo do Congresso de conceder alívio da dívida. Até lá, no entanto, o FMI continuaria a isolar o ambiente doméstico norte-americano das negociações com os países devedores, permitindo a continuidade da abordagem vigente desde 1982 para a dívida.

\subsection{O FMI E AS NEGOCIAÇÕES COM ARGENTINA, BRASIL E MÉXICO}

Enquanto o Congresso discutia a adoção de abordagens alternativas para a crise, o FMI continuava a negociar com os grandes países devedores nas bases estabelecidas pela Estratégia dos Cinco Pontos. Entre 1987 e o início de 1989, o Fundo assinou acordos ou liberou recursos para Argentina, Brasil, Chile, Costa do Marfim, Costa Rica, Equador, Iugoslávia, Jamaica, Marrocos, México, Nigéria e Venezuela, além de outros devedores menores (Boughton, 2001, pp. 402-403). A atuação do FMI - e, no caso do acordo com a Argentina em setembro de 1988, também do Banco Mundial - permitiu que a gestão da crise da dívida permanecesse dentro dos limites estipulados pelo governo dos EUA, a despeito das pressões oriundas do nível doméstico norte-americano e do interesse dos países devedores em obter melhores termos nas sucessivas negociações.

\subsubsection{ARgentina}

O acordo com a Argentina começou a ser negociado em setembro de 1986, em um contexto de deterioração econômica marcado por retorno da inflação e aumento do déficit fiscal. Os negociadores do FMI e da Argentina discordavam sobre o grau de austeridade que o país deveria buscar: o FMI pedia uma redução no déficit em conta corrente e na meta de inflação para níveis que o governo argentino julgava impraticáveis. Os negociadores argentinos solicitavam que o acordo incluísse cláusulas de contingência similares às do acordo com México, enquanto o FMI considerava que o acordo com o México havia sido 
excepcional e não queria que as cláusulas de contingência fizessem parte de outros acordos (Boughton, 2001, p. 466).

No começo de janeiro, os negociadores argentinos concordaram com as demandas do FMI e assinaram uma Carta de Intenções solicitando um empréstimo stand-by de cerca de US\$ 1,4 bilhão. O Conselho Executivo do Fundo aprovou o acordo no final de fevereiro. Como os recursos só seriam liberados depois que a Argentina fechasse um acordo com os bancos, foi necessário obter um empréstimo-ponte de US\$ 500 milhões dos principais países credores, por meio do BIS. O Fed liderou esta operação e participou com metade do montante total, usando o empréstimo stand-by com o FMI como garantia (Boughton, 2001, pp. 468469). A disposição do Fed de adiantar os recursos foi motivada, em grande parte, pelo receio de que a Argentina pudesse juntar-se ao Brasil e declarar moratória sobre sua dívida (Lehman e McCoy, 1991, p. 621). As negociações da Argentina com os bancos credores começaram em meados de fevereiro, e dois meses depois um acordo estava pronto para ser assinado. A adesão dos bancos ao acordo foi mais lenta do que o esperado pelo Comitê Assessor: em meados de junho, tinha sido fechado apenas $92 \%$ do pacote de financiamento. As metas estabelecidas pela Carta de Intenções assinada em janeiro não estavam sendo atingidas, mas mesmo assim o FMI decidiu iniciar a liberação de recursos (Boughton, 2001, pp. 469-470). Para tanto, as metas macroeconômicas foram revistas em julho e novo acordo foi assinado em agosto (Aggarwal, 1996, p. 437).

Em setembro, a União Cívica Radical — partido do presidente Raúl Alfonsín perdeu a maioria do Congresso nas eleições legislativas. Isto enfraqueceu ainda mais o governo, que se mostrava incapaz de cumprir as metas macroeconômicas estabelecidas na Carta de Intenções. Sob pressão do FMI, que ameaçava interromper a liberação de recursos para o país, o governo argentino anunciou novo pacote de medidas de austeridade em outubro. Dois dias depois, o Departamento do Tesouro dos EUA anunciou o início das negociações para conceder novo empréstimo-ponte de US\$ 500 milhões por meio do BIS (Boughton, 2001, p. 471).

O pacote anunciado pelo governo em outubro seria aprovado somente em janeiro de 1988, depois de ser modificado para atender a exigências da oposição. As metas macroeconômicas continuavam a não ser cumpridas e, para piorar, no final do mês o país deixou de pagar a parcela de uma dívida com o Fundo, colocando o país em atraso com a instituição pela primeira vez (Boughton, 2001, p. 473). O FMI bloqueou a liberação da 
terceira parcela de US\$ 225 milhões do programa stand by, o que significou o bloqueio de um empréstimo de US\$ 541 milhões por parte dos bancos (Aggarwal, 1996, p. 438). Para quebrar o impasse entre o país e o Fundo, o presidente Raúl Alfonsín encontrou-se pessoalmente com o diretor-gerente Michael Camdessus, em segredo. No encontro, Alfonsín concordou em adotar metas mais ambiciosas de redução do déficit fiscal, em troca do compromisso de Camdessus de ajudar a convencer os bancos credores a conceder-lhe alívio da dívida. Em fevereiro, novo acordo foi fechado, no qual o governo argentino se comprometia a reduzir o déficit fiscal para 2\% do PIB em 1988 e zerá-lo em 1989. O acordo foi finalmente aprovado pelo Comitê Executivo do Fundo em meados de março, e os recursos que estavam bloqueados foram liberados (ibidem, p. 438). No entanto, no final do mesmo mês a Argentina viu-se incapaz de manter em dia seus pagamentos aos bancos credores. Em junho, já estava claro que o déficit público ficaria ao redor de 5\%, e as autoridades argentinas julgavam impossível realizar qualquer ajuste se os bancos não concedessem uma forma de alívio da dívida que reduzisse os juros pagos pelo país. O FMI, no entanto, exigia que o governo realizasse um ajuste fiscal antes de buscar alívio da dívida - descumprindo, assim, a promessa que Camdessus fizera a Alfonsín poucos meses antes. Nesse contexto, o Fundo suspendeu seu programa com o país (Boughton, 2001, pp. 473-475, 520).

Em agosto, o governo argentino lançou o Plano Primavera, um pacote que incluía um pacto de congelamento de preços e salários, um aumento de $30 \%$ nas tarifas públicas e uma desvalorização preestabelecida do austral frente ao dólar à taxa fixa de $4 \%$ ao mês. Com vistas a obter um empréstimo de US\$ 1,2 bilhão, o governo argentino retomou as negociações com o Fundo em setembro, mas a instituição continuou insistindo em exigir uma forte redução do déficit público, uma condição impossível de ser cumprida pela Argentina.

Neste momento, o Tesouro tentou romper o impasse. O governo Reagan queria evitar que uma deterioração da situação financeira da Argentina comprometesse a credibilidade da sua estratégia para a crise da dívida às vésperas das eleições norte-americanas, que ocorreriam em novembro (Aggarwal, 1996, p. 441, Economist, 1989b, Lewis, 1988c). James Baker pediu diretamente a Camdessus que o Fundo flexibilizasse suas condições, mas este se recusou a ceder (Bougthon, 2001, pp. 521-522). Em privado, autoridades do Tesouro começaram a criticar Camdessus, acusando-o de usar a negociação com a Argentina para criar uma quedade-braço com o governo dos EUA e, desta forma, aumentar a autonomia do FMI na gestão da crise da dívida (Truell, 1988c). 
Como Camdessus se recusou a ceder, o Tesouro resolveu o problema sem o Fundo. Em 25 de setembro de 1988, a Argentina fechou um surpreendente acordo com o Banco Mundial para obter um empréstimo de US\$ 1,25 bilhão. O acordo com o Banco determinava metas macroeconômicas menos rígidas do que as exigidas pelo FMI, e representou uma novidade no relacionamento entre as duas instituições: até então, o Banco Mundial só emprestava para países que já possuíssem um acordo com o FMI em vigor. A despeito das negativas do Banco Mundial de que tenha recebido pressões do governo dos EUA, o acordo foi visto como a forma que o Tesouro encontrou para contornar a recusa de Camdessus e conceder o empréstimo à Argentina (Boughton, 2001, p. 523, Truell, 1988c, Hogg e WilsonSmith, 1988, Independent, 1988).

Numa única manobra, o Tesouro ao mesmo tempo evitou um colapso da economia argentina - que evidenciaria o fracasso de seu gerenciamento da crise da dívida - e reafirmou sua preponderância sobre o FMI. Uma semana antes do episódio argentino, Camdessus - que desde o início de seu mandato mostrara-se mais favorável a conceder alívio da dívida do que as autoridades norte-americanas - declarara que o tratamento do problema da dívida internacional "não [tinha sido] extremamente brilhante" no ano anterior (Truell, 1988c, Rodgers e Huhne, 1988). Depois do showdown com o governo norteamericano, no entanto, Camdessus apressou-se a declarar que não havia conflito com o Tesouro, e as críticas à gestão da crise da dívida acabaram.

De qualquer forma, o governo argentino também não conseguiu atingir as metas definidas com o Banco, e o programa foi interrompido depois da liberação da primeira parcela dos recursos, de US\$ 254 milhões (Economist, 1989a).

\subsubsection{BRASIL}

A saída de Bresser Pereira do Ministério da Fazenda encerrou o período de confrontação do governo brasileiro contra o FMI e os bancos credores. O Brasil retomou as negociações com o Comitê Consultivo já em dezembro de 1987, antes mesmo de declarar o fim da moratória. Em janeiro, Mailson da Nóbrega foi efetivado como Ministro da Fazenda e decidiu retomar o relacionamento com o Fundo. "O FMI não é nenhum bicho", afirmou o novo ministro. "Temos consciência da necessidade da volta ao FMI", admitiu. (Veja, 1988a, p. 76). No começo de fevereiro, o governo brasileiro fez um pagamento incondicional de US\$ 350 milhões referentes a juros vencidos em janeiro. $\mathrm{O}$ gesto brasileiro reabriu as negociações 
com os bancos credores, aos quais o governo brasileiro pedia um novo empréstimo de US\$ 7,1 bilhões para refinanciar juros vencidos e a vencer em 1988. Os bancos, no entanto, ofereceram apenas US\$ 4 bilhões e sugeriram que o Brasil buscasse o restante junto ao FMI e ao Banco Mundial (Veja, 1988b, p. 69). Ainda em fevereiro, Mailson viajou para Washington e encontrou-se com Michel Camdessus, Barber Conable e James Baker. O encontro com Camdessus foi particularmente importante porque marcou o reatamento de relações do País com o Fundo, que estavam rompidas há cerca de três anos. A seguir, Mailson viajou para Nova York e encontrou-se com os representantes dos bancos credores, que exigiram que o governo brasileiro concluísse um programa com o Fundo como condição para fechar um acordo (Aggarwal, 1996, p. 480).

No final de fevereiro, o governo brasileiro chegou a um acordo preliminar com os bancos, que concordaram em emprestar US\$ 5,8 bilhões para cobrir os pagamentos de juros entre 1987 e 1989 e em reescalonar cerca de US\$ 61 bilhões da dívida de longo e médio prazos. Em troca, o Brasil se comprometeu a pagar aproximadamente US\$ 700 milhões de juros vencidos em janeiro e fevereiro. Naturalmente, o acordo era condicionado a um entendimento do Brasil com o FMI (Aggarwal, 1996, pp. 491-492, Boughton, 2001, p. 529).

Nas semanas seguintes, a despeito da atitude cooperativa do Brasil, os bancos credores assumiram uma postura maximalista e passaram a exigir diversas condições que o governo brasileiro julgou excessivas, entre elas uma autorização expressa para o arresto das reservas brasileiras caso o País deixasse de pagar os juros da dívida em dia. O impasse levou o governo brasileiro a interromper as negociações em maio, chamando seus representantes de volta a Brasília (Veja, 1988c, p. 101). Como resultado, o Tesouro tentou mediar o conflito, pressionando os bancos a fazerem concessões (Truell, 1988a). O FMI juntou-se às pressões do Tesouro, e Michel Camdessus chegou a declarar publicamente que a estratégia de gestão da dívida estava sendo prejudicada pela quase ausência de novos empréstimos aos países em desenvolvimento e pela lentidão dos processos de renegociação das dívidas já existentes (Torday, 1988).

As pressões do governo norte-americano e do FMI sobre os credores privados eram motivadas, em grande parte, pela percepção de que a redução na exposição dos grandes bancos - que tinha se intensificado a partir do primeiro semestre de 1987, quando os money center banks aumentaram significativamente suas reservas contra perdas com dívidas aos países em desenvolvimento - havia reduzido o interesse dos próprios bancos em continuar 
financiando os países endividados para evitar que eles entrassem em default. Como afirmou E. Gerald Corrigan, president do Federal Reserve de Nova York, "de uma forma irônica e preocupante, o [...] financiamento privado se enfraqueceu em parte porque a exposição dos bancos foi reduzida tão dramaticamente"lvii (Truell, 1988b). Estimava-se que a exposição dos grandes bancos aos 15 países mais endividados (os "Baker 15") caíra de cerca de 250\% de seu capital em 1982 para menos de $90 \%$ ao final de 1987 - o que reduzira consideravalmente o risco que o endividamento dos países em desenvolvimento representava para o sistema bancário (The Wall Street Journal, 1988). Segundo Corrigan, era importante evitar que o "problema" da dívida voltasse a ser uma "crise" por falta de financiamento privado: "para evitar isso, precisamos de uma forte reafirmação do compromisso dos bancos credores com o projeto maior"lviii, declarou. (Truell).

O Brasil fechou um acordo com os bancos em junho. As condições exigidas do Brasil foram duras: o País se comprometeu a reduzir o déficit público de $7 \%$ para $4 \%$ do PIB e a pagar, até o final de junho, US\$ 1,35 bilhão em juros vencidos, em troca de US\$ 5,8 bilhões em "dinheiro novo" (Veja, 1988d). O acordo obteve a "massa crítica" de 95\% de adesão em agosto de 1988, e logo depois o FMI aprovou um crédito stand by de US\$ 1,4 bilhão (Aggarwal, 1996, p. 492, Boughton, 2001, p. 529). Em 23 de setembro, o pacote com o FMI foi assinado, e no dia seguinte o Brasil declarou estar encerrando oficialmente a moratória (Aggarwal, 1996, p. 493).

\subsubsection{MÉXICO}

O programa fechado no final de 1986 começou bem, mas no começo de 1987 a situação econômica voltou a se deteriorar. O país teve de pagar o empréstimo-ponte de US\$ 1,7 bilhão em fevereiro, antes de receber a primeira parcela do financiamento privado (de US\$ 3,5 bilhões), o que só ocorreu no final de abril de 1987. Por causa do atraso em receber o financiamento privado, o Fundo revisou as metas quantitativas do México, permitindo ao país continuar a sacar os recursos previstos no programa a despeito de não atingir as metas originalmente acordadas (Boughton, 2001, pp. 448-450).

Em outubro de 1987, a "Segunda-feira Negra" da Bolsa de Nova York teve um efeito devastador sobre o mercado mexicano de capitais. Nas seis semanas seguintes, as ações listadas na Bolsa do México perderam $75 \%$ do valor. Em novembro, a moeda mexicana perdeu um terço do seu valor com relação ao dólar no mercado paralelo (Boughton, 2001, pp. 
450-451). As dificuldades econômicas colocavam em risco o programa com o FMI, o que impediria o país de obter as últimas parcelas do financiamento com o Fundo.

Para enfrentar a crise, o governo mexicano anunciou, em dezembro, o Pacto de Solidariedade Econômica. Dentre as medidas do "Pacto", constaram a desvalorização imediata do peso em $18 \%$ no câmbio oficial, o aumento do superávit fiscal primário em 3\% do PIB, a liberalização do comércio por meio de cortes de tarifas e eliminação de barreiras não-tarifárias, e um controle de salários. O FMI apoiou todas as medidas e, em março de 1988, o Conselho Executivo da instituição aprovou a liberação das últimas parcelas do programa de 1986. Desta forma, a dívida do país com o fundo atingiu quase DES 4 bilhões, o equivalente a $335 \%$ da sua quota (Boughton, 2001, pp. 451-453).

Ainda em dezembro, o México tentaria reduzir parte de sua dívida por meio de uma iniciativa inovadora, empreendida no âmbito do menu approach do Plano Baker. Enquanto avançavam as conversas com o FMI que levariam à adoção do Pacto, o governo mexicano negociava diretamente com o governo dos EUA e com o banco Morgan Guaranty a montagem de uma proposta de troca da dívida por bônus garantidos por papéis do Tesouro norte-americano.

Em 29 de dezembro, o México anunciou sua proposta. O país pretendia trocar até US\$ 20 bilhões de sua dívida por novos bônus emitidos pelo governo mexicano, chamados bônus 2008, com maturidade de 20 anos e garantidos pelo Tesouro. A troca seria feita com desconto, por meio de leilão, e embora não fosse estipulada uma porcentagem mínima, as autoridades mexicanas declaravam esperar que o desconto chegasse a $50 \%$ do valor de face. Finalmente, o governo concedeu aos bancos pouco menos de dois meses para responder à proposta e fazer suas ofertas (Boughton, 2001, p. 490).

A reação do mercado misturou ceticismo e hostilidade. Do lado do ceticismo, o desconto esperado pelo governo mexicano foi considerado alto demais, pois a dívida do país já era negociada no mercado secundário por cerca de $50 \%$ do valor de face. A hostilidade ficou por conta de alguns bancos do comitê consultivo, em particular o Citibank, porque a oferta fora negociada fora do comitê (Parola, 1991, pp. 145-146, Boughton, 2001, p. 491).

Os resultados da oferta mexicana, anunciados em 3 de março, foram decepcionantes. Dos mais de 500 bancos credores, apenas 139 apresentaram propostas que, somadas, representariam a troca de US\$ 6,7 bilhões da dívida por novos bônus. As propostas aceitas pelo governo mexicano totalizaram apenas US\$ 3,67 bilhões, montante trocado por US\$2,56 
bilhões em bônus 2008 — representando um desconto de apenas 30\% (Parola, 1991, p. 146, Boughton, 2001, p. 490-491).

O apoio do Tesouro dos EUA à oferta mexicana abriu o caminho, do ponto de vista político, para a adoção de mecanismos de alívio da dívida. Por outro lado, os modestos resultados da oferta também deixaram claro que a viabilidade de tais fórmulas dependia de garantias explícitas por parte dos países desenvolvidos. Ademais, o caráter voluntário da oferta mexicana reduziu o montante de desconto que foi apropriado pelo país devedor, pois incentivava os bancos a adotar uma estratégia de "esperar para ver": como a redução da dívida de um país aumenta sua capacidade global de pagar a dívida restante, a melhor estratégia para um banco individualmente é oferecer a menor redução de dívida possível, na expectativa de que outros bancos que precisem liquidar suas posições mais rapidamente ofereçam descontos maiores e, assim, aumentem o valor de mercado da dívida remanescente ${ }^{90}$. Por fim, a oposição do Citibank e de outros membros do comitê consultivo mostrou as dificuldades que os países devedores enfrentariam ao tentar propor, isoladamente, uma estratégia de redução de dívida. Para ter êxito, tais estratégias deveriam ter caráter global e contar com o apoio direto dos governos dos países industrializados, particularmente dos Estados Unidos.

\subsection{O PLANO BRADY}

Em 1988, a continuada atuação do FMI e do Tesouro dos EUA, sob os princípios da Estratégia dos Cinco Pontos e o guarda-chuva retórico do Plano Baker, tinha logrado reduzir o risco dos money center banks com a dívida dos países em desenvolvimento. Em 1982, a exposição dos nove maiores bancos norte-americanos aos países em desenvolvimento correspondia a $255 \%$ de seu capital; em 1988, esta proporção tinha caído para 104\% (Cline, 1995, pp. 74-75). O risco sistêmico representado pelo endividamento do Terceiro Mundo tinha sido consideravelmente reduzido.

Esta redução do risco sistêmico foi obtida à custa do aumento da exposição dos próprios países credores e das instituições multilaterais, bem como da geração de superávits comerciais por parte dos países em desenvolvimento que prejudicaram os setores industriais e agrícolas dos EUA. Como resultado, embora seja possível afirmar que o Plano Baker tenha logrado evitar uma crise do sistema bancário norte-americano, politicamente a estratégia tornava-se progressivamente menos sustentável. Como já vimos, em 1988 o ativismo do

\footnotetext{
${ }^{90}$ Para uma discussão desse problema, cf. Bulow e Rogoff (1991).
} 
Congresso ameaçava retirar do Executivo norte-americano o controle sobre a gestão da crise da dívida.

Desta forma, o governo norte-americano viu-se obrigado a alterar sua estratégia para a gestão da crise da dívida, sob risco de vê-la ser desmontada e reconfigurada pelo Congresso. A partir de 1988, a escolha, para o governo, não era mais manter ou modificar a estratégia vigente; era entre ou alterar a estratégia o suficiente para manter a iniciativa política, ou demorar demais e vê-la ser modificada de acordo com as preferências do Congresso, manifestamente mais favorável a aumentar os mercados de exportação para os produtos industriais e agrícolas dos EUA do que em garantir a lucratividade dos grandes bancos.

A inviabilidade de manter o Plano Baker como estratégia para a dívida estava clara para o próprio governo pelo menos desde 1988. Como admitiu o próprio David Mulford perante uma audiência no Senado em 1990,

Em 1988, depois de três anos de experiência com o Plano Baker, os fatos e números começaram a chegar. Havia alguns padrões que eram claramente perturbadores.

Um deles era que os bancos comerciais estavam claramente em um processo de retirada. [...] Eles reconheciam no geral que seus empréstimos não seriam pagos integralmente, e não queriam colocar novos recursos adicionais. [...]

Segundo, ficou claro que, à medida que os bancos se retiravam, a exposição das instituições internacionais, e a dos países-membros por meio dessas instituições, estava aumentando de forma muito aguda. Estava implícita, neste processo, uma transferência de risco para as instituições oficiais [que], se não fosse detida, claramente iria por fim resultar em que praticamente todo o estoque da dívida seria gradualmente transferido para o lado oficial. Isso era algo que sentíamos que era inaceitável.

Terceiro, estava claro em 1988, e eu não creio que estivesse claro antes disso, que havia uma diferenciação na comunidade bancária e uma atenção aos mercados que tornava possível pensar em soluções de mercado para alguns desses problemas. [...] Em outras palavras, [...] talvez a redução da dívida, se fosse realizada em bases voluntárias, pudesse coexistir com a provisão continuada de alguma forma de dinheiro novo ${ }^{\text {lix }}$. (U.S. Senate, 1990b.)

A mudança na estratégia do governo norte-americano teve início nos primeiros meses de 1988. Ao apoiar a oferta mexicana de dezembro de 1987, o Tesouro mostrava que não rejeitava mais toda e qualquer forma de alívio da dívida. Ao contrário, David Mulford acreditava que tais esquemas se tornariam cada vez mais importantes. Nesse sentido, no começo de 1988 Mulford propôs a Baker que o governo norte-americano alterasse sua política para a dívida de forma a aumentar o uso de mecanismos de redução da dívida com garantias oficiais. Baker, no entanto, vetou qualquer movimento neste sentido, por considerá-lo impraticável em um ano eleitoral, pois naquele momento ele abriria um precedente para que 
agricultores, indústrias, municipalidades, escolas e outros devedores domésticos norteamericanos exigissem o mesmo (Cline, 1995, p. 217).

De qualquer forma, a mudança pedida por Mulford não era radical. Sua abordagem dava mais peso a esquemas de alívio da dívida, desde que fossem estritamente voluntários ou seja, que não incluíssem nenhuma forma de coerção para os bancos credores. Esta posição era, naturalmente, compartilhada pelos bancos, aos quais não seria interessante verem-se obrigados a participar de operações de redução da dívida, o que reduziria seu poder de barganha vis-à-vis os países devedores.

Em agosto de 1988, James Baker deixou o cargo de secretário do Tesouro para coordenar a campanha à presidência de George Bush e foi sucedido pelo amigo Nicholas Brady. Além das relações pessoais com o alto escalão do governo Reagan, por quem fora indicado em 1982 para ocupar o assento no Senado deixado vago pela renúncia de Harrison Williams (democrata de Nova Jersey) e no qual participara de diversos comitês de assessoria, Brady tivera uma carreira de muito sucesso no setor financeiro e, ao ser indicado secretário do Tesouro, era presidente do conselho de administração do banco de investimentos Dillon Read.

A troca de comando do departamento do Tesouro não significou uma ruptura; ao contrário, a gestão Brady pode ser considerada uma continuidade da gestão Baker. Isto se aplica inclusive no que tange à gestão da crise da dívida, do que é prova o fato de que David Mulford - que, secretário-assistente para Assuntos Internacionais, era o principal formulador desta política durante os anos Baker - continuou a ser a figura-chave do Tesouro para o tema de dívida externa e foi promovido a subsecretário de Assuntos Internacionais ${ }^{91}$. A vitória de George Bush nas eleições presidenciais de 1988 garantiu a permanência do mesmo grupo no comando do Tesouro por mais quatro anos.

Uma vez obtida a vitória de Bush, o Departamento do Tesouro mobilizou-se rapidamente para impedir que o ativismo congressual lhe tirasse a iniciativa sobre o problema da dívida. Para isso, era necessário impedir a criação da Autoridade para o Gerenciamento da Dívida Internacional (IDMA), proposta pelo Congresso.

Como já visto anteriormente, a PL 100-418, sancionada no final de agosto de 1988, obrigava o Tesouro a estudar a pertinência e a viabilidade da criação de autoridade para gerir a dívida externa do Terceiro Mundo. De acordo com a legislação aprovada, o Secretário do Tesouro teria seis meses, a partir da data da entrada em vigor da lei, para apresentar seu

\footnotetext{
${ }^{91}$ Sobre o papel de David Mulford na política para a dívida, cf. Farias (2007), p. 109, nota 101.
} 
primeiro relatório, e mais seis meses para apresentar o segundo. O Secretário do Tesouro deveria iniciar discussões com outros países para a criação da IDMA, a não ser que considerasse que tais tratativas causariam redução do valor de mercado da dívida ou aumento da probabilidade de default desta dívida ou do seu serviço. Neste caso, ele deveria explicar, em seu primeiro relatório, as razões que o levaram a tais conclusões.

O relatório sobre a IDMA deveria ter sido apresentado em 23 de fevereiro, mas o governo não cumpriu o prazo. Antes de apresentar seu relatório ao Congresso, o Tesouro apresentou algo mais ambicioso, que dominaria totalmente a agenda e eclipsaria a idéia de criar a IDMA: uma nova política para a dívida dos países em desenvolvimento (Farias, 2007, p. 108).

A nova política foi apresentada por Nicholas Brady em 10 de março, em uma conferência sobre a dívida do Terceiro Mundo organizada pela Brookings Institution e pelo Bretton Woods Committee (Brady, 1989). O Plano Brady, como ficaria conhecido, continha em linhas gerais os seguintes elementos ${ }^{92}$ :

a) credores e devedores negociariam acordos de redução de dívida, nos quais a dívida "velha" seria substituída por dívida "nova", com desconto no principal ou nos juros, garantidas por títulos públicos dos países industrializados ou do Banco Mundial. Estes títulos seriam adquiridos pelos países devedores, se necessário com financiamento das instituições financeiras multilaterais. Dentre os diversos mecanismos de redução de dívida, seria encorajada a adoção de programas de debtequity swap, totalmente voluntários, por parte dos países devedores, como forma de reduzir suas dívidas comerciais. Estas operações trocavam dívidas com bancos comerciais, denominadas em dólares, por títulos denominados em moeda local que podiam ser utilizados para a aquisição de ativos locais, tais como empresas estatais privatizadas;

b) para facilitar a execução de operações de redução da dívida externa, os bancos concederiam um waiver, por três anos, das cláusulas de partilha (sharing clause) e fiança negativa (negative pledge clause) que compunham os acordos de empréstimo. A cláusula de partilha determina que qualquer pagamento feito aos bancos deve ser proporcionalmente rateado entre eles, enquanto a cláusula de fiança estabelece igualdade entre os credores, proibindo que o devedor discrimine entre seus credores

\footnotetext{
${ }^{92}$ Cf. Brady (1989), Devlin (1990) e Parola (1991).
} 
concedendo preferências de pagamento entre eles (Parola, 1991, pp. 138-139). Estas cláusulas restritivas mantinham a coesão dos credores ao preço de enrijecer as negociações, pois conferiam, a todos os bancos credores de um país, o poder de impedir que operações de redução de dívida fossem levadas a cabo. Na prática, o waiver destas cláusulas eliminaria o poder de veto dos bancos pequenos sobre operações de redução de dívida, permitindo que os bancos que quisessem reduzir sua exposição o fizessem sem ter de convencer os outros a participar ou, no mínimo, aceitar a operação. O prazo de três anos era determinado para incentivar os participantes a chegarem rapidamente a um acordo;

c) o FMI e o Banco Mundial passariam a oferecer financiamento para o pagamento de juros e aquisição de garantias para devedores engajados em operações de desconto do montante da dívida ou de redução dos juros pagos, ou para recomposição de reservas de países devedores depois de operações de recompra de dívida;

d) as instituições financeiras multilaterais promoveriam, por meio de financiamentos, reformas econômicas nos países devedores que reduzissem o tamanho do Estado, revertessem a "fuga de capitais" que, segundo as autoridades norte-americanas, era um dos grandes responsáveis pela crise ${ }^{93}$, e proporcionassem um aumento da taxa de crescimento econômico;

e) ao mesmo tempo, o FMI e o Banco Mundial deixariam de exigir que um país devedor obtivesse comprometimento de "dinheiro novo" por parte do comitê dos bancos como condição para desembolsar recursos previstos em seus programas (delinking);

f) para garantir ampla disponibilidade de recursos, o governo dos Estados Unidos iniciaria negociações com os outros países-membros do FMI com vistas a acordar um aumento geral de quotas do Fundo até o final de 1989.

O apoio expresso no Plano Baker a mecanismos que buscassem redução de dívidas foi vista, em um primeiro momento, como uma inflexão da política do governo norte-americano para a dívida externa, que teria passado a levar em conta a visão dos países da América Latina de que a dívida era o principal obstáculo ao desenvolvimento (Parola, 1991, p. 157). "A dívida externa já era", comemorou a revista Veja na capa de sua edição de 15 de março. "Caiu

\footnotetext{
${ }^{93}$ Em seu discurso, Nicholas Brady afirmou que "o total de capital que fugiu da maioria dos países devedores é comparável à sua dívida” (Brady, 1989). Mulford repetiria essa idéia diversas vezes, em audiências perante o Congresso.
} 
um tabu", afirmou o ministro da Fazenda do Brasil, Mailson da Nóbrega (Veja, 1989, pp. 8283). No entanto, uma análise mais detida indica que o Plano Brady era de fato uma evolução da abordagem vigente até então, de maneira a permitir que os países devedores restaurassem sua capacidade de pagamento e normalizassem suas relações com os grandes bancos, voltando assim ao mercado internacional de crédito. Nesse sentido, a novidade do Plano Brady era o fato de que a ênfase em proteger os ativos dos bancos era substituída pela ênfase em trazer de volta os países devedores ao mercado financeiro (Lehman, 1994).

Esta mudança de ênfase só foi possível porque o sistema financeiro norte-americano não estava mais ameaçado de colapso por um default dos grandes devedores. Os mais de seis anos de gestão da crise da dívida com foco na proteção dos ativos dos bancos tinham logrado permitir-lhes reduzir suas exposições a níveis seguros.

O ponto-chave do Plano Brady era a oferta explícita de recursos públicos para incentivar os bancos a participarem dos esquemas de redução das dívidas, assumindo perdas no valor de mercado dos seus empréstimos em troca de garantias fortes sobre os créditos remanescentes. Dos países devedores, por outro lado, o Plano exigia a realização de novas rodadas de reformas econômicas liberalizantes. Os objetivos e linhas gerais da iniciativa de Brady eram muito semelhantes aos da Autoridade de Gerenciamento da Dívida Internacional (IDMA) defendida pelo Congresso. Por que, então, o Tesouro lutou tanto contra a IDMA? Por que preferiu confrontar a proposta do Legislativo e adotar sua própria abordagem?

A principal motivação do Tesouro em propor uma mudança na estratégia sem criar uma nova agência parece ser manter para si o controle sobre o processo. Note-se que propostas de redução da dívida muito semelhantes ao Plano Brady, apresentadas pelo presidente da França, François Mitterand, e pelo ministro das Finanças do Japão, Kiichi Miyazawa, foram também rejeitadas liminarmente pelo governo norte-americano (Cline, 1995, p. 227). No Plano Brady, o Fundo continuava a ocupar o papel central na gestão da dívida. Os objetivos amplos de reduzir o endividamento e restaurar o crescimento e acesso dos países em desenvolvimento ao mercado financeiro internacional eram compartilhados por todos; no entanto, para se atingir estes objetivos haveria custos que deveriam ser divididos por diversos agentes, criando vencedores e perdedores. A divisão desses custos seria feita nos processos de negociação; portanto, quem estivesse na condução de tais negociações é que determinaria quem seriam os vencedores e quem seriam os perdedores. Ao manter o FMI como gestor da crise da dívida, o Tesouro garantia que continuaria a conduzir, mesmo que 
indiretamente, as negociações. Desta forma, o Tesouro manteria para si o poder de determinar a divisão de custos - e, portanto, de definir quem sairia ganhando e quem sairia perdendo.

Note-se que o simples lançamento do Plano representou uma vitória pessoal para Nicholas Brady. Outros grupos dentro do governo norte-americano - em particular o Federal Reserve - se opunham à possibilidade de oferecer qualquer tipo de redução de dívida aos países em desenvolvimento. Os termos algo vagos nos quais o Plano Brady foi lançado e a ausência de detalhes sobre seus mecanismos refletiram o fato de que a iniciativa foi o resultado de um compromisso entre diversos atores do governo (Mossberg e Truell, 1989). Para dissipar os boatos que circularam na imprensa nos dias seguintes quanto a uma possível oposição do próprio presidente Bush ao Plano, a Casa Branca emitiu uma estranha declaração, em 14 de março, na qual afirmava o óbvio: “o presidente apóia totalmente os conceitos e processos para redução da dívida e crescimento econômico delineados no discurso de Brady na última sexta". A declaração tinha efeito interno, indicando para os recalcitrantes dentro do próprio governo e do Federal Reserve Board que era intenção da Casa Branca executar o plano do Tesouro (Seib e Mossberg, 1989).

Nos meses seguintes, o detalhamento dos mecanismos do Plano Baker indicaria que a prioridade do Tesouro era obter algum alívio da dívida para os países em desenvolvimento e ao mesmo tempo minimizar as perdas dos grandes bancos (Parola, 1991). O waiver das cláusulas restritivas aumentava o poder das grandes instituições financeiras vis-à-vis os bancos regionais, eliminando a prerrogativa que estes tinham de emperrar as negociações e permitindo que os money center banks chegassem a vantajosos acordos separados com os países devedores. A opção de aceitar descontos da dívida oferecia aos bancos regionais uma saída dos empréstimos, o que até então não era possível. A queda no financiamento privado seria compensada pelos novos financiamentos públicos, fornecidos pelo FMI e pelo Banco Mundial.

Ademais, o foco do Plano Brady em operações de debt-equity swap indicava um viés em favor das preferências dos grandes bancos. Nestas operações, um país devedor compra sua dívida de um banco credor a preço entre o valor de face e o valor de mercado, e o dinheiro recebido pelo banco credor deve ser investido na economia do país devedor. Como mostra Parola, estas operações eram mais interessantes aos grandes bancos do que aos pequenos, e não representavam grande vantagem aos devedores. Em primeiro lugar, os money center banks tinham mais estrutura do que os bancos regionais para realizar investimentos diretos em 
países em desenvolvimento ou para encontrar tomadores finais que tivessem interesse em fazer tais investimentos. Em segundo lugar, as operações de debt-equity swap não eram interessantes para os países devedores porque causavam inflação e representavam um pagamento antecipado de dívida (Parola, 1991, pp. 148-149). Como afirmou Jeffrey Sachs, em audiência perante a Comissão de Bancos, Finanças e Assuntos Urbanos da Câmara:

O problema com um debt-equity swap é que ele é altamente inflacionário, exatamente nas circunstâncias nas quais o governo está desesperadamente tentando controlar a inflação. No curto prazo, a carga fiscal do debt-equity swap é várias vezes maior do que a carga dos pagamentos de juros sobre a dívida, em um momento no qual os pagamentos de juros já são incontrolavelmente altos.

Considere como ilustração o Brasil, cujo programa de troca de dívida por ativos foi um grande responsável pela hiperinflação que agora está desestabilizando a economia e a sociedade. Suponha que US\$ 1 bilhão de dívida seja convertido em um debt-equity swap. Sem a conversão, o US\$ 1 bilhão de dívida teria um impacto sobre o fluxo de caixa do governo brasileiro de cerca de US\$ 100 milhões [considerando uma taxa de juros anual de $10 \%$, já que o vencimento foi reescalonado para 20 anos]. Alternativamente, suponha que o governo recompre a dívida em uma troca usando cruzados. O preço da dívida no mercado secundário seria de cerca de US\$ 400 milhões, ou seja, teria um desconto de US\$ 600 milhões com relação ao valor de face. Em um debt-equity swap típico, o Brasil poderia capturar cerca de metade do desconto, em outros termos pagar US\$ 700 milhões em cruzados por US\$ 1 bilhão de valor de face da dívida. Portanto, o impacto sobre o caixa aumentou de US\$ 100 milhões para US\$ 700 milhões!

Para evitar as consequiências inflacionárias de um aumento de US\$ 700 milhões da oferta monetária, o governo brasileiro poderia vender títulos do governo (chamadas OTNs) para enxugar os US\$ 700 milhões em cruzados emitidos. Neste caso, a dívida interna subiria em cerca de US\$ 700 milhões. Como a taxa de juros real das OTNs é de cerca de $20 \%$ ao ano, os pagamentos de juros das OTNs somariam cerca de US\$ 140 milhões por ano. Portanto, enquanto a dívida externa do Brasil é reduzida, o custo total do serviço da dívida, na verdade, aumenta $^{\mathrm{lx}}$. (U.S. House, 1989a, pp. 369-370.)

A despeito da retórica quanto à necessidade de impedir que continuasse a haver a "transferência de risco" dos bancos privados para o setor público (Brady, 1989), na prática o Plano Brady instituía novas formas pelas quais os governos dos países industrializados financiavam os países devedores para que os bancos credores continuassem a reduzir sua exposição. A principal diferença, agora, era que os bancos sofreriam algumas perdas, pelo menos em termos de redução do valor nominal de seus créditos. Mas o influxo de recursos públicos não apenas continuaria, mas aumentaria. Além dos recursos já disponíveis ao FMI e ao Banco Mundial - cujo capital, como se recorda, tinha no ano anterior sido ampliado em US\$ 75 bilhões - Brady deu início a negociações para a ampliação do capital do Fundo. Esta ampliação, assim como o delinking dos desembolsos do FMI com os dos bancos (o que facilitava a concessão de empréstimos) indicava uma disposição do governo norte-americano 
de usar a instituição como principal meio para aportar grandes volumes de recursos públicos na gestão do problema da dívida.

\subsubsection{A reação ao Plano Brady no Congresso}

Apresentado em reação ao ativismo congressual que ameaçava tirar do Tesouro o controle sobre a gestão da crise da dívida, o Plano Brady tornou-se imediatamente o principal item da agenda do Congresso norte-americano para o tema, eclipsando totalmente a idéia de criação de uma Autoridade de Gerenciamento da Dívida Internacional (IDMA). Como comentou um banqueiro regional, "o objetivo do Plano Brady era calar Schumer e Bradley. E funcionou como um encanto" "lxi (Madrid, 1992, p. 100).

Como mostra a Tabela 7.2, os meses que se seguiram ao anúncio do Plano Brady assistiram a intensa atividade congressual sobre a nova iniciativa. No entanto, esta atividade limitou-se a debates e audiências; ao contrário do que ocorrera na legislatura anterior, o interesse do Congresso não se refletiu em novas propostas de legislação.

Em 16 de março, apenas seis dias depois do discurso de Brady na Brookings Institution, David Mulford depôs perante a Subcomissão de Desenvolvimento, Finanças, Comércio e Política Monetária da Câmara de Representantes para apresentar os resultados dos estudos realizados pelo Tesouro sobre a viabilidade da IDMA, de acordo com as exigências da P.L. 100-418.

Como seria de se esperar, no estudo sobre a IDMA o Tesouro sustentou que as propostas de criar uma autoridade para gerir a dívida externa "transferem o risco dos empréstimos aos países em desenvolvimento dos bancos comerciais para as instituições financeiras internacionais ou para os governos credores" (Department of the Treasury, 1989, p. 4). Depois de criticar a IDMA, o texto elogiava a proposta que acabara de ser apresentada por Nicholas Brady, afirmando que ela iria "catalizar novas oportunidades para transações voluntárias e baseadas no mercado", "melhor aproveitar o potencial das fontes alternativas de capital privado", "minimizar o custo de transferência de risco para os países credores", "evitar preços obrigatórios para troca da dívida" e "manter uma abordagem orientada ao mercado nas reestruturações de dívida" (ibidem, pp. 6-7). O relatório chegava a afirmar que as próprias pressões do Congresso em prol do estabelecimento da IDMA causaram redução do valor de mercado das dívidas dos países em desenvolvimento, pois teriam criado, entre os credores, temor de que seriam obrigados a assumir prejuízos causados por programas de redução da 
dívida e, entre os devedores, resistência à adoção de programas de debt-equity swap porque haveria a expectativa de que, quando a IDMA estivesse funcionando, obteriam condições melhores (ibidem, p. 18).

Tabela 7.2

Audiências realizadas entre março e dezembro de 1989 no Congresso sobre a crise da dívida

\begin{tabular}{|c|c|c|c|}
\hline Data & Casa & Comissão & Tema \\
\hline $\begin{array}{l}8 \text { de } \\
\text { fevereiro e } \\
16 \text { de março }\end{array}$ & Senado & $\begin{array}{l}\text { Subcomissão de Finanças Internacionais e Política } \\
\text { Monetária da Comissão de Bancos, Habitação e } \\
\text { Assuntos Urbanos }\end{array}$ & $\begin{array}{l}\text { Novas abordagens } \\
\text { para o problema da } \\
\text { dívida do Terceiro } \\
\text { Mundo }\end{array}$ \\
\hline 5 de abril & Câmara & $\begin{array}{l}\text { Subcomissão de Desenvolvimento Internacional, } \\
\text { Finanças, Comércio e Política Monetária da } \\
\text { Comissão de Bancos, Finanças e Assuntos Urbanos }\end{array}$ & $\begin{array}{l}\text { Dívida do Terceiro } \\
\text { Mundo: reação } \\
\text { pública do Plano } \\
\text { Brady }\end{array}$ \\
\hline 19 de abril & Câmara & $\begin{array}{l}\text { Subcomissão de Política Econômica Internacional } \\
\text { e Comércio da Comissão de Assuntos Estrangeiros }\end{array}$ & $\begin{array}{l}\text { Crise internacional da } \\
\text { dívida: uma revisão do } \\
\text { Plano Brady }\end{array}$ \\
\hline 11 de maio & Câmara & Comissão de Agricultura & $\begin{array}{l}\text { Dívida do Terceiro } \\
\text { Mundo e seu impacto } \\
\text { sobre o setor agrícola } \\
\text { dos EUA }\end{array}$ \\
\hline 18 de maio & Ambas & $\begin{array}{l}\text { Comissão Econômica Conjunta do Congresso dos } \\
\text { EUA }\end{array}$ & $\begin{array}{l}\text { Efeitos da crise da } \\
\text { dívida do Terceiro } \\
\text { Mundo sobre a } \\
\text { agricultura dos EUA }\end{array}$ \\
\hline 24 de maio & Câmara & $\begin{array}{l}\text { Subcomissão de Desenvolvimento Internacional, } \\
\text { Finanças, Comércio e Política Monetária da } \\
\text { Comissão de Bancos, Finanças e Assuntos Urbanos }\end{array}$ & $\begin{array}{l}\text { Enhanced Structural } \\
\text { Adjustment Facility do } \\
\text { FMI e Sétima Revisão } \\
\text { do Capital do IDM }\end{array}$ \\
\hline 30 de maio & Câmara & $\begin{array}{l}\text { Subcomissão de Política Econômica Internacional } \\
\text { e Comércio da Comissão de Assuntos Estrangeiros }\end{array}$ & $\begin{array}{l}\text { Crise internacional da } \\
\text { dívida }\end{array}$ \\
\hline 27 de junho & Câmara & $\begin{array}{l}\text { Subcomissão de Desenvolvimento Internacional, } \\
\text { Finanças, Comércio e Política Monetária da } \\
\text { Comissão de Bancos, Finanças e Assuntos Urbanos }\end{array}$ & $\begin{array}{l}\text { Influência das práticas } \\
\text { contábeis e } \\
\text { regulatórias no } \\
\text { problema da dívida do } \\
\text { Terceiro Mundo }\end{array}$ \\
\hline $\begin{array}{l}18 \text { de } \\
\text { outubro }\end{array}$ & Senado & $\begin{array}{l}\text { Comissão de Bancos, Habitação e Assuntos } \\
\text { Urbanos }\end{array}$ & $\begin{array}{l}\text { Impacto da dívida do } \\
\text { Terceiro Mundo sobre } \\
\text { o comércio dos EUA }\end{array}$ \\
\hline
\end{tabular}


De qualquer forma, as conclusões dos estudos tiveram pouquíssimo espaço nos debates de 16 de março, dominados que foram pela nova estratégia para a dívida que tinha sido proposta pelo governo.

Na abertura da audiência, Charles Schumer saudou a proposta do Tesouro como uma grande "janela de oportunidade" para se buscar uma solução para a crise. Referindo-se à IDMA, relembrou que "uma agência é um instrumento apoiado por muitos deste lado". No entanto, afirmou que "eu não estou preso a uma agência" e que "não creio que tenhamos que

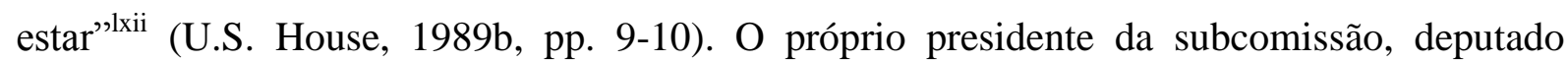
William Fauntroy, admitiu que o Plano Baker sepultava a idéia da IDMA:

Estou essencialmente satisfeito em notar que o governo decidiu enfatizar a redução da dívida em vez da cobrança da dívida, um fato que ajuda a temperar minha decepção, falando francamente, com a escolha do Tesouro de rejeitar a autoridade de gerenciamento da dívida que o Congresso tinha proposto.

Se uma proposta alternativa pode alcançar os resultados desejados, eu penso que, como o Sr. Schumer indicou, é claro que nós não estamos presos a nenhum mecanismo em particular ${ }^{\text {liii }}$. (U.S. House, 1989b, p. 14, grifos meus.)

Nas audiências seguintes, os debates se concentrariam em três problemas: primeiro, o fato de que o discurso de Nicholas Brady tinha apresentado linhas gerais de ação, mas que faltava especificar e quantificar as medidas a serem tomadas; segundo, se seria possível obter alívio suficiente das dívidas por meio de um mecanismo voluntário; terceiro, a percepção de que o Plano seria apenas mais uma forma de utilizar recursos públicos para ajudar os bancos a se livrarem do problema da dívida.

O depoimento de Jeffrey Sachs perante a subcomissão de Política Econômica Internacional e Comércio da Câmara, em 19 de abril, exemplifica a preocupação com os dois primeiros problemas. Segundo Sachs, “o testemunho dessa manhã e toda a confusão generalizada sobre o tema deixam claro que os detalhes ainda não foram acertados, e eu vou tentar sublinhar algumas das áreas sobre as quais eu acho que é preciso pensar mais" "lxiv (U.S. House, 1989d, p. 29). Com relação ao caráter voluntário das operações redução de dívida, Sachs mostrou-se cético:

As forças de mercado não funcionam numa situação na qual é do interesse individual de cada credor deixar que todos os outros credores façam o que quiserem, mas que seja do seu interesse particular manter a dívida. Nós temos o tipo clássico de problema da carona, o qual esmaga qualquer redução significativamente grande da dívida. E eu estive com executivos do Citibank que me disseram, seis meses atrás, que "bem, somos todos a favor da redução da dívida. Nós não vamos concedê-la. Nós temos certeza de que outros bancos vão conceder"llxv. (ibidem, p. 31). 
O depoimento de Shafiqul Islam perante a subcomissão de Desenvolvimento Internacional, Finanças, Comércio e Política Monetária da Câmara de Representantes, em 5 de abril, apresentou uma excelente discussão do terceiro problema. Segundo Islam,

No mínimo, um plano que requer US\$ 25 bilhões de recursos multilaterais para apoiar US\$ 70 bilhões em redução da dívida parece representar uma forma extremamente cara de comprar alívio de dívida dos bancos, mesmo que a intenção declarada seja proteger os contribuintes dos países credores. [...]

Se as instituições de Bretton Woods não limitarem o uso de seus recursos como garantias de pagamentos de juros somente para as dívidas daqueles países cujas obrigações junto aos bancos tenham sido reduzidas para um nível que permita que o serviço do restante da dívida possa ser pago totalmente, estas instituições internacionais se tornarão o mecanismo indireto de um salvamento dos bancos por parte do contribuinte ${ }^{\mathrm{lxvi}}$. (U.S. House, 1989c, pp. $81,83)$.

Na audiência do dia 19 de abril, o secretário-assistente para Assuntos Internacionais do Departamento do Tesouro, Charles Dallara, seria obrigado a tratar diretamente deste problema, em resposta à pergunta do deputado Toby Roth (republicano de Wisconsin):

Estou vindo de um programa de rádio da C-Span no qual recebemos ligações do público, e as questões sobre o Plano Brady foram muito hostis. Várias vezes me perguntaram "por que o contribuinte americano deveria carregar o peso das obrigações da dívida do Terceiro Mundo?". Eu acho que essa é uma pergunta muito boa. Eu pensei que talvez o senhor pudesse tentar respondê-la ${ }^{\text {lxvii }}$. (U.S. House, 1989d, p. 20.)

A resposta de Dallara foi uma defesa do compromisso dos Estados Unidos com as instituições financeiras multilaterais como um elemento tradicional da política externa norteamericana, evitando a questão, muito mais espinhosa, relativa a quais seriam os principais beneficiários e quem arcaria com os custos do Plano Brady:

Os contribuintes americanos têm sido convocados a apoiar essas organizações internacionais há 40 anos. Isto ocorre porque tal apoio - e eu acho que isso é um consenso bipartidário há mais de quatro décadas — atende aos interesses dos Estados Unidos, e atende aos nossos interesses estratégicos e de segurança. [...] Mas além disso é importante reconhecer os benefícios econômicos, tanto diretos quanto indiretos, de nosso apoio às organizações multilaterais ${ }^{\text {lxviii }}$. (U.S. House, 1989d, pp. 20-21.)

Apesar das preocupações manifestadas pelos congressistas, a análise dos debates no Congresso mostra que o Plano Brady obteve grande êxito em recuperar a iniciativa política sobre a crise para o Tesouro. A IDMA praticamente desapareceu das discussões. No rol dos especialistas convidados a depor, os economistas liberais e os representantes dos setores agropecuário e industrial perderam espaço, enquanto os representantes do setor financeiro passaram a ser convidados com maior freqüência. As críticas à falta de detalhamento da proposta de Brady passavam a ser entremeadas com elogios ao fato de que, finalmente, o Tesouro reconhecia a necessidade de aliviar as dívidas dos países em desenvolvimento. Os 
congressistas democratas ligados aos setores produtivos passaram a adotar posição mais conciliatória com relação à abordagem do Tesouro para a dívida, e a oposição passou a limitar-se aos parlamentares conservadores que, por princípio, eram contrários a qualquer tipo de envolvimento do governo na questão.

\subsubsection{A APROVAÇÃo do Plano PELO FMI}

O Comitê Interino do FMI aprovou formalmente o Plano Brady em 3 de abril, recomendando que o Conselho Executivo o avaliasse "com urgência" (Boughton, 2001, p. 494). O Conselho se reuniu em 19 de maio, com a expectativa de aprovar o plano com facilidade. No entanto, os diretores executivos se dividiram: enquanto os europeus tentaram limitar as mudanças nos procedimentos e as dimensões dos novos instrumentos de financiamento, os Estados Unidos (apoiados por Camdessus e pelos representantes dos países em desenvolvimento) pressionaram para que todas as propostas formuladas pelo Tesouro fossem adotadas. Depois de quatro dias de reuniões difíceis, o Conselho Executivo aprovou, na manhã de 23 de maio, todas as medidas solicitadas pelo governo norte-americano, com pequenas alterações (Boughton, 2001, pp. 495-498). Assim, mais uma vez os Estados Unidos conseguiram impor seus interesses ao Fundo, mesmo enfrentando a oposição de outros países industrializados.

O FMI trabalhou rapidamente. Antes mesmo da aprovação do Conselho Executivo, a equipe técnica do Fundo começou a trabalhar em programas de reestruturação para Costa Rica, Filipinas e México. Na tarde do mesmo dia 23 de maio, o Conselho Executivo reuniu-se novamente e aprovou os programas para a Costa Rica e para as Filipinas. Apenas três dias depois, em 26 de maio, o Conselho Executivo reuniu-se novamente e aprovou um programa para o México de mais de US\$ 4,6 bilhões — um dos maiores pacotes até então aprovados pela organização (Boughton, 2001, p. 499, 510). Tal pacote seria fundamental para o sucesso do Plano Brady; como afirmou o Washington Post em editorial, "o México será o teste da nova abordagem dos Estados Unidos para a dívida da América Latina. Para a política norteamericana ser aplicada em qualquer lugar, ela terá de ser aplicada primeiro - e com sucesso — no México" (Washington Post, 1989). O fracasso em chegar a uma fórmula que reduzisse significativamente a carga do serviço da dívida mexicana inviabilizaria politicamente a estratégia do Tesouro, possivelmente levando o Congresso a intervir. 


\subsubsection{O PaCote do Plano Brady Para o México}

Carlos Salinas de Gortari assumiu a presidência do México em dezembro de 1988 e deu início a um novo programa de ajuste econômico, o Pacto de Estabilização e Crescimento Econômico. Salinas também anunciou, ao assumir, um ambicioso plano de liberalização, que incluiria a privatização de boa parte das empresas estatais. O novo governo concluiu que o principal obstáculo à retomada do crescimento econômico era o elevado volume de transferências de recursos para o exterior (Levy, 1993, p. 381). Por isso, em fevereiro antes, portanto, do anúncio do Plano Brady — o governo mexicano procurou o FMI com vistas a estabelecer um programa de redução da dívida do país. Quando Nicholas Brady fez seu discurso na Brookings Institution em março, as conversas entre o México e o Fundo já estavam em andamento. Com o apoio de Camdessus, as partes chegaram a um acordo em poucos dias, e uma Carta de Intenções foi assinada pelas autoridades mexicanas em 11 de abril (Boughton, 2001, pp. 511-512). Segundo os termos do acordo, o México teria acesso a US\$ 3,63 bilhões em três anos, por meio do Extended Fund Facility. Deste montante, "uma parte considerável [...] será destinada a operações para reduzir a dívida e seu serviço", conforme declarou o secretário das Finanças do México, Pedro Aspe (Branigin, 1989). Em oposição à prática adotada até então, o Fundo não esperaria o compromisso dos bancos para liberar os financiamentos; ao contrário, a idéia era usar o acordo com o Fundo para demonstrar que o México teria os recursos necessários para bancar as operações de redução de dívida que seriam apresentadas (Boughton, 2001, p. 513).

No dia 17 de maio, o México finalizou um acordo de empréstimo com o Banco Mundial no valor de US\$1,96 bilhões, parte do qual poderia ser usado em operações de redução da dívida do país (Fuerbringer, 1989). No dia 26, o acordo foi aprovado pelo Conselho Executivo do FMI, o qual concordou em conceder, além dos US\$ 3,63 bilhões acordados um mês antes (dos quais $30 \%$ poderiam ser usados para apoiar operações de redução da dívida), mais US\$ 589 milhões no âmbito do Compensatory and Contingency Financing Facility. Destes recursos, US\$ 861 milhões seriam emprestados imediatamente. Ademais, o Conselho Executivo decidiu autorizar um empréstimo de US\$ 468 bilhões, a serem usados em operações de redução da dívida depois que o México chegasse a um acordo com os bancos credores (Kilborn, 1989).

Estes grandes pacotes de empréstimo foram concedidos ao México a despeito das reservas manifestadas por representantes dos países europeus, particularmente Reino Unido, 
Alemanha e Holanda — os mesmos que tentaram restringir as alterações de procedimento solicitadas pelo Tesouro dos EUA para viabilizar o Plano Brady. O apoio do governo dos EUA foi essencial para a aprovação desses pacotes, que pavimentaram o caminho para as negociações do México com os bancos credores.

O governo mexicano anunciou sua disposição de negociar com os bancos em 30 de março (Unal, Kunt e Leung, 1993, p. 414). No decorrer das negociações, o México viu-se obrigado a abandonar a possibilidade de propor a recompra da dívida, pois tal operação geraria um impacto inicial bastante negativo no seu fluxo de caixa. Da mesma forma, o governo mexicano se recusou a aceitar qualquer forma de debt-equity swap, por causa de seus efeitos inflacionários. Isto causou um desentendimento entre as autoridades mexicanas e os bancos credores, que chegaram a exigir, sem sucesso, que o pacote incluísse tais operações (Wijnbergen, pp. 24-25, Aggarwal, 1996, p. 370).

Em 23 de julho de 1989, o governo do México e o comitê assessor dos bancos chegaram a um acordo em princípio. Em 15 de setembro, as partes fecharam um acordo sobre o pacote que seria oferecido aos credores. O novo pacote cobriria dívidas que já tinham sido reestruturadas anteriormente (em 1984 e 1987) e que somavam cerca de US\$ 48,9 bilhões. Segundo a proposta, os bancos credores teriam um menu de três alternativas, que poderiam ser escolhidas livremente: (a) trocar sua dívida por títulos garantidos pelo Tesouro dos EUA, com desconto de $35 \%$ do valor de face, (b) trocar sua dívida por títulos com o mesmo valor de face (ao par), mas com juros fixos de 6,25\% ao ano, garantidos por conta colateral criada pelo México e (c) conceder novos empréstimos (emprestando "dinheiro novo" ou reciclando juros vencidos), sem garantias, à taxa de $0,8125 \%$ sobre a LIBOR, com sete anos de carência e 15 de vencimento. Esta última opção foi incluída, a despeito do maior interesse das autoridades mexicanas em obter redução da dívida, para impedir que os bancos acusassem o país de estarem sendo coagidos a aceitar sofrer perdas (Cline, 1995, p. 222). De qualquer forma, a exemplo do que ocorrera nos reescalonamentos anteriores baseados em concerted lending, havia um componente não-voluntário nesta nova operação: os bancos foram impedidos de simplesmente manterem seus créditos originais, pois toda a dívida deveria ser trocada por pelo menos um dos três instrumentos oferecidos no menu de opções.

A participação do governo dos EUA e das instituições financeiras multilaterais foi extremamente importante. Segudo David Mulford, a pressão do Tesouro sobre os bancos foi 
decisiva para o êxito da renegociação mexicana ${ }^{94}$ (Cline, 1995, p. 221). As instituições multilaterais, por seu turno, forneceram boa parte dos fundos necessários para viabilizar as operações.

Os títulos oferecidos pelo México em troca da dívida "velha" (opções a e b do menu de opções) seriam garantidos por papéis do Tesouro norte-americano. Estes papéis teriam de ser adquiridos pelo governo mexicano. Para comprar papéis do Tesouro em volume suficiente para viabilizar a operação, o México levantou US\$ 7 bilhões, dos quais US\$ 1,26 bilhão foi emprestado pelo Banco Mundial, US\$ 600 milhões pelo FMI e US\$ 2,05 bilhões pelo governo japonês. Adicionalmente, US\$ 750 milhões de uma linha de crédito do Banco Mundial já comprometida com o México para outras operações foram direcionados para o esquema de redução da dívida, bem US\$ 1,09 bilhão do FMI. Por fim, o país lançou mão de US\$ 1,25 bilhão de suas próprias reservas (Claessens e Wijnbergen, 1993, p. 969). Note-se que as instituições financeiras multilaterais participaram com mais da metade dos recursos necessários para viabilizar a operação de redução da dívida, incluindo US\$ 1,86 bilhão em novas linhas de crédito desenhadas especificamente para apoiar tais operações (Wijnbergen, 1991, p. 26).

Os bancos credores tiveram até janeiro de 1990 para fazer suas escolhas. Do total da dívida, $46,7 \%$ foi convertida a títulos ao par (alternativa b), 38,2\% a títulos com desconto (alternativa a) e apenas $15,1 \%$ foram convertidos em novos empréstimos. Dentre os bancos que escolheram a opção de fazer novos empréstimos, destaca-se o Citibank, que escolheu essa opção e aumentou seus empréstimos ao México (Unal, Kunt e Leung, p. 424).

O acordo proporcionou uma redução bruta de cerca de US\$12,1 bilhões, o equivalente a $25 \%$ do montante renegociado (US\$ 48,9 bilhões) e 12,8\% da dívida total, estimada em cerca de US\$ 95 bilhões (Wijnbergen, 1991, pp. 30-31). A redução líquida (descontando-se as novas dívidas oficiais contraídas para a compra das garantias) foi de US\$ 8,32 bilhões cerca de $8,75 \%$ da dívida total. Mais importante do que redução do volume da dívida, os prazos de amortização foram dilatados e o serviço da dívida foi reduzido em cerca de US\$ 1 bilhão por ano (Levy, p. 381). Estes resultados contribuíram para reduzir a incerteza e restabelecer a confiança dos investidores privados na economia mexicana, o que se refletiu em grande influxo de capitais externos. Logo depois do anúncio do acordo, a taxa de juros

\footnotetext{
${ }^{94}$ William Rhodes, do Citibank, confirma a afirmação de Mulford ao dizer que "embora o Departamento do Tesouro tenha pressionado os bancos a participar do plano do México, a maioria deles já estava preparada para participar de qualquer jeito" (Apud Cline, 1995, p. 236, nota 33).
} 
caiu cerca de 20 pontos percentuais em poucos dias (Claenssens, Oks e Wijnbergen, 1993, p. 1), o investimento doméstico, que entre 1982 e 1988 crescera a uma taxa anual de cerca de 1\%, cresceu 11,2\% entre 1989 e 1991 (ibidem, p. 6) e as entradas de capital líquidas saltaram de US\$ 3 bilhões em 1989 para US\$ 12,2 bilhões nos primeiros sete meses de 1991 (Levy, 1993, p. 381).

Os resultados macroeconômicos do pacote mexicano no âmbito do Plano Baker, caracterizados por Claenssens, Oks e Wijnbergen como "um sucesso espetacular" (1993, p. 1), abriram o caminho para negociações similares com quase todos os países devedores. Nos cinco anos seguintes ao anúncio do Plano, 18 países em desenvolvimento fecharam acordos no âmbito do Plano Brady, renegociando dívidas que somavam US\$ 191 bilhões (Cline, 1995, p. 232).

Por fim, os bancos também se beneficiaram da negociação com o México. O valor da dívida mexicana no mercado secundário subiu 128\% entre o final de 1989 e o final de 1993 (Cline, 1995, p. 248). Como mostram Unal, Kunt e Leung (1993), tanto o anúncio do Plano Baker quanto o anúncio da disposição do governo do México em negociar um acordo de redução da dívida tiveram um impacto positivo nos preços das ações dos grandes bancos. As ações do Citibank, que escolheu conceder mais empréstimos e aumentar sua exposição ao México, foram as que mais subiram, indicando que o mercado de capitais entendeu que o banco norte-americano estaria entre os maiores beneficiários da redução da dívida. O mesmo não se deu, no entanto, com o valor das ações dos bancos regionais, indicando que o próprio mercado de capitais percebia o Plano Baker como uma iniciativa que beneficiaria principalmente os bancos multinacionais.

\subsection{O AUMENTO DO CAPITAL DO FMI}

Um dos elementos do Plano Brady, presente desde o discurso na Brookings Institution em março de 1989, era o aumento do capital do Fundo — "até o fim do ano", segundo o secretário do Tesouro - de maneira a garantir que instituição tivesse os recursos necessários para implementar a nova estratégia. Como vimos, o governo dos EUA tinha se oposto ao aumento em 1988, quando estava prevista a nona revisão do capital da instituição. O contexto do Plano Brady permitiu que o tema voltasse à pauta.

Em novembro de 1989, o diretor executivo dos EUA apresentou aos colegas a intenção do governo norte-americano de aumentar o capital do Fundo em 35\%. Foi apoiado 
pelos colegas do Reino Unido e da Arábia Saudita. Todos os outros — representando 70\% do poder de voto da instituição - defenderam um aumento de 100\%. Em março de 1990, chegou-se a um acordo e decidiu-se aumentar o capital da instituição em 50\% (Boughton, 2001, p. 872). O aumento foi aprovado pelo Comitê Executivo em maio (ibidem, pp. 874875). A participação dos EUA no aumento de capital seria de cerca de US\$ 12 bilhões.

A tramitação do pedido de aumento de quotas mostrou, mais uma vez, a oposição quase automática do Congresso norte-americano a quaisquer operações que possam ser vistas como ajuda internacional.

Em função das eleições legislativas de novembro de 1990, o governo Bush decidiu adiar para o ano seguinte o envio do projeto de lei que apropriaria os recursos para o FMI. O governo tentou incluir o aumento na H.R. 2621, que alocava recursos para a ajuda externa, mas projeto de lei foi aprovado sem o dispositivo (Farias, 2007, p. 113). A seguir, o aumento de capital foi incluído pela comissão de conferência no texto da H.R. 2508, que autorizava o uso de recursos para ajuda internacional e que já tinha sido aprovada, tanto na Câmara quanto no Senado, sem a menção ao aumento de quotas. No entanto, o projeto incluía três dispositivos considerados inaceitáveis pelo governo, que prometeu vetar o projeto se o texto final incluísse aqueles dispositivos. A inclusão do aumento de capital do FMI também enfureceu diversos congressistas, especialmente conservadores. Por fim, o projeto foi rejeitado no plenário da Câmara por 159 votos contra 262, em uma votação que cruzou linhas partidárias (Doherty, 1991, p. 3215).

Em 1992, a proposta voltaria à pauta do Congresso. Nesse momento, a crise da dívida já perdera visibilidade e urgência, em virtude da percepção de que o Plano Brady vinha obtendo sucesso. O aumento de capital do FMI passou a ser relacionado aos programas de ajuda aos países da Europa Oriental que pertenceram ao extinto bloco soviético e aos Estados criados a partir da desintegração da União Soviética.

Mais uma vez, o aumento de capital do Fundo foi vítima das idas e vindas da política doméstica norte-americana. Em novembro de 1992, haveria eleições presidenciais, e, na contramão da tradição política norte-americana, Bush viu-se obrigado a enfrentar um opositor forte nas primárias - o jornalista conservador Patrick Buchanan. Embora vencesse todas as primárias iniciais, Bush não empolgava o eleitorado - ao passo que Buchanan, baseado em um discurso agressivo, mobilizava a base conservadora do Partido Republicano e obtinha resultados melhores do que se poderia esperar de um desafiante a um presidente em exercício. 
Até vencer definitivamente Buchanan nas primárias de Michigan e Illinois, em meados de março, Bush foi extremamente cauteloso com relação ao pedido de aumento de capital do FMI, temendo que a questão fosse transformada em tema de campanha pelo seu adversário (Greenberger, 1992).

Garantida a indicação para concorrer à reeleição, Bush passou a pressionar o Congresso para conceder os recursos ao Fundo, afirmando que eles eram essenciais para garantir a transição dos países do antigo bloco soviético para o capitalismo e a consolidação da "revolução democrática" na Rússia. "Se esta revolução democrática for derrotada", afirmou Bush, "isso poderia nos afundar em um mundo mais perigoso [...] do que os anos negros da Guerra Fria”. "Temos que agir agora", completou, pressionando o Congresso (Seib e Harwood, 1992).

A visita do presidente Boris Yeltsin a Washington, em meados de junho, abriu o caminho para a aprovação do projeto. Yeltsin discursou no Capitólio em sessão conjunta da Câmara e do Senado em 17 de junho e, no dia seguinte, a comissão de Bancos da Câmara aprovou um amplo projeto de ajuda internacional (H.R. 3428), que incluía o aumento de capital do FMI. Depois da votação, o líder da minoria na comissão, Chalmers Wylie (republicano de Ohio), afirmou que o projeto tinha sido aprovado porque "Yeltsin fez um grande discurso", completando que "nesse negócio, momento e circunstâncias são tudo" (Cranford, 1992, p. 1780, Hitt, 1992).

Em 25 de setembro, a legislação que aumentava o capital do FMI foi incorporada pela comissão de Apropriações do Senado à H.R. 5368, um projeto já aprovado pelo plenário da Câmara que apropriava US\$ 26,4 bilhões em ajuda internacional (além dos US\$ 12 bilhões autorizados para o FMI). A H.R. 5368 foi aprovada pelo plenário do Senado em $1^{\circ}$ de outubro, por margem folgada de 87 a 12 votos. Como a versão modificada pelo Senado diferia da aprovada pela Câmara, o texto foi enviado para conferência. Apenas quatro dias depois, em 5 de outubro, o texto final foi aprovado pela Câmara por 312 a 105 votos, em no Senado por aclamação (voice vote). No dia seguinte, foi sancionada pelo presidente como Public Law 102-391 (Rogers, 1992). 


\section{Conclusão}

Neste trabalho, procurei testar a hipótese de que um determinante importante da delegação da crise da dívida dos anos 80 para o Fundo Monetário Internacional teve origem na política doméstica norte-americana. Até que ponto a pesquisa empírica confirma os preceitos da teoria?

A hipótese baseia-se no argumento teórico de que a delegação de um tema para uma organização internacional aumenta a autonomia do ator que delega (geralmente o poder executivo) em relação aos outros atores políticos domésticos. Este aumento de autonomia do ator delegante com relação aos outros atores domésticos (o principal na relação principalagente estabelecida com a organização internacional) se deve ao fato de que a delegação desloca o poder de agenda sobre o tema para a organização internacional, reduz o número de pontos de decisão doméstica, cria assimetrias de informação em favor do delegante, e aumenta a legitimidade das políticas defendidas pelo delegante. Por outro lado, como a organização é uma entidade independente do Poder Executivo, a delegação implica nos custos causados pela perda de poder do principal de atuar diretamente sobre o tema (perdas de agência) e pelos custos que o delegante incorre para supervisionar a organização (custos de agência). Dessa forma, tenderá a haver tanto mais delegação de temas a organizações internacionais quanto maior for o "lucro" representado pelo aumento de autonomia do ator delegante menos os custos causados pela delegação.

Para o caso particular em que o hegemon em um tema tenha de decidir se delega ou não seu tratamento para uma organização internacional, a teoria aponta que a delegação será tanto mais provável quanto maior for a controvérsia sobre o tema em seu sistema político doméstico. Em outros termos, quanto maior for assertividade (entendida como intensidade de preferências e desejo de influir no tratamento de uma questão) dos outros atores políticos domésticos sobre um tema, maior será a propensão do Executivo em delegá-lo para organizações internacionais.

Esta pesquisa procurou mostrar que a crise da dívida dos anos 80 foi, do ponto de vista do Poder Executivo dos EUA, uma crise bancária que poderia ser tratada exclusivamente no nível doméstico. Seu tratamento como crise internacional delegada ao Fundo Monetário 
Internacional decorreu de um cálculo de custo-benefício que levou em conta, em grande medida, determinantes domésticos. O trabalho procurou mostrar que, entre 1982 e 1989, o tratamento a ser dado à crise da dívida foi objeto de intensa controvérsia no âmbito doméstico norte-americano, e que a delegação da crise ao FMI aumentou a autonomia do Executivo (em particular, do Departamento do Tesouro) sobre o tema com relação ao Congresso. As seções seguintes sumarizam esses argumentos.

\subsection{A CRISE DA DÍVIDA: UMA CRISE BANCÁRIA NORTE-AMERICANA}

A despeito de a crise da dívida ter se iniciado com a ameaça de default de um país soberano (México, em agosto em 1982), o episódio foi essencialmente o resultado de uma bolha financeira liderada por bancos norte-americanos. Era grande o risco de que, caso o default do México se concretizasse, sobreviesse uma crise bancária nos EUA, com a quebra de um ou mais grandes bancos e a necessidade de intervenção do Federal Reserve, como emprestador de última instância, e do Tesouro, para reestruturar o sistema bancário.

Como vimos, se o default mexicano evoluísse para uma crise bancária, o Fed seria obrigado a injetar bilhões de dólares em créditos, o Tesouro teria de nacionalizar os bancos que quebrassem e promover, por meio de empréstimos, a absorção dos bancos mais frágeis pelos bancos mais fortes. As autoridades norte-americanas sabiam que teriam de nacionalizar grandes bancos caso um dos maiores devedores soberanos declarasse moratória (Isaac, 2008). Ademais, em uma economia que já patinava em uma recessão, uma crise bancária levaria o país a uma verdadeira depressão.

Um curso de ação estritamente doméstico para evitar a crise bancária seria promover um salvamento direto dos bancos norte-americanos. Como mostra Dooley, os bancos norteamericanos entenderam haver uma boa possibilidade de que seu governo os reembolsasse pelos empréstimos feitos ao Terceiro Mundo (1994, p. 7). Mesmo que tal operação implicasse em algum prejuízo para os bancos, ela eliminaria de seus balanços todos os créditos cujo repagamento era duvidoso e reduziria drasticamente a incerteza sobre a solidez dos bancos. Ao governo norte-americano ficaria o "mico": cobrar, de outros Estados soberanos, os empréstimos que tinham sido contraídos junto aos bancos. Outra operação estritamente doméstica que poderia ter sido feita era a injeção de recursos públicos nos bancos, em troca de ações. Ambas as operações exigiriam aprovação do Congresso - o que poderia levar meses - e implicariam em enorme desgate político, com o Executivo sendo acusado por anos 
de ter "salvado os grandes bancos" com o dinheiro do contribuinte, já em dificuldades por causa da recessão.

A partir dos elementos obtidos nesta pesquisa, não é possível sequer afirmar com alguma certeza que o Congresso aprovaria tais operações. Por conta da valorização do dólar e da recessão do início dos anos 80, o setor industrial já passava por muitas dificuldades. Seria uma proeza política justificar um salvamento do setor financeiro enquanto a indústria passava por dificuldades. Podemos afirmar, de qualquer forma, que o Executivo certamente poderia antecipar que, caso conseguisse persuadir o Congresso de que a ajuda ao setor financeiro era essencial para evitar um aprofundamento da recessão, a condição exigida seria a imposição de pesadas perdas aos grandes bancos.

Tratar o problema no nível externo, portanto, aparecia como a solução mais barata. Impedindo-se os países de declarar default, se evitaria que o problema evoluísse para uma crise bancária. O custo seria menor do que o das alternativas domésticas, pois bastaria emprestar, aos países devedores, recursos suficientes para continuarem a pagar os serviços de suas dívidas. Isso seria feito com uma combinação de recursos públicos e privados.

\subsubsection{EMPRESTAdORES DE ÚlTIMA INSTÂNCIA: TESOURO E FED}

A pesquisa mostra que o Departamento do Tesouro e o Federal Reserve atuaram como emprestadores de última instância para o México, em agosto de 1982. Em um final de semana, os dois órgãos levantaram quase US\$ 4 bilhões em empréstimos de curto prazo para o governo mexicano. O episódio do Mexican weekend também mostra que os próprios países devedores sabiam que o estabilizador do sistema financeiro era o governo norte-americano, pois as autoridades mexicanas procuraram primeiro o Tesouro para pedir ajuda. O Brasil faria o mesmo, poucas semanas depois. O FMI não tinha agilidade suficiente para cumprir o papel de estabilização de curto prazo.

Note-se também que uma operação como a do México, no qual um volume de recursos sem precedente no pós-guerra foi mobilizado com extrema celeridade, não poderia se repetir para outros países devedores em dificuldades. O México, pelo fato de fazer fronteira com os EUA, dispunha de tratamento diferenciado no sistema político norte-americano. Seria muito mais difícil para Donald Regan passar por cima da decisão do OMB de tentar extrair os termos mais punitivos possíveis se o país em questão não fosse o México (supra, p. 88); como vimos, os tomadores de decisão no Poder Executivo acreditavam que o Congresso apoiaria 
uma iniciativa de ajuda ao México se temesse a possibilidade de colapso econômico do país vizinho (supra, p. 100 e seguintes). O mesmo não pode ser dito do Brasil ou da Argentina, que, apesar de possuírem grandes economias, estão muito mais distantes do território norteamericano.

\subsection{A SOLUÇÃO DE LONGO PRAZO: O FMI}

Um pacote como o montado em agosto de 1982 para o México poderia resolver o problema imediato, mas não serviria como solução de longo prazo. Os recursos à disposição do Fed e do Tesouro eram limitados e só poderiam ser empregados em operações de curto prazo. O risco sistêmico persistia. A solução de longo prazo seria reduzir gradativamente a exposição dos bancos norte-americanos (particularmente dos money center banks, que estavam mais expostos) aos países do Terceiro Mundo. Como a capacidade de geração de superávits comerciais dos países em desenvolvimento não lhes permitiria pagar de volta os empréstimos que haviam tomado junto aos bancos, a redução da exposição dos grandes bancos exigiria uma gradual transferência de risco dos credores privados para credores oficiais.

O problema, porém, era que tal transferência seria extremamente custosa, em termos de capital político do governo, se feita no âmbito exclusivo do sistema doméstico norteamericano. Por isso, a delegação ao FMI serviu como alternativa que permitia ao governo empreender a operação de salvamento do sistema bancário, minimizando a influência do Congresso.

\subsubsection{VANTAGENS DA DELEGAÇÃO AO FMI}

A partir das categorias teóricas desenvolvidas por Andrew Moravcsik e apresentadas no segundo capítulo, podemos afirmar que a delegação da crise da dívida para o FMI aumentou a autonomia do Poder Executivo norte-americano de três maneiras: deslocou o poder de agenda de forma favorável ao governo, reduziu a quantidade de pontos de decisão nos quais o Congresso poderia intervir no tratamento do problema e aumentou a legitimidade da política adotada para o tema. A pesquisa, no entanto, não indicou que a delegação tenha criado vantagens relevantes no que tange à criação de assimetrias de informação — quarta categoria proposta por Moravcsik. 


\section{Deslocamento do poder de agenda}

A delegação da gestão da crise da dívida para o FMI reduziu sobremaneira o poder do Congresso de intervir diretamente no tema. Os sucessivos processos de renegociação foram feitos diretamente entre os bancos credores e os países devedores, tendo o FMI como intermediário. Como tanto os países devedores quanto o FMI são entidades soberanas, restou ao Congresso tentar influir no comportamento do único ator submetido à legislação norteamericana: os bancos. Isto foi tentado em 1983, por meio da Lei de Supervisão de Empréstimos Internacionais, incluída no aumento de capital do FMI.

Quando ficou mais clara a associação entre a crise da dívida e a redução da competitividade comercial norte-americana, o Congresso viu-se impedido de influir diretamente na questão porque ela estava a cargo do FMI, imune à jurisdição do Congresso. Restava aos congressistas inserir "recomendações" ao diretor executivo dos EUA junto ao Fundo - um processo indireto de influência e sujeito à interferência do próprio Executivo, já que é o secretário do Tesouro que indica o diretor executivo dos EUA junto aos organismos financeiros multilaterais.

Por fim, a delegação da gestão da crise ao FMI facilitou ao Poder Executivo tomar a iniciativa política quando se viu ameaçado pelo ativismo congressual. Isto se deu em 1985 (Plano Baker) e 1989 (Plano Brady). Nos dois casos, para manter a iniciativa sobre a crise da dívida o secretário do Tesouro anunciou um grande e ambicioso plano que exigia o desembolso de recursos por parte do FMI. O sucesso do plano, portanto, dependia da aprovação do FMI. Nas duas oportunidades, o Congresso viu-se confrontado com uma opção entre um status quo inadequado e um plano que, ainda que não fosse perfeito, era o único que poderia ser executado em prazo razoável. Se o Congresso não aceitasse o plano apresentado, teria de tentar aprovar legislação que obrigasse o Tesouro a exigir uma mudança nas políticas do FMI. Tal medida teria perspectivas no mínimo duvidosas de sucesso, já que o FMI possuiria fortes incentivos para resistir às mudanças de políticas exigidas pelo Congresso, sabendo que o próprio Tesouro se opunha tais mudanças.

Isto explica por que a principal proposta de mudança na política para a crise da dívida baseou-se na criação de uma nova agência internacional, a Autoridade para o Gerenciamento da Dívida Internacional (IDMA): era mais fácil criar uma nova organização do zero do que mudar o comportamento de uma organização já fortemente institucionalizada e que possuía fortes incentivos para resistir a qualquer alteração que não fosse oriunda de quem realmente 
lhe delegara a gestão da crise - o Executivo norte-americano. A credibilidade da ameaça de obrigar o governo a criar a IDMA levou o Tesouro a finalmente aquiescer com a introdução de elementos de alívio da dívida em sua estratégia, mas o fez de forma muito mais moderada do que a proposta original do Congresso. Como o poder de agenda estava fortemente deslocado a favor do Tesouro, a proposta moderada do Plano Brady acabou sendo preferível, para os congressistas, do que entrar em conflito com o governo para tentar criar a IDMA e forçar uma mudança mais profunda na política para a dívida.

\section{Redução de pontos de decisão do Congresso}

Outro efeito da delegação da gestão da crise da dívida para o FMI foi impedir o Congresso de interferir em decisões individuais de empréstimo. Note-se que, na montagem do pacote para o México, a possível reação do Congresso ao apoio ao país vizinho foi levada em conta pelas autoridades do governo. A percepção no governo era que quanto mais longe da fronteira estivesse um país devedor, mais difícil seria a aprovação do Congresso a um pacote de ajuda para ele. A delegação da condução dos processos de renegociação para o Fundo impediu o Congresso de tentar influir em alguma decisão individual.

A rigor, o Congresso teve apenas três oportunidades de influenciar diretamente a estratégia montada pelo governo para a crise: (i) a votação do aumento de capital do Fundo em 1983, (ii) a H.R.3, aprovada em 1988, que exigiu que o Tesouro estudasse a criação de uma Autoridade para o Gerenciamento da Dívida Internacional (IDMA), e (iii) a votação do aumento do capital do Banco Mundial, também em 1988. Destas, a mais importante foi a referente ao aumento do capital do Fundo, pois se tratava de aceitar ou rejeitar a Estratégia dos Cinco Pontos. A estratégia foi apresentada em um único pacote, do estilo tomar-ou-largar, no qual o Congresso era chamado a aprovar uma autorização de recursos para uma organização internacional, que por sua vez poderia utilizar esses recursos sem reportar-se diretamente ao Congresso. As dificuldades que o governo enfrentou para aprovar o aumento de cotas mostram o desconforto que a proposta causou no Congresso. Liberais e conservadores discordaram dos motivos, mas concordaram em que o aumento de cotas do FMI era inadequado. A aprovação do projeto só foi obtida porque o governo fez diversas concessões e concordou em incluir, na mesma legislação, outras medidas de interesse de grupos específicos, como a Lei de Habitação, que não tinham relação com o Fundo ou com o tema da dívida externa. O pedido de aumento do capital do Banco Mundial ofereceu 
oportunidade para os congressistas manifestarem sua insatisfação com a abordagem vigente para a dívida, mas a estratégia do governo não chegou a estar sob risco: mesmo que o pedido fosse rejeitado pelo Legislativo, a estratégia permaneceria a mesma. A H.R. 3, por outro lado, representou a maior ameaça à abordagem preferida pelo governo. Houve a possibilidade real de que a legislação forçasse o governo a criar uma nova organização para gerir a dívida internacional e, assim, pusesse um fim à Estratégia dos Cinco Pontos. A tramitação do projeto, porém, foi tão demorada que o Executivo teve tempo de preparar uma resposta, que seria anunciada em março de 1989 por Nicholas Brady e que evitaria a criação da IDMA e manteria a gestão da crise nas mãos do Fundo.

\section{Aumento da legitimidade da política adotada}

O FMI foi fundamental para dar uma aparência técnica a um problema essencialmente político. No centro da Estratégia dos Cinco Pontos, estava uma decisão essencialmente política: caberia aos países devedores gerar superávits comerciais para manter os pagamentos do serviço de suas dívidas em dia. O papel do Fundo era atestar que os países devedores estavam efetivamente realizando ajustes econômicos que lhes permitiriam, pelo menos em tese, obter tais superávits e complementar as necessidades de recursos dos devedores com seus próprios fundos.

O FMI, dessa forma, representou a institucionalização da idéia de que era necessário que os países devedores empreendessem ajustes econômicos como forma de restabelecer o equilíbrio de suas contas externas. Essa visão começaria a ser questionada a partir de 1986, quando se passou a associar a geração de superávits comerciais dos devedores com os déficits comerciais dos EUA, em particular com a queda das receitas da indústria e da agricultura norte-americanas.

Foi possível verificar, nos debates no âmbito do Congresso, que o papel do Fundo como fiscalizador das políticas econômicas dos países devedores conferia-lhe algum respeito. Esse papel do FMI como agência de classificação ou consultoria de ajustes econômicos não era, no entanto, o mais importante; seu papel mais importante foi o de complementar, com seus fundos, os pacotes de reestruturação das dívidas. De fato, o papel de físcalizador subordinava-se ao papel de emprestador, e diversas vezes o Fundo liberou recursos a países devedores que não estavam estritamente em dia com as condições que tinham sido acordadas. A combinação dos dois papéis - fiscalizador de políticas e emprestador de recursos - 
facilitou a execução da Estratégia dos Cinco Pontos, pois associou os empréstimos realizados pelo Fundo a programas de ajustes econômicos que, pelo menos em abstrato, contavam com alguma simpatia do Congresso, já que representavam a correção de “distorções" que, na visão de boa parte dos congressistas, teriam causado, ou no mínimo contribuído, para a situação de crise.

\section{Assimetrias de informação}

Em termos teóricos, o quarto componente da delegação que colabora para aumentar a autonomia do Poder Executivo vis-à-vis os outros atores políticos domésticos é a criação de assimetrias de informação. Em função do status das organizações internacionais como sujeitos de Direito Internacional — imunes, portanto, à jurisdição interna dos Estadosmembros - , uma organização pode reter informações importantes, que serão compartilhadas apenas com os governos dos países-membros, mas não com outros atores.

Esta pesquisa, contudo, não identificou que a delegação da crise para o FMI tenha criado assimetrias de informação suficientes para aumentar a autonomia do Executivo. $\mathrm{O}$ Congresso foi sempre capaz de ouvir especialistas com amplo conhecimento, e as informações necessárias para a tomada de decisões, quando não eram apresentadas pelo governo, eram trazidas por empresas, entidades de classe e membros da comunidade acadêmica.

A partir de 1986, o principal elemento que norteou a atuação do Congresso foi a percepção de que a crise da dívida tinha conseqüências negativas para a indústria e a agricultura norte-americanas. Esta percepção foi corroborada por fatos e dados amplamente disponíveis para o Congresso, e apresentados em relatórios, seminários e audiências a diversas comissões.

Portanto, no caso particular objeto desta pesquisa, não foi possível identificar efeito significativo de criação de assimetrias de informação.

\subsubsection{CUSTOS DA DELEGAÇ̃̃o}

Toda delegação implica no custo, para quem delega, de ver uma tarefa ser executada de forma diferente da que ele mesmo preferiria, se executasse a tarefa diretamente. Este é o custo de agência. Se o delegante tem a opção de escolher entre diversos possíveis agentes, ele escolherá aquele que, em sua percepção, cumpra a tarefa com o menor custo de agência. 
Quanto mais alinhadas estiverem as preferências do principal com as do agente, menor será o custo de agência.

No caso da crise da dívida, o Tesouro tinha a opção entre delegar a gestão do tema para o FMI ou para o Banco Mundial. Como foi possível verificar a partir das relações entre o governo norte-americano e as duas instituições de Bretton Woods, as preferências do Fundo estavam mais alinhadas às do Tesouro do que as do Banco. O FMI oferecia um mecanismo de empréstimos condicionados a metas macroeconômicas que, ao mesmo tempo em que poderia servir para acelerar a redução da exposição dos bancos credores, era congruente com a visão econômica conservadora do governo Reagan. O mecanismo de condicionalidades do FMI poderia ser usado para promover reformas econômicas nos países do Terceiro Mundo que o governo norte-americano teria interesse em promover mesmo na ausência da crise da dívida. O Banco Mundial, por outro lado, quando a crise estourou ainda baseava sua atuação em paradigma desenvolvimentista considerado inaceitável pelas autoridades norte-americanas. Assim, embora o Banco também dispusesse de recursos que poderiam ser utilizados na estratégia da dívida, foi deixado de lado até o final de 1985 e, de qualquer forma, nunca teve posição central no tema.

Por fim, a pesquisa também indicou que o custo de agência da delegação para o FMI era bem mais baixo do que a vantagem, para o Executivo, de aumentar sua autonomia no nível doméstico no tratamento do problema da dívida. Isto se deve, em certa medida, ao fato de que a direção do FMI era flexível a demandas do governo norte-americano. É verdade que, em decisões individuais de empréstimo, muitas vezes o FMI mostrou-se mais rígido do que o Tesouro, exigindo garantias ou condições que o próprio governo norte-americano preferiria que fossem deixadas de lado. No entanto, no que tange à estratégia mais ampla, o FMI mostrou-se flexível às mudanças de discurso e de abordagem empreendidas pelo governo. Em 1985, após o anúncio do Plano Baker, o FMI passou a incluir a "retomada do crescimento sustentável" dos países devedores em seu discurso; em 1989, a direção do Fundo foi rápida em aprovar o Plano Brady, embora a nova iniciativa do Tesouro incluísse a possibilidade de alívio da dívida - um elemento que até então estivera ausente da abordagem vigente.

O que explica a flexibilidade do Fundo às preferências do Tesouro? Fatores estruturais, tais como o poder de veto dos EUA, a localização da sede da entidade em Washington e os procedimentos de contratação de funcionários, certamente explicam parte dessa flexibilidade. Mas outro fator parece ter contribuído: a necessidade de o FMI encontrar 
uma nova função que justificasse sua existência depois do fim do sistema de câmbio fixo de Bretton Woods, em 1971-1973. Nos anos 70, o FMI foi uma organização em busca de uma missão. Encontrou sua missão em 1982: servir como mediador entre bancos comerciais e países em desenvolvimento, intermediando transferências de recursos dos países industrializados para os devedores soberanos e, destes, para os credores privados. Ademais, o montante de fundos destinados ao FMI parece ter sido "calibrado", pelo governo norteamericano, para maximizar seu controle sobre o Fundo: a organização recebeu recursos suficientes para cumprir seu mandato, mas não o suficiente para poder distanciar suas atividades das preferências do Departamento do Tesouro. Nas duas vezes, entre 1982 e 1992, em que o capital do FMI foi ampliado, os outros países industrializados queriam aumentos de $100 \%$ ou $200 \%$, ao passo que os EUA só permitiram aumentos bem menores. Por fim, os EUA também vetaram propostas de permitir que o Fundo se financiasse no mercado privado, o que conferiria muito mais independência à entidade.

\subsection{O PAPEL DO BANCO MUNDIAL}

O Banco Mundial foi um coadjuvante na crise da dívida. Foi ignorado pelo governo norte-americano em 1982, quando foi montada a Estratégia dos Cinco Pontos, e só passaria a ser parte da gestão da crise da dívida depois que A. W. Clausen modificou as políticas do Banco, alinhando-as às preferências do Tesouro e abandonando a abordagem baseada na Economia do Desenvolvimento, que marcara sua atuação na gestão de Robert McNamara.

O Plano Baker introduziu o Banco Mundial na estratégia de gestão da crise da dívida. Seu papel, no entanto, não era central como era o do FMI. Durante todo o período objeto desta pesquisa, o Banco só emprestou recursos para países que já possuíssem um acordo com o FMI em vigor. Seu papel foi, essencialmente, de atuar como "fundo de reserva" da estratégia do Tesouro para a dívida, complementando, com sua grande capacidade financeira, os recursos que faltavam para as operações de renegociação de dívida. O Plano Brady, embora contasse com os recursos do Banco, não mudaria sua posição subordinada.

O Banco Mundial deixou de servir como entidade auxiliar do FMI apenas uma vez, na operação realizada com a Argentina em 1988 (supra, p. 222). Naquela situação, como se recorda, o Fundo exigia, como condição para fechar um novo acordo de empréstimo, que o país realizasse uma redução do déficit público que o governo argentino julgava impossível lograr. Temendo as consequiências de um default argentino, o Tesouro passou a pressionar o 
Fundo a assinar um acordo de qualquer forma. A resistência do FMI causou um mal-estar entre o organismo e o Tesouro, cujas autoridades começaram a criticar Camdessus, acusandoo de tentar usar o episódio para aumentar a independência do Fundo na gestão da crise. A solução definitiva foi anunciada no final de setembro: um surpreendente acordo da Argentina com o Banco Mundial no qual o país receberia um empréstimo de US\$ 1,25 bilhão. A ocasião serviu para o Departamento do Tesouro reafirmar seu controle sobre o FMI, indicando que possuía alternativas para a gestão da crise. Depois do episódio, o conflito com o Fundo não mais se repetiu e o Banco voltou a uma posição secundária.

\subsection{O FMI E OS OUTROS GOVERNOS}

Esta pesquisa concentrou-se nos determinantes oriundos da política doméstica norteamericana da delegação da crise da dívida para o FMI. A posição dos outros governos não foi objeto deste trabalho. No entanto, algumas considerações são pertinentes porque se relacionam ao principal argumento teórico que procura explicar, com base em fatores exclusivamente de política internacional, a delegação de crises financeiras ao FMI: o de que apenas o FMI, por ser uma organização multilateral, teria legitimidade política para atuar como fator de coerção dos países devedores, exigindo deles condições que seriam inaceitáveis se fossem exigidas diretamente por um governo estrangeiro ou por entidades privadas.

Esta pesquisa aponta que, desde a primeira crise do México, em agosto de 1982, as autoridades financeiras dos países devedores procuravam inicialmente o governo dos EUA, batendo às portas do FMI por exigência das autoridades norte-americanas. Desde o primeiro momento, esteve claro para os governos dos países devedores que o FMI era apenas um intermediário, mas que os verdadeiros tomadores de decisão estavam a algumas quadras de distância, no Departamento do Tesouro. Tampouco parece que os governos da região preferiam tratar com o FMI a tratar com o Tesouro; a exigência de Bresser Pereira, em 1987, de que o FMI fosse excluído das negociações para que o País encerrasse a moratória indica que ocorria exatamente o contrário.

Ademais, a pesquisa também revela que o grau de disposição dos países devedores em romper com a estratégia montada pelo governo norte-americano para a dívida era pequena. Ameaças de default, como as do México em 1982 e 1986 - e mesmo a moratória brasileira - , foram manobras negociadoras para tentar obter melhores termos do governo dos EUA e dos bancos credores. 
Pressionados por ambientes políticos domésticos instáveis e incapazes de unirem forças para melhorarem sua precária situação negociadora, os países devedores nunca representaram uma verdadeira ameaça à estratégia do governo norte-americano para a crise da dívida. As principais ameaças a esta estratégia não tiveram origem nas capitais da América Latina, mas sim em Washington - mais precisamente, no Capitólio. A delegação do dia-adia das negociações com os países devedores e com os bancos credores ao FMI serviu para o governo norte-americano esquivar-se das tentativas do Congresso de influir decisivamente no assunto, permitindo-lhe executar essencialmente uma mesma estratégia durante toda a crise da dívida. 


\section{Referências}

ABBOTT, Kenneth W., SNIDAL, Duncan. (1998). "Why states act through formal international organizations". The Journal of Conflict Resolution, Vol. 42, No. 1.

ABBOTT, Kenneth W., KEOHANE, Robert O., MORAVCSIK, Andrew, SLAUGHTER, Anne-Marie, SNIDAL, Duncan (2000). “The concept of legalization”. International Organization, Vol. 54, No. 3.

AGGARWAL, Vinod K. (1996). Debt games: strategic interaction in international debt rescheduling. Cambridge: Cambridge University Press.

ALLEN, Ira R. (1983). "Reagan chastizes GOP foes on IMF aid". United Press International, August 2.

ALTER, Karen. (2006). "Delegation to international courts and the limits of re-contracting political power”, in HAWKINS, Darren G., LAKE, David A., NIELSON, Daniel L., TIERNEY, Michael J. (eds.), Delegation and agency in international organizations. Cambridge: Cambridge University Press.

ALVAREZ, Lizette. (1995). "Visiting Castro to Meet Both Cold Shoulder and 'Fidelmania"”. The New York Times, 20 de outubro.

ANDREWS, Edmund L. (2008). “Fed's $\$ 85$ billion loan rescues insurer”, The New York Times, 17 de setembro.

ASSOCIATED PRESS. (1982). "U.S. assumes villain role at world financial conference”, 8 de setembro.

ATKINSON, Caroline, ROWE Jr, James L. (1982a). "Can't pay debt, Argentina confirms", The Washington Post, $1^{\mathrm{o}}$ de setembro, p. D7.

ATKINSON, Caroline, ROWE Jr, James L. (1982b). "Mexico surprised U.S. with nationalization", The Washington Post, 2 de setembro, p. C13.

AUERBACH, Stuart. (1984). "U.S. firms struggle under strong dollar", The Washington Post, 18 de novembro, p. F1.

AUERBACH, Stuart. (1985). "'84 deficit in trade a Record; Hits \$123 billion; Import surge seen continuing in '85', The Washington Post, 31 de janeiro, p. A1.

BACHA, Edmar L. (1988). "Entre a acomodação e o confronto: os dilemas da renegociação da dívida externa brasileira, 1983-1987’. Revista de Economia Política, vol. 8, no. 2, abril/junho/1988.

BALLA, Steven J. (1998). "Administrative procedures and political control of the bureaucracy". The American Political Science Review, Vol. 92, No. 3. 
BANKER, The. (1983). “Unlikely alliance against the IMF”. Agosto de 1983, p. 7.

BARNETT, Michael N., FINNEMORE, Martha. (1999). "The politics, power, and pathologies of international organizations". International Organization, Vol. 53, No. 4.

BATISTA JR., Paulo Nogueira. (1988). Da crise econômica internacional à moratória brasileira. Rio de Janeiro: Paz e Terra.

BENDOR, J., GLAZER, A., HAMMOND, T. (2001). “Theories of delegation”. Annual Review of Political Science, Vol. 4.

BENNETT, Robert A. (1982). "I.M.F. plans pressure on banks to help Brazil”, The New York Times, 15 de dezembro.

BERG, Eric, (1987). "Citicorp accepts a big loss linked to foreign loans", The New York Times, 20 de maio, p. A-1.

BERNHARD, William. (2002). "Why delegate: the international and domestic causes of delegation". Paper preparado para a Conference on Delegation to International Organizations, 2002, Cambridge, MA.

BERNHARD, William, BROZ, J. Lawrence, CLARK, William R. (2002). “The political economy of monetary institutions”. International Organization, Vol. 56, No. 4.

BIRD, Graham. (1996). "The International Monetary Fund and developing countries: a review of the evidence and policy options". International Organization, Vol. 50, No. 3.

BLOOMFIELD, Arthur I. (1944). "Operations of the American Exchange Stabilization Fund”. The Review of Economics and Statistics, Vol. 26, No. 2, May.

BOARD OF GOVERNORS OF THE FEDERAL RESERVE SYSTEM. (2005). The Federal Reserve System: Purposes and Functions. Washington, D.C.

BOGDANOWICZ-BINDERT, Christine A. (1985). "World debt: the United States reconsiders". Foreign Affairs, Vol. 64, No. 2.

BORDO, Michael, JAMES, Harold. (2000). "The International Monetary Fund: its present role in historical perspective". NBER Working Paper 7724.

BOUGHTON, James M. (1997). "From Suez to Tequila: the IMF as crisis manager". IMF Working Paper, July.

BOUGHTON, James M. (2000). "Michel Camdessus at the IMF at 60: a retrospective". Finance and Development, Março.

BOUGHTON, James M. (2001). Silent revolution: the International Monetary Fund, 1979(1989). Washington: International Monetary Fund. 
BOUGHTON, James M. (2005). "Does the world need a universal financial institution?". IMF Working Paper.

BRADLEY, Bill. (1982). "Lending risks in the developing world". Congressional Record, Senado, 20 de setembro de 1982, pp. 24164-24166.

BRADY, Nicholas F. (1989). "Dealing with the internationa debt crisis". Discurso proferido na conferência sobre a dívida do Terceiro Mundo organizada pela Brookings Institution e pelo Bretton Woods Committee em 10 de março de 1989. US Department of State Bulletin, maio.

BRANIGIN, William. (1989). "Mexico, IMF reach accord on $\$ 3.63$ billion loan plan; pact called 1st support of debt-cut demands", The Washington Post, 12 de abril.

BRESSER PEREIRA, Luiz Carlos. (1992). "Contra a corrente no Ministério da Fazenda". Revista Brasileira de Ciências Sociais, Vol. 19, No. 7, julho.

BRESSER PEREIRA, Luiz Carlos. (1999). "A turning point on the debt crisis: Brazil, the US Treasury, and the World Bank". Revista de Economia Política, Vol. 19, No. 2.

BROAD, Robin. (1987). "How about a real solution to Third World debt?" The New York Times, 28 de setembro.

BROADDUS, J. Alfred e GOODFRIEND, Marvin. (1996). "Foreign exchange operations and the Federal Reserve". Economic Quarterly, Federal Reserve Bank of Richmond, Vol. 82, No. 1.

BRODER, David S. (1982). "President wins toughest vote of his term", The Washington Post, 20 de agosto, p. A1.

BROZ, J. Lawrence. (1999). "Origins of the Federal Reserve: international incentives and the domestic free-rider problem”. International Organization, Vol. 53, No. 1.

BRUNE, Nancy, GARRETT, Geoffrey, KOGUT, Bruce. (2004). "The International Monetary Fund and the global spread of liberalization”. IMF Staff Papers, Vol. 51, No. 2.

BUIRA, Ariel. (1995). "Reflections on the international monetary system". Essays in international finance, No. 195. Princeton: Princeton University, Department of Economics, January.

BULOW, Jeremy, ROGOFF, Kenneth. (1991). "Sovereign debt repurchases: no cure for overhang". The Quarterly Journal of Economics, Novembro.

BUSINESS WEEK. (1982). "The burden shifts to the IMF”, 13 de setembro, p. 30.

BUSINESS WEEK. (1984). "Debtor nations throw down the gauntlet — gently", 9 de julho, p. 98.

BUSINESS WEEK. (1985a). "The momentum for an import surcharge", 11 de fevereiro, p. 133. 
BUSINESS WEEK. (1985b). “The trade deficit's toll on GNP”, 12 de agosto, p. 15.

BYRON, Christopher. (1982). "Why bankers have the jitters". Time, 20 de setembro.

CALVERT, Randall L., McCUBBINS, Mathew D., WEINGAST, Barry R. (1989). "Theory of political control and agency discretion". American Journal of Political Science, Vol. 33, No. 3 .

CARNEIRO DOS SANTOS, Gilton. (1991). "Os bancos credores e a dívida brasileira”. Revista de Economia Política, Vol. 11, No. 2.

CHRISTIAN SCIENCE MONITOR. (1988). "Give the bank its money”, 17 de junho.

CQ WEEKLY ONLINE (1985). "New Plan to Help Debtor Nations Unveiled”. October 12, 1985, pp. 2084-2085. Disponível em <http://library.cqpress.com/cqweekly/WR099405538>. Acesso em 28/09/2009.

CRANFORD, John R., FELTON, John (1988). "Hill Moves Forward on World Bank Funding”. CQ Weekly Online, September 24, p. 2660. Disponível em <http://library.cqpress.com/cqweekly/WR100404531>. Acesso em 28/09/2009.

CRANFORD, John R. (1992). “Development Banks: \$12 Billion IMF Increase Wins House Banking Approval”. CQ Weekly Online, June 20, pp. 1780-1781. Disponível em <http://library.cqpress.com/cqweekly/WR102407257>. Acesso em 28/09/2009.

DUNNE, Nancy. (1988). "Volcker urges an increase in capital for World Bank", The Financial Post, 26 de julho.

CLAENSSENS, Stijn, OKS, Daniel, WIJNBERGEN, Sweder van. (1993). “Interest rates, growth, and external debt: the macroeconomic impact of Mexico's Brady deal”. World Bank Policy Research Working Paper 1147.

CLAENSSENS, Stijn, WIJNBERGEN, Sweder van. (1993). "Secondary market prices and Mexico's Brady deal”. The Quarterly Journal of Economics, Vol. 108, No. 4, novembro.

CLINE, William R. (1984). International debt: systemic risk and policy response. Washington, D.C.: Institute for International Economics.

CLINE, William R. (1995). International debt reexamined. Washington, DC: Institute for International Economics.

COHEN, Benjamin J. (1982). "Balance-of-payments financing: evolution of a regime". International Organization, Vol. 36, No. 2.

COHEN, Benjamin J. (1985). "International debt and linkage strategies: some foreign-policy implications for the United States”. International Organization, Vol. 39, No. 4.

COHEN, Benjamin J. (1986). In whose interest? International banking and American foreign policy. New Haven: Yale University Press. 
COHEN, Roger.(1987). "Brazil later this month will propose to convert half its bank debt to bonds", The Wall Street Journal, 3 de setembro, p. 3.

COHEN, Daniel. (1992). "The debt crisis: a postmortem”. NBER Macroeconomics Annual, Vol. 7.

COWAN, Edward. (1980). "McNamara planning to step down as World Bank president in a year", The New York Times, 10 de junho, p. A-1.

COX, Gary W., SHEPSLE, Kenneth. (2007). "Majority cycling and agenda manipulation: Richard McKelvey's contributions and legacy". In ALDRICH, John, ALT, James, LUPIA, Arthur (eds.), Positive changes in political science: the legacy of Richard D. McKelvey's most influential writings. Ann Arbor: University of Michigan Press.

DAVIDSON, Roger H. (1974). "Representation and committees". Annals of the American Academy of Political and Social Science, Vol. 411.

DELAMAIDE, Darrell. (1984). O choque da dívida. Rio de Janeiro: Record.

DEPARTMENT OF THE TREASURY. (1989). Interim report to the Congress concerning international discussions on an International Debt Management Authority. In U. S. House (1989b). March 1989.

DEPARTMENT OF THE TREASURY. (2009). "Duties \& functions of the U.S. Department of the Treasury". Disponível em <http://www.ustreas.gov/education/duties/>. Acesso em 03/07/2009.

DEVLIN, Robert. (1990). "From Baker to Brady: can the new plan work?" Revista de Economia Política, vol. 10, no. 2, abril-junho.

DOHERTY, Carroll J. (1991). "House Defeats Foreign Aid Bill In Shadow of Domestic Woes”. CQ Weekly Online, November 2, pp. 3215-3216. Disponível em <http://library.cqpress.com/cqweekly/WR102405200>. Acesso em 28/09/2009.

DOOLEY, Michael P. (1994). “A retrospective on the debt crisis”. NBER Working Paper 4963, dezembro.

DREHER, Axel, JENSEN, Nathan. (2005). "Independent Actor or Agent? An Empirical Analysis of the impact of US interests on IMF Conditions". Working Papers 05-118. Zurich: KOF Swiss Economic Institute.

ECONOMIST, THE. (1982a). “Allies in principle, allies in practice”, 28 de agosto.

ECONOMIST, THE. (1982b). “Argentina's economy; a fresh admission of defeat”, 28 de agosto, p. 52.

ECONOMIST, THE. (1989a). “Latin American debt; the banks' great escape”, 11 de fevereiro.

ECONOMIST, THE. (1989b). “Twins that won’t tango”, 11 de março, p. 17. 
EPSTEIN, Edward J. (1983). "Ruling the world of money”. Harpers Magazine, novembro.

FARIAS, Alex J. (2007). Influência congressual na política norte-americana para a crise da dívida: 1983-1993. Tese de doutorado. Rio de Janeiro: IUPERJ.

FARNSWORTH, Clyde. (1980). "World Bank under McNamara", The New York Times, 10 de junho, p. D-1.

FARNSWORTH, Clyde. (1981a). "U.S. rejects proposal to form World Bank energy affiliate”, The New York Times, 13 de abril, p. D-15.

FARNSWORTH, Clyde. (1981b). "Reagan cautions developing lands on economic help", The New York Times, 30 de setembro, p. A-1.

FARNSWORTH, Clyde. (1982a). "Diplomatic World Bank chief”, The New York Times, 12 de abril, p. D-1.

FARNSWORTH, Clyde. (1982b). "U.S. backs decision to raise IMF aid to poor countries", The New York Times, 5 de setembro, p. 1-1.

FARNSWORTH, Clyde. (1982c). "Size of aid to I.M.F. uncertain", The New York Times, 6 de setembro, p. 1-33.

FARNSWORTH, Clyde. (1982d). "Quick move urged to assist nations in meeting debts", The New York Times, 7 de setembro, p. A-1.

FARNSWORTH, Clyde. (1982e). "Sprinkel sees a compromise on the Fund", The New York Times, 9 de setembro, p. D25.

FARNSWORTH, Clyde. (1988). "World Bank friends talk of bolting", The New York Times, 28 de março.

FOWLER, Henry, WALKER, Charles, OWEN, Henry. (1988). "World Bank provides highreturn investment", The New York Times, 19 de junho.

FUERBRINGER, Jonathan, (1989). "Mexico reaches accord on World Bank loan", The New York Times, 18 de maio.

FEDERAL OPEN MARKET COMMITTEE (FOMC). (1982a). Transcrição da reunião de 24 de agosto de 1982.

FEDERAL OPEN MARKET COMMITTEE (FOMC). (1982b). Transcrição da reunião de 5 de outubro de 1982.

FEDERAL RESERVE. (2008). "Press release". 16 de setembro. Disponível em <http://www.federalreserve.gov/newsevents/press/other/20080916a.htm>. Acesso em 30/06/2009. 
FEDERAL RESERVE BANK OF NEW YORK. (2007). "Bank of International Settlements". Disponível em <http://www.newyorkfed.org/aboutthefed/fedpoint/fed22.html>. Acesso em 06/07/2009.

FEINBERG, Richard E. (1988). "The changing relationship between the World Bank and the International Monetary Fund”. International Organization, Vol. 42, No. 3.

FENNO, Richard F. (1973). Congressmen in committees. Boston: Little, Brown.

FEREJOHN, John, KREHBIEL, Keith. (1987). "The budget process and the size of the budget”. American Journal of Political Science, Vol. 31, No. 2, May.

FFRENCH-DAVIS, Ricardo. (1987). "Latin American debt: debtor-creditor relations". Third World Quarterly, Vol. 9, No. 4.

FISHER, Louis. (1988). "Foreign policy powers of the President and Congress". Annals of the American Academy of Political and Social Science, Vol. 499, September.

FISHER, Louis. (1989). "How tightly can Congress draw the purse strings?". The American Journal of International Law, Vol. 83, No. 4.

FOLDESSY, Edward P. (1982). "Treasury bill rates plunge amid concern over soundness of U.S. financial system", The Wall Street Journal, 20 de agosto, p. 2.

FONSECA, Roberto Gianetti da. (2002). Memórias de um trader. São Paulo: Thompson.

FRANCIS, David. (1981). "IMF stiffening its loan terms", Christian Science Monitor, 30 de setembro, p. 11.

FREEMAN, Brian M., MENDELOWITZ, Allan I. (1982). "Program in search of a policy: the Chrysler loan guarantee". Journal of Policy Analysis and Management, Vol. 1, No. 4.

FRIEDEN, Jeffry A. (1989). "Winners and losers in the Latin America debt crisis: the political implications". In STALLINGS, Barbara, KAUFMAN, Robert, Debt and democracy in Latin America. Boulder: Westview.

FRIEDMAN, Milton. (1983). Comentários feitos no seminário da Taxpayers' Foundation em Washington em 21 de setembro de (1983). Apud Smith (1984), p. 213.

FRIEDMAN, Thomas L. (1989). “Arafat visa issue again vexing U.S.”. The New York Times, 27 de agosto.

GAVIN, Michael, RODRIK, Dani. (1995). "The World Bank in Historical Perspective". The American Economic Review, Vol. 85, No. 2.

GERTH, Jeff. (1982). "Records show Citicorp acted to skirt foreign bank rules", The New York Times, 13 de setembro, p. A-1.

GLOBE AND MAIL, THE. (1982). "The shaky wicket", 10 de setembro. 
GLOBE AND MAIL, THE. (1988a). "World Bank capital boost will benefit Third World", 22 de fevereiro.

GLOBE AND MAIL, THE. (1988b). "Boost in capital enables World Bank lending to rise", 29 de abril.

GLYNN, Leonard, MA, Christopher. (1981). "Reagan vs. the World Bank". Newsweek, 21 de setembro, p. 88.

GONZALEZ, Henry M. (1982). "End the peso panic". Congressional Record, House, 14 de setembro de 1982, pp. 23479-23480.

GREENBERGER, Robert S. (1992). "IMF funding for former Soviet Union is mired in BushCongress standoff", The Wall Street Journal, 20 de março.

GREENHOUSE, Steven. (1988). "U.S. balks at plan by Monetary Fund for more revenue", The New York Times, 28 de setembro.

GREIDER, William. (1981). "The education of David Stockman”. The Atlantic Monthly, December.

HAAS, Peter M. (1992). "Introduction: Epistemic Communities and International Policy Coordination”. International Organization, Vol. 46, No. 1.

HAMM, Keith E. (1983). "Patterns of influence among committess, agencies and interest groups". Legislative Studies Quarterly, Vol. 8, No. 3.

HAMLET, Larry, KAPUR, Devesh. (2004). "Where you sit is where you stand: the behavioral impact of geography on international organizations". Paper No. 04-06. Weatherhead Center for International Affairs, Harvard University.

HARTMAN, Robert W. (1982). “Congress and budget-making”. Political Science Quarterly, Vol. 97, No. 3.

HAWKINS, Darren, LAKE, David A., NIELSON, Daniel e TIERNEY, Michael J. (2006). "Delegation under anarchy: states, international organizations, and principal-agent theory". In HAWKINS, Darren G., LAKE, David A., NIELSON, Daniel L., TIERNEY, Michael J. (eds.), Delegation and agency in international organizations. Cambridge: Cambridge University Press.

HELLEINER, Gerald K. (1986). "Policy-based program lending: a look at the Bank's new role". In FEINBERG, Richard (ed.), Between two worlds : the World Bank's next decade. New Brunswick: Transaction Books.

HELMS, Jesse. (1982). "Senate Resolution 466-Resolution relating to the Mexican crisis". Congressional Record, Senate, 15 de setembro de 1982, pp. 23635-23637.

HENNING, C. Randall, DESTLER, I. M. (1988). "From neglect to activism: American politics and the 1985 Plaza Accord". Journal of Public Policy, Vol. 8, No. 3/4. 
HEXNER, Ervin P. (1964). “The Executive Board of the International Monetary Fund: a decision-making instrument”. International Organization, Vol. 18, No. 1, Winter.

HIRCHMAN, Albert O. (1981). "The rise and decline of development economics". In Essays in Trespassing, Cambridge: Cambridge University Press.

HITT, Greg. (1992). "House panel clears funding for IMF, a boost to C.I.S. aid", The Wall Street Journal, 19 de junho.

HOGG, Sarah, WILSON-SMITH, Peter. (1988). "The IMF/World Bank meetings in Berlin: World Bank surprises with 1.25bn dollar Argentine package", The Independent, 26 de setembro, p. 18

HORMATS, Robert. (1985). "The World Economy under Stress". Foreign Affairs, Vol. 64, No. 3.

HUMPAGE, Owen F. (1994). "Institutional aspects of U.S. intervention”. Economic Review, 1994, issue Q I, Federal Reserve Bank of Cleveland.

IKENBERRY, G. John. (2003). "State power and the institutional bargain: America's ambivalent economic and security multilateralism". In FOOT, Rosemary, MacFARLANE, S. Neil, MASTANDUNO, Michael, US hegemony and international organizations. Oxford: Oxford University Press.

IKENBERRY, G. John, KUPCHAN, Charles. (1990). "Socialization and hegemonic power". International Organization, Vol. 44, No. 4.

INDEPENDENT, THE. (1988). “Outlook: World Bank takes a risk”, 27 de setembro, p. 23.

INTERNATIONAL BANKING REPORT. (1988a). "Congress cool to World Bank capital increase call", 29 de fevereiro.

INTERNATIONAL BANKING REPORT. (1988b). "Congress resists capital increase”, 9 de maio.

INTERNATIONAL BANKING REPORT. (1988c). "Stalemate on general capital increase", 23 de maio.

INTERNATIONAL MONETARY FUND. (2009). By-laws rules and regulations of the International Monetary Fund. May 2009. Disponível em

<http://www.imf.org/external/pubs/ft/bl/blcon.htm>.

ISAAC, William M. (2008). "How to save the financial system". The Wall Street Journal, 19 de setembro.

JEFFRIES, Jim. (1982). "Notes on the Mexican crisis". Congressional Record, House, 16 de setembro de 1982, pp. 24019-24021.

JOHNSON, Bryan T., SCHAEFER, Brett D. (1998). “A checklist for IMF reform”. The Heritage Foundation Backgrounder, July 16. 
KAHLER, Miles. (1985). "Politics and international debt: explaining the crisis". International Organization, Vol. 39, No. 3.

KAHLER, Miles. (2001). Leadership selection in the major multilaterals. Washington: Institute for International Economics.

KAHN, Joseph. (2000a). "Germans try a second run at I.M.F. post". The New York Times, 9 de março

KAHN, Joseph. (2000b). "German cleared to head I.M.F. as rivals bow out". The New York Times, 17 de março

KENEN, Peter B. (1983). "Third-World debt: sharing the burden. A bailout plan for the banks". The New York Times, 6 de março.

KENEN, Peter B. (1990). "Organizing debt relief: the need for a new institution”. The Journal of Economic Perspectives, Vol. 4, No. 1.

KEOHANE, Robert O. (1975). "International organization and the crisis of interdependence". International Organization, Vol. 29, No. 2.

KEOHANE, Robert O. (1984). After hegemony: cooperation and discord in the world political economy. Princeton: Princeton University Press.

KEOHANE, Robert O., MARTIN, Lisa L. (1999). "Institutional Theory, Endogeneity, and Delegation". Paper preparado para o seminário "Progress in International Relations Theory: A Collaborative Assessment and Application of Imke Lakatos's Methodology of Scientific Research Programs", realizado em 15 e 16 de janeiro de 1999 em Scottsdale, Arizona.

KIEWIET, D. Roderick, McCUBBINS, Mathew D. (1991). The logic of delegation. Chicago: University of Chicago Press.

KILBORN, Peter. (1985). “Reagan's turnablout on the dollar”, The New York Times, 29 de setembro, p. 3-1.

KILBORN, Peter, (1989). "Mexico is given approval for $\$ 4.08$ billion I.M.F. loan", The New York Times, 27 de maio.

KINDLEBERGER, Charles P. (1951). “Bretton Woods reappraised”. International Organization, Vol. 5, No. 1.

KINDLEBERGER, Charles P. (1973). The world in depression, 1929-1939. Berkeley: University of California Press.

KINDLEBERGER, Charles P. (2000). Manias, pânicos e crashes: um histórico das crises financeiras. Rio de Janeiro: Nova Fronteira.

KISSINGER, Henry A. (1983). "How to save the world economy". Newsweek, 24 de janeiro. 
KLEPAK, Hal. (2003). "Power multiplied or power restrained? The United States and multilateral institutions in the Americas". In FOOT, Rosemary, MacFARLANE, S. Neil, MASTANDUNO, Michael, US hegemony and international organizations. Oxford: Oxford University Press.

KLUTZNICK, Philip. (1988). “A boost for the World Bank: Congress shouldn't hesitate”, The Washington Post, 29 de setembro.

KOELLE, Martin. (1988). “Congress and the World Bank”, The Washington Post, 14 de junho.

KRAFT, Joseph. (1984). The Mexican Rescue. Nova York: Group of Thirty.

KRAMER, Larry. (1982). “Citibank's transactions questioned”, The Washington Post, 18 de setembro, p. A1.

KRATOCHWIL, Friedich, RUGGIE, John Gerard. (1986). "International organization: a state of the art on an art of the state". International Organization, Vol. 40. No. 4.

KUCZYNSKI, Pedro Pablo. (1982). "Latin American debt”. Foreign Affairs, vol. 61, no. 2.

KUCZYNSKI, Pedro Pablo. (1988). Latin American debt. Baltimore: Johns Hopkins Press.

LEECH, Dennis. (2002). "Voting power in the governance of the International Monetary Fund". Annals of Operations Research, Vol. 109, pp. 375-397.

LEECH, Dennis, LEECH, Robert. (2005). "Voting power in the Bretton Woods institutions". Warwick Economic Research Papers, No. 718.

LEHMAN, Howard P. (1994). "International creditors and the Third World: strategies and policies from Baker to Brady". The Journal of Developing Areas, Vol. 28, No. 2.

LEVY, Paulo Mansur. (1993). "Mexico - the remaking of an economy". Pesquisa e Planejamento Econômico, Vol. 23, No. 2, agosto.

LEWIS, Paul. (1983). “Allies pressing U.S. on IMF bill”, The New York Times, 16 de setembro, p. D-4.

LEWIS, Paul. (1988a). "U.S. assailed at World Court on P.L.O. office”. The New York Times, 12 de abril.

LEWIS, Paul. (1988b). "U.S. loses ruling in World Court on P.L.O. mission". The New York Times, 27 de abril.

LEWIS, Paul. (1988c). "World Bank criticizes lad in Third World aid". The New York Times, 17 de maio.

LEWIS, Paul. (1988). "U.N. votes to move session to Geneva". The New York Times, 3 de dezembro, Section 1, Page 1. 
LICHTEINSTEIN, Cynthia C. (1990). "A resposta dos EUA à crise internacional da dívida. A Lei de Supervisão de Empréstimos Internacionais de 1983 e sua regulamentação". In ESKRIDGE, William N., Dança à beira do abismo: as dimensões políticas e econômicas do problema da dívida internacional, Rio de Janeiro: Forense Universitária.

LISSAKERS, Karin. (1991). Banks, borrowers, and the establishment: a revisionist account of the international debt crisis. New York: Basic Books.

LOHR, Steve. (1988). "European Nations Assail Decision By U.S. to Deny a Visa for Arafat". The New York Times, November 28, Section A; Page 13, Column 1

LUBASCH, Arnold. (1988). "Judge rules P.L.O. can retain office". The New York Times, 30 de junho.

LYNE, Mona N., NIELSON, Daniel L., TIERNEY, Michael J. (2006). "Who delegates? Alternative models of delegation in development aid", in HAWKINS, Darren G., LAKE, David A., NIELSON, Daniel L., TIERNEY, Michael J. (eds.), Delegation and agency in international organizations. Cambridge: Cambridge University Press.

MACKAY-SMITH, Anne, GROVER, Stephen. (1982). "Gold soars to 11-month high on rumor that Argentina may repudiate its debt", The Wall Street Journal, 3 de setembro, p. 19.

MADRID, Raúl L. (1992). Overexposed: U.S. banks confront the Third World debt crisis. Boulder: Westview Press.

MANSFIELD, Edward D., MILNER, Helen V., ROSENDORFF, Peter. (2002). "Why Democracies Cooperate More: Electoral Control and International Trade Agreements". International Organization, Vol. 56, No. 3.

MANSFIELD, Edward D., PEVEHOUSE, Jon C. (2006). "Democratization and international organizations". International Organization, Vol. 60, No. 1.

MARTIN, Lisa L. (2000). Democratic commitments: legislatures and international cooperation. Princeton, NJ: Princeton University Press.

MAY, Donald. (1982). "September 6, 1982, Monday, AM cycle”. United Press International, 6 de setembro.

MAYER, Martin. (1987). “Another nonstarter”. American Banker, 9 de outubro.

MAYHEW, David. (1974). The Electoral Connection. New Haven: Yale University Press.

McCUBBINS, Mathew, SCHWARTZ, Thomas. (1984). "Congressional oversight overlooked: police patrol versus fire alarms". American Journal of Political Science, Vol. 28, No. 1.

McCUBBINS, Mathew, Noll, Roger, WEINGAST, Barry. (1987). "Administrative procedures as an instrument of political control". Journal of Law, Economics, and Organization, Vol. 3. 
McKELVEY, Richard. (1976). "Intransitivities in multidimensional voting models and some implications for agenda control". Journal of Economic Theory, Vol. 12, No. 3.

MILLER, Gary J. (2005). "The political evolution of principal-agent models". Annual Review of Political Science, Vol. 8.

MILLER, Gary J., MOE, Terry M. (1983). "Bureaucrats, legislators and the size of government". American Political Science Review, Vol. 77.

MILNER, Helen V. (1997). Interests, institutions and information: domestic politics and international relations. Princeton: Princeton University Press.

MOMANI, Bessma. (2004). "American politicization of the International Monetary Fund". Review of International Political Economy, Vol. 11, No. 5.

MOMANI, Bessma. (2005). "Recruiting and diversifying IMF technocrats". Global Society, Vol. 19, No. 2.

MOE, Terry M. (1987). "An assessment of the positive theory of "congressional dominance"”. Legislative Studies Quarterly, Vol. 12, No. 4.

MOMANI, Bessma. (2004). "American politicization of the International Monetary Fund". Review of International Political Economy, Vol. 11, No. 5.

MORAVCSIK, Andrew. (1994). "Why the European Union strengthens the state: domestic politics and international cooperation". Working Paper Series \#52. Center for European Studies, Harvard University.

MORAVCSIK, Andrew. (1998). The choice for Europe: social purpose and state power from Messina to Maastricht. Ithaca, New York: Cornell University Press.

MORAVCSIK, Andrew. (2000). "The origins of human rights regimes: democratic delegation in postwar Europe”. International Organization, Vol. 54, No. 2.

MORRIS, Bailey. (1985). "First America, then the world. Interview with James Baker, US Treasury Secretary". The Times, 15 de novembro.

MOSLEY, Paul, HARRIGAN, Jane, TOYE, John. (1991). Aid and power: the World Bank and policy-based lending. London: Routledge.

MOSSBERG, Walter S., TRUELL, Peter. (1989). "Bush to back efforts to cut world debt; internal debate continues on specifics”, The Wall Street Journal, 10 de março.

NAVARRETE, Jorge E. (1985). "Foreign policy and international financial negotiations: the external debt and the Cartagena Consensus". CEPAL Review, No. 27.

NEW YORK TIMES, The. (1988). “Conable urges aid by the U.S.”, 15 de junho.

NEW YORK TIMES, The. (2008a). "Oil Prices Pass Record Set in '80s, but Then Recede”. 8 de março. 
NEW YORK TIMES, The. (2008b). “Fed’s \$85 billion load rescues insurer”. 17 de setembro.

NEWSWEEK. (1982). "The right-wing revolt", 16 de agosto.

NIELSON, Daniel L., TIERNEY, Michael J. (2003). "Delegation to international organizations: agency theory and World Bank environmental reform”. International Organization, Vol. 57, No. 2.

OATLEY, Thomas, YACKEE, Jason. (2004). “American interests and IMF lending". International Politics, Vol. 41, pp. 415-429.

O'BRIEN, Philip. (1986). “The debt cannot be paid': Castro and the Latin American debt”. Bulletin of Latin American Research, Vol. 5, No. 1.

O'DONNELL, Guillermo. (1985). "External debt: why our governments don't do the obvious?" CEPAL Review, No. 27.

O’DONNELL, Guillermo. (1987). "Brazil's failure: what future for debtors' cartels?" Third World Quarterly, Vol. 9, No. 4.

OFFICE OF MANAGEMENT AND BUDGET, (2008). The budget for fiscal year 2009, historical tables. Washington, D.C.: U.S. Government Printing Office. Disponível em <http://www.whitehouse.gov/omb/budget/fy2009/pdf/hist.pdf>. Acesso em 16/07/2009.

OLSON, Mancur. (1999). A Lógica da Ação Coletiva: os Benefícios Públicos e uma Teoria dos Grupos Sociais. São Paulo: Editora da Universidade de São Paulo.

OSTERBERG, William M. e THOMSON, James B. (1999). "The Exchange Stabilization Fund: How It Works". Economic Commentary, Federal Reserve Bank of Cleveland, dezembro.

PALMER, Jay. (1983). “The debt-bomb threat”. Time, 10 de janeiro.

PAROLA, Alexandre Guido Lopes. (1991). Estudo das políticas oficiais norte-americanas para a crise do endividamento externo da América Latina: 1982 a 1990. Brasília: Dissertação de Mestrado defendida no Departamento de Economia da Universidade de Brasília.

PASTOR, Robert A. (1982). Congress and the politics of U.S. foreign economic policy, 19291976. Berkeley: University of California Press.

PAYER, Cheryl. (1986). "The World Bank: a new role in the debt crisis?" Third World Quarterly, Vol. 8, No. 2.

PEVEHOUSE, Jon C. (2002). "With a little help from my friends? Regional organizations and the consolidation of democracy". American Journal of Political Science, Vol. 46, No. 3.

PINE, Art. (1982a). "U.S. sounds out allies on creating \$25 billion fund", The Wall Street Journal, 26 de agosto, p. 25. 
PINE, Art. (1982b). "Lender's jitters: international bankers take steps to restore faith in the system", The Wall Street Journal, 15 de setembro, p. 1.

PLEASE, Stanley. (1984). "The World Bank: lending for structural adjustement". In FEINBERG, Richard E., KALLAB, Valeriana (eds.), Adjustment crisis in the Third World. New Brunswick: Transaction Books.

POLLACK, Mark A. (2006). "Delegation and discretion in the European Union", in HAWKINS, Darren G., LAKE, David A., NIELSON, Daniel L., TIERNEY, Michael J. (eds.), Delegation and agency in international organizations. Cambridge: Cambridge University Press.

PUTNAM, Robert D. (1988). "Diplomacy and domestic politics: the logic of two-level games". International Organization, Vol. 42, No. 3.

REISMAN, W. Michael. (1989). "The Arafat Visa Affair: Exceeding the Bounds of Host State Discretion”. The American Journal of International Law, Vol. 83, No. 3, Julho..

REZEK, José Francisco. (2002). Direito Internacional Público: curso elementar. São Paulo: Saraiva.

RIDING, Alan. (1987). "Brazil to suspend interest payment to foreign banks", The New York Times, 20 de fevereiro.

ROCHESTER, J. Martin. (1986). "The rise and fall of international organization as a field of study". International Organization, Vol. 40. No. 4.

RODGERS, Peter, e HUHNE, Christopher. (1988). "And in the red corner... the big boys tussle over world debt”, The Guardian, 29 de setembro.

ROETT, Riordan. (1985). "Latin America's Response to the Debt Crisis". Third World Quarterly, Vol. 7, No. 2.

ROETT, Riordan. (1989). “How the 'haves' manage the 'have-nots': Latin America and the debt crisis". In STALLINGS, Barbara, KAUFMAN, Robert, Debt and democracy in Latin America. Boulder: Westview Press.

ROGERS, David. (1992). “Congress approves budget measure for foreign aid”, The Wall Street Journal, 6 de outubro.

ROLAND, Gérard. (2002). "The political economy of transition". The Journal of Economic Perspectives, Vol. 16, No. 1.

ROMER, Thomas, ROSENTHAL, Howard. (1978). "Political resource allocation, controlled agendas and the status quo". Public Choice, Vol. 33, No. 4.

ROSS, Stephen A. (1973). "The economic theory of agency: the principal's problem". The American Economic Review, Vol. 63, No. 2. 
ROWE Jr, James L. (1982). "Citibank foreign activities cited", The Washington Post, 14 de setembro, p. D7.

ROWEN, Hobart. (1980). "McNamara to step down at World Bank next year", The Washington Post, 10 de junho, p. A10.

ROWEN, Hobart. (1981a). "McNamar wants to reduce U.S. funds for multilateral development Banks", The Washington Post, 12 de março, p. D1.

ROWEN, Hobart. (1981b). "Goodbye to McNamara's bank", The Washington Post, 25 de junho, p. A23.

ROWEN, Hobart. (1981c). "Stress free enterprise, Reagan tells poor lands", The Washington Post, 30 de setembro, p.A3.

ROWEN, Hobart. (1982a). "Study Questions Whether IMF Can Meet Needs", The Washington Post, 25 de agosto, p. D7.

ROWEN, Hobart. (1982b). "Report on IMF Funds Challenged", The Washington Post, 26 de agosto, p. B1.

ROWEN, Hobart. (1982c). "Bank Ministers Meeting Amid World Trauma; Deepening Recession and U.S.-European Rift Overhang at Toronto". The Washington Post, 29 de agosto, p. F1.

ROWEN, Hobart. (1982d). "IMF board shelves U.S. Proposal for a 'crisis fund", The Washington Post, 4 de setembro, p. A17.

ROWEN, Hobart. (1982e). "Poor Nations Fire Warning at IMF Talks", The Washington Post, 4 de setembro, p. C1.

ROWEN, Hobart. (1982f). "Lost opportunity at Toronto", The Washington Post, 9 de setembro, p. A25.

ROWEN, Hobart. (1982g). "U.S. backs expanded IMF, Bank lending”, The Washington Post, 9 de setembro, p. D1.

ROWEN, Hobart. (1982h). "IMF, Bank meetings end on uneasy note", The Washington Post, 10 de setembro, p. D8.

ROWEN, Hobart. (1982i). “Agreement set on IMF funding; U.S. backs major infusion for loans for Third World", The Washington Post, 21 de novembro, p. H1.

ROWEN, Hobart. (1983). "Study faults plans for consolidating Third World debt", The Washington Post, 19 de abril, p. F1.

ROWEN, Hobart. (1984). "Rich nations should adopt new strategy on global debt", The Washington Post, 29 de julho, p. G1. 
ROWEN, Hobart. (1985a). "Five nations' finance ministers to meet today", The Washington Post, 22 de setembro, p. A1.

ROWEN, Hobart. (1985b). "Clausen saga comes to an end", The Washington Post, 13 de outubro, p. D1.

ROWEN, Hobart. (1986). "Baker rejects 'quick fix' on world debts", The Washington Post, 5 de dezembro, p. G1.

ROWEN, Hobart. (1988a). "White House opposes IMF funding plan”, The Washington Post, 21 de janeiro.

ROWEN, Hobart. (1988b). "Baker pushes for World Bank funds; Treasury Secretary opposes delays on money for use in debt crisis", The Washington Post, 31 de março.

ROWEN, Hobart. (1988c). "Baker criticizes House leadership for rejecting World Bank proposal", The Washington Post, 7 de maio.

ROWEN, Hobart. (1988d). "Trading barbs over the World Bank", The Washington Post, 19 de maio.

ROWEN, Hobart. (1988e). "Baker urges U.S. to end holdout at the World Bank", The Washington Post, 16 de junho.

RUGGIE, John Gerard. (1993). "Multilateralism: the anatomy of an institution”. In RUGGIE, John Gerard (ed.), Multilateralism matters: the theory and praxis of an institutional form. New York: Columbia University Press.

SANFORD, Jonathan E., WEISS, Martin A. (2004). "International Monetary Fund: organization, functions, and role in the international economy". CRS Report for Congress, April 22.

SCHAEFER, Brett D. (2001). "Stop subsidizing terrorism”. The Heritage Foundation Backgrounder, October 4.

SCHICK, Allen. (1975). "The battle of the budget". Proceedings of the Academy of Political Science, Vol. 32, No. 1.

SCHLESINGER JR., Arthur M. (1973). The Imperial Presidency. Boston: Houghton Mifflin.

SCHWARTZ, Anna T. (1997). "From obscurity to notoriety: a biography of the Exchange Stabilization Fund”. Journal of Money, Credit and Banking, Vol. 29, No. 2, May.

SEABERRY, Jane. (1985). "Trade deficit second highest ever in June", The Washington Post, 31 de julho, p. A1.

SEBENIUS, James K. (1992). "Challenging conventional explanations of international cooperation: negotiation analysis and the case of epistemic communities". International Organization, Vol. 46, No. 1. 
SEIB, Gerald F., HARWOOD, John. (1992). "Bush, allies pledge \$ 24 billion to Russia", The Wall Street Journal, 2 de abril.

SEIB, Gerald F., MOSSBERG, Walter S. (1989). "Bush fully backs Brady debt plan for Third World", The Wall Street Journal, 15 de março.

SHEPSLE, Kenneth. (1978). The giant jigsaw puzzle: democratic committee assignments in the modern House. Chicago: University of Chicago Press.

SHEPSLE, Kenneth. (1979). "Institutional arrangements and equilibrium in multidimensional voting models". American Journal of Political Science, Vol. 23, No. 1.

SHEPSLE, Kenneth, BONCHEK, Mark. (1997). Analysing politics: rationality, behavior, and institutions. New York: W. W. Norton.

SHEPSLE, Kenneth, WEINGAST, Barry. (1984). "Uncovered sets and sophisticated voting outcomes with implications for agenda institutions". American Journal of Political Science, Vol. 28, No. 1.

SHEPSLE, Kenneth, WEINGAST, Barry. (1987). "The institutional foundations of committee power". American Political Science Review, Vol. 81, No. 1.

SHOCH, James. (1998). "Party politics and international economic activism: the ReaganBush years". Political Science Quarterly, Vol. 113, No. 1.

SIMON, William E. (1983), "Cut off the international loan lushes". Wall Street Journal, 6 de abril.

SINCLAIR, Barbara. (1985). "Agenda control and policy success: Ronald Reagan and the $97^{\text {th }}$ House". Legislative Studies Quarterly, Vol. 10, No. 3, August.

SMITH, Fred L. (1984). “The politics of IMF lending”, Cato Journal, Vol. 4, No. 1.

SPENCE, Michael, ZECKHAUSER, Richard. (1971). "Insurance, information and individual action". The American Economic Review, Vol. 61, No. 2.

STOCKMAN, David A. (1986). The triumph of politics: the inside story of the Reagan Revolution. New York: Avon Books. Paperback.

STRANGE, Susan. (1974). "IMF: monetary managers". In COX, Robert W., JACOBSON, Harold K., The anatomy of influence: decision making in International Organization, New Haven: Yale University Press.

STRANGE, Susan. (1982). “Cave! hic dragones: a critique of regime analysis". International Organization, Vol. 36, No. 2.

STREETER, Sandy. (2008). "The Congressional appropriations process: an introduction". CRS Report for Congress 97-684. December 2, (2008). 
SUNDQUIST, James L. (1981). The Decline and Resurgence of Congress. Washington, D.C.: Brookings Institution.

SWEDBERG, Richard. (1986). "The doctrine of economic neutrality of the IMF and the World Bank". Journal of Peace Research, Vol. 23, No. 4.

THACKER, Strom C. (1999). "The high politics of IMF lending”. World Politics, Vol. 52, No. 1.

TIMES,THE. (1986). "New attacks ob Baker debt plan", $1^{\circ}$ de dezembro.

TORDAY, Peter. (1988). "IMF head accuses Banks of hurting debt crisis strategy", The Wall Street Journal, 11 de maio, p. 1.

TRUELL, Peter. (1987a). "Bankers view Brazil debt plan as innaceptable", The Wall Street Journal, 4 de setembro.

TRUELL, Peter. (1987b). "Brazilian official plans to meet counterparts", The Wall Street Journal, 8 de setembro.

TRUELL, Peter. (1987c). "Baker outlines proposals to aid debt strategy", The Wall Street Journal, $1^{\underline{0}}$ de outubro.

TRUELL, Peter. (1988a). "Treasury, banks close to accord on Brazil debt - pact could help clear way to debt restructuring and provide new loans", The Wall Street Journal, 12 de maio.

TRUELL, Peter. (1988b). "A year later, Latin debt crisis deepens — if loans dry up, so will interest payments", The Wall Street Journal, 19 de maio.

TRUELL, Peter. (1988c). "Argentina skirts IMF with reform plan as Fund's director quarrels with U.S.”, The Wall Street Journal, 26 de setembro.

TULLOCK, Gordon, BUCHANAN, James M. (1962). The calculus of consent. Ann Arbor: University of Michigan Press.

UNAL,Haluk, KUNT, Asli, LEUNG, Kwok-Wai. (1993). “The Brady Plan, 1989 Mexican debt-reduction agreement, and bank stock returns in United States and Japan”. Journal of Money, Credit and Banking, Vol. 25, No. 3.

U.S. CONGRESS (1984). International Debt: Hearing before the Joint Economic Committee of the United States Congress. S. Hrg. 98-838. $98^{\text {th }}$ Congress. Mar. 28, 1984.

U.S. CONGRESS (1985). Impact of the Debt Crisis on the U.S. Economy: Hearings before the Joint Economic Committee of the United States Congress. S. Hrg. 99-501. $99^{\text {th }}$ Congress. June 17, 21, 24, 1985.

U.S. CONGRESS (1986a). Managing the debt problem: Hearings before the Subcommittee on Economic Goals and Intergovernmental Policy of the Joint Economic Committee of the Congress of the United States. S. Hrg. 99-647. $99^{\text {th }}$ Congress. January 23, 1986. 
U.S. CONGRESS (1986b). Alternative policies for managing the international debt crisis: Hearing before the Joint Economic Committee of the Congress of the United States. S. Hrg. 99-1097. $99^{\text {th }}$ Congress. June 24, 1986.

U.S. CONGRESS (1987). Economic Development in Latin America and the debt problem: Selected essays prepared for the use of the Subcommittee on Economic Growth, Trade and Taxes of the Joint Economic Committee. S. Prt. 100-54. $100^{\text {th }}$ Congress. October 29, 1987.

U.S. HOUSE (1983a). International Financial Markets and Related Problems: Hearing before the Committee on Banking, Finance, and Urban Affairs of the House of Representatives. Serial No. 98-13. $98^{\text {th }}$ Congress. Feb. 2, 8, 9, 1983.

U.S. HOUSE (1983b). International Monetary Fund quota increase: Hearing before the Task Force on International Finance and Trade of the Committee on the Budget of the House of Representatives. Serial TF9-2. $98^{\text {th }}$ Congress. March 7, 1983.

U.S. HOUSE (1983c). To increase the U.S. quota in the International Monetary Fund and related matters: Hearings before the Subcommittee on International Trade, Investment and Monetary Policy of the Committee on Banking, Finance and Urban Affairs of the House of Representatives. Serial No. 98-17. $98^{\text {th }}$ Congress. April 7, 26, 27, 28, and May 3, 1983.

U.S. HOUSE (1984a). Congress and Foreign Policy 1983. Committee Print. Committee on Foreign Affairs of the House of Representatives. Serial H382-19.

U.S. HOUSE (1984b). Compilation of the Domestic Housing and International Recovery and Financial Stability Act of 1983. Committee Print 98-9. $98^{\text {th }}$ Congress, September 1984.

U.S. HOUSE (1984c). U.S. Trade Deficit: Hearings before the Subcommittee on Trade of the Committee on Ways and Means of the House of Representatives. Serial No. 98-73. $98^{\text {th }}$ Congress. March 28, 29, April 5, 10, 12, 25, 1984.

U.S. HOUSE (1985a). Role of Multilateral Development Institutions in Global Economy: Hearings before the Subcommittee on International Development Institutions and Finance of the Committee on Banking, Finance, and Urban Affairs of the House of Representatives. Serial No. 99-29. $99^{\text {th }}$ Congress. July 30, 1985.

U.S. HOUSE (1985b). Mandate for Development: The Future of the World Bank: Hearings before the Subcommittee on International Development Institutions and Finance of the Committee on Banking, Finance, and Urban Affairs of the House of Representatives. Serial No. 99-42. 99 ${ }^{\text {th }}$ Congress. September 5, 1985.

U.S. HOUSE (1985c). U.S. proposals on international debt crisis: Hearings before the Committee on Banking, Finance and Urban Affairs of the House of Representatives. Serial No. 99-39. $99^{\text {th }}$ Congress. October 22, 1985.

U.S. HOUSE (1987a). Banking Committee provisions of the Trade Bill: Hearings before the Subcommittee on International Finance, Trade and Monetary Policy of the Committee 
on Banking, Finance and Urban Affairs of the House of Representatives. Serial No. 100-6. 100 ${ }^{\text {th }}$ Congress. March 3, 4, and 10, 1987.

U.S. HOUSE (1987b). Third World debt: Hearings before the Subcommittee on International Development Institutions and Finance of the Committee on Banking, Finance and Urban Affairs of the House of Representatives. Serial No. 100-7. 100 ${ }^{\text {th }}$ Congress. March 3 and $4,1987$.

U.S. HOUSE (1987c). Brazilian debt crisis: Hearing before the Subcommittee on International Finance, Trade, and Monetary Policy of the Committee on Banking, Finance and Urban Affairs of the House of Representatives. Serial No. 100-15. 100 ${ }^{\text {th }}$ Congress. April 23, 1987.

U.S. HOUSE (1988). General capital increase for the World Bank: Hearing before the Committee on Banking, Finance and Urban Affairs of the House of Representatives. Serial No. 100-72. $100^{\text {th }}$ Congress. June 15, 1988.

U.S. HOUSE (1989a). International economic issues, and their impact on the U.S. financial system: Hearings before the Committee on Banking, Finance and Urban Affairs of the House of Representatives. Serial No. 101-1. $101^{\text {st }}$ Congress. January 4 and 5, 1989.

U.S. HOUSE (1989b). Third World debt-Reports and the Brady Plan: Hearing before the Subcommittee on International Development, Finance, Trade and Monetary Policy of the Committee on Banking, Finance and Urban Affairs of the House of Representatives. Serial No. 101-14. $101^{\text {st }}$ Congress. March 16, 1989.

U.S. HOUSE (1989c). Third World debt: public reaction to the Brady Plan: Hearing before the Subcommittee on International Development, Finance, Trade and Monetary Policy of the Committee on Banking, Finance and Urban Affairs of the House of Representatives. Serial No. 101-19. $101^{\text {st }}$ Congress. April 5, 1989.

U.S. HOUSE (1989d). The international debt crisis: a review of the Brady Plan: Hearing before the Subcommittee on International Economic Policy and Trade of the Committee on Foreign Affairs of the House of Representatives. Serial No. H381-2. $101^{\text {st }}$ Congress. April 19, 1989.

U.S. SENATE (1982). World debt situation: Hearing before the Subcommittee on International Economic Policy of the Committee on Foreign Relations of the United States Senate. S 381-14. $97^{\text {th }}$ Congress. September 27, 1982.

U.S. SENATE (1983a). International debt: Hearings before the Subcommittee on International Finance and Monetary Policy of the Committee on Banking, Housing, and Urban Affairs of the United States Senate. S. Hrg. 98-81. $98^{\text {th }}$ Congress. February 14, 15 and 17, 1983.

U.S. SENATE (1983b). International Monetary Fund Quota Increase: Hearings before a Subcommittee of the Committee on Appropriations of the United States Senate. S. Hrg. 98-402. $98^{\text {th }}$ Congress. May 17, 18, 1983. 
U.S. SENATE (1984). The Argentinian debt: Hearing before the Subcommittee on International Finance and Monetary Policy of the Committee on Banking, Housing and Urban Affairs of the United States Senate. S. Hrg. 98-782. $98^{\text {th }}$ Congress. May 3, 1984.

U.S. SENATE (1985). U.S. economic growth and the Third World Debt: Hearings before the Subcommittee on International Economic Policy, Oceans, and Environment of the Committee on Foreign Relations of the U.S. Senate. S. Hrg. 99-455. $99^{\text {th }}$ Congress. Oct. $9,10,1985$.

U.S. SENATE (1986). Economic summit, Latin debt and the Baker Plan: Hearing before the Committee on Foreign Relations of the United States Senate. S. Hrg. 99-889. $99^{\text {th }}$ Congress. May 20, 1986.

U.S. SENATE (1987a). Impact of the Latin American debt crisis on the United States: Hearing before the Subcommittee on International Debt of the Committee on Finance of the United States Senate. S. Hrg. 100-33. 100 ${ }^{\text {th }}$ Congress. March 9, 1987.

U.S. SENATE (1987b). Exchange rates and the Third World debt: Hearings before the Subcommittee on International Finance and Monetary Policy of the Committee on Banking, Housing, and Urban Affairs of the United States Senate. S. Hrg. 100-141. $100^{\text {th }}$ Congress. March 26, April 1, 2, and 7, 1987.

U.S. SENATE (1987c). Third World debt problem: Hearing before the Subcommittee on International Debt of the Committee on Finance of the United States Senate. S. Hrg. 100-120. 100 ${ }^{\text {th }}$ Congress. April 6, 1987.

U.S. SENATE (1988). New Directions for Dealing with the International Debt Problem: Hearings before the Subcommittee on International Finance and Monetary Policy of the Committee on Banking, Housing, and Urban Affairs of the U.S. Senate. S. Hrg. 100856. $100^{\text {th }}$ Congress. Aug. 2, 4, 1988.

U.S. SENATE (1990a). Implementation of the Brady Plan: Hearing before the Subcommittee on International Debt of the Committee on Finance of the United States Senate. S. Hrg. 101-801. 101 ${ }^{\text {st }}$ Congress. March 2, 1990.

U.S. SENATE (1990b). Third World Debt Strategy: Hearing before the Committee on Banking, Housing, and Urban Affairs of the United States Senate. S. Hrg. 101-714. $101^{\text {st }}$ Congress, March 21, 1990.

VAN HOUTVEN, Leo. (2002). Governance of the IMF: decision making, institutional oversight, transparency, and accountability. IMF Pamphlet Series No. 52. Washington, D.C.: IMF.

VEJA. (1982a). “O alarma da concordata", 8 de setembro, pp. 120-131.

VEJA. (1982b). “O preço do socorro”, 8 de dezembro, pp. 32-39.

VEJA. (1982c). “Os 100 dias negros”, 15 de dezembro, pp. 142-147.

VEJA. (1985). "Sinais de fumaça", 16 de outubro, pp. 110-111. 
VEJA. (1987a). "Sarney espeta a conta”, 25 de fevereiro, pp. 20-27.

VEJA. (1987b). “Missão impossível”, 15 de abril, pp. 26-29.

VEJA. (1987c). "Fiasco em Washington”, 16 de setembro, p. 18-22.

VEJA. (1988a). “A volta do realismo”, 20 de janeiro, pp. 76-77.

VEJA. (1988b). "De volta aos trilhos”, 10 de fevereiro, pp. 68-70.

VEJA. (1988c). “Uma volta à política da realidade”, 25 de maio, pp. 96-101.

VEJA. (1988d). “Crédito na praça”, 29 de junho, pp. 102-105.

VEJA. (1989). “A virada nos ventos da dívida externa”, 15 de março, pp. 82-88.

VELlOSO, João Paulo dos Reis. (1986). O último trem para Paris. Rio de Janeiro: Nova Fronteira.

VOLCKER, Paul, GYOHTEN, Toyoo. (1992). Changing fortunes: the world's money and the threat to American leadership. New York: Times Books.

VREELAND, James R. (2004). "The international and domestic politics of IMF programs". Paper apresentado na conferência The Fund's role in emerging markets, organizada pelo Reinventing Bretton Woods Committee e pelo World Economic Forum em 18 e 19 de novembro de 2004.

WALL STREET JOURNAL, THE. (1982). “Gold increases $\$ 11.40$ to $\$ 386.5$ an ounce as lending rates fall”, 23 de agosto, p. 20.

WALL STREET JOURNAL, THE. (1988). "Review \& Outlook: skip the guarantees", 28 de abril.

WANNISKI, Jude. (1980). “A supply-side foreign policy”. American Expectator, Dezembro. Disponível em <http://www.polyconomics.com/essays/esy-801203.htm>. Acesso em 08/10/2009.

WASHINGTON POST, THE. (1987). "Brazil and the bankers", 25 de fevereiro, p. A22.

WASHINGTON POST, THE. (1988a). “Banking on America’s word”, 24 de maio.

WASHINGTON POST, THE. (1988b). "They missed the boat”, 26 de maio.

WASHINGTON POST, THE. (1989). "Mexico and the debts”, 30 de março, p. A22.

WELLONS, Philip A. (1987). Passing the buck: banks, governments and Third World debt. Boston: Harvard Business School Press.

WERTMAN, Patricia A. (1987a). "The international debt problem: options for solution". In CONGRESSIONAL RESEARCH SERVICE, Economic development in Latin America and the debt problem. Washington: US Government Printing Office. 
WERTMAN, Patricia A. (1987b). "U.S. bank exposure in the 'Baker Plan' fifteen countries". CRS Report for Congress 87-299E. Washington: Congressional Research Service.

WERTMAN, Patricia A. (1998). “The International Monetary Fund's (IMF) proposed quota increase: issues for Congress". CRS Report for Congress 98-56, 16 de janeiro.

WERTMAN, Patricia A., HAIRSTON, Pamela. (1998). "The IMF and 'voice and vote' amendments: a compilation”. CRS Report for Congress, 98-391, 16 de abril.

WHITEHEAD, Laurence. (1989). "Latin american debt: an international bargaining perspective". Estudos Avançados, Vol. 3, No. 7.

WIJNBERGEN, Sweder van. (1991). "Mexico and the Brady Plan". Economic Policy, Vol. 6, No. 12, abril.

WILDAVSKY, Aaron 1966. "The Two Presidencies", republicado em BAILEY JR., Harry A., SHAFRITZ, Jay M. (eds.), The American Presidency: Historical and Contemporary Perspectives. Chicago: Dorsey Press.

WOODS, Ngaire. (2002). “The United States and the international financial institutions: power and influence within the World Bank and the IMF". In FOOT, Rosemary, MacFARLANE, S. Neil, MASTANDUNO, Michael, US hegemony and international organizations, Oxford: Oxford University Press. 


\section{Anexo: originais em inglês das principais citações}

i. "A loan or credit to a foreign entity or government of a foreign country may be made for more than 6 months in a 12- month period only if the President gives Congress a written statement that unique or emergency circumstances require the loan or credit be for more than 6 months".

ii. "It was clear to all that this was a medium- to long-term arrangement, that Brazil would continue to borrow and that the market would supply the money for debt servicing. Brazil didn't pay a penny out of its own pocket until 1982. The money was always provided by the market. Everyone assumed this would continue."

iii. "Access to private sources of balance-of-payments finance may [...] in some cases permit countries to postpone the adoption of adequate domestic stabilization measures. This can exacerbate the problem of correcting payments imbalances, and can lead to adjustments that are politically and socially disruptive when the introduction of stabilization measures becomes unavoidable".

iv. "Argentina is the most imminent of those, I think. It's a different situation in many respects, but just in terms of our own posture - and it's worth discussing briefly — we have no swap agreement with Argentina. We have always refused to extend [the swap network]: this [swap line] with Mexico is somewhat of a special deal with a neighbor. [...] What the U.S. government would want to do in the case of Argentina is something else again. I imagine that if Argentina gets into this kind of jam, the question is going to be raised. But we do have a distinction in what we have done in the past and in our general attitude between Mexico and Argentina, just to take the next most imminent [problem economy].Brazil, Venezuela, and others could be involved, too, but I think Argentina is the most imminent. Now, their debt is a lot smaller, of course."

v. "I think the fundamental point is the one you just made: none of this is going to work unless there is a good [economic] adjustment program. And it's going to have to be a very draconian adjustment program. [...] I'm not sure that anybody can judge how much the country can take. A country can have a fine-looking draconian adjustment program but if the country goes up in revolution, it will be unsuccessful. [...] But that has to be the fundamental backstop of any credit. We have labored long over the collateral issue and there aren't any terribly satisfactory answers because Mexico doesn't have that much collateral. But there are answers, satisfactory or not. The idea of this is that our present swap will remain secured, if that's the word, by a Fund agreement that doesn't exist yet. But if it does come into existence, our swap will have first claim on it. This second loan - and the proposal is that this would be a separate swap will be secured along side the BIS arrangement with the remainder of the Fund drawings as they are available over time. I guess we have the gold [collateral] by implication. They are willing to pledge $\$ 250$ million in gold, which doesn't go very far, but there it is. And by some assignment yet to be worked out, oil revenues are an ultimate backstop if nothing else works."

vi. "If it really worked out well, we would get paid out of private financing [...] The banks would put up more loans and Mexico would repay us. [...] But we may be dreaming, too." 
vii. "VICE CHAIRMAN SOLOMON. I would say that there would be very strong support from the Congress. The thought of economic chaos in Mexico, with all those millions of people trying to pour in over the border, is just so upsetting to members of the Congress that I think there would be widespread support.

MR. MARTIN. The month after they pass the first big change in the immigration statute in 30 years or whatever it is!

MR. PARTEE. Well, of course, there's likely to be enough economic hardship in Mexico that there will be flight across the border anyhow.

CHAIRMAN VOLCKER. Yes, we're going to get it anyway.

VICE CHAIRMAN SOLOMON. But there is a perceptible difference between austerity programs and actual collapse."

viii. "When one looks elsewhere in Latin America, at the other end of the continent we have Argentina, which is basically unable to finance its needs in the markets and is in substantial arrears on its indebtedness. The financial officials there are willing to go to the International Monetary Fund. Fund negotiations are starting with rather an unknown situation as to whether Argentina has a government of sufficient strength to sign a reasonable Fund agreement even if they want to. [...] That is a situation that in some sense doesn't look unmanageable economically, but there is a question as to how manageable it is politically. When one goes up in that continent, there is Ecuador, which may be facing an inability to service its debt in a matter of weeks. We have Chile, which as nearly as I can see is unable to finance itself at the moment and is rapidly depleting its reserves; and at the rate of depletion of reserves one can perhaps measure their debt difficulties in a matter of months, if not weeks. We have Bolivia, which has had chronic problems for years and is no better: it is basically in default. Costa Rica is in the same position. Peru is not much different. And then we come to the strong countries in the continent like Brazil! That is another $\$ 80$ billion debtor, which in my eyes has undertaken a strong adjustment program for the past 18 months, has had a recession, has had monetary restraint, and has attempted to get its budget in shape. Their balance of payments deficit is as big today as it was when they started the program, reflecting in considerable part the sourness of the world economy. Then of course we have Venezuela, the premier country in terms of financial strength of the continent. It is a relatively small country with big oil reserves, but it also is apparently unable to finance itself freely in the market currently [despite] more substantial reserves [...]. Those countries have a collection of debt of [...] about $\$ 300$ billion [...] of which a sizable fraction is owed to American banks. But every big bank around the world is more or less equally committed. All of these countries are dependent upon sustained borrowing to maintain a semblance of equilibrium during this period: indeed, all of them are dependent upon sustained borrowing simply to keep the loans that are now on the books in a semblance of good order."

ix. "All of which brings me to the banking system. We have had some rather well-known problems with respect to individual institutions, stemming largely from domestic concerns in the United States. Those particular institutions have had financing difficulties in the market for some time. They are basically unable or unwilling to sell any substantial amount of domestic CDs and are having their lines from other banks cut back in the day-to-day market. There is concern, obviously, more generally about banks with large external exposure. And when we talk about banks with large external exposures there are no exceptions among the major American banks or among a good many of the regional banks. [...] [It] is quite apparent that the Eurodollar market is in a state of some confusion and concern. One can see that specifically in the fact that the Eurodollar rates have a margin over domestic rates that is not explicable by normal arbitrage calculations between the two rates. [...] [There] is a sense of a contraction in credit." 
x. "No central bank wants to touch these situations in the sense of a traditional central banking operation. They all would take the same attitude that we probably would take: It's a governmental problem. And some of them have institutions to do it and some don't. In virtually every case the central bank has more flexibility in the short run than the government; some governments have none. Some central banks may not have any. We have this kind of problem, of course. The U.S. government itself is like dealing with four different countries! But you multiply that and the difficulty becomes geometric."

xi. "When we agree to add to the IMF till, we transfer our resources to a supranational organization that we do not control, to be disbursed by an international bureaucracy. The multilateral approach has the advantage of dragging others into the aid process, and the U. S. isn't left alone holding the bag, but the disadvantages are great. It is hard to hold multilateral middlemen accountable, and we get in the habit of subsidizing every socialist government in the Third World."

xii. "Passing foreign aid through an international bureaucracy reduces the control of influence of the donor countries. The ultimate result is to divorce foreign aid from the policy interest of the United States and the NATO alliance. When we let the IMF disburse our money for us, we cannot extract political and strategic benefits from the recipient countries on a quid pro quo basis."

xiii. "I think that the process of going to the Congresses and Parliaments of the world for the quota increases [...] may take a very long time. I would urge your committee, Mr. Chairman, to consider the possibility of another and perhaps quicker method.

That would be to alter current IMF policies, and this can be done at the board of directors level with the participation of the executive director from the United States, to alter current IMF policies to permit special programs not tied to amounts of IMF quotas. These would be specific safety net type activities.

[...] I would suggest the Monetary Fund be authorized for the first time to turn to the private capital markets of the world [...]. [This policy] does not involve going back to the countries themselves and obtaining new authorizations.

xiv. "All our newspapers have printed about the emergency aid that we, through the Federal Reserve Board, have given Mexico. Well, this is inaccurate. We have not given Mexico anything. The money we provided was to bail out American banks. It was relief, bailout for the American banks which this Administration does not draw the line on. It draws the line on American corporations. They do not want any bailouts there. They do not want bailouts for the small business, but if it is a bank, why, $\$ 1$ billion without questions overnight was what they did in order to save such banks as Chase Manhattan and the Hanover Manufacturers Trust [...]. The most conservative elements by definition are those that have been the unwise investors and spenders and speculators through sheer greed. Greed is what is getting us under."

$\mathrm{xv}$. "The tragedy of the present monetary chaos in Mexico is the massive harm what it will cause to the people of Mexico. [...] The U.S. has a responsability in this situation, but my concern is that it will be little more than a temporary bailout - one that will appear to help Wall Street bankers more than Mexican citizens."

xvi. "I have little sympathy for bankers who have made billions of dollars of loans to Mexico in spite of, and with full knowledge of, economic policies that inexorably led to this crisis. I think that they should bear the brunt of their losses — not the American taxpayer. [...] If we follow past practices of U.S. financial assistance, [...] Mexico will be provided with a temporary bailout in spite of the likelihood that a repeat of the current financial debacle is just around the 
next corner. [...] That is why the resolution I put forth today is important. It may provide a basis for taking actions that would otherwise be politically unpalatable. [...] If these actions are not taken [...], then any assistance provided directly oer indirectly to the United States is a waste of taxpayers money, and we might as well just use it to build a 40 -foot wall along our southern border."

xvii. "Liberal bankers and diplomats should not be given the opportunity to solve the situation taking into account only the financial point of view, since they could help to build a political problem south of the border of incalculable gravity."

xviii. "The situation today, while serious, is manageable, appears transitory and, to a degree, is selfcorrecting".

xix. "We thought [the IMF] would approve the Mexican program, and put up some money. We thought then we'd have a second shot decision as to whether we'd go along or not. When de Larosière said the whole IMF deal was conditional on the banks putting up $\$ 5$ billion in new money, we were shocked. When he said we had to have the money by December 15, we were appalled."

xx. "In such cases, where new loans facilitate the adjustment process and enable a country to strengthen its economy and service its international debt in an orderly manner, new credits should not be subject to supervisory criticism".

xxi. "Passage of the IMF quota increase makes a joke of any attempt to control spending domestically".

xxii. "It's very difficult for me, at least, to understand why the banks should have to be paid a bonus for participating in a rescue package that is as much to their benefit, and at this point, even more to their benefit, than to the debtor countries. Protecting the banks against catastrophic loan losses does not necessarily require saving them from all loss of income in loans that are turned sour. [...] Congress [...] should insist that [...] the banks be forced to share in the costs of the restructuring by reducing their interest income on new and rescheduled loans."

xxiii. "If one thinks back in terms of the origin of the International Monetary Fund, the World Bank, and the United Nations in the postwar years, we remember that these institutions were founded on a strong moral base to try to ensure the fulfillment of human rights, the fulfillment of political democracy, as well as promoting economic growth in the postwar world."

xxiv. "It is also apparent that the United States did little to [...] determine how apartheid contributes to the economic problems which beset South Africa and what adjustments could be made.

How ironic it is $[\ldots]$ that the institution which tells borrowing countries, such as Egypt, to raise food prices or devalue its currency, as in the case of Sudan, or to cut services and subsidies, as in the case of Jamaica, remains silent in its structural adjustment programs with South Africa

xxv. "This bill is not perfect in any regard - either for housing or for the IMF. And it would be better if they could come up separately. But in these peculiar circumstances, this bill has to be together [...] to make the housing part veto proof. [...] Vote this down today and you will not have another IMF bill, and there will not be another housing bill."

xxvi. "The process we are being forced to follow here today is the strongest proof that the American people do not support the bailout of the banks and their bad loans".

xxvii. "If the American people supported this [...] policy [...], this legislation would have been passed early last summer". 
xxviii. "It appears to me that the bankers, because of the clubbiness of their industry and the fear everyone has that their institutions will collapse, got their relief, but that farms and factories in the United States had to go the extra mile in loss of sales and production, and the loss of employment."

xxix. "No doubt there is growing sensitivity in the Congress to the impact of the global economy on our own economic well-being. Rising imports, poor U.S. export performance, and the uncompetitive dollar are all topics of concern and focus.

Oddly enough, however, the domestic economic problems associated with the Latin det crisis have been largely ignored. Japan has become the symbol of all of our trade problems and frustrations. [...] But our trade problems with Latin America, in many respects, parallel the problems we face with Japan. They certainly do so in overall magnitude. [...] In 1980, our surplus [with the region] was $\$ 4.8$ billion. That has deteriorated to a $\$ 15.7$ billion deficit last year and is likely to get worse."

xxx. "But as [Baker] thought about it, he no more than I was able to devise a way to force limited losses on the banks while expecting them to advance new money to support their borrowers' return to health. Nor did he see any promise in the more grandiose approaches that were being argued by some in the Congress [...]. But there was no escaping the sense of fatigue and frustration, and the more important fact that growth and development were languishing. If we didn't like the more grandiose plans, we couldn't beat something with nothing. So we put our heads together."

xxxi. "What is likely to happen is that the IMF will negotiate a program. That exercise will determine what the financing requirements are for that country. And it will attempt to design with the country how that gap is going to be financed. In other words, how much of it will come from the World Bank, how much of it will come from IMF drawdowns, how much will come from the Inter-American Development Bank, and how much will come from commercial banks."

xxxii. "Both [Senator Phil] Gramm and I believed that the organs of international aid and so-called Third World development - the UN, the multilateral banks, and the U.S. Agency of International Development — were infested with socialist error. The international aid bureaucracy was turning Third World countries into quagmires of self-imposed inefficiency and burying them beneath mountainous external debt they would never be able to pay."

xxxiii. "Will the administration be asking the Congress' help in carrying out its plan to actively involve itself in the international debt crisis? Will the proposals contained in the "Program for Sustained Growth" require the authorization and appropriation of additional U.S. funding particularly for the World Bank, if not also the IMF?

If so, I and many others must be convinced of the need.

Mr. Secretary, you were at the White House in 1983 when we were able to pass the IMF funding bill by a mere six votes. [...] To refresh your memory, many Members of Congress could not understand - and still do not — how an austerity program imposed by the IMF on lesser developed countries could increase U.S. exports to these countries. [...]

Mr. Secretary, many Members of Congress, and many both in and out of the banking community, labeled the last IMF bill [...] a bailout bill for the big banks."

xxxiv. "Before I go any further, let me state that I oppose any further contribution to the World Bank or IMF by the U.S. Goverment.

At a time when the United States is running record deficits and the national debt is spilling over $\$ 2$ trillion, how can we hand over \$2 billion to the World Bank? How can the administration 
advocate a balanced budget by 1991 and scream about too much spending when it wants to give $\$ 2$ billion to the World Bank?

And it should be great news to hardpressed farmers who have been told by the administration that it won't bail them out, that in the last 4 years, the World Bank has had a 400 -percent increase in loans to Communist countries. [...]

Do U.S. funds really end up being used for the intended purpose or are they just another bailout of the big U.S. banks whose loans to other countries are in default? We give Costa Rica \$200 million a year in foreign aid and what happens to the money? Here is what the President of the country's central bank says happens to the money. "We are recycling money from the U.S. Government and paying it out to U.S. banks." [...]

There is one group in this country that is vitally concerned about giving away money to foreign countries who thumb their noses at the United States. That group is called taxpayers."

xxxv. "Today, the Subcommittee on Economic Goals and Intergovernmental Policy of the Joint Economic Committee will examine the implementation of the administration's international debt initiative unveiled by Secretary Baker last October in Seul. [...]

The initiatives announced by Secretary Baker in Seoul last October constitute an important departure in policy for the administration in terms of managing the debt problem."

xxxvi. "It was clear from the outset that the third world debt problem posed a serious, potentially catastrophic, threat to the stability of the international financial system. Thus far, a financial catastrophe has been averted, which was the initial goal of policymakers. [...] But, at the same time, those policies have seriously — and unnecessarily — injured the economic well-being of other sectors of the U.S. economy, agriculture and manufacturing in particular."

xxxvii. "The Third World debt crisis with the commercial banks has hindered Latin American growth and it has restricted U.S. exports to this region. The effects of the Latin American debt crisis on U.S. trade have been particularly distressing from the perspective of U.S. farmers and manufacturing industries."

xxxviii. "Let's say you run a hardware store in Fairmont, Minnesota. Most of your customers are farmers. What will happen to your business as the farm credit crisis deepens? If your customers use more and more of their earnings just to pay the interest on their loans, they are going to cut purchases in your store. You'll be lucky to stay in business. [...]

The U.S. is similar to the hardware store in Fairmont. And Latin America is the customer in deep trouble. The nations of Latin America are our natural growth partners; they are our neighbors. One of the hopes we have for our children to enjoy the same kind of economic growth we had after World War II is to help those neighbors prosper. Prosperous customers make for a prosperous store."

xxxix. "Over the last 5 years Latin America has been obliged to transfer to foreign creditors US\$ 132 billion. This resource transfer not only inhibits growth obviously in the developing countries but also shrinks U.S. export markets. Moreover, to generate foreign exchange to make interest payments, debt-ridden nations must run large trade surpluses.”

xl. "Every dollar shipped to money center banks is one dollar less to spend on wheat grown in Iowa or trucks made in Michigan. I would argue, Senator, that the current allocation of the debt burden does not respond to our long-term national interests. It places the interest of the banks above the interests of our export-oriented manufacturers and farmers."

xli. "Existing ways of dealing with the Latin American debt problem - from the Baker Plan, the International Monetary Fund and the World Bank - only aggravate the problem. By loaning the indebted countries even more money, they have encouraged increased exports to generate 
capital to service debts to the money center U.S. banks. Latin America's forced increased exports decrease our farmers' exports and lead to continous cycle of falling commodity prices world-wide."

xlii. "It seems very strange indeed that there are such different rules for the rural banks and the large, multinational banks. Rural Kansas banks would find it difficult to survive if their response to farmers who could not pay their loans was to lean them even more money they could not repay. [...] Rather, rural Kansas banks find it necessary to renegotiate those troubled loans, to find a way for the farmer to reduce, rather than increase debt. [...]

It seems logical to me that the large multinational banks should respond to debtor nations in a similar way; however, their response seems to be to throw good money after bad, increasing the debt and the banks' profits along the way, but almost guaranteeing that the cycle of falling commodity prices and social and political turmoil in the debtor nations will continue. The livelihoods of the Kansas farmer and the Latin American campesino alike are being abridged by policies which are counter-productive to democratic and economic development in Latin America."

xliii. "Besides reducing the imports of U.S. farm commodities, Latin American debtors have significantly stepped up exports of agricultural commodities to the U.S. and Third World country markets. [...] In 1979 the United States accounted for 41 percent of all the soybean meal exports, while Brazil and Argentina combined had a 32 percent share [...] By 1985, Brazil and Argentina had 47 percent of the world market while we had less than 25 percent."

xliv. "While U.S. industries and citizens of Latin America have paid a tremendous cost, effectively financing the activities of the elites and the international banks, the banks themselves have thus far emerged relatively unscathed".

xlv. "I think the substantive parts of the Baker plan are very much like supply side economics. In the United States we have experience with that and we still have it in our budget deficits. It simply will not work. [...] Growth has been negative. The Baker plan has served primarily for a reduction of exposure on the part of commercial banks."

xlvi. "The current debt strategy does not resolve that issue. I doubt that any strategy that doesn't include some form of debt relief can. By that I mean, as you have suggested, a reduction in the banks' claims and passing on the benefits of reduction in those claims which both reduces the outstanding debt and the debt servicing burden, a write-down by the banks and the passing on of those benefits, of the discounts, to the debtor countries."

xlvii. "No improvement in the debt/trade equation that destabilizes the U.S. banking system would be in the national interest; but there is some room for maneuver. The commercial banks are in a better position today than when the debt crisis hit in 1982 and could absorb a higher proportion of the costs of their past mistakes."

xlviii. "The United States needs to modernize regulatory practices. [...] The emerging secondary market for debt is for converting commercial bank loans into a variety of new instruments that look more like securities than loans and can be traded more freely. We need to create a regulatory regime for the secondary market in order for it to develop. [...] The regulatory structure that governs the commercial banks' portfolio of Third World debt focuses almost exclusively on loans. The set of institutions that currently governs commercial lending has inhibited the transformation of these loans into more liquid assets."

xlix. "The right policies in developing countries are essential. There is no solution without this. Any suggestion that political negotiations or new institutions or any other formula, no matter how interesting it may seem in the abstract, can relieve countries of the necessity to follow good 
policies is counterproductive. Any solution to the debt problem must be designed to promote improved policies."

1. "KENNEDY: You think that the situation is in good shape at the moment?

MULFORD: I didn't say the situation was in good shape, but given...

KENNEDY: Your strategy is working well.

MULFORD: ... but given the complexity of the situation I think our strategy is working well.

KENNEDY: This discussion is getting complicated.

MULFORD: I see no other plan, Mr. Kennedy, on the table that is acceptable to all the parties under which they are prepared to operate and they are prepared to operate under the present debt strategy and are doing so.

KENNEDY: But by the definition of the parties you are including not the Third World countries and the million jobs that have been displaced here. What we are really talking about is the interest of the banks; is that correct?

MULFORD: No, we are talking about all the parties, that is to say the debtor countries themselves $[\ldots]$, the international financial institutions and the commercial banks."

li. "I have assumed, rightly or wrongly, that that is not a very practical approach, that the United States and other parliaments were not going to provide the kind of public backing or direct public funds.

I also think you have another really more broadly philosophical problem of whether it is necessary or desirable to write down these loans and whether that is a good move as a general matter in terms of international financial markets moving ahead, a good move in terms of the growth and prosperity of the borrowing countries themselves that I think are going to be dependent upon access to capital from abroad not just now but in the long run. Do you really facilitate that by this kind of arrangement that involves a kind of forced write-down or semiforced write-down of the loans? We have not thought that that's very helpful."

lii. "I don't think I agree with the observation as a general matter, but to the degree that regional banks refuse to participate in these packages they may bring about that result."

liii. "Administration policy is imposing the burden of the consequences of that Third World debt overhang on the sectors of the society not related to the financial community, namely manufacturing and agriculture".

liv. 'I don't see any possibility of this committee, or the House for the matter, approving the general capital increase as long as this impasse on Third World debt remains".

lv. "The Secretary of the Treasury shall instruct the United States Executive Director of the International Bank for Reconstruction and Development to initiate discussions with other directors of such a bank and to advocate and support the facilitation of voluntary market-based programs for reduction of sovereign debt".

lvi. "At a time of competing demands and budget constraints, the case for additional quota resources must be compelling. [...] There should be a [...] demonstrated need for funds, not simply a presumption that more is better."

lvii. "In an ironic and worrying way, the [...] commercial bank financing process has been weakened in part because bank exposures have been reduced so dramatically".

1viii. "To avoid that, we need a strong reaffirmation of the commitment of the creditor banks to the bigger picture." 
lix. "In the year 1988, after 3 years of experience with the Baker plan, the facts and figures were beginning to come in. There were some patterns that were clearly rather troubling.

One was that the commercial banks were clearly in a process of withdrawing. [...] They recognized in general that they were not going to be fully paid out on the debt, and they did not wish to put in additional new moneys. [...]

Second, it was clear that as the banks withdrew, the exposure of the international institutions, and to the member governments through those institutions, was rising very sharply. There was implicit in that process a transfer of risk to official institutions, if it had gone unchecked, it clearly would ultimately have resulted in practically the whole of the stock of debt gradually being shifted to the official side. That was something we felt was innaceptable.

Third, it was clear by 1988, and I don't think it was clear before that, that there were differentiation in the banking community and attention to markets that made it possible to think in terms of market solutions to some of these problems. [...] In other words, [...] perhaps debt reduction, if it was accomplished on a voluntary basis, could coexist with the continued provision of new money in some form."

1x. "The problem with a debt-equity swap is that it is highly inflationary, exactly in the circumstances in which the government is desperately attempting to control inflation. In the short term the budgetary burden of the debt-equity swap is several times the burden of interest payments on the debt, at a time when the interest payments are already unmanageably high.

Consider an illustration with Brazil, whose debt-equity program was a major contributor to a hyperinflation which is now destabilizing the economy and the society. Suppose that $\$ 1$ billion of debt is converted in a debt-equity swap. Without the debt-equity swap, the $\$ 1$ billion of debt would have a cash-flow burden to the Brazilian government of about $\$ 100$ million. Alternatively, suppose that the government repurchases the debt in a swap using cruzados. The secondary market price of $\$ 1$ billion of Brazilian debt would be about $\$ 400$ million, i.e. a $\$ 600$ million discount relative to face value. In a typical debt-equity swap, Brazil might capture about half the discount, or in other words pay about $\$ 700$ million in Cruzados for the $\$ 1$ billion of face value of debt. Thus the current cash cost of the debt has risen from $\$ 100$ million to $\$ 700$ million!

In order to avoid the inflationary consequences of a $\$ 700$ million surge in the money supply, the Brazilian government might sell government notes (called OTN's) to soak up the $\$ 700$ million of new Cruzado money. In this case, the internal debt would rise by about $\$ 700$ million. Since the OTN's now carry a real interest rate of about 20 percent or more per year, the interest payments on the OTN's would amount to about $\$ 140$ million per year. Thus, while the external debt of Brazil goes down, the overall cost of servicing to the government in fact goes up."

1xi. "The goal of the Brady plan is to shut up Schumer and Bradley. [...] And it's worked like a charm."

1xii. "A facility is something that many people on this side have supported. [However,] I'm not wed to a facility [and] I don't think we have to be."

lxiii. "I am basically pleased to note that the administration has decided to place its emphasis on debt reduction rather debt collection, a fact that helps temper my disappointment, quite frankly, that the Treasury has chosen to reject the debt management authority, which the Congress had proposed.

If an alternative proposal can achieve the desired results, I think as Mr. Schumer indicated, we of course are not wedded to any specific mechanism." 
1xiv. "It is clear from the testimony this morning and from all the general confusion about this that the details have not been spelled out yet., and I will try to emphasize a few of the areas where I think more thinking has to be done".

lxv. "Market forces don't work in a situation where it is in every individual creditors' interest to let every other creditor do whatever they want, but that particular bank has the incentive to hold on to its debt. We have the classic kind of free rider problem which overwhelms any meaningful extensive debt reduction. And I have been with executives at Citibank who told me six months ago, 'Well, we are all in favor of debt reduction. We are not going to give it. We are sure some other banks are going to give it'."

1xvi. "If nothing else, a plan that requires $\$ 25$ billion of multilateral resources to support $\$ 70$ billion of debt reduction seems to represent an awfully expensive way of buying debt relief from the banks, even if the stated intention is to protect the creditor country taxpayers. [...]

If the Bretton Woods institutions do not limit the use of their funds to guarantee interest payments only for debts of those countries whose obligations to the banks have been reduced to a level so that the remaining debts can be fully serviced, these international institutions will become the indirect conduit for a taxpayer bailout of the banks."

1xvii. "As I mentioned before, I just came from a C-Span call-in program and the questions about the Brady Plan were very hostile. Several times people asked 'why should the American taxpayer be saddled with the obligations of Third World debt?'. I think that is a pretty good question. I thought maybe I could try it on you."

lxviii. "American taxpayers have been called upon to support those international organizations for 40 years. That is because such support - and I think this has been a bipartisan consensus for over four decades - is in the United States interest, and it is in our strategic and security interest. [...] But beyond that it is important to recognize the economic benefits, both direct and indirect, from our support of the multilateral organizations." 